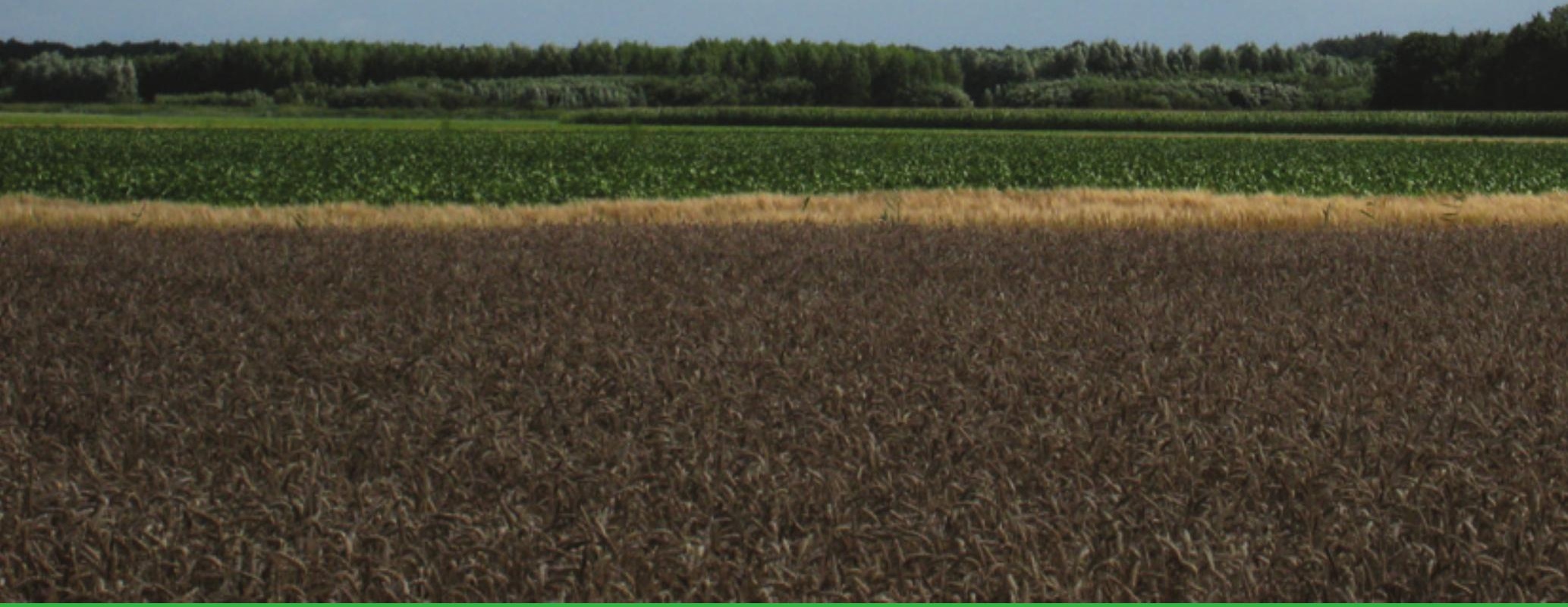

\title{
Veeljarige fosfaatveldproeven op gras- en bouwland
}

Syntheserapport

Phillip Ehlert, Jantine van Middelkoop, Willem van Geel, Janjo de Haan en Inge Regelink 



\title{
Veeljarige fosfaatveldproeven op gras- en bouwland
}

Syntheserapport

Phillip Ehlert ${ }^{1}$, Jantine van Middelkoop ${ }^{2}$, Willem van Geel $^{3}$, Janjo de Haan ${ }^{3}$ en Inge Regelink ${ }^{1}$

\author{
1 Wageningen Environmental Research \\ 2 Wageningen Livestock Research \\ 3 Wageningen Plant Research
}

Dr. G.L. Velthof, senior onderzoeker bij Wageningen Environmental Research heeft de review uitgevoerd en is akkoord met publicatie.

Dit onderzoek is uitgevoerd door Wageningen Environmental Research in opdracht van en gefinancierd door het ministerie van Landbouw, Natuur en Voedselkwaliteit, in het kader van het Beleidsondersteunend onderzoekthema 'Mest, milieu en klimaat' (projectnummer BO-43-012.02-001).

Wageningen Environmental Research

Wageningen, oktober 2018

Rapport 2906

ISSN 1566-7197 
Phillip Ehlert, Jantine van Middelkoop, Inge Regelink, Janjo de Haan en Willem van Geel, 2018. Veeljarige fosfaatveldproeven op gras- en bouwland; Syntheserapport. Wageningen, Wageningen Environmental Research, Rapport 2906. 114 blz.; 45 fig.; 26 tab.; 70 ref.

In acht veeljarige veldproeven op grasland en bouwland worden de effecten van verschillende vormen van fosfaatmanagement (giften en typen meststof) op opbrengst en kwaliteit, fosfaattoestand van de bodem en fosfaatuitspoeling onderzocht. De veldproeven op bouwland werden in 1972 of in 1986 aangelegd, op grasland in 1997. Dit rapport geeft een synthese van de resultaten 2000-2016. Uit de resultaten uit de periode 2000-2016 volgt dat evenwichtsbemesting op opbrengst en gewaskwaliteit vooral een effect heeft op de opbrengst van fosfaatbehoeftige gewassen, zoals aardappel (gewasgroep 1). Voor fosfaatbehoeftige gewassen wordt een opbrengstderving van $4 \%$ vastgesteld t.o.v. ruimere fosfaatbemestingen. Voor minder fosfaatbehoeftige gewassen (gewasgroep 2) is dat $1 \%$. Bij grasland wordt van meet af aan bij zandgrond en veengrond een $6 \%$ lagere opbrengst gevonden bij evenwichtsbemesting t.o.v. hogere fosfaatoverschotten, maar bij kleigrond werden vergelijkbare opbrengsten vastgesteld. Dit verschil wijzigt niet in de periode 20002016.

Evenwichtsbemesting komt als eerste tot uitdrukking in wijzigingen in de fosfaattoestand van de bodem zoals ze gemeten worden met standaardbodemtesten ( $\mathrm{P}-\mathrm{CaCl}_{2}, \mathrm{Pw}$-getal of P-Al-getal). Veranderingen in de fosfaattoestand verlopen traag. Op bouwland stelt na zo'n 10 jaar een evenwicht in, gegeven het jaarlijkse fosfaatoverschot. Op grasland werd bij evenwichtsbemesting op zandgrond een daling van het P-Al-getal vastgesteld, maar geen wijziging in het P-Al-getal bij kleigrond. Op veengrond varieerde het $\mathrm{P}$-Al-getal te veel om hieruit een trend te kunnen afleiden.

Uit metingen van fosfaat in het bodemvocht op verschillende diepten blijkt dat bij grasland vooral de bodemlaag 0-5 cm reageerde op verschillen in fosfaatoverschotten op klei- en veengrond, maar niet bij zandgrond. Hogere overschotten leidden tot hogere fosfaatconcentraties. Op bouwland werd alleen op een van de kleigronden een effect van opgelegde fosfaatbehandelingen vastgesteld; hogere fosfaatoverschotten leidden tot hogere concentraties in de bodem op $35 \mathrm{~cm}$ diepte. Op een andere kleigrond en een zandgrond werden op deze diepte geen effecten vastgesteld door verschillen in fosfaatoverschotten. De veranderingen in de fosfaattoestand en -uitspoeling na instelling van fosfaatevenwichtsbemesting verlopen traag en evenwichtssituaties van de fosfaattoestand in de bodem tussen verschillende fosfaatbodemfracties zijn nog niet bereikt.

Trefwoorden: Fosfaat, grasland, bouwland, evenwichtsbemesting, fosfaatgebruiksnorm, opbrengst, kwaliteit, grondonderzoek, uitspoeling

Phillip Ehlert, Jantine van Middelkoop, Inge Regelink, Janjo de Haan and Willem van Geel, 2018. Long term phosphate field trials on grassland and arable land. Synthesis report; Wageningen, Wageningen Environmental Research, Report 2906. 114 pages; 45 fig.; 26 tab.; 70 ref.

In eight long term field trials on grassland and arable land, the effects of different forms of phosphate management (application rates and fertilising products) on yield and quality, phosphate status of the soil and phosphate leaching are investigated. The field trials on arable land started in 1972 or in 1986 , on grassland in 1997. This report gives a synthesis of the results 2000-2016.

Results of the period 2000-2016 show that the effect of equilibrium fertilisation on yield and crop quality is mainly found for crops with a known high phosphate requirement (crop group 1). For these crops, a yield loss of $4 \%$ is found with regard to higher phosphate application rates. The yield loss is $1 \%$ for crops with a lower phosphorus requirement (crop group 2). In the case of grassland a $6 \%$ lower yield is found for sandy soil and peat soil from the outset for equilibrium fertilisation compared to treatments with higher phosphate surpluses, but similar yields were observed for clay soil. This difference does not change in the period 2000-2016.

Equilibrium fertilisation leads to changes in the phosphate status of the soil as measured by standard soil tests for phosphorus ( $\mathrm{P}-\mathrm{CaCl}_{2}, \mathrm{Pw}$-value or $\mathrm{P}$-Al-value). Changes in phosphate status in time are slow. On arable land a balance between application rate and soil $\mathrm{P}$ status is set after about 10 years given the annual phosphate surplus. On grassland, a decrease in the P-Al value was observed for equilibrium fertilisation on sandy soil but no change in clay soil. On peat soil, the P-Al value varied too much in order to derive a trend over time. 
Measurements of phosphate in the soil moisture at different depths show that in grassland the soil layer $0-5 \mathrm{~cm}$ reacted to differences in phosphate surpluses in clay and peat soil but not in sandy soil. Higher surpluses led to higher concentrations. On arable land, an effect of imposed phosphate treatments was only observed for one of the clay soils; higher phosphate surpluses led to higher concentrations in the soil at $35 \mathrm{~cm}$ depth. In the case of another clay soil and a sandy soil, no effects were found at this depth despite large differences in phosphate surpluses.

The changes in the phosphate status and leaching of phosphorus after implementation of phosphate equilibrium fertilisation are slow and the phosphate status after implementation of equilibrium fertilisation in the soil has not reached yet an equilibrium between different soil fractions fractions.

Keywords: phosphate, grassland, arable land, equilibrium fertilisation, phosphate application standard, yield, quality, soil research, leaching

Dit rapport is gratis te downloaden van https://doi.org/10.18174/460816 of op www.wur.nl/environmental-research (ga naar 'Wageningen Environmental Research' in de grijze balk onderaan). Wageningen Environmental Research verstrekt geen gedrukte exemplaren van rapporten.

(2) 2018 Wageningen Environmental Research (instituut binnen de rechtspersoon Stichting Wageningen Research), Postbus 47, 6700 AA Wageningen, T 03174807 00, www.wur.nl/environmental-research. Wageningen Environmental Research is onderdeel van Wageningen University \& Research.

- Overname, verveelvoudiging of openbaarmaking van deze uitgave is toegestaan mits met duidelijke bronvermelding.

- Overname, verveelvoudiging of openbaarmaking is niet toegestaan voor commerciële doeleinden en/of geldelijk gewin.

- Overname, verveelvoudiging of openbaarmaking is niet toegestaan voor die gedeelten van deze uitgave waarvan duidelijk is dat de auteursrechten liggen bij derden en/of zijn voorbehouden.

Wageningen Environmental Research aanvaardt geen aansprakelijkheid voor eventuele schade voortvloeiend uit het gebruik van de resultaten van dit onderzoek of de toepassing van de adviezen.

Wageningen Environmental Research Rapport 2906 | ISSN 1566-7197

Foto omslag: @ Wageningen Environmental Research 



\section{Inhoud}

$\begin{array}{ll}\text { Samenvatting } & 7\end{array}$

$\begin{array}{ll}\text { Beleidssamenvatting } & 11\end{array}$

$\begin{array}{lll}1 & \text { Inleiding } & 15\end{array}$

$\begin{array}{lll}1.1 & \text { Aanleiding } & 15\end{array}$

$\begin{array}{lll}1.2 & \text { Kennisbehoefte } & 16\end{array}$

$\begin{array}{lll}1.3 & \text { Vraagarticulatie voortkomend uit de kennisbehoefte } & 17\end{array}$

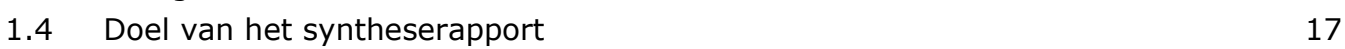

$\begin{array}{ll}\text { Opzet en uitvoering } & 18\end{array}$

$\begin{array}{lll}2.1 & \text { Veldproeven op grasland } & 18\end{array}$

2.1.1 Opzet 18

$\begin{array}{ll}2.1 .2 \text { Monitoring gewas, bodem en bodemvocht } & 19\end{array}$

$\begin{array}{ll}2.2 \text { Veldproeven op bouwland } & 20\end{array}$

2.2.1 Opzet 20

2.2.2 Monitoring gewas, bodem en bodemvocht 23

2.2.3 Bodemvocht 24

2.2.4 Chemisch grond- en gewasonderzoek $\quad 24$

2.2 .5 Bewerking 24

$3 \quad$ Resultaten grasproef $\quad 26$

3.1 Gewasopbrengst 26

$\begin{array}{lll}3.2 & \text { Gewaskwaliteit } & 27\end{array}$

3.2.1 Fosforgehalte $\quad 27$

$\begin{array}{ll}3.2 .2 \text { Voederwaarde } & 29\end{array}$

$\begin{array}{lll}3.3 & \text { Fosfaatbalans, aanvoer en afvoer } & 30\end{array}$

$\begin{array}{lll}3.4 & \text { Bodem } & 35\end{array}$

3.4.1 Standaard bodemtesten $\quad 35$

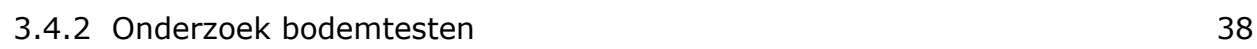

3.4.3 Verdeling van fosfaat over fosfaatfracties $\quad 42$

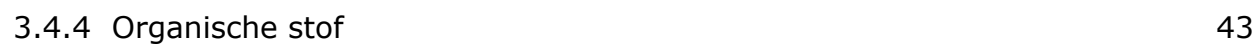

3.4.5 Uitmijnen van fosfaat (geen fosfaatbemesting) 44

3.5 Bodemvocht 45

3.5.1 Fosfaatconcentraties in het bodemvocht bij evenwichts- en
overschotbemesting

3.5.2 Uitspoelingsverliezen bij evenwichts- en overschotbemesting 48

3.6 Landbouwkundig en bodemkundig perspectief 50

$\begin{array}{ll}\text { 3.6.1 Landbouwkundig perspectief } & 50\end{array}$

3.6.2 Bodemvruchtbaarheid bij evenwichtsbemesting 54

3.6.3 Effecten op fosfaatuitspoeling $\quad 55$

$4 \quad$ Resultaten Bouwlandproeven $\quad 56$

4.1 Gewasopbrengsten $\quad 56$

4.1.1 Lelystad (Fosfaattoestandenproef) 56

4.1.2 Marknesse (fosfaathoeveelhedenproef) 58

4.1.1 Marknesse (fosfaattoestandenproef) 60

$\begin{array}{ll}\text { 4.1.2 Wijster (fosfaathoeveelhedenproef) } & 60\end{array}$ 
4.2 Fosfaatgehalten, fosfaataanvoer en -overschot 62

4.2.1 Lelystad (fosfaattoestandenproef) $\quad 62$

4.2.2 Marknesse (fosfaathoeveelhedenproef) 64

4.2.3 Wijster (fosfaathoeveelhedenproef) 66

$\begin{array}{lll}4.3 & \text { Bodem } & 70\end{array}$

4.3.1 Standaardbodemtesten en effect van fosfaatbalans $\quad 70$

$\begin{array}{ll}\text { 4.3.2 Andere bodemtesten } & 78\end{array}$

$\begin{array}{ll}\text { 4.3.3 Organische stof } & 87\end{array}$

4.3.4 Uitmijnen van fosfaat $\quad 89$

4.4 Landbouwkundig en bodemkundig perspectief 90

4.4.1 Fosfaatafvoer in gewasrotatie 90

4.4.2 Bodemvruchtbaarheid bij evenwichtsbemesting 93

4.5 Bodemvocht $\quad 94$

4.6 Antwoorden op de vragen $\quad 96$

4.6.1 Leidt toepassing van een gebruiksnorm voor fosfaat, afgestemd op evenwichtsbemesting, tot een afname van de gewasopbrengst en kwaliteit en is er een moment waarop deze afname stabiliseert?

4.6.2 Leidt een veeljarige toepassing van een gebruiksnorm voor fosfaat, afgestemd op evenwichtsbemesting, tot een vermindering van de fosfaatbeschikbaarheid of het organische-stofgehalte?

4.6.3 Leidt een veeljarige toepassing van een gebruiksnorm voor fosfaat, afgestemd op evenwichtsbemesting, tot een vermindering van de fosfaatuitspoeling?

$\begin{array}{lll}5.1 & \text { Inleiding } & 99\end{array}$

5.2 Toepassing van kennis uit proeven in andere projecten 99

5.3 Toekomstige bijdrage van dit onderzoek aan beantwoording kennisvragen 100

$\begin{array}{ll}\text { 5.3.1 Proeven lopen vooruit op praktijk } & 100\end{array}$

5.3.2 Beantwoording van vragen door verdere analyse van reeds beschikbare $\begin{array}{ll}\text { data } & 101\end{array}$

5.3.3 Beantwoording van vragen door voortzetting van de veldproeven 101

5.3.4 Wat kunnen de onderzoeksresultaten bijdragen aan de KRW-opgave? 103

\section{$\begin{array}{ll}\text { Literatuur } & 106\end{array}$}

Bijlage 1 Toepassing van kennis uit proeven in andere projecten 111 


\section{Samenvatting}

Dit syntheserapport geeft een overzicht van resultaten verkregen met veeljarige fosfaatveldproeven op gras- en bouwland. De veldproeven dienen de beantwoording van drie vragen:

1. Leidt toepassing van een gebruiksnorm voor fosfaat, afgestemd op evenwichtsbemesting, tot een afname van de gewasopbrengst en -kwaliteit en is er een moment waarop deze afname stabiliseert?

2. Leidt een veeljarige toepassing van een gebruiksnorm voor fosfaat afgestemd op evenwichtsbemesting tot een vermindering van de fosfaatbeschikbaarheid of het organischestofgehalte? Hierbij werden twee subvragen geformuleerd.

a. Daalt de voor het gewas beschikbare bodemvoorraad fosfaat?

b. Daalt door toepassing van fosfaatgebruiksnorm het organische-stofgehalte van de bodem?

3. Leidt een veeljarige toepassing van een gebruiksnorm voor fosfaat, afgestemd op evenwichtsbemesting, tot een vermindering van de fosfaatuitspoeling?

Bij de beantwoording van deze drie vragen wordt onderscheid aangebracht tussen de resultaten verkregen met de veldproeven op grasland en die verkregen voor bouwland.

\section{Grasland}

In 1997 zijn er proeven aangelegd op zand-, klei- en veengrond op vier locaties (Heino (zand), Soerendonk (zand), Lelystad (klei), Zegveld (veen)). Er zijn drie fosfaatbehandelingen (0, 20 en $40 \mathrm{~kg}$ $\mathrm{P}_{2} \mathrm{O}_{5}$ /ha overschot) gecombineerd met twee stikstofbehandelingen (180 en $300 \mathrm{~kg} \mathrm{~N} /$ ha overschot). Omdat de huidige focus in de veldproef ligt op effecten van fosfaatbemesting $(P)$, zijn de resultaten van de twee stikstofbehandelingen $(\mathrm{N})$ veelal gemiddeld. De percelen worden gemaaid, beweid en bemest met runderdrijfmest en superfosfaat (alleen bij behandelingen met overschotbemesting). Sinds 2001 is de proef uitgebreid met uitmijnvelden waar géén fosfaat wordt aangevoerd. Jaarlijks worden o.a. de gewasopbrengst, fosfaatafvoer en de fosfaattoestand in de bodem gemonitord. Tot 2011 werd de fosfaatconcentratie in het bodemvocht bepaald. De proef op Zegveld en Lelystad wordt nog altijd gecontinueerd, maar op Heino en Soerendonk is de proef reeds afgesloten.

Bij evenwichtsbemesting wordt beoogd om de fosfaataanvoer gelijk te stellen aan de fosfaatafvoer via gras. De daadwerkelijk gerealiseerde P-overschotten op de vier locaties variëren tussen $-9 \mathrm{~kg} \mathrm{P}_{2} \mathrm{O}_{5} / \mathrm{ha}$ en $7 \mathrm{~kg} \mathrm{P}_{2} \mathrm{O}_{5} /$ ha per jaar. Deze verschillen ten opzichte van het beoogde P-overschot ontstaan door jaarlijkse variatie in gewasopbrengst en variatie in de samenstelling van drijfmest. De totale fosfaataanvoer bij evenwichtsbemesting (vanuit bemesting en beweiding) bedraagt 77 tot $93 \mathrm{~kg}$ $\mathrm{P}_{2} \mathrm{O}_{5} /$ ha en is in overeenstemming met de huidige gebruiksnorm bij fosfaattoestand neutraal (90 kg $\mathrm{P}_{2} \mathrm{O}_{5} /$ ha).

Evenwichtsbemesting leidt op zand- en veengrond tot gemiddeld $6 \%$ opbrengstderving in vergelijking met overschotbemesting. Deze derving werd vanaf het begin van de aanleg van de grasproef vastgesteld, maar pas na circa acht jaar werd dit verschil significant. Er was geen sprake van een toename in opbrengstderving in de loop van de tijd. Fosfaatgehalten in het gras zijn circa 6\% (kleigrond) en $10 \%$ (zand- en veengrond) lager bij evenwichtsbemesting in vergelijking met overschotbemesting. Dit verschil was eveneens vanaf het begin aanwezig. Indien de resultaten van het gewasonderzoek gespiegeld worden aan voedernormen is er gemiddeld genomen net voldoende $\mathrm{P}$ in het gras aanwezig om zowel bij beweiding als stalvoedering op de voedernorm te kunnen voeren. Er zullen echter ook jaren zijn dat het melkvee niet voldoende P opneemt bij evenwichtsbemesting, maar dit hangt mede af van het aandeel snijmaïs. Bij een gematigder aandeel snijmaïs in het rantsoen $(32 \%)$ is er gemiddeld gesproken nog geen gevaar voor een te lage P-opname. Evenwichtsbemesting heeft geen negatief effect op de voederwaarde van het gras (VEM, DVE, OEB). 
Bij aanvang bevonden de proefpercelen zich in fosfaattoestand 'neutraal' (conform het P-Al-getal en beoordeling voor de fosfaatgebruiksnormen). Op zandgronden resulteert evenwichtsbemesting in een significante daling van het P-Al-getal, terwijl er op klei- en veengrond geen aanwijzingen zijn voor een dalende trend. Bij evenwichtsbemesting op zandgronden daalt het P-Al-getal in vijftien jaar met 5-15 eenheden waardoor de fosfaattoestand kan veranderen van neutraal naar laag. Hierbij bedroeg de gemiddelde fosfaataanvoer $81-88 \mathrm{~kg} \mathrm{P}_{2} \mathrm{O}_{5} / \mathrm{ha}$. Om het P-Al-getal op zandgronden te handhaven, is een overschot van circa 20-40 kg $\mathrm{P}_{2} \mathrm{O}_{5}$ /ha nodig. Op zeekleigrond (Lelystad) blijft het P-Al-getal bij evenwichtsbemesting gehandhaafd, wat deels te verklaren is door bodemvormende processen welke specifiek zijn voor jonge kleigronden (o.a. opname van fosfaat uit diepere lagen). Deze resultaten kunnen zodoende niet vertaald worden naar bijvoorbeeld de veel oudere rivierkleigronden. Op veengrond (Zegveld) vertoont het $\mathrm{P}$-Al-getal een zeer sterke temporele variatie waardoor het niet mogelijk is om een verloop in de tijd vast te stellen. Ook $\mathrm{P}-\mathrm{CaCl}_{2}$-concentraties zijn lager bij evenwichtsbemesting dan bij overschotbemesting, al zijn deze verschillen veelal niet statistisch significant door de grote temporele variatie in $\mathrm{P}-\mathrm{CaCl}_{2}$. Het organische-stofgehalte in de wortelzone blijft op peil wanneer evenwichtsbemesting wordt uitgevoerd met runderdrijfmest.

De geconstateerde daling in het P-Al-getal duidt op een afname van de fosfaatbeschikbaarheid bij evenwichtsbemesting. Om beter inzicht te verkrijgen in de achterliggende bodemchemische processen, is het verloop in bodemparameters voor fosfaat (P-totaal, P-oxalaat, organisch-P) geanalyseerd. Hieruit blijkt dat het totale fosfaatgehalte in de bodem nagenoeg gelijk blijft, maar dat de verdeling van fosfaat over de diverse fosfaatfracties in de tijd verandert. Op alle grondsoorten neem het P-oxalaatgehalte, een maat voor de hoeveelheid fosfaat gebonden aan minerale bodemdeeltjes, gedurende de looptijd van de veldproeven met $15-30 \%$ af. Er is vooralsnog geen sprake van een nieuwe evenwichtssituatie en er wordt verwacht dat het $\mathrm{P}$-oxalaatgehalte nog verder zal dalen. Er zijn aanwijzingen dat de afname in P-oxalaat gepaard gaat met vastlegging van fosfaat in organisch fosfaat en/of zeer stabiele fosfaatmineralen welke beperkt of niet beschikbaar zijn voor gewassen. Er is echter onzekerheid over de vorm(en) waarin fosfaat wordt vastgelegd en de termijn waarop omzetting van gewas-beschikbaar fosfaat in organisch fosfaat en/of zeer stabiele fosfaatmineralen leidt tot een daling in de gewasopbrengsten.

Effecten van evenwichtsbemesting op fosfaatuitspoeling zijn bepaald door monitoring van fosfaatconcentraties in het bodemvocht. Deze fosfaatconcentraties vertonen een zeer sterke temporele variatie waar geen trend in de tijd kan worden vastgesteld. Wel kunnen de gemiddelde fosfaatconcentraties (1997-2011) bij evenwichtsbemesting vergeleken worden met die bij overschotbemesting. Hieruit blijkt dat evenwichtsbemesting op klei- en veengrond ten opzichte van behandelingen met fosfaatoverschot leidt tot lagere fosfaatconcentraties in de bovenste vijf $\mathrm{cm}$ van de bodem, terwijl op zandgrond geen verschil werd gevonden. Echter, aan de onderzijde van de graszode (20-30 cm diepte) zijn fosfaatconcentraties in het bodemvocht bij evenwichtsbemesting gelijk aan die bij overschotbemesting. Dit betekent dat de uitspoeling van fosfaat vanuit de graszode bij evenwichtsbemesting tijdens de duur van het hier gerapporteerde onderzoek (2000-2016) gelijk zal zijn aan die bij overschotbemesting. Uitsluitend op veengrond waar sprake is van een overwegend laterale uitspoeling uit de bovenste $10 \mathrm{~cm}$ van de bodem, is de fosfaatuitspoeling bij evenwichtsbemesting lager dan bij overschotbemesting. Op alle grondsoorten spoelt fosfaat hoofdzakelijk uit in de vorm van organisch en/of colloïdaal fosfaat. Deze bevinding wordt geconditioneerd door de methode (centrifuge) van bemonstering van bodemvocht.

De grasproef kent beweiding. De uitscheiding van $\mathrm{P}$ in de vorm mestflatten leidt tot een heterogene fosfaatverdeling over het perceel. Er kan beredeneerd worden dat dit leidt tot een lagere P-benutting en een hoger risico op P-uitspoeling in vergelijking met percelen waar homogeen wordt bemest (i.e. geen beweiding). Dit effect wordt groter naarmate er tijdens het groeiseizoen meer dagen, meer uren per dag of met meer dieren wordt beweid. Het risico voor afspoeling van $\mathrm{P}$ neemt daardoor toe.

Bij langdurig uitmijnen - gestart bij fosfaatklasse neutraal - (géén fosfaataanvoer) vindt na circa acht jaar (waarbij de fosfaattoestand gedaald was tot klasse laag) een sterke daling in de opbrengst plaats. Uitmijnen resulteert in een daling van het P-Al-getal en fosfaatconcentraties in het bodemvocht, maar deze veranderingen beperken zich tot de bovenste $10 \mathrm{~cm}$ van de bodem waardoor de uitspoeling vanuit 
de wortelzone $(20-30 \mathrm{~cm})$ niet of nauwelijks afneemt. Het ploegen van de bodem kan in deze situatie gunstig zijn om ook fosfaat uit onderliggende bodemlagen beschikbaar te maken voor plantopname.

\section{Bouwland}

Er zijn vier bouwlandproeven aangelegd, waarvan drie op zavelgrond (Lelystad, Marknesse) en één op zandgrond (Wijster) met ieder een eigen proefopzet. De vier proeven kennen een lange historie $(1972,1986)$ waardoor er een breed bereik van fosfaattoestanden is ontstaan. Hierdoor zijn deze proeflocaties uitermate geschikt voor het testen van gewaseffecten als functie van fosfaatbemesting en fosfaattoestand.

Akkerbouwgewassen en vollegrondsgroenten reageren op fosfaatbemesting en de fosfaattoestand van de bodem, al is de gewasreactie op fosfaatbemesting doorgaans beperkter dan bijvoorbeeld die op stikstofbemesting. Uitmijnen bij een fosfaatklasse neutraal, waarbij géén fosfaatbemesting wordt toegepast, leidde in de periode 2005-2016 tot opbrengstderving. Zonder fosfaatbemesting bij zeer lage fosfaattoestand werden opbrengstdervingen tot circa $26 \%$ vastgesteld, afhankelijk van het gewas en grondsoort. Bij een voldoende of neutrale fosfaattoestand zijn de vastgestelde opbrengstdervingen bij evenwichtsbemesting beperkt of ontbreken.

Bij percelen met fosfaatbemesting zijn de verschillen in gewasopbrengst tussen fosfaatgiften en/of fosfaattoestand relatief klein. Door de proefopzet gaan hogere fosfaatgiften veelal samen met een hogere fosfaattoestand waardoor deze twee parameters verstrengeld zijn.

Op zandgrond van Wijster is de gewasreactie op fosfaatbemesting en fosfaattoestand groter dan op zavelgrond van Lelystad of Markenesse. Dit effect wordt veroorzaakt doordat de zandgrond van Wijster armer is aan direct gewas-beschikbaar fosfaat dan de zavellocaties.

De opbrengstderving door fosfaattekort op de zavelgronden is het grootst bij gewassen van gewasgroep 1 (aardappel, zaaiui) en neemt af bij gewasgroep 2 (suikerbiet) en de daaropvolgende gewasgroepen 3 (zomergerst, peen op klei) en 4 (tarwe). Gewasgroep 1 betreft gewassen met de hoogste fosfaatbehoefte en gewasgroep 4 die met de laagste, conform de indeling van het Handboek Bodem en Bemesting. Gewassen van gewasgroep 0 met de hoogste fosfaatbehoefte werden in de periode 2000-2016 niet geteeld. De behandeling zonder fosfaatbemesting op zandgrond heeft een zeer lage fosfaattoestand. Onder deze conditie worden opbrengstdervingen gevonden bij gewassen van de gewasgroepen $1 \mathrm{t} / \mathrm{m} 4$ die een vergelijkbare orde van grootte hebben (17-26\%).

Evenwichtsbemesting op zavel kan bij gewasgroep 1 leiden tot een opbrengstderving tot 4\%, bij overige gewasgroepen is dit minder dan $1 \%$. Op de zandgrond zijn de dervingen groter, tot $18 \%$.

De veldproeven in Lelystad, Wijster en Marknesse wijzen uit dat het fosforgehalte in het geoogste gewas toeneemt met een toenemende fosfaattoestand en/of fosfaatgift. De toename in het fosforgehalte wordt gevonden bij een breed bereik van fosfaatgiften (tot $240 \mathrm{~kg} \mathrm{P}_{2} \mathrm{O}_{5} / \mathrm{ha}$ ) en hierbij is bij hoge bemestingen en hoge fosfaattoestanden vaak sprake van luxe-consumptie; i.e. het fosforgehalte neemt toe terwijl de opbrengst niet verder toeneemt.

Op de zavelgrond van Lelystad voeren suikerbiet, peen en wintertarwe bij een fosfaatgift van $70 \mathrm{~kg}$ $\mathrm{P}_{2} \mathrm{O}_{5} /$ ha meer fosfaat af dan de fosfaat-aanvoernorm in de mestwetgeving bij toestand neutraal van $60 \mathrm{~kg} \mathrm{P}_{2} \mathrm{O}_{5} / \mathrm{ha}$. Gemiddeld over alle teelten in deze proef ligt de fosfaatafvoer iets boven de $60 \mathrm{~kg}$ $\mathrm{P}_{2} \mathrm{O}_{5} /$ ha. Op de zavelgrond van Marknesse is de afvoer lager dan $60 \mathrm{~kg} \mathrm{P}_{2} \mathrm{O}_{5} /$ ha bij giften lager dan $90 \mathrm{~kg} \mathrm{P}_{2} \mathrm{O}_{5} / \mathrm{ha}$. Dit wordt ook bij het dekzand van Wijster gevonden; bij snijmaïs is de afvoer dan gemiddeld $62 \mathrm{~kg} \mathrm{P}_{2} \mathrm{O}_{5} / \mathrm{ha}$. Variatie in de fosfaatafvoer wordt vooral ingebracht door verschillen in opbrengst tussen proefjaren.

De veldproeven tonen alle aan dat bij veeljarige voortzetting van een fosfaatbehandeling de fosfaattoestand (Pw-getal) na circa 10 jaar stabiliseert. De fosfaattoestand vertoont daarna weliswaar een grote variatie tussen jaren, maar van een feitelijke toename is geen sprake. De hoeveelheid fosfaat die dan nodig is om die min of meer stabiele fosfaattoestand te handhaven boven de gewasafvoer is afhankelijk van de fosfaattoestand. Bij de toestand neutraal te Lelystad is $11 \mathrm{~kg}$ $\mathrm{P}_{2} \mathrm{O}_{5} /$ ha extra nodig boven de onttrekking om die toestand te handhaven. Bij Marknesse stelt de fosfaattoestand (Pw-getal) zich bij strikte evenwichtsbemesting in op een voldoende fosfaattoestand (22 $\mathrm{mg} \mathrm{P}_{2} \mathrm{O}_{5} / \mathrm{L}$ ). Bij de veldproef te Marknesse blijft de fosfaattoestand laag bij strikte 
evenwichtsbemesting ( $\mathrm{Pw}$-getal $10 \mathrm{mg} \mathrm{P}_{2} \mathrm{O}_{5} / \mathrm{L}$ ). Het verhogen van de fosfaattoestand naar een toestand voldoende vraagt hier om een reparatiebemesting.

De profielbemonsteringen leren dat een overschot aan fosfaat niet uitsluitend accumuleert in de bouwvoor, maar ook in bodemlagen onder de bouwvoor. De bodemlagen onder de bouwvoor op de zavelgronden zijn aanzienlijk rijker aan fosfaat dan die op dekzand. Dit wordt als een van de oorzaken gezien waarom dekzand een scherpere gewasreactie toont op fosfaatbemesting en fosfaattoestanden dan de zavelgronden. De zavelgrond van Marknesse is onder de bouwvoor rijker aan fosfaat dan de zavel van Lelystad. De rijkdom onder de bouwvoor wordt opgevat als een oorzaak waarom een gewasreactie op fosfaatbemesting bij Marknesse geringer is dan die te Lelystad. Hierin wordt een aanwijzing gevonden dat bodemlagen onder de bouwvoor bijdragen aan de gewasreactie en ook kunnen naleveren aan de bouwvoor.

Profielbemonsteringen te Marknesse en Wijster zijn momentopnames voor 2002. Voor deze locaties geeft de profielbemonstering geen uitsluitsel of residueel fosfaat van meststof wordt omgezet in fosfaatbodemfracties die niet tot uitdrukking komen in de standaardbodemtesten als P-CaCl, $\mathrm{Pw}-\mathrm{getal}$ en P-Al-getal. Voor de locatie Lelystad wordt wel een aanwijzing gevonden: een deel van het fosfaatoverschot wordt teruggevonden in P-oxalaat, dit is een maat voor de hoeveelheid fosfaat gebonden aan minerale bodemdeeltjes. Residuair meststof wordt omgezet tot bodemfosfaat dat niet meer direct beschikbaar is voor het gewas.

Bemonsteringen van bodemvocht op $35 \mathrm{~cm}$ te Lelystad tonen een forse toename van opgelost mineraal fosfaat (ortho-P) bij toename van de fosfaattoestand (Pw-getal). Op $75 \mathrm{~cm}$ wordt geen effect van opgelegde behandeling op de ortho-P-concentratie vastgesteld. Uitmijnen van fosfaat leidt tot een daling van het gehalte aan ortho-P in de bouwvoor. Op de locaties Marknesse en Wijster zijn de gehalten aan ortho-P zeer laag op $35 \mathrm{~cm}$ en dieper gelegen bodemlagen $(75 \mathrm{~cm}$ en $150 \mathrm{~cm}$ ). Een effect van de fosfaatgift op het gehalte aan ortho-P werd niet vastgesteld. Hierbij moet worden opgemerkt dat de concentraties veelal zeer laag zijn, bodemvochtmetingen normaliter een sterke variatie tonen door invloed van weersomstandigheden en dat er slechts in vijf seizoenen gemonitord is.

De veldproeven op bouwland te Marknesse en Wijster geven geen indicatie dat veeljarige toepassing van evenwichtsbemesting met minerale fosfaatmeststoffen leidt tot een daling van het gehalte aan organische stof. De veldproef te Lelystad kan hierover geen uitsluitsel geven. 


\title{
Beleidssamenvatting
}

\author{
Inleiding \\ In het kader van verplichtingen voortkomend uit de Nitraatrichtlijn (1991) heeft Nederland \\ fosfaatgebruiksnormen ingevoerd (2006). Deze fosfaatgebruiksnormen zijn afhankelijk van de \\ fosfaattoestand van de bodem. Met de Europese Commissie is afgesproken dat vanaf 2015 \\ evenwichtsbemesting wordt ingevoerd. De fosfaatgebruiksnorm is dan gelijk aan de afvoer met \\ landbouwproducten verruimd met een overschot van $5 \mathrm{~kg}$ fosfaat per ha ( $5^{\mathrm{e}}$ Actieplan Nitraatrichtlijn). \\ Het is onduidelijk of dit beleid op de lange termijn nadelige effecten heeft voor de gewasopbrengst, \\ gewaskwaliteit of bodemvruchtbaarheid. Evenmin is bekend of een verlaging van het gebruik in \\ meststoffosfaat leidt tot een vermindering van de fosfaatuitspoeling. Om deze kennisleemtes te \\ kunnen vullen, is veeljarig onderzoek nodig waarbij het verloop in gewasopbrengst, \\ bodemvruchtbaarheid en fosfaatuitspoeling wordt gevolgd. Zodoende is in 1996 gestart met \\ veldproeven op grasland en zijn veldproeven op bouwland, reeds gestart in de jaren zeventig, \\ gecontinueerd. Dit rapport geeft een synthese van de resultaten van het veeljarige fosfaatonderzoek \\ op grasland en bouwland in de periode 2000-2016.
}

De stand van zaken van het veeljarige fosfaatonderzoek op grasland en bouwland in de periode 20002016 leidt tot de volgende antwoorden op drie vragen. Deze vragen zijn daarbij aangepast aan de actualiteit van 2017, mede gelet op invulling van het zesde actieprogramma nitraatrichtlijn.

\section{Leidt toepassing van een gebruiksnorm voor fosfaat, afgestemd op evenwichtsbemes- ting, tot een afname van de gewasopbrengst en kwaliteit en is er een moment waarop deze afname stabiliseert?}

\section{Grasland}

Er wordt vastgesteld dat de opbrengst bij evenwichtsbemesting bij initiële toestand neutraal vanaf het begin lager is dan die bij een overschotbemesting. Het vergde circa 8 jaar voor dit verschil significant werd. De gewasopbrengsten vertonen namelijk een grote jaarlijkse (temporele) variatie waardoor niet beoordeeld kan worden of evenwichtsbemesting in de loop der tijd leidt tot een afname in de gewasopbrengst en -kwaliteit. Wel kan, vanwege de geconstateerde daling in de bodemvruchtbaarheid (P-Al-getal, $\mathrm{P}-\mathrm{CaCl}_{2}$ ) op zandgrond, verwacht worden dat de gewasopbrengst op zandgronden bij evenwichtsbemesting op enig moment gaat dalen. Een overschot van $40 \mathrm{~kg} \mathrm{P}_{2} \mathrm{O}_{5}$ handhaaft de opbrengst op het oorspronkelijk niveau.

Evenwichtsbemesting leidt op zand- en veengrond met een neutrale fosfaattoestand tot $6 \%$ opbrengstderving (700 kg drogestof/ha) ten opzichte van overschotbemesting. Op kleigrond met een neutrale fosfaattoestand wordt geen opbrengstderving geconstateerd. Daarnaast leidt evenwichtsbemesting op alle grondsoorten tot een lagere gewaskwaliteit (lager P-gehalte) in vergelijking met overschotbemesting. Deze verschillen zijn vastgesteld op basis van gemiddelde gewasopbrengsten van langjarige veldproeven (16-19 jaar) op zandgrond (Heino, Soerendonk), kleigrond (Lelystad) en veengrond (Zegveld) waarbij is bemest met runderdrijfmest. De totale fosfaataanvoer bedraagt 77 tot $93 \mathrm{~kg} \mathrm{P}_{2} \mathrm{O}_{5} /$ ha (vanuit bemesting en beweiding) en is in overeenstemming met de huidige gebruiksnorm bij fosfaattoestand neutraal ( $90 \mathrm{~kg} \mathrm{P}_{2} \mathrm{O}_{5} / \mathrm{ha}$ ).

\section{Bouwland}

Vanwege jaarlijks wisselende gewassen (en rassen) op de proefpercelen (door gewasrotatie) en jaarlijkse variatie in opbrengst door weerseffecten, kan niet worden afgeleid of sprake is van een dalende gewasopbrengst of -kwaliteit bij evenwichtsbemesting. Wel kunnen de opbrengsten bij evenwichtsbemesting vergeleken worden met opbrengsten behaald bij overschotbemesting.

Een fosfaatgebruiksnorm afgestemd op strikte evenwichtsbemesting (in dit onderzoek 52-70 kg $\mathrm{P}_{2} \mathrm{O}_{5} /$ ha) geeft een risico op opbrengstderving bij de teelt van fosfaatbehoeftige gewassen 
(gewasgroep 1) op gronden met een lage fosfaattoestand. Op deze gronden zijn de gemiddelde gewasopbrengsten 5-6\% lager dan die behaald worden bij een hogere fosfaatbemesting en/of hogere fosfaattoestand. Op percelen met een neutrale of hoge fosfaattoestand zijn er geen aanwijzingen voor opbrengstderving bij evenwichtsbemesting ( $70 \mathrm{~kg} \mathrm{P}_{2} \mathrm{O}_{5} / \mathrm{ha}$ ) ten opzichte van behandelingen met een hogere fosfaatbemesting. Deze conclusies zijn gebaseerd op resultaten van drie veldproeven gelegen op kalkrijke zavelgrond (Lelystad, Marknesse) en zandgrond (Wijster). De percelen zijn bemest met minerale fosfaatmeststof en de looptijden van de behandelingen variëren van 10 tot 44 jaar.

\section{Leidt een veeljarige toepassing van een gebruiksnorm voor fosfaat afgestemd op evenwichtsbemesting tot een vermindering van de fosfaatbeschikbaarheid of het organische-stofgehalte?}

\section{a. Daalt de voor het gewas beschikbare bodemvoorraad fosfaat?}

\section{Grasland}

Evenwichtsbemesting leidt op zandgronden tot een significante daling van de fosfaattoestand (P-Algetal). Op klei- en veengrond zijn geen aanwijzingen voor een daling in de fosfaattoestand.

Op zandgronden met een - conform indeling uit de Meststoffenwet - neutrale fosfaattoestand, daalt het P-Al-getal bij evenwichtsbemesting in vijftien jaar met 5-15 eenheden waardoor de fosfaattoestand kan veranderen van neutraal naar laag. De gemiddelde fosfaataanvoer bij evenwichtsbemesting bedroeg $81-88 \mathrm{~kg} \mathrm{P}_{2} \mathrm{O}_{5} / \mathrm{ha}$. Om het P-Al-getal op zandgronden te handhaven, is een overschot van circa 20-40 kg $\mathrm{P}_{2} \mathrm{O}_{5}$ /ha nodig. Op zeekleigrond (Lelystad) blijft het P-Al-getal bij evenwichtsbemesting gehandhaafd. Dit is deels te verklaren door het optreden van bodemvormende processen welke specifiek zijn voor jonge kleigronden (o.a. opname van fosfaat uit diepere lagen en opbouw van organische stof). Deze resultaten kunnen zodoende niet vertaald worden naar de veel oudere rivier- en zeekleigronden. Op veengrond (Zegveld) vertoont het P-Al-getal een zeer sterke temporele variatie waardoor het niet mogelijk is om een verloop in de tijd vast te stellen.

Verder onderzoek wijst uit dat ook andere indicatoren voor de fosfaatbeschikbaarheid (Pw-getal, $\mathrm{P}-\mathrm{CaCl}_{2}$ ) op zandgronden een afnemende trend vertonen bij evenwichtsbemesting. Ook het oxalaatextraheerbare fosfaat toont een afname terwijl P-totaal gehandhaafd blijft. Dit duidt op vastlegging van fosfaat in fosfaatvormen welke niet beschikbaar zijn voor plantopname (organisch fosfaat, zeer stabiele mineralen). Naar verwachting zal de afname in fosfaatbeschikbaarheid zich op de langere termijn vertalen in afnemende gewasopbrengsten op grasland. Dit vraagt om continuering van de proef.

\section{Bouwland}

Conform de huidige fosfaatgebruiksnormen wordt de fosfaatstatus op bouwland beoordeeld aan de hand van het Pw-getal. Het Pw-getal toont een zeer grote temporele variatie en kan binnen enkele jaren 15 tot 30 eenheden variëren. De fosfaattoestand van een perceel kan hierdoor van jaar tot jaar één klasse verschillen.

Op zavel- en zandgrond met een initieel laag $\mathrm{Pw}$-getal is bemesting met $70-90 \mathrm{~kg} \mathrm{P}_{2} \mathrm{O}_{5}$ onvoldoende om de fosfaattoestand te verhogen naar neutraal (Marknesse, Wijster). Bij deze mate van fosfaatbemesting stabiliseert het Pw-getal zich na circa 40 jaar rond een waarde van 20-25 mg $\mathrm{P}_{2} \mathrm{O}_{5} / \mathrm{L}$. Om een toestand neutraal te bereiken en te handhaven is meer fosfaat nodig. Het benodigde overschot varieert per locatie. Op Marknesse en Wijster wordt een neutrale fosfaattoestand gehandhaafd door een extra bemesting met 160-180 kg $\mathrm{P}_{2} \mathrm{O}_{5}$. Deze bodems bufferen fosfaat sterk. Op zavelgrond in Lelystad is bemesting met $70 \mathrm{~kg} \mathrm{P}_{2} \mathrm{O}_{5}$ al voldoende om het Pw-getal gedurende 15 jaar te handhaven op een niveau van rond de $42 \mathrm{mg} \mathrm{P}_{2} \mathrm{O}_{5} / \mathrm{L}$. Deze bemesting komt overeen met een gemiddeld fosfaatoverschot van $11 \mathrm{~kg} \mathrm{P}_{2} \mathrm{O}_{5} /$ ha. Continuering van de proef is nodig om te beoordelen of het Pw-getal ook op langere termijn gehandhaafd blijft. 


\section{b. Daalt door toepassing van fosfaatgebruiksnorm het organische-stofgehalte van de bodem?}

\section{Grasland}

De opzet van de proeven kent de aanvoer van organische stof niet als behandeling, maar het organische-stofgehalte wordt wel gemonitord. Evenwichtsbemesting van grasland met rundermest leidt gedurende de looptijd van de veldproeven (16-19 jaar) niet tot afname van het organischestofgehalte van de bodem $(0-30 \mathrm{~cm})$ op zand- en veengrond. Op kleigrond wordt een toename van het organische-stofgehalte vastgesteld.

\section{Bouwland}

Ook de opzet van veldproeven de aanvoer van organische stof niet als behandeling. Incidenteel werd het organische-stofgehalte bepaald. Beschikbare metingen wijzen uit dat het organische-stofgehalte niet daalt bij evenwichtsbemesting met minerale meststoffen.

\section{Leidt een veeljarige toepassing van een gebruiksnorm voor fosfaat, afgestemd op evenwichtsbemesting, tot een vermindering van de fosfaatuitspoeling?}

Tot 2011 werden op de grasproefvelden jaarlijks bodemvochtmonsters genomen om deze vraag te beantwoorden. Deze analyses werden nadien gestaakt door krimp van budget leidend tot aanpassing van de beleidsvragen in het programma van eisen. Bij de veldproeven op bouwland werd gedurende zes seizoenen bodemvocht bemonsterd.

\section{Grasland}

Fosfaatconcentraties in het bodemvocht (centrifuge methode) worden beïnvloed door weersomstandigheden en vertonen zodoende een zeer sterke temporele variatie. Hierdoor kunnen geen trends in de tijd worden afgeleid. Wel kunnen de gemiddelde fosfaatconcentraties bij evenwichtsbemesting vergeleken worden met die bij overschotbemesting.

De effecten van evenwichtsbemesting op fosfaatconcentraties in het bodemvocht beperken zich tot de bovenste $5 \mathrm{~cm}$ van de bodem. In deze laag worden op veen- en kleigrond gemiddeld lagere fosfaatconcentraties gemeten bij evenwichtsbemesting dan bij overschotbemesting. Op zandgrond werd geen verschil gevonden. Onder graszode (20-30 cm diepte) zijn fosfaatconcentraties in het bodemvocht bij evenwichtsbemesting gelijk aan die bij overschotbemesting. Dit betekent dat het risico op uitspoeling van fosfaat vanuit de graszode bij evenwichtsbemesting gelijk blijft aan die bij overschotbemesting. Uitsluitend op veengrond waar sprake is van een overwegend laterale uitspoeling uit de bovenste $10 \mathrm{~cm}$ van de bodem is de fosfaatuitspoeling bij evenwichtsbemesting lager dan bij overschotbemesting. Op alle grondsoorten spoelt fosfaat hoofdzakelijk uit in de vorm van organisch en/of colloïdaal fosfaat.

Ook bij een extreme vorm van uitmijnen (geen fosfaatbemesting) in de periode 2004-2011 beperken de effecten zich tot een daling in fosfaatconcentraties in de bovenste $10 \mathrm{~cm}$ van de bodem, terwijl fosfaatconcentraties aan de onderzijde van wortelzone (20-30) niet veranderen.

\section{Bouwland}

Fosfaatconcentraties in het bodemvocht, bepaald met kunstwortels, zijn slechts in vijf seizoenen gemonitord waardoor geen trend in de tijd kan worden afgeleid. Het is wel mogelijk om de gemiddelde fosfaatconcentraties in het bodemvocht bij evenwichtsbemesting te vergelijken met die bij overschotbemesting.

Fosfaatconcentraties in het bodemvocht onder de bouwvoor (35 cm diepte) zijn veelal zeer laag (0,01-0,1 mg P/l). Op zandgrond (Wijster, Marknesse) zijn de fosfaatconcentraties bij evenwichtsbemesting gelijk aan die bij bemesting met 160 tot $240 \mathrm{~kg} \mathrm{P}_{2} \mathrm{O}_{5} / \mathrm{ha}$. Op zavelgrond (Lelystad) zijn de fosfaatconcentraties in het bodemvocht bij evenwichtsbemesting lager dan bij een bemesting met 140 of $280 \mathrm{~kg} \mathrm{P} \mathrm{O}_{5} / \mathrm{ha}$. Op deze locatie is het risico op uitspoeling van fosfaat bij een (hoog) fosfaatoverschot groter dan op de locaties Marknesse en Wijster. Op grotere diepte (75-155 cm) zijn op zowel zandgrond als kleigrond de fosfaatconcentraties zeer laag $(<0,01 \mathrm{mg} P / \mathrm{l})$ 
en onafhankelijk van bemestingsniveau. Op basis van deze (beperkte) veldgegevens zijn de fosfaatconcentraties in de ondergrond onder bouwland onafhankelijk van de mate van fosfaatbemesting en de fosfaattoestand van de bodem.

\section{Discussie en conclusies}

Vastgesteld wordt dat effecten van verandering van overschotbemesting naar evenwichtsbemesting eerder tot uitdrukking komen in de bodem dan in de gewasreactie op fosfaatbemesting en fosfaattoestand. Vastgesteld wordt dat deze veranderingen in de bodem traag verlopen, maar wel leiden tot een steeds voortschrijdende vermindering van die fosfaatbodemfracties die direct beschikbaar zijn voor het gewas. Wanneer deze afname zich daadwerkelijk zal manifesteren in een afname van opbrengst of kwaliteit is niet bekend. De afname van deze voor het gewas belangrijke fosfaatbodemfracties zal naar verwachting gaan bepalen wat het effect is van fosfaatevenwichtsbemesting. Belangrijk wordt hoe deze direct gewas-beschikbare fosfaatbodemfracties (bv. P-CaCl 2 en Pw-getal) gebufferd worden door nalevering van fosfaat uit niet direct gewas-beschikbare fosfaatbodemfracties (bv. P-Al-getal en P-ox). Welke variatie daarbij gaat optreden in $\mathrm{P}-\mathrm{CaCl}_{2}$ en in $\mathrm{P}$-Al-getal is nog niet goed in beeld.

De veldproeven geven een indicatie van de grootte voor de hoeveelheid fosfaat die nodig is om boven de afvoer te worden gegeven om een bepaalde fosfaattoestand te handhaven (landbouwkundig onvermijdbaar fosfaatverlies). Het benodigde fosfaatoverschot wordt voortdurend verdeeld over direct gewas-beschikbare tot niet voor het gewas beschikbare bodemfracties. Bij strikte

evenwichtsbemesting leidt dit tot achteruitgang van direct gewas-beschikbare bodemfracties zoals die met $\mathrm{P}-\mathrm{CaCl}_{2}$ en $\mathrm{Pw}$-getal wordt bepaald. Hoe het landbouwkundig fosfaatoverschot afhangt van $\mathrm{P}-\mathrm{CaCl}_{2}$ en $\mathrm{P}$-Al-getal is nog niet bekend. Daarvoor zijn aanvullende analyses aan gearchiveerde grondmonsters, statistische analyse en wetenschappelijke uitwerking nodig. Deze kennisleemte kan met gegevens van veeljarige trends van de veeljarige veldproeven worden ingevuld. Daarbij is ook kennis nodig over veranderingen in fosfaatfracties die niet met standaardbodemtesten worden bepaald. De informatie over deze fosfaatfracties is beperkt aanwezig bij de grasproef (vooral eerste drie en laatste drie jaren) en summier aanwezig bij de veldproeven op bouwland (incidenteel) en vraagt om aanvullend onderzoek.

Fosfaatmanagement op bouwland bepaalt ook de fosfaattoestand en fosfaatbodemfracties in bodemlagen onder de bouwvoor. Bij de drie locaties werd in 2002 een profielbemonstering uitgevoerd, bij de locatie Lelystad werd in 2009 de profielbemonstering herhaald. De keuze voor deze locatie berust op de grotere dynamiek van fosfaat in de bodem t.o.v. van de locaties Marknesse en Wijster. Het verdient aanbeveling om deze profielbemonstering op alle locaties te herhalen, juist om de effecten van het opgelegde fosfaatmanagement op bouwvoor en ondergrond vast te stellen na respectievelijk 9 jaar (Lelystad) of 16 jaar (Marknesse, Wijster). Dan kunnen de momentopnames van 2002 en 2009 een breder perspectief krijgen. Voortzetting van de veldproeven en verdere analyse van de data dragen bij aan het antwoord op de vraag over het effect van evenwichtsbemesting op de verdeling van fosfaat over fosfaatbodemfracties en leiden daardoor tot een gerichter en beter onderbouwd antwoord op deze vraag.

De vragen uit de praktijk over effecten van evenwichtsbemesting blijven komen. Het uitdragen van de resultaten van de veldproeven blijft actueel om bewustzijn in de landbouwpraktijk te creëren en te onderhouden over de effecten van evenwichtsbemesting. Het gaat niet alleen om ontbrekende kennis, maar ook om het continueren van kennisoverdracht. 


\section{$1 \quad$ Inleiding}

\section{$1.1 \quad$ Aanleiding}

De directe aanleiding van het onderzoek waarvan de resultaten in dit syntheserapport worden beschreven, is de zogenoemde NP-deskstudy van 1994 van de projectgroep Verliesnormen (Oenema en Van Dijk, 1994). Deze studie werd uitgevoerd binnen het toen operationele wettelijke kader om het overschot aan dierlijke mest en de daaruit voortkomende belasting van het milieu te reguleren. Dat kader binnen de Meststoffenwet werd toen gevormd door het MINeralen Aangifte Systeem (MINAS).

De projectgroep Verliesnormen heeft in 1994 in de fosfaatdeskstudy onderzocht bij welke fosfaatbemesting de bodemvruchtbaarheid in stand gehouden wordt (Oenema \& van Dijk, 1994). In deze deskstudy werd een grote bandbreedte gevonden. Uit de berekeningen kwam naar voren dat er tussen 25 en $50 \mathrm{~kg} \mathrm{P}_{2} \mathrm{O}_{5} \mathrm{ha}^{-1} \mathrm{jr}^{-1}$ nodig is om de fosfaattoestand op grasland of bouwland op de waardering voldoende te handhaven. De milieukundig toelaatbare verliezen werden afgeleid uit norm voor de kwaliteit voor zoet stagnant oppervlaktewater welke 0,15 mg totaal $\mathrm{P} / \mathrm{I}$ bedraagt. Bij deze $\mathrm{P}$-concentratie in het bodemvocht van treedt ruwweg $1 \mathrm{~kg} \mathrm{P}_{2} \mathrm{O}_{5} / \mathrm{ha} / \mathrm{jaar}$ uitspoeling op vanuit Nederlandse landbouwgronden.

In november 2000 is het rapport "Actualisering stikstof- en fosfaatdeskstudies" (Schröder \& Corré, 2000) verschenen waarin de aanbeveling wordt gedaan om de langetermijneffecten van $\mathrm{P}_{2} \mathrm{O}_{5}$ verliesnormen te onderbouwen. Met behulp van simulatiemodellen heeft Alterra ${ }^{1}$ berekeningen uitgevoerd om de landbouwkundige en milieukundige effecten van de verliesnormen op lange termijn te voorspellen. Uit de P-deskstudy kwam naar voren dat er een grote onzekerheid bestaat over de hoogte van het fosfaatoverschot dat noodzakelijk is om de fosfaattoestand van landbouwgronden op niveau te houden. Daardoor werden nieuwe begrippen geïntroduceerd:

- Onvermijdbaar fosfaatverlies

- Milieu-acceptabel verlies

Van 1998 tot en met 2005 is MINAS van kracht geweest. In dit systeem waren voor akkerbouw (inclusief alle open teelten) en grasland maximale stikstof- en fosfaatoverschotten toegestaan, de zogenaamde verliesnormen. In het najaar van 2003 is MINAS als sturingsinstrument echter afgekeurd door het Europese hof, omdat niet voldaan werd aan de verplichtingen opgelegd door de Europese nitraatrichtlijn. Een nieuw actieprogramma werd noodzakelijk. Dit heeft geleid tot de invoering van het stelsel van gebruiksnormen per 1-1-2006.

Voor fosfaat wordt op termijn gestreefd naar evenwichtsbemesting. Met evenwichtsbemesting wordt bedoeld dat de aanvoer van fosfaat $\left(\mathrm{P}_{2} \mathrm{O}_{5}\right)$ door bemesting gelijk is aan de afvoer met gewassen waarbij een verliesnorm van $5 \mathrm{~kg}$ fosfaat/ha is toegestaan. In 2006 werden fosfaatgebruiksnormen ingevoerd. In 2009 werd een voorziening ingevoerd om op basis van grondonderzoek een hogere fosfaatgebruiksnorm te mogen gebruiken indien aangetoond werd dat de fosfaattoestand van de bodem laag was. In 2010 zijn alle fosfaatgebruiksnormen gedifferentieerd naar de fosfaattoestand van de bodem. Voor grasland is de hoogte van het P-Al-getal bepalend voor de gebruiksnorm, voor bouwland is dat het Pw-getal. Bij de start van het onderzoek werd er nog van uitgegaan dat evenwichtsbemesting in 2030 gerealiseerd diende te zijn. Het toenmalige vierde Nationaal Milieubeleidsplan ${ }^{2}$ ging daarvan uit. Bij afstemming van het $3^{\mathrm{e}}$ actieplan met de Europese Commissie werd dit tijdstip vervroegd en is afgesproken dat vanaf 2015 het gebruik van fosfaat wordt afgestemd op evenwichtsbemesting. Om deze situatie te bereiken, werden de naar fosfaattoestand gedifferentieerde gebruiksnormen voor grasland en bouwland na invoering enkele malen verlaagd (Tabel 1.1).

\footnotetext{
1 Thans Wageningen Environmental Research

2 Kamerstukken II 2001/02, 27801 , nr. 1
} 
Tabel 1.1 Fosfaatgebruiksnormen ( $\mathrm{kg} \mathrm{P}_{2} \mathrm{O}_{5} / \mathrm{ha}$ ) voor grasland en bouwland 2010-2017.

\begin{tabular}{|c|c|c|c|c|c|c|}
\hline Cultuur & Bepaling & Klasse & 2014 & 2015 & 2016 & 2017 \\
\hline \multirow[t]{3}{*}{ Grasland } & \multirow{3}{*}{$\begin{array}{l}\text { P-Al-getal, } \\
\mathrm{mg} \mathrm{P}_{2} \mathrm{O}_{5} / 100 \mathrm{~g}\end{array}$} & Fosfaatarm of fosfaatfixerend $<16$ & 120 & 120 & 120 & 120 \\
\hline & & Laag $<27$ & 100 & 100 & 100 & 100 \\
\hline & & Hoog $>50$ & 85 & 80 & 80 & 80 \\
\hline \multirow[t]{3}{*}{ Bouwland } & \multirow{3}{*}{$\begin{array}{l}\text { Pw-getal, } \\
\mathrm{mg} \mathrm{P}_{2} \mathrm{O}_{5} / \mathrm{L}\end{array}$} & Fosfaatarm of fosfaatfixerend $<25$ & 120 & 120 & 120 & 120 \\
\hline & & Neutraal $36-55$ & 65 & 60 & 60 & 60 \\
\hline & & Hoog $>50$ & 55 & 50 & 50 & 50 \\
\hline
\end{tabular}

\subsection{Kennisbehoefte}

De grote onzekerheden in de landbouwkundige en milieukundige verliesnormen vormen de aanleiding voor additioneel onderzoek om deze waarde met een grotere nauwkeurigheid vast te kunnen stellen. Tevens rezen er vragen over de landbouwkundige en milieukundige gevolgen bij hantering van de verliesnormen. Om goed vast te kunnen stellen welke effecten de verliesnormen hebben op grasproductie, -kwaliteit en bodemvruchtbaarheid, is veldonderzoek onder praktijkomstandigheden noodzakelijk voor een traject van verliesnormen voor $\mathrm{N}$ en $\mathrm{P}_{2} \mathrm{O}_{5}$ op verschillende grondsoorten. Deze kennisvraag is directe aanleiding geweest voor het aanleggen van de grasproef op dekzand, klei en veen en adaptatie van de veeljarige veldproeven op bouwland.

In najaar 1996 is, om de invloed van beweiding en dierlijke mest vast te stellen, door Praktijkonderzoek Rundvee, Schapen en Paarden (nu Wageningen Livestock Research (WLR)), NMI en Alterra (nu Wageningen Environmental Research (WENR)) een onderzoek opgestart naar de effecten van verschillende fosfaatverliesnormen onder beweidingsomstandigheden met toepassing van organische mest. Daarvoor is op vier locaties een veldproef aangelegd met daarin een drietal $\mathrm{P}_{2} \mathrm{O}_{5}$ overschotten en twee $\mathrm{N}$-overschotten. De percelen worden afwisselend gemaaid en beweid en er wordt dunne rundermest toegediend. De gewasopbrengst, gewaskwaliteit en fosfaatgehalten in de bodem worden gemonitord. Eveneens zijn $\mathrm{P}_{2} \mathrm{O}_{5}$-verliezen door uit- en afspoeling gemeten.

Op bouwland waren al vier veeljarige veldproeven aangelegd die geschikt zijn om effecten van verschillende fosfaatverliesnormen op gewasopbrengst en bodemvruchtbaarheid te onderzoeken. Deze proeven zijn gecontinueerd, waarbij de uitvoering en monitoring werden aangepast aan het onderzoek naar verliesnormen.

De veeljarige veldproeven zijn opgezet om de effecten van evenwichtsbemesting op opbrengst en kwaliteit, reductie van de mate van fosfaatuitspoeling en de mate en duur van nalevering van fosfaat uit bodemfracties te kunnen kwantificeren. Deze proeven hebben in de loop der jaren geleid tot publicaties in de vorm van informatiebladen, vakbladartikelen en wetenschappelijke artikelen d.m.v. peerreview (Dekker en Ehlert, 2003, 2005, 2008; Dekker et al., 2009; Ehlert et al., 2003, 2008, 2012, 2015; Middelkoop et al., 2012, 2015; Salm et al., 2012, 2017; Wijk et al., 2013). Deze publicaties vormen de bron voor dit syntheserapport. Met deze resultaten wordt inzichtelijk wat de consequenties zijn van evenwichtsbemesting op de lange termijn en welke ontwikkelingen zich daarbij voordoen. Een langetermijnaanpak is hierbij noodzakelijk omdat deze effecten zich pas na vele jaren geleidelijk gaan manifesteren.

De informatie over effecten van fosfaatgebruik op langere termijn t.a.v. van opbrengst en kwaliteit, verdeling over fosfaatbodemfracties en uit- en afspoeling naar het oppervlaktewater dient ter ondersteuning van de beleidsontwikkeling bij het stelsel van fosfaatgebruiksnormen door het ministerie van Landbouw, Natuur en Voedselveiligheid (LNV) gericht op onderbouwing van de fosfaatgebruiksnormen bij evenwichtsbemesting. Onderdeel van onderzoek - dat in 2012/2013 werd afgesloten - vormde ook het effect van fosfaatgebruik op de mate van fosfaatuitspoeling. 


\subsection{Vraagarticulatie voortkomend uit de kennisbehoefte}

De kennisbehoefte heeft geleid tot de volgende vraagarticulatie die enigszins gewijzigd ${ }^{3}$ is na overleg met het ministerie van Economische Zaken (thans ${ }^{4}$ LNV) in het voorjaar van 2017.

1. Leidt toepassing van een gebruiksnorm voor fosfaat, afgestemd op evenwichtsbemesting, tot een afname van de gewasopbrengst en kwaliteit en is er een moment waarop deze afname stabiliseert?

2. Leidt een veeljarige toepassing van een gebruiksnorm voor fosfaat, afgestemd op evenwichtsbemesting, tot een vermindering van de fosfaatbeschikbaarheid of het organischestofgehalte?

3. Leidt een veeljarige toepassing van een gebruiksnorm voor fosfaat, afgestemd op evenwichtsbemesting, tot een vermindering van de fosfaatuitspoeling?

\section{$1.4 \quad$ Doel van het syntheserapport}

Op verzoek van het ministerie is een syntheserapport geschreven dat onderzoeksresultaten bijeenbrengt uit de periode 2000-2016. Dit syntheserapport put daarbij uit publicaties die in informatiebladen, vakbladen en wetenschappelijke tijdschriften in deze periode zijn verschenen. Aan de hand van deze verzamelde informatie worden de vragen van paragraaf 1.3 beantwoord. De vraagarticulatie is in de periode van uitvoering aangepast door beperkingen van het onderzoeksbudget. Monitoring van fosfaatuitspoeling wordt sinds het seizoen 2012/2013 niet meer uitgevoerd.

De doelen van dit syntheserapport zijn:

1. Beantwoording van de vragen gesteld in paragraaf 1.3 op basis van de huidige stand van zaken van uitvoering van de veeljarige veldproeven.

2. Een doorkijk geven van de betekenis van de resultaten van onderzoek voor (toekomstige) fosfaatgebruiksnormen, fosfaatevenwichtsbemesting en waterkwaliteit.

Het syntheserapport brengt onderzoeksresultaten bijeen. Veelvuldig zal het rapport teruggrijpen op achtergronden, data en conclusies die in andere - openbare - publicaties beschreven zijn. Voor achtergronden wordt verwezen naar die publicaties.

Het rapport is als volgt opgebouwd: hoofdstuk 2 geeft generieke informatie over opzet en uitvoering van het onderzoek. In hoofdstuk 3 worden de resultaten van de grasproef besproken. Hoofdstuk 4 geeft de resultaten van de veldproeven op bouwland. In hoofdstuk 5 ten slotte wordt een evaluatie van de beschikbare resultaten uitgevoerd en wordt ingegaan op de implicaties ervan voor huidig mestbeleid.

3 De oorspronkelijke vraagarticulatie was:

1. Welk risico levert een veeljarig toegepaste generieke gebruiksnorm voor fosfaat afgestemd op (strikte) evenwichtsbemesting op opbrengst en kwaliteit van landbouwgewassen?

2. Vermindert een gebruiksnorm afgestemd op (strikte) evenwichtsbemesting op korte en lange termijn het risico op fosfaatuitspoeling?

3. In welke mate zijn deze risico's van een gebruiksnorm voor fosfaat afgestemd op (strikte) evenwichtsbemesting afhankelijk van de bemestingshistorie en de verdeling van de fosfaatfracties in de bodem en welke betekenis heeft deze verdeling voor effecten op de lange termijn?

4 April 2018 


\section{$2 \quad$ Opzet en uitvoering}

\section{$2.1 \quad$ Veldproeven op grasland}

\subsubsection{Opzet}

\section{Bemesting met fosfaat- en stikstofoverschotten}

In 1997 is door Wageningen UR een veldproef op grasland aangelegd om onder praktijkomstandigheden te onderzoeken hoe grasland zich op lange termijn bij verschillende fosfaaten stikstofoverschotten gedraagt. Ten opzichte van klassieke bemestingsproeven waren er vier bijzonderheden in deze proef:

1. er is organische mest toegediend;

2. in de proef is geweid met runderen;

3. de behandelingen zijn gebaseerd op oplopende fosfaat- en stikstofoverschotten in plaats van oplopende bemestingstrappen;

4. een volledig onbemeste behandeling is niet aanwezig.

De proef is aangelegd op drie verschillende grondsoorten op vier locaties: dekzand (Heino, OV, en Soerendonk, NB), jonge zeeklei (Lelystad, FL) en veen (Zegveld, UT). Bij aanvang van de proef was de fosfaattoestand van deze percelen ruim voldoende volgens het toen geldende bemestingsadvies, alle percelen vielen in de huidige klasse 'neutraal', zoals die in het gebruiksnormenstelsel voor 2017 wordt gehanteerd. Op elke locatie zijn drie verschillende fosfaatbemestingsniveaus aangelegd: alle zes plots kregen fosfaatevenwichtsbemesting met rundveedrijfmest, op twee plots is met tripelsuperfosfaat jaarlijks een fosfaat $\left(\mathrm{P}_{2} \mathrm{O}_{5}\right)$ overschot van $20 \mathrm{~kg}$ per ha aangelegd en op twee plots een overschot van $40 \mathrm{~kg}$ per ha. De drie fosfaatniveaus zijn aangelegd bij twee stikstofoverschotten: op drie plots werd gestreefd naar een jaarlijks overschot van $180 \mathrm{~kg} \mathrm{~N} / \mathrm{ha}$ en op de overige drie plots $300 \mathrm{~kg} \mathrm{~N} / \mathrm{ha}$. De plots kregen naast stikstof $(\mathrm{N})$ uit rundveedrijfmest ook N met kunstmest. Op iedere locatie zijn er dus drie fosfaatbehandelingen (0, 20 en $40 \mathrm{~kg} \mathrm{P}_{2} \mathrm{O}_{5} /$ ha overschot) gecombineerd met twee stikstofbehandelingen (180 en $300 \mathrm{~kg} \mathrm{~N} /$ ha overschot), resulterend in zes behandelingen per locatie. De proef is uitgevoerd in enkelvoud. Alle plots zijn in elk groeiseizoen twee keer gemaaid en vier keer beweid met pinken of droge koeien.

Op de locatie Heino is het proefveldmanagement sinds 2002 omgeschakeld naar een biologisch management. Sindsdien is de bemesting van de fosfaatoverschotten uitgevoerd met zacht natuurfosfaat (Gafsafosfaat, toegepast in biologische landbouw, 1-2\% wateroplosbaar fosfaat, 30-40\% oplosbaar in citroenzuur) en is de N-bemesting uitsluitend uitgevoerd met dierlijke mest. Er werden twee N-niveaus gecreëerd door de plots met oorspronkelijk 300N overschot door te zaaien met witte klaver.

In 2012 is de proef op locatie Heino (zand) door bezuinigingen afgesloten. In 2013 is de proef op locatie Soerendonk (zand) afgesloten door bouwplannen van de gemeente. Op locatie Zegveld en Lelystad wordt de proef nog altijd gecontinueerd.

Meer details van de proefuitvoering en de statistische analyse staan beschreven in eerdere rapportages en wetenschappelijke publicaties (Van Middelkoop et al., 2004, 2007, 2016; Van der Salm, 2009).

\section{Uitmijnen}

Vanaf 2002 is er op elke locatie één plot toegevoegd aan de proef waar geen fosfaatbemesting plaatsvond. Deze plots lagen aansluitend aan of slechts enkele meters van de bestaande beweide plots. Op deze plots is alleen met $\mathrm{N}$ bemest en gemaaid. In het vervolg van dit rapport wordt dit aangeduid als de uitmijnbehandeling. De toegepaste $\mathrm{N}$-bemesting was gelijk aan die van de $300 \mathrm{~N}-$ 
overschot plots. Op locatie Heino is klaver doorgezaaid. Meer details wordt gegeven door Middelkoop et al., 2007).

\subsubsection{Monitoring gewas, bodem en bodemvocht}

\section{Gewas}

Zowel van de maaisneden als de weidesneden is de opbrengst en samenstelling van het gras bepaald door enkele stroken gras uit te maaien en te wegen. In de weidesneden bleef het gras liggen voor opname door het vee. De daadwerkelijke opname en uitscheiding van de dieren is niet bepaald, omdat dit een interne kringloop is op de plots. De grootte van deze stroom kan wel worden geschat door een aanname van een waarde voor het beweidingsrendement (het deel van het staande gewas dat opgenomen wordt door de dieren, circa 80\%). Van ieder grasmonster is de samenstelling (droge stof, P-gehalte, ruwe celstof, ruw eiwit, overige nutriënten) bepaald. Tot en met 2007 is tevens de verteringscoëfficiënt bepaald om de voederwaarde (VEM, DVE en OEB) te berekenen. De analyses zijn uitgevoerd door ALNN te Ferwert. De meetgegevens zijn statistisch geanalyseerd. Een beschrijving van die toegepaste REML-analyse is beschreven in een wetenschappelijke publicatie (Van Middelkoop et al., 2016).

\section{Bodem en bodemvocht}

De proefvelden zijn jaarlijks bemonsterd in november/december. In de periode 2004-2007 is daarnaast een bemonstering uitgevoerd in het voorjaar. Monsters zijn genomen van de 0-5, 5-10, 10-20 en 20-30 cm bodemlaag. Om tot een homogeen monster te komen, zijn per plot veertig submonsters genomen en samengevoegd tot één monster. Alle analyses zijn uitgevoerd op luchtgedroogde $\left(30^{\circ} \mathrm{C}\right)$ en over 2-mm gezeefde monsters. De bodemmonsters zijn, volgens standaardmethoden, geanalyseerd op $\mathrm{pH}$, organische stof, $\mathrm{P}-\mathrm{CaCl}_{2}, \mathrm{P}-\mathrm{Al}$-getal, $\mathrm{Pw}$-getal, $\mathrm{P}$-oxalaat en P-totaal.

Het organische-stofgehalte (SOM) is bepaald op basis van de bepaling van het gloeiverlies. De $\mathrm{P}-\mathrm{CaCl}_{2}$ is gemeten na extractie van grond met een $0.01 \mathrm{M} \mathrm{CaCl}_{2}$ oplossing $(1: 10 \mathrm{w} / \mathrm{v})$ gevolgd door analyse van het filtraat op ortho-P (Molybdate Reactive $P$, colorimetrische bepaling met behulp van segmented flow analysis (SFA)). Het P-Al-getal is bepaald na extractie met $0.1 \mathrm{M}$ ammonium lactaat plus $0.4 \mathrm{M}$ azijnzuur, gevolgd door analyse van de ortho-P concentratie in het extract. Het Pw-getal is bepaald na extractie met water bij een grond-vloeistof verhouding van 1:60 (v/v). P-oxalaat is bepaald na extractie van grond met ammonium oxalaat. Het extract is geanalyseerd op totaal $P$, ijzer (Fe) en aluminium (AI) met behulp van ICP-AES. Het organisch en anorganisch $P$-gehalte van de grondmonsters is bepaald volgens de P-Kuo-methode.

Bodemvocht is bemonsterd in de periode 1997-2011 in de bodemlagen 0-5, 5-10, 10-20 en 20-30 cm. Omdat fosfaatconcentraties in bodemvocht sterk kunnen variëren tussen seizoenen, zijn over het jaar verdeeld drie metingen uitgevoerd (maart, april/mei en november/december). Om een representatief bodemmonster te verkrijgen, zijn per plot 40 submonsters genomen. Het bodemvocht is door middel van centrifugeren afgescheiden en na filtratie geanalyseerd op totaal-P (ICP-AES) en ortho-P (colorimetrisch).

Analyses van de standaard bodemparameters ( $\mathrm{pH}$, SOM, P-Al-getal, Pw-getal, P-totaal, P-CaCl 2 ) zijn uitgevoerd door Blgg AgroXpertus (huidige Eurofins Agro)in Wageningen. Analyses op het bodemvocht en de research parameters ( $\mathrm{P}$-oxalaat, $\mathrm{P}$-organisch en $\mathrm{P}$-anorganisch) zijn uitgevoerd door het CBLB (chemisch-biologisch laboratorium bodem), onderdeel van Wageningen UR. Een gedetailleerde omschrijving van de gehanteerde analysemethoden is opgenomen in eerdere publicaties (o.a. Middelkoop et al., 2016; Van der Salm et al., 2009, 2017).

Tabel 2.1 geeft een overzicht van de uitgevoerde analyses op de grondmonsters en de periode waarin deze uitgevoerd zijn. Vanwege budgettaire redenen is de monitoring van het bodemvocht in 2011 gestopt. 
Tabel 2.1 Overzicht fosfaat bodemtesten grasproef.

\begin{tabular}{lll} 
P-bodemtest & Omschrijving & Frequentie \\
Bodemvocht & Samenstelling bodemvocht (P-totaal en ortho-P) bepaald & Drie metingen per jaar, tot \\
& na uitslingeren van poriewater uit veldvochtige grond. & 2011 \\
\hline $\mathrm{P}-\mathrm{CaCl}_{2}$ & Direct beschikbaar fosfaat (ortho-P) gemeten in een & 2004-2007: tweemaal per jaar \\
& $0,01 \mathrm{M} \mathrm{CaCl}$ extract, intensiteit. & 2007-2015: jaarlijks \\
\hline Pw-getal & Direct beschikbaar fosfaat (ortho-P), intensiteit & Jaarlijks \\
\hline P-Al-getal & Zwak-gebonden fosfaat (ortho-P), capaciteit & Jaarlijks \\
\hline P-ox & Zwak- en sterk-gebonden fosfaat, gebonden aan Fe- en & Jaarlijks \\
& Al-hydroxiden en kleideeltjes. Hoofdzakelijk ortho-P, deels & \\
\hline P-organisch & organisch-P. & 8 metingen \\
\hline P-totaal & Semi-totale voorraad organisch fosfaat in de bodem & Jaarlijks \\
\hline
\end{tabular}

\subsection{Veldproeven op bouwland}

\subsubsection{Opzet}

Er zijn vier veldproeven gelegen op bouwland welke verschillen in opzet. Alle veldproeven hebben behandelingen die uitsluitsel geven over het effect van evenwichtsbemestingen en alle veldproeven hebben een bereik in fosfaattoestanden van laag tot hoog. Hun ontwerp verschilt onderling en verder onderscheiden veldproeven zich door aanvullende behandelingen. In de huidige opzet kunnen de vier veldproeven op bouwland gekarakteriseerd worden als 1) fosfaattoestanden, 2) fosfaattoestandenhoeveelheden veldproeven en als 3) fosfaathoeveelheden veldproeven. De verschillen tussen deze drie proefopzetten wordt hieronder toegelicht.

Bij een fosfaattoestanden-veldproef is de fosfaattoestand van de bodem een opgelegde behandeling (factor). Een fosfaattoestanden-hoeveelheden veldproef heeft als factor zowel de fosfaattoestand als de fosfaatgift. Dat wil zeggen dat zowel de fosfaattoestand als de fosfaatbemesting opgelegd wordt. Een fosfaathoeveelheden-veldproef (trappenproef) heeft uitsluitend de fosfaatgift als factor. Bij dit laatste type veldproef krijgen de veldjes ieder jaar dezelfde of naar rato dezelfde fosfaatgift. Daardoor zijn permanent onbemeste veldjes aanwezig en veldjes die permanent een (groot) overschot op de fosfaatbalans hebben of een bescheiden tot groot tekort hebben (d.w.z. er wordt meer fosfaat afgevoerd dan met meststof wordt aangevoerd). Door de lange looptijd van de proeven en de zeer grote verschillen in de mate van fosfaatbemesting, is een breed bereik in fosfaattoestanden in de bodem ontstaan, van landbouwkundig laag- tot zeer hooggewaardeerd. Bij de veeljarige uitvoering van de veldproeven werd de proefopzet na ampele afweging gewijzigd door veldjes een andere bemestingsgift te geven, een lagere fosfaatgift of deze geheel te onthouden (uitmijnen).

Er zijn vier veldproeven op bouwland waarvan drie proeven op kalkrijke zavelgrond en één proef op kalkloze dekzandgrond. De volgende aanduidingen worden gebruikt om de vier veldproeven te onderscheiden:

1. Toestanden veldproef P1801 op kalkrijke zavelgrond te Lelystad;

2. Hoeveelheden veldproef IB0013 op kalkrijke zavelgrond te Marknesse;

3. Toestanden-hoeveelheden veldproef IB0016 op kalkrijke zavelgrond te Marknesse;

4. Hoeveelheden veldproef IB1920 op kalkloze dekzand te Wijster. 
Tabel 2.2 Beknopt overzicht proefopzet op de vier bouwlandproeven en monitoringsprogramma van de bodem (details, zie tekst).

\begin{tabular}{|c|c|c|c|}
\hline Locatie & Proefopzet & Omschrijving & Monitoringsprogramma bodem \\
\hline $\begin{array}{l}\text { 1. Lelystad } \\
\text { (P1801) }\end{array}$ & Toestandenproef & $\begin{array}{l}\text { Vier oplopende fosfaatniveaus in de } \\
\text { bodem (fosfaattoestand laag tot hoog) } \\
\text { gecombineerd met vier fosfaatgiften } \\
\left(0,70,140 \text { en } 280 \mathrm{~kg}_{2} \mathrm{O}_{5} / \mathrm{jaar} \text { ). }\right. \\
\text { Bemesting met superfosfaat, uitvoering } \\
\text { in vier herhalingen. }\end{array}$ & $\begin{array}{l}\text { Jaarlijks bemonstering van bodemlagen } \\
0-30 \mathrm{~cm}, 30-60 \mathrm{~cm} \text {. Vanaf } 1990 \text { zijn } \\
\text { Pw-getal, P-Al-getal en P-totaal } \\
\text { gemeten. P-CaCl} 2 \text { vanaf } 2004 .\end{array}$ \\
\hline $\begin{array}{l}\text { 2. Marknesse } \\
\text { (IB0013) }\end{array}$ & Hoeveelhedenproef & $\begin{array}{l}\text { 1. Bemesting (superfosfaat) met } \\
\text { fosfaattrappen van } 0,80,160 \text { en } 250 \mathrm{~kg} \\
\mathrm{P}_{2} \mathrm{O}_{5} / \text { ha sinds } 1971 \text { met vier } \\
\text { herhalingen. Door de grote } \\
\text { bemestingsverschillen is een breed } \\
\text { bereik in fosfaattoestanden ontstaan. } \\
\text { 2. Bemesting (superfosfaat) op basis } \\
\text { van strikte fosfaatevenwichtsbemesting, } \\
\text { tweemaal die hoeveelheid en driemaal } \\
\text { die hoeveelheid. Strikte } \\
\text { evenwichtsbemesting betekent dat de } \\
\text { aanvoer gelijk is aan de afvoer in het } \\
\text { voorgaande jaar. Uitvoering sinds } 1990 \\
\text { bij één fosfaattoestand en met vier } \\
\text { herhalingen. }\end{array}$ & $\begin{array}{l}\text { Jaarlijks bemonstering van bodemlaag } \\
0-25 \mathrm{~cm} \text { op Pw-getal (vanaf 1972). } \\
\text { P-Al-getal vanaf } 2003, \mathrm{P}-\mathrm{CaCl}_{2} \text { vanaf } \\
2008 \text {. }\end{array}$ \\
\hline $\begin{array}{l}\text { 3. Marknesse } \\
\text { (IB0016) }\end{array}$ & Toestandenproef & $\begin{array}{l}\text { Oplopende fosfaattoestanden (zeer laag } \\
\text { tot neutraal) gecombineerd met } \\
\text { bemesting (superfosfaat) met } 0 \\
\text { (uitmijnen) of } 100 \mathrm{~kg} \mathrm{P}_{2} \mathrm{O}_{5} / \mathrm{ha} / \mathrm{jaar} \text {. } \\
\text { Slapende proef (alleen grondonderzoek). }\end{array}$ & $\begin{array}{l}\text { Jaarlijks bemonstering van bodemlaag } \\
0-25 \mathrm{~cm} \text { op Pw-getal (vanaf 1972). } \\
\text { P-Al-getal vanaf } 2003, \mathrm{P}-\mathrm{CaCl}_{2} \text { vanaf } \\
2008 \text {. }\end{array}$ \\
\hline
\end{tabular}

\subsubsection{Fosfaattoestandenproef Lelystad}

Sinds 1990 loopt op een jonge zeekleigrond te Lelystad een langjarige proef waarin het effect wordt onderzocht van fosfaattoestand van de bodem op de gewasopbrengsten en van verschillende fosfaatbemestingsniveaus op de fosfaattoestand van de bodem en het fosfaatoverschot. In de periode 19871990 zijn door verschillende fosfaatgiften met tripelsuperfosfaat vier in niveau oplopende fosfaattoestanden ontstaan: P1, P2, P3 en P4 genoemd. Die toestanden krijgen elk jaar fosfaatgiften van respectievelijk 0, 70, 140 en $280 \mathrm{~kg} \mathrm{P}_{2} \mathrm{O}_{5}$ per ha. De proef is aangelegd in vier herhalingen. De proefopzet is uitgebreid beschreven door Ehlert et al. (2003).

In 2005 zijn de plots gesplitst: op de ene helft van elk plot is de bovengenoemde fosfaatbemesting gecontinueerd, terwijl op de andere helft geen fosfaat meer wordt toegediend ofwel wordt uitgemijnd. Enkel bij P1 (dat al geen fosfaat kreeg) is er sinds 2006 voor gekozen om de ene helft van de plots te blijven uitmijnen en de andere helft jaarlijks $70 \mathrm{~kg} \mathrm{P}_{2} \mathrm{O}_{5}$ per ha te geven.

Op het proefveld wordt een gangbare rotatie van akkerbouwgewassen geteeld. In de rotatie komen gewassen voor uit alle vier de naar fosfaatbehoefte ingedeelde gewasgroepen voor de akkerbouw 
(groepen $1 \mathrm{t} / \mathrm{m}$ 4) die worden onderscheiden in het Handboek Bodem en Bemesting (voorheen de Adviesbasis Bemesting $)^{5}$.

De veldproef te Lelystad heeft vanaf het begin een breed bereik gehad in fosfaattoestanden (Pw-getal, P-Al-getal). Volgens de landbouwkundige beoordeling van de fosfaattoestand (op basis van Pw-getal) varieert deze van laag tot zeer hoog.

\subsubsection{Fosfaathoeveelhedenproef Marknesse}

Op IB0013 Marknesse worden twee type bemestingsproeven uitgevoerd:

1. bemesting met fosfaattrappen van $0,80,160$ en $240 \mathrm{~kg} \mathrm{P}_{2} \mathrm{O}_{5} /$ ha en

2. strikte evenwichtsbemesting.

Door de jaren heen is een bereik van fosfaattoestanden ontstaan. Initieel was de fosfaattoestand laag. In 2016 was het bereik in fosfaattoestanden laag tot neutraal (Pw-getal) of bleef neutraal (P-Al-getal).

Op basis van de historie van de veldproeflocatie wordt de totstandkoming van deze twee proefopzetten verder toegelicht. De veldproef IB0013 is in het najaar van 1971 aangelegd. Het doel daarbij was om de effectiviteit van veeljarige toediening van superfosfaat en Rhenaniafosfaat (een gloeifosfaat ${ }^{6}$ ) bij bemesting op wintervoor te toetsen. De meststofgiften zijn steeds 80, 160 en $240 \mathrm{~kg}$ $\mathrm{P}_{2} \mathrm{O}_{5} /$ ha geweest, gegeven in 4 herhalingen. Daarnaast is een onbemeste behandeling aanwezig met 8 herhalingen. De veldproef omvat daardoor 32 veldjes. In 1973, 1974 en 1975 zijn de fosfaattrappen opgesplitst naar bemestingstijdstippen herfst en winter, waardoor deze behandelingen in tweevoud aanwezig waren. Daardoor werd een nevendoel toegevoegd en wel toetsing van het tijdstip van bemesting op opbrengst en kwaliteit. Na 1975 werd deze doelstelling verlaten en sindsdien is jaarlijks alleen in de winter bemest. Na 1986 zijn de behandelingen met Rhenaniafosfaat op nawerking gelegd, omdat deze meststof uit productie werd genomen. Na vier jaar zonder enige vorm van bemesting zijn de veldjes wederom in gebruik genomen voor een fosfaatproef op basis van evenwichtsbemesting (Ehlert et al., 2000, 2001). De behandelingen met strikte evenwichtsbemesting zijn opgelegd na loting. Vier veldjes ontvangen de hoeveelheid fosfaat die met de oogst van het voorafgaande jaar met het gewas is afgevoerd (M), vier andere ontvangen jaarlijks de dubbele hoeveelheid (2M) en de overige vier veldjes een drievoudige hoeveelheid (3M). Door de loting en door vier voorafgaande jaren zonder enige vorm van fosfaatbemesting startten $M, 2 M$ en $3 M$ alle met gemiddeld eenzelfde fosfaattoestand. De doelstelling van deze wijziging is om na te gaan wat de veeljarige effecten zijn van strikte evenwichtsbemesting op opbrengst en kwaliteit van het gewas en op de omzetting en verplaatsing van fosfaat in bouwvoor en daaronder gelegen bodemlagen. Andere nutriënten worden toegediend conform vigerende bemestingsadviezen. De proef met toediening van superfosfaat is al die tijd ongewijzigd voorgezet waardoor er nu twee verschillende proefopzetten zijn: bemesting met jaarlijks constante fosfaattrappen en strikte evenwichtsbemesting waarbij de fosfaatgift jaarlijks varieert, afhankelijk van de fosfaatafvoer met de voorvrucht. De opzet van de proef berust op een gewarde blokkenproef. Achtergrondinformatie wordt gegeven door Ehlert et al. (2003).

\subsubsection{Fosfaattoestandenproef Marknesse}

De veldproef IB0016 heeft sinds de aanleg in 1972 diverse onderzoeksdoelen gediend (Ehlert et al., 2003) waardoor op de verschillende percelen een groot bereik in fosfaattoestanden is ontstaan. In 1998 werd de proef opgesplitst in blokken met een bereik in fosfaattoestanden (Pw-getal) die niet bemest worden of met 70 (1999-2001) of $100 \mathrm{~kg} \mathrm{P} \mathrm{O}_{5} / \mathrm{ha} / \mathrm{jaar}$ (vanaf 2002) als superfosfaat worden bemest. Sinds 1998 worden opbrengsten niet meer bepaald ('slapende proef'), maar wel de fosfaattoestand. Ook deze fosfaatproef startte met een lage fosfaattoestand. Door verschillend fosfaatmanagement werd een bereik in fosfaattoestanden gecreëerd van laag tot neutraal. Sinds de veldproef sinds 2002 alleen bemeste ( $100 \mathrm{~kg} \mathrm{P} \mathrm{O}_{5} / \mathrm{ha}$ ) behandelingen kent en met fosfaat onbemeste behandelingen, is de fosfaattoestand gedaald tot een bereik zeer laag tot laag (Pw-getal) en laag tot neutraal (P-Al-getal).

\footnotetext{
5 http://www.handboekbodemenbemesting.nl/nl/handboekbodemenbemesting/Handeling/Bemesting/Fosfaat/Gewasgerichtadvies/Gewasgericht-advies-voor-volvelds-fosfaatbemesting-op-basis-van-Pw.htm

6 In 1983 werd de productie van Rhenania fosfaat gestaakt. Herwonnen fosfaten gebaseerd op as van zuiveringsslib heeft de belangstelling voor deze thermische fosfaat hernieuwd.
} 


\subsubsection{Fosfaathoeveelhedenproef Wijster}

De veldproef IB1920 is in 1972 aangelegd. De toen aangelegde behandelingen zijn sedertdien ongewijzigd gebleven, tenzij een bemestingsproduct verviel. Op deze veldproef worden verschillende fosfaatmeststoffen getoetst. De meststoffen zijn superfosfaat, slakkenmeel, Thomaskali (een gekorreld slakkenmeel met $\mathrm{K} 60\left(60 \% \mathrm{~K}_{2} \mathrm{O}\right.$ afkomstig van $\left.\left.\mathrm{KCl}\right)\right)$, Rhenaniafosfaat (gloeifosfaat) en Hyperphoskali (ook wel Hyperfoskali), een zacht natuurfosfaat afkomstig van Gafsa. Deze meststoffen worden onderzocht op hun fosfaatwerking. Al deze meststoffen worden in de herfst gegeven met giften van 90 of $180 \mathrm{~kg} \mathrm{P}_{2} \mathrm{O}_{5} / \mathrm{ha}$. Superfosfaat en Rhenaniafosfaat zijn ook in het voorjaar toegediend met $45,90,180$ of $240 \mathrm{~kg} \mathrm{P}_{2} \mathrm{O}_{5} /$ ha (superfosfaat) of 90 en $180 \mathrm{~kg} \mathrm{P}_{2} \mathrm{O}_{5} /$ ha (Rhenaniafosfaat).

Daarnaast is een onbemeste behandeling aanwezig. Het aantal herhalingen was 3 voor behandelingen met fosfaatbemesting en 6 voor de behandeling zonder fosfaatbemesting. Vanaf 1988 was Rhenaniafosfaat niet meer beschikbaar en de desbetreffende veldjes zijn sindsdien niet meer met fosfaat bemest (nawerking of uitmijnen). Vanaf 2012 zijn behandelingen met slakkenmeel omgezet naar bemesting met superfosfaat ( 60 of $75 \mathrm{~kg} \mathrm{P}_{2} \mathrm{O}_{5} / \mathrm{ha}^{7}$ ). In 2000 is langs het perceel van de veldproef een afvoerkanaal gegraven waardoor één herhaling kwam te vervallen. Sindsdien is het aantal herhalingen 2 bij bemeste objecten en 4 bij het onbemeste object. De behandelingen passen binnen een gewarde blokkenproef.

Deze proef heeft tijdelijk een slapende vorm gekend, d.w.z. geen opbrengstbepalingen gehad in de periode 1998-2006. De bemestingen werden wel uitgevoerd en ook het grondonderzoek maar geen opbrengstbepalingen met daaraan verbonden chemisch gewasonderzoek.

Bij aanleg had de veldproef een fosfaattoestand laag (Pw-getal, P-Al-getal). In 2016 was er een bereik ontstaan van laag naar neutraal (Pw-getal) en van laag naar hoog (P-Al-getal).

\subsubsection{Monitoring gewas, bodem en bodemvocht}

\subsubsection{Gewas}

De veldproeven P1801, IB0013 en IB1920 kennen jaarlijks een bepaling van opbrengst en een chemisch gewasonderzoek op fosfaat waardoor de fosfaatafvoer bekend is. Bij een aantal gewassen worden ook kwaliteitsaspecten (sortering, onderwatergewicht, \%suiker) meegenomen. Het monitoringsprogramma bodem verschilt per veldproef (Tabel 2.2). Proef IB1920 kent een onderbreking van de opbrengstbepaling in de periode 1998-2006, op IB0016 wordt geen opbrengstbepaling uitgevoerd. In deze situaties werd uitsluitend het monitoringsprogramma bodem uitgevoerd.

Bij IB0013 en IB1920 worden de oogstresten afgevoerd.

\subsubsection{Bodem}

Het jaarlijks monitoringsprogramma wordt in Tabel 2.2 gegeven. De methoden van onderzoek zijn beschreven door Ehlert et al. (2003).

\section{Lelystad}

In 2002 en 2009 zijn in aanvulling op dit meetprogramma uitgebreide profielbemonsteringen van de bodemlagen 0-20 cm, 20-30 cm, 30-40 cm, 40-50 cm, 60-80 cm en 80-100 cm uitgevoerd. Dit wordt nader beschreven in paragraaf 4.5 .

\section{Marknesse - IB0013}

In 1991, 1993 en 1996 zijn tevens grondmonsters genomen van de bodemlagen 30-40 cm en 45-65 cm in kader van het West Europees netwerk van IMPHOS (Johnston e.a., 2001). In 2002 werd een profielbemonstering uitgevoerd overeenkomstig die te Lelystad met dezelfde parameters.

\section{Marknesse - IB0016}

In 2012 werd geen grondonderzoek uitgevoerd aan de grondmonsters.

\footnotetext{
7 In dit syntheserapport ontbreekt een bespreking van de resultaten. Deze effecten van deze behandelingen zijn over 4 jaar gemeten en kunnen nog niet geplaatst worden onder de effecten van veeljarige veldproeven.
} 


\section{Wijster - IB 1920}

In 1995 en in 2002 is een profielbemonstering van de bodemlagen 0-20, 20-40, 40-60 en 60-100 cm uitgevoerd. In de grondmonsters zijn Pw-getal, P-Al-getal en P-totaal bepaald (1995), in 2002 dezelfde parameters als bij de veldproef te Lelystad ${ }^{8}$.

\subsubsection{Bodemvocht}

Bodemvochtmetingen zijn uitgevoerd in een aantal geselecteerde behandelingen en gedurende vijf winterseizoenen (2003/2004, 2004/2005, 2006/2007, 2008/2009 en 2009/2010). De bemonsteringen vonden plaats in intervallen van 1-2 maanden om het verloop gedurende de winter in beeld te krijgen. Bodemvocht werd op 35 en $75 \mathrm{~cm}$ diepte (Lelystad, Marknesse) en $35 \mathrm{~cm}$ en $155 \mathrm{~cm}$ (Wijster) opgezogen met behulp van kunstwortels of Rhizon sms (soil moisture samplers). Het bodemvocht werd geanalyseerd op concentraties aan totaal-P en ortho-P (Murphy \& Riley, conform Houba et al., 1997b).

\subsubsection{Chemisch grond- en gewasonderzoek}

\subsubsection{Gewasonderzoek}

Chemisch gewasonderzoek op droge stof en nutriënten volgt methoden beschreven door Temminghoff et al. (2002).

\subsubsection{Grondonderzoek}

In de fosfaattoestandenproef te Lelystad zijn in aanvulling op de jaarlijkse bodemmetingen (Pw-getal, $\mathrm{P}$-Al-getal en vanaf $2004 \mathrm{P}-\mathrm{CaCl}_{2}$ ) in 2002 en in 2009 profielbemonsteringen van de bodemlagen 0-20 cm, 20-30 cm, 30-40 cm, 40-50 cm, 60-80 cm en 80-100 cm uitgevoerd. De grondmonsters werden geanalyseerd aan de hand van:

- $\mathrm{pH}-\mathrm{H}_{2} \mathrm{O}: 1: 5$ (grond/water, V/V) extractie van grond met water (Houba e.a., 1997);

- P-1:2: 1:2 (grond/water, W/V) extractie van grond met water (Sonneveld e.a., 1990);

- Pw-getal: 1:60 (grond/water, V/V) extractie van grond met water (Sissingh, 1971), tevens werd het gewicht van het volume grond $(1,2 \mathrm{ml})$ dat gebruikt werd voor extractie gemeten;

- P-Al-getal: 1:20 (grond/water, W/V) extractie van grond met ammoniumlactaat-azijnzuur met $\mathrm{pH}$ 3,75 (Egnér e.a., 1960);

- P-ox: 1:20 (grond/water, W/V) extractie van grond met ammonium oxalaat-oxaalzuur (Schwertmann, 1964);

- Desorptie-isotherm: cumulatieve Pi-bepaling op basis van 7 tijdstappen. De Pi-bepaling berust op de extractie van $\mathrm{P}$ met een ijzerhydroxide-geïmpregneerd filterpapiertje conform Sissingh (1983). Als achtergrondelektrolyt is $0,005 \mathrm{M} \mathrm{CaCl}_{2}$ gebruikt. Papiertjes werden op zeven tijdstappen vervangen: na 4, 8, 24, 48, 72, 144 en 192 uur;

- Totaal P: destructie met zwavelzuur, salicylzuur, peroxide en seleen volgens Houba e.a. (1997).

\subsubsection{Bewerking}

Alle statistische analyses zijn uitgevoerd met Genstat ${ }^{9}$.

\subsubsection{Lelystad}

Analyses berusten op variantieanalyse (ANOVA) om te toetsen of er een effect is van de P-niveaus, en een tweezijdige t-toets om de LSD-waarden te berekenen (het kleinste betrouwbare verschil) bij een onbetrouwbaarheid van $5 \%$.

Verder is gebruikgemaakt van regressieanalyse om de verandering van de fosfaattoestanden in de tijd te beschrijven (uitgezet tegen de jaren) en als functie van het cumulatieve fosfaatoverschot.

\footnotetext{
8 In dit syntheserapport wordt de periode 2000-2016 behandeld.

9 https://www.vsni.co.uk/software/genstat/
} 


\subsubsection{Marknesse en Wijster}

De analyse van meetgegevens is gebaseerd op variantieanalyse (ANOVA). Toets op paarsgewijze verschillen zijn gebaseerd op de kleinste significante verschillen (LSD). Uitspraken berusten op overschrijdingskans van $95 \%$ ( $a=0,05$, tweezijdig).

Bij de berekening van de cumulatieve fosfaatbalansen zijn ontbrekende waarden geschat uit gemiddelde afvoergegevens van hetzelfde gewas uit voorafgaande jaren. 


\section{Resultaten grasproef}

\subsection{Gewasopbrengst}

De droge stof (ds) opbrengst van het gras was bij evenwichtsbemesting op zand en veen gemiddeld

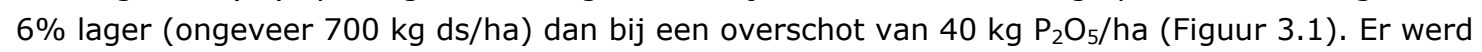
vastgesteld dat de opbrengst bij evenwichtsbemesting van meet af aan lager was dan bij overschotbemesting. Na circa 8 jaar kon aangetoond worden dat dit verschil significant werd. Er kon niet worden aangetoond dat het verschil in opbrengst veranderde gedurende de looptijd van de proef, ondanks de opbouw van de fosfaatvoorraad in de bodem bij bemesting met een fosfaatoverschot. Het verschil in opbrengst kwam in alle sneden naar voren. Bij de verandering van de fosfaatmeststof voor het overschot op locatie Heino in 2002 van het goed oplosbare tripelsuperfosfaat naar het minder oplosbare natuurfosfaat verdween het opbrengstverschil tussen de overschotten. Op de locatie Lelystad waren de drogestofopbrengsten op de drie fosfaatoverschotten niet aantoonbaar verschillend.

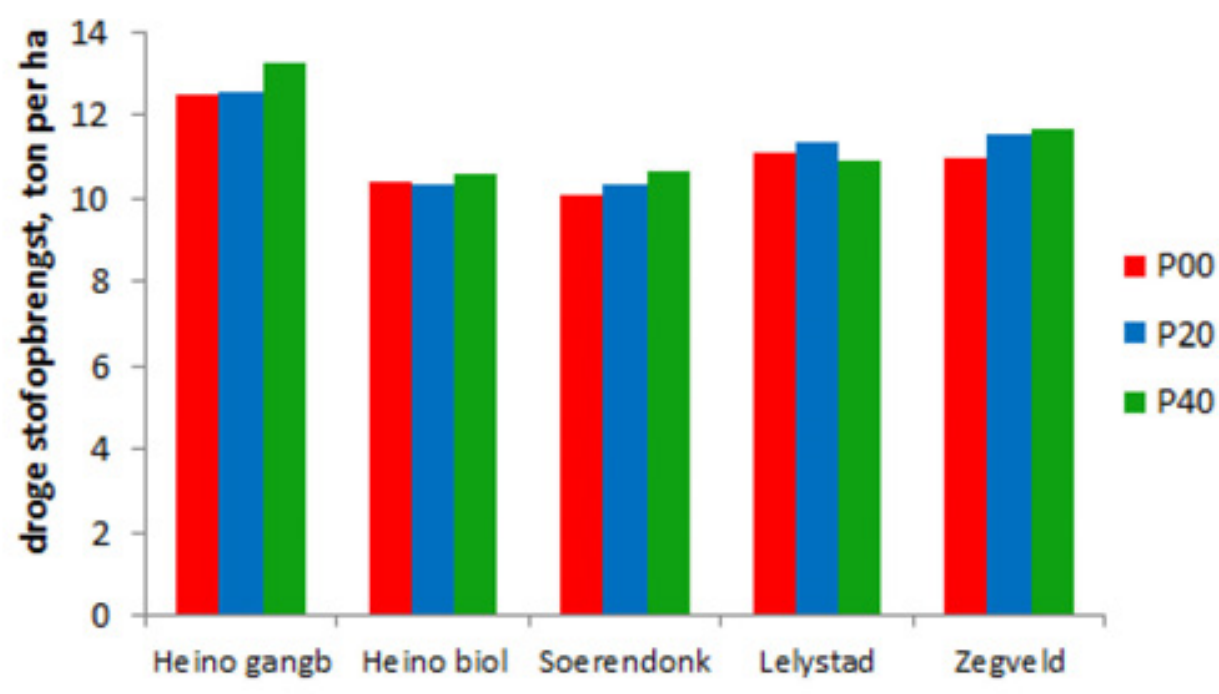

Figuur 3.1 Gemiddelde drogestofopbrengsten van gras bij evenwichtsbemesting (P00), bij een overschotbemesting van $20 \mathrm{~kg}$ fosfaat per ha (P20) of $40 \mathrm{~kg}$ fosfaat per ha (P40), per proeflocatie. Heino gangbaar: 1997-2001; Heino biologisch: 2002-2012, Soerendonk: 1997-2013, Lelystad en Zegveld: 1997-2015.

De verschillen tussen de $\mathrm{N}$-overschotten 180 en $300 \mathrm{~kg} \mathrm{~N} / \mathrm{ha}$ waren op de locaties zoals verwacht mocht worden op basis van graslandonderzoek van de afgelopen jaren op vergelijkbare locaties en met vergelijkbare giften: bij het lagere overschot was de productie ca. 1 ton droge stof op zand en veen en ca. 3 ton droge stof op jonge zeeklei lager (niet weergegeven). 


\section{Uitmijnen}

De drogestofopbrengst bij uitmijnen is weergegeven in Figuur 3.2, samen met de drogestofopbrengst van de behandeling N300-P0 (hoog N-overschot, P-evenwichtsbemesting). Deze plots krijgen, met uitzondering van Heino, een vergelijkbare bemesting met $\mathrm{N}$, alleen het gebruik verschilt (beweiden en maaien vs. alleen maaien). Op locatie Heino is de N300-P00 plot bovendien bemest met $\mathrm{N}$ uit dierlijke mest en de uitmijn-plot niet. De vergelijking is daarom niet helemaal zuiver.

Op de locaties Soerendonk en Lelystad zijn de opbrengsten in de eerste jaren van de beide plots vergelijkbaar. Op de locaties Heino en Zegveld is de opbrengst van de N300-P00 plot steeds hoger dan van de uitmijn-plot. Na ongeveer acht jaar uitmijnen, in 2010, worden de verschillen tussen de beide plots groter. Vooral op de locaties Lelystad en Zegveld blijkt de opbrengst bij uitmijnen sterk te verminderen ten opzichte van evenwichtsbemesting. Op locatie Lelystad is het opbrengstverschil circa 5 ton ds/ha en op locatie Zegveld circa 6 ton ds/ha, ondanks een N-bemesting van circa $400 \mathrm{~kg} \mathrm{~N} / \mathrm{ha}$.
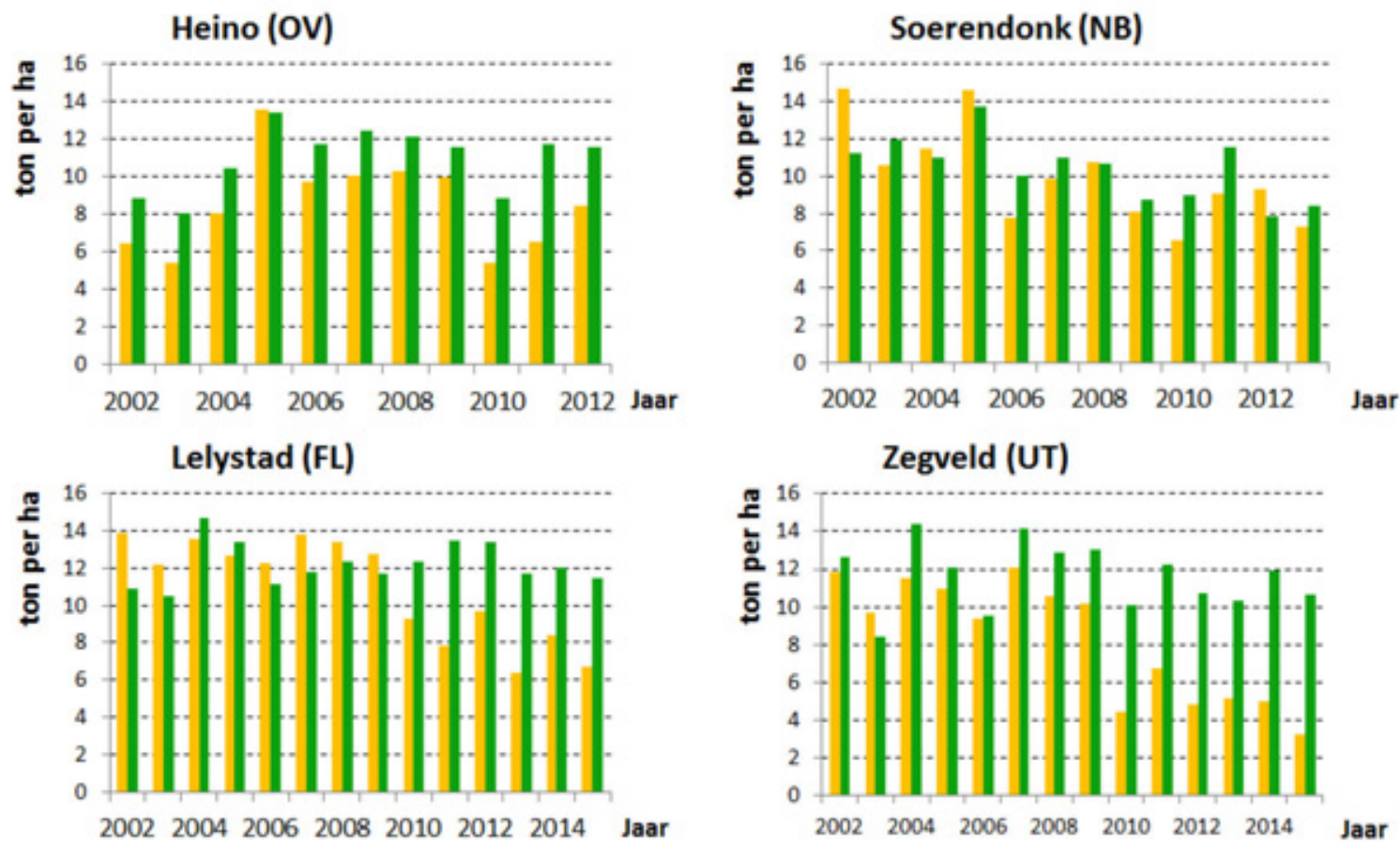

Figuur 3.2 Drogestofopbrengsten van gras bij uitmijnen (gele staven) en evenwichtsbemesting (P00, groene staven), bij een N-bemesting, behorende bij behandeling N300.

\subsection{Gewaskwaliteit}

\subsubsection{Fosforgehalte}

Het gemiddelde P-gehalte in het gras (Figuur 3.3) was op zand en veen bij evenwichtsbemesting circa $10 \%$ lager dan bij een overschot van $40 \mathrm{~kg} \mathrm{P} \mathrm{P}_{5} / \mathrm{ha}$. Het verschil tussen de behandelingen werd niet aantoonbaar groter of kleiner in de tijd. Bij de overstap naar natuurfosfaat in Heino verdween het verschil in P-gehalte tussen de overschotten. Op klei was het verschil in P-gehalte tussen evenwichtsbemesting en $40 \mathrm{~kg}$ overschot circa $3 \%$. 


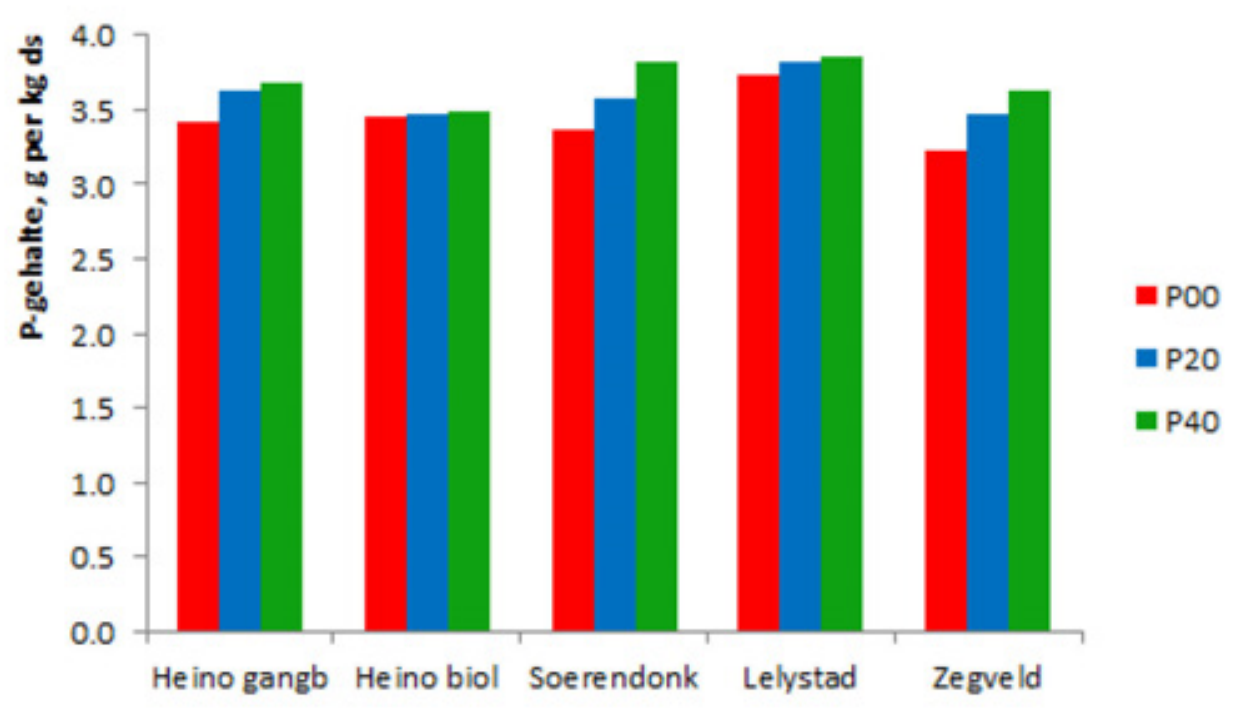

Figuur 3.3 Gemiddeld P-gehalte van gras, gewogen naar snede-opbrengst, bij evenwichtsbemesting (P00), bij een overschotbemesting van $20 \mathrm{~kg}$ fosfaat per ha (P20) of $40 \mathrm{~kg}$ fosfaat per ha (P40), per proeflocatie. Heino gangbaar: 1997-2001; Heino biologisch: 2002-2015, Soerendonk: 1997-2013, Lelystad en Zegveld: 1997-2015.

Het gemiddelde P-gehalte vertoont over de jaren een grote variatie die niet verklaard kan worden door verschillen tussen jaren in de gegeven bemesting. De (weers)omstandigheden tijdens de groei van het gras hebben kennelijk een grote invloed op het P-gehalte. In Figuur 3.4 is ter illustratie het P-gehalte bij evenwichtsbemesting in de proefjaren weergegeven. Zo is het verschil op de beide zandlocaties tussen 2009 en 2010 en op de klei en de veen locatie het verschil tussen 2012 en 2013 meer dan 0,5 g P per kg ds. De verschillen tussen jaren op de overige behandelingen volgden hetzelfde patroon.
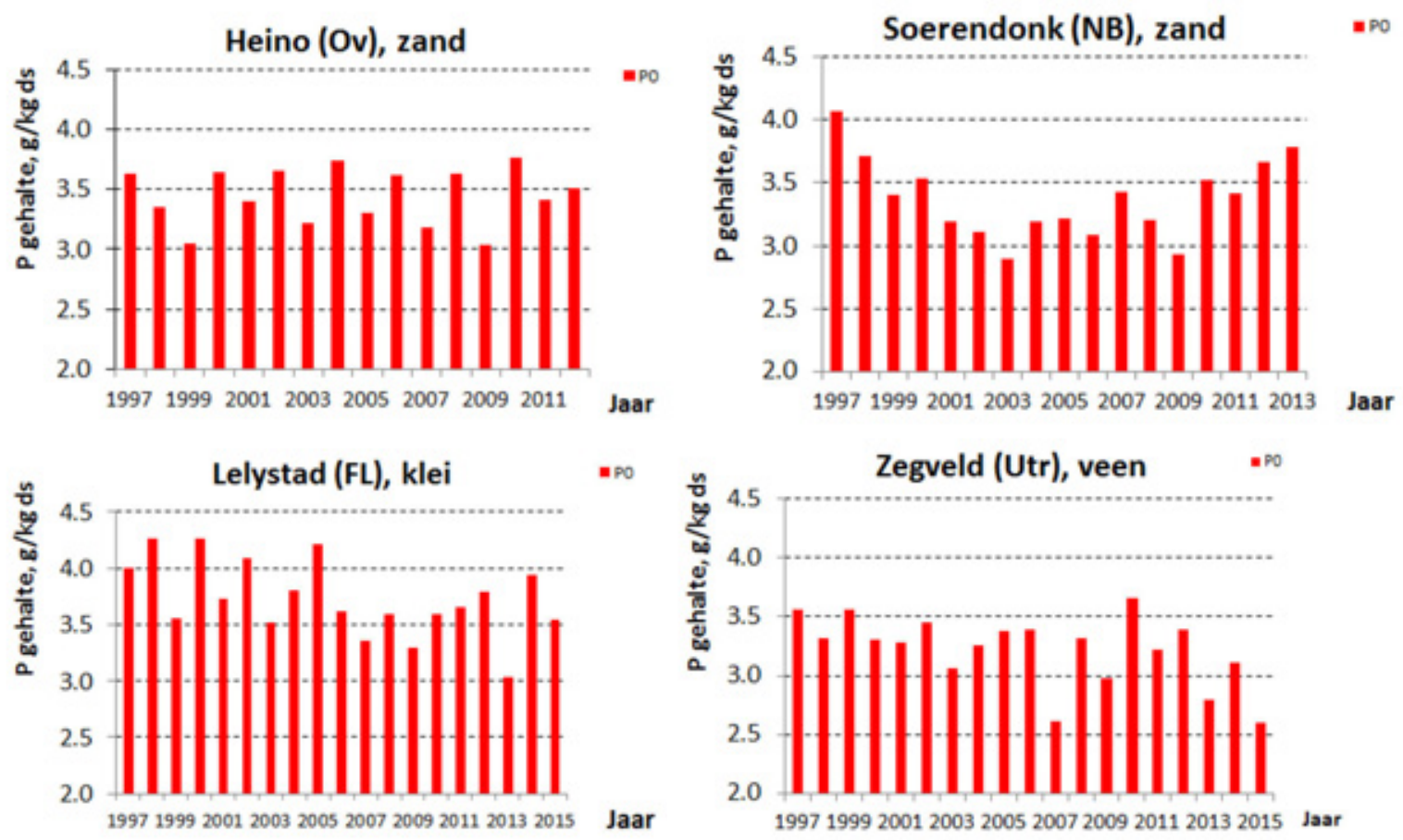

Figuur 3.4 Gemiddeld P-gehalte van gras, gewogen naar snede-opbrengst, bij evenwichtsbemesting (P00), per proeflocatie in de proefjaren. 


\section{Uitmijnen}

Het P-gehalte bij uitmijnen is weergegeven in Figuur 3.5, samen met het P-gehalte van de behandeling N300-P0 (hoge N-trap, P-evenwichtsbemesting). Op de locaties Lelystad en Zegveld zijn de gehalten in alle jaren bij uitmijnen lager dan bij evenwichtsbemesting. Het verschil tussen de plots neemt snel toe op beide locaties. Het P-gehalte bij uitmijnen is in de laatste jaren ongeveer $40 \%$ lager dan bij evenwichtsbemesting. Op de locatie Soerendonk zijn de verschillen kleiner. Op de locatie Heino is er gemiddeld nauwelijks verschil in P-gehalte tussen uitmijnen en evenwichtsbemesting.
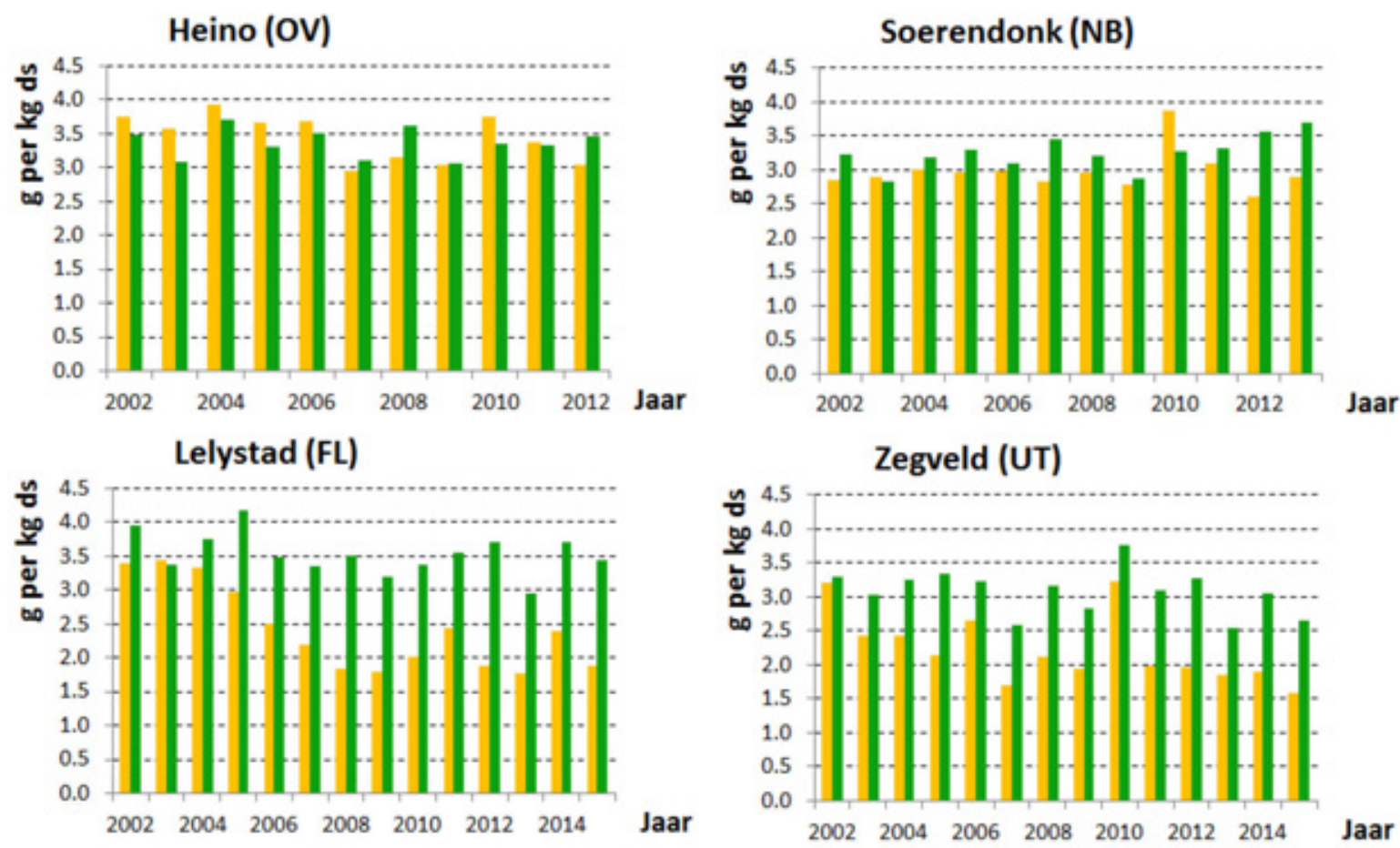

Figuur 3.5 Gemiddeld P-gehalte van gras, gewogen naar snede-opbrengst, bij uitmijnen (gele staven) en evenwichtsbemesting (P00, groene staven), bij een N-bemesting, behorende bij behandeling $N 300$.

\subsubsection{Voederwaarde}

Een aantal voederwaardeparameters is in de eerste elf jaar van de proef bepaald. Omdat er weinig verschillen waren tussen de fosfaatoverschotten, zijn de bepalingen na 2007 niet meer uitgevoerd. De verteringscoëfficiënt is in vitro in het gras gemeten. VEM, DVE en OEB zijn berekend op basis van gemeten parameters, onder andere de verteringscoëfficiënt. Ruw eiwit en ruwe celstof zijn ook na 2007 nog bepaald. Voor de vergelijkbaarheid worden in Figuur 3.6 alle waarden tot en met 2007 weergegeven.

De gemiddelde verteringscoëfficiënt, de VEM-waarde, en het ruwe celstof gehalte in het gras waren niet verschillend tussen de $\mathrm{P}$ - of $\mathrm{N}$-overschotten. De gemiddelde DVE, OEB en ruw eiwitgehalte verschilden wel. Tussen de P-overschotten waren de verschillen niet systematisch. Bij de hogere $\mathrm{N}$-overschotten was de DVE, OEB en het ruw eiwitgehalte systematisch hoger.

In de praktijk zijn er normaal gesproken wel verschillen in VEM en een groter verschil in DVE te vinden tussen N-bemestingsniveaus. Dat is echter mede een gevolg van het verschil in stadium. Grasland met een lagere $\mathrm{N}$-bemesting moet langer groeien om de gewenste doelopbrengst in droge stof te bereiken en heeft daarom een lagere VEM- en DVE-waarde. In deze proef zijn de N-overschotten echter gelijktijdig geoogst en waren de verschillen daardoor kleiner dan in de praktijk waargenomen wordt bij een vergelijkbaar verschil in $\mathrm{N}$-bemesting. De OEB is een maat voor $\mathrm{N}$ die niet benut kan worden door rundvee, maar wel is opgenomen door het gras. In deze proef was de OEB hoger bij een hogere $\mathrm{N}$-bemesting als gevolg van een hogere $\mathrm{N}$-opname door het gewas. In elf jaar fosfaatevenwichtsbemesting is er geen negatief of positief effect gevonden in de voederwaarde. 

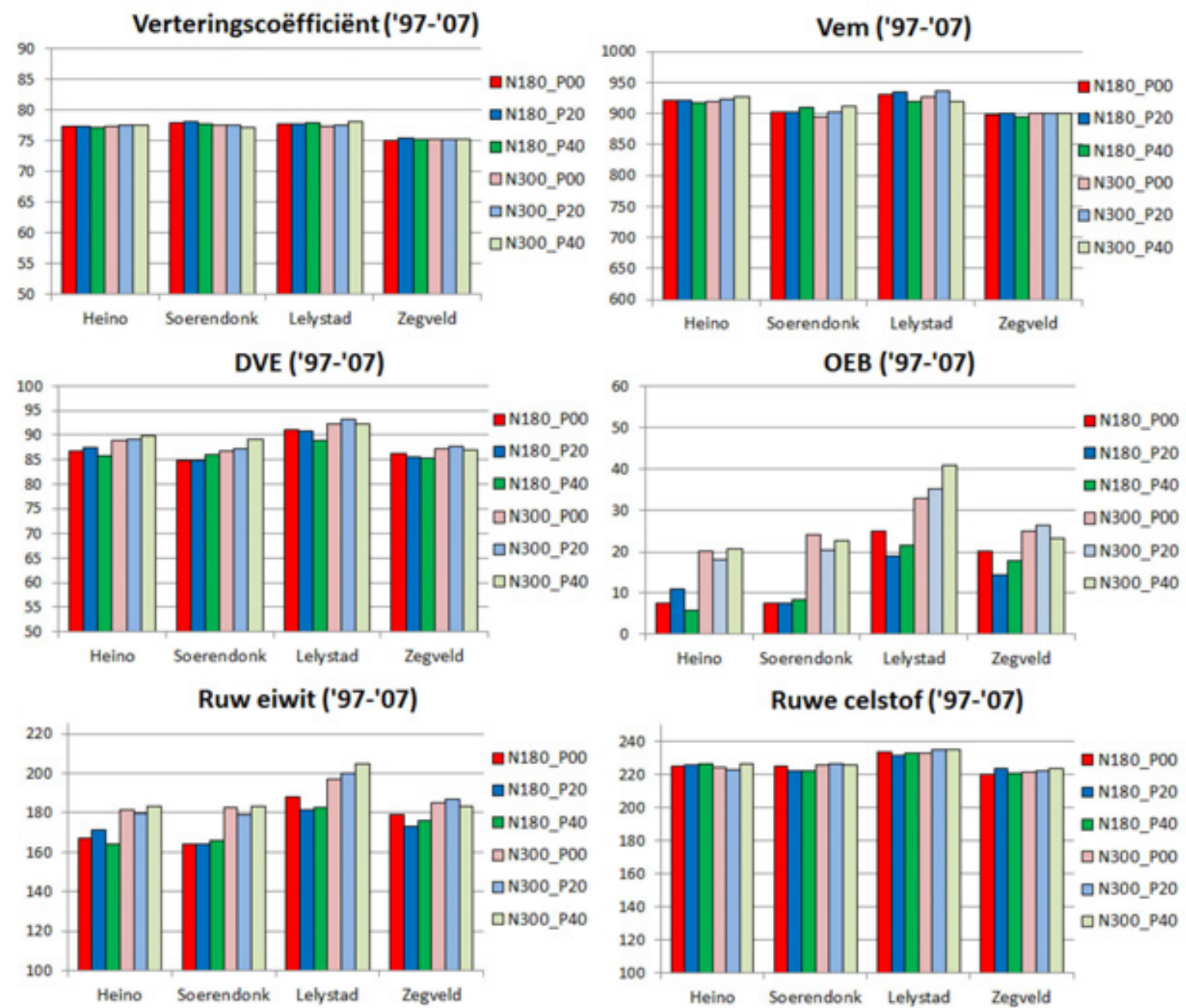

Figuur 3.6 Gemiddeld verteringcoëfficiënt, VEM, DVE, OEB, ruw eiwit, ruwe celstof van gras, gewogen naar snede-opbrengst, bij evenwichtsbemesting (P00), bij een overschotbemesting van $20 \mathrm{~kg}$ fosfaat $\left(\mathrm{P}_{2} \mathrm{O}_{5}\right)$ per ha (P20) of $40 \mathrm{~kg}$ fosfaat per ha (P40), en twee $\mathrm{N}$-overschotten 180 en $300 \mathrm{~kg} \mathrm{~N}$ per ha, per proeflocatie. Heino gangbaar en biologisch is niet onderscheiden.

\subsection{Fosfaatbalans, aanvoer en afvoer}

De fosfaat- en stikstof-balansen op alle plots in de veldproef zijn berekend met:

Netto $\mathrm{P}$ of $\mathrm{N}^{10}$ aanvoer = Aanvoer kunstmest + aanvoer drijfmest - afvoer met maaien - afvoer in gewichtstoename van dieren

vergelijking 1

In Tabel 3.1 zijn de behaalde overschotten in de proef weergegeven. De behaalde $\mathrm{P}_{2} \mathrm{O}_{5}$-overschotten waren op de locaties Heino en Lelystad lager dan gepland en op locaties Soerendonk en Zegveld hoger dan gepland. Het beoogde verschil tussen de overschotten ( $20 \mathrm{~kg} \mathrm{P}_{2} \mathrm{O}_{5}$ ) is redelijk benaderd.

De behaalde $\mathrm{N}$-overschotten zijn aanmerkelijk lager dan de doel-overschotten. Bij het ontwerpen van de proef is uitgegaan van het $\mathrm{N}$-bemestingsniveau en het behaalde $\mathrm{N}$-overschot in de praktijk zoals dat in de voorgaande periode werd behaald. Op de proefvelden bleek echter een lager $\mathrm{N}$-overschot gerealiseerd te worden dan in de praktijk bij vergelijkbare $\mathrm{N}$-bemestingsniveaus. In het eerste documentatierapport (Van Middelkoop et al., 2004) is nagegaan hoe de onderliggende getallen tussen praktijk en proefveld verschilden.

\footnotetext{
${ }^{10} \mathrm{~N}$-aanvoer niet gecorrigeerd voor ammoniakverliezen, $\mathrm{N}$ - en P-opname en -uitscheiding van dieren en gewasverliezen bi beweiding en maaien is een interne stroom en wordt niet meegenomen in de netto-aanvoer of -afvoer.
} 
Tabel 3.1 Gemiddeld stikstof- en fosfaatoverschot over de proefjaren 1997 tot en met 2015 op de vier locaties, in $\mathrm{kg} \mathrm{N}$ en $\mathrm{P}_{2} \mathrm{O}_{5}$ per ha.

\begin{tabular}{lccrr} 
Locatie & \multicolumn{1}{l}{ Heino } & Soerendonk & Lelystad & \\
Behandeling & N-overschot & & & \\
\hline N180 & 45 & 130 & 98 & 110 \\
\hline N300 & 74 & 233 & 185 & 214 \\
\hline P00 & $\mathrm{P}_{2} \mathrm{O}_{5}$-overschot & & & \\
\hline P20 & $-4,7$ & 7,0 & $-9,1$ & 3,5 \\
\hline P40 & 16,9 & 25,1 & 9,8 & 20,2 \\
\hline
\end{tabular}

De aanvoer met fosfaat en stikstof met kunstmest was van tevoren vastgesteld en er is geregistreerd wat daadwerkelijk is toegediend.

De aanvoer van drijfmest is eveneens van tevoren vastgesteld op basis van een verwacht gehalte in de drijfmest. Drijfmest is echter een variabel product. Het fosfaatgehalte in mest varieerde over de jaren en de locaties tussen 0,3 en 2,4 kg $\mathrm{P}_{2} \mathrm{O}_{5}$ per $\mathrm{m}^{3}$. In enkele jaren en locaties was een hoog of een laag gehalte verwacht, maar in sommige situaties week het gehalte ver af van het verwachte gehalte. Daardoor was er variatie in fosfaataanvoer met drijfmest. Deze variatie in aanvoer veroorzaakte mede een variatie in overschot (Figuur 3.7). Dit gold ook voor de aanvoer van $\mathrm{N}$ met drijfmest.

Door de grote variatie in aanvoer en afvoer was het in de eerste jaren moeilijk vast te stellen of de aanvoer verhoogd of verlaagd diende te worden (Figuur 3.8, Figuur 3.9). Na een aantal jaren was het proef-technisch niet verstandig om de aanvoer sterk te veranderen om een trendbreuk in de proef te voorkomen. Er is daardoor na de uitgevoerde proefjaren op de locaties een afwijking ontstaan van het geplande overschot en die bedraagt +7 tot $-9 \mathrm{~kg} \mathrm{P}_{2} \mathrm{O}_{5} /$ ha (Tabel 3.1). In de statistische analyse is hier rekening mee gehouden door de werkelijk uitgevoerde bemestingen en behaalde overschotten te gebruiken als verklarende variabelen. De resultaten werden vervolgens berekend voor strikte fosfaatevenwichtsbemesting (= overschot $0 \mathrm{~kg}$ fosfaat/ha).
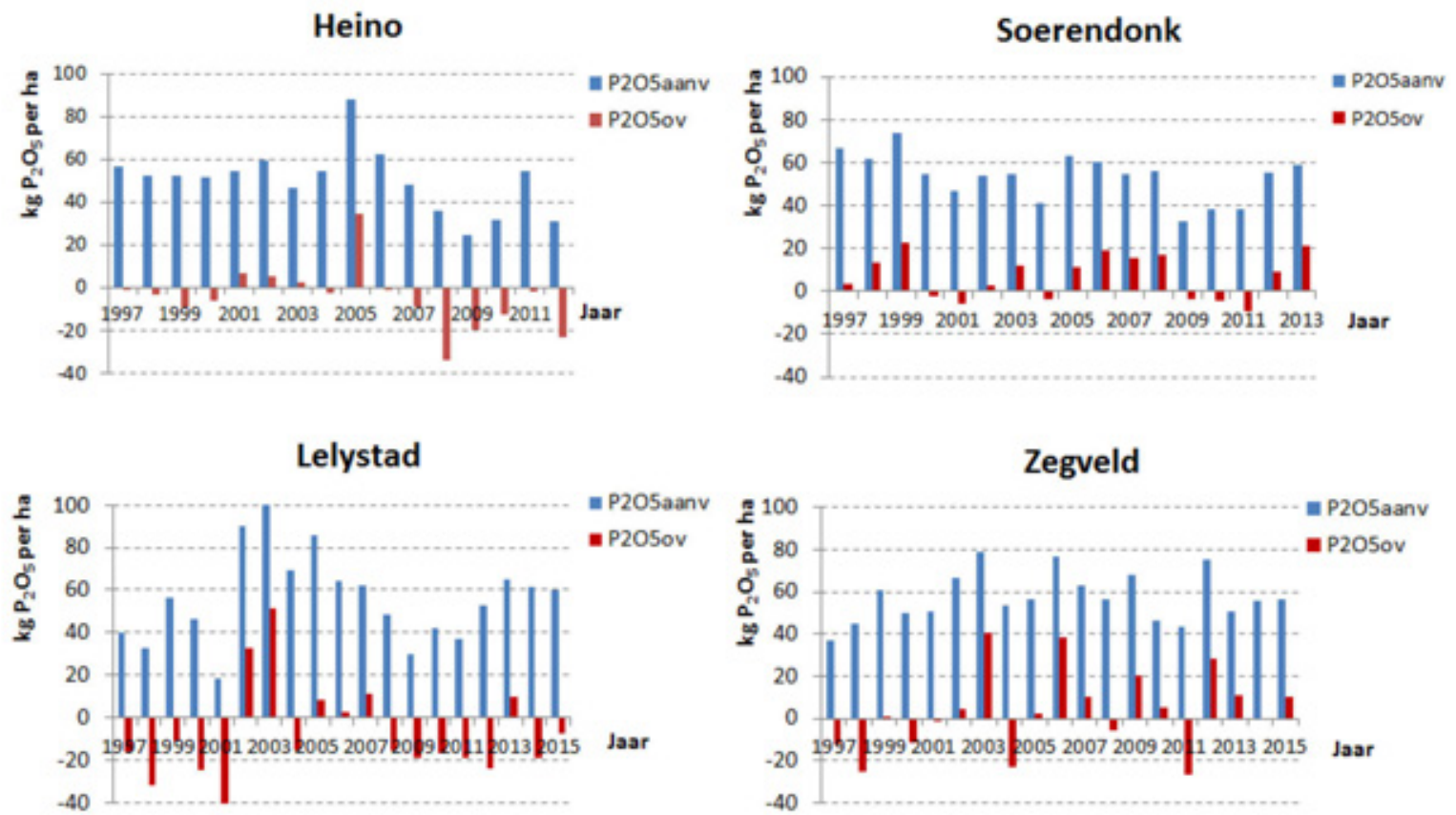

Figuur $3.7 \quad \mathrm{P}_{2} \mathrm{O}_{5}$-aanvoer $\left(\mathrm{P}_{2} \mathrm{O}_{5}\right.$ av) en $\mathrm{P}_{2} \mathrm{O}_{5}$-overschot $\left(\mathrm{P}_{2} \mathrm{O}_{5} \mathrm{OV}\right)$ bij evenwichtsbemesting, gemiddeld over twee $\mathrm{N}$-overschotten. $\mathrm{P}_{2} \mathrm{O}_{5}$-afvoer is het verschil tussen beide waarden. 

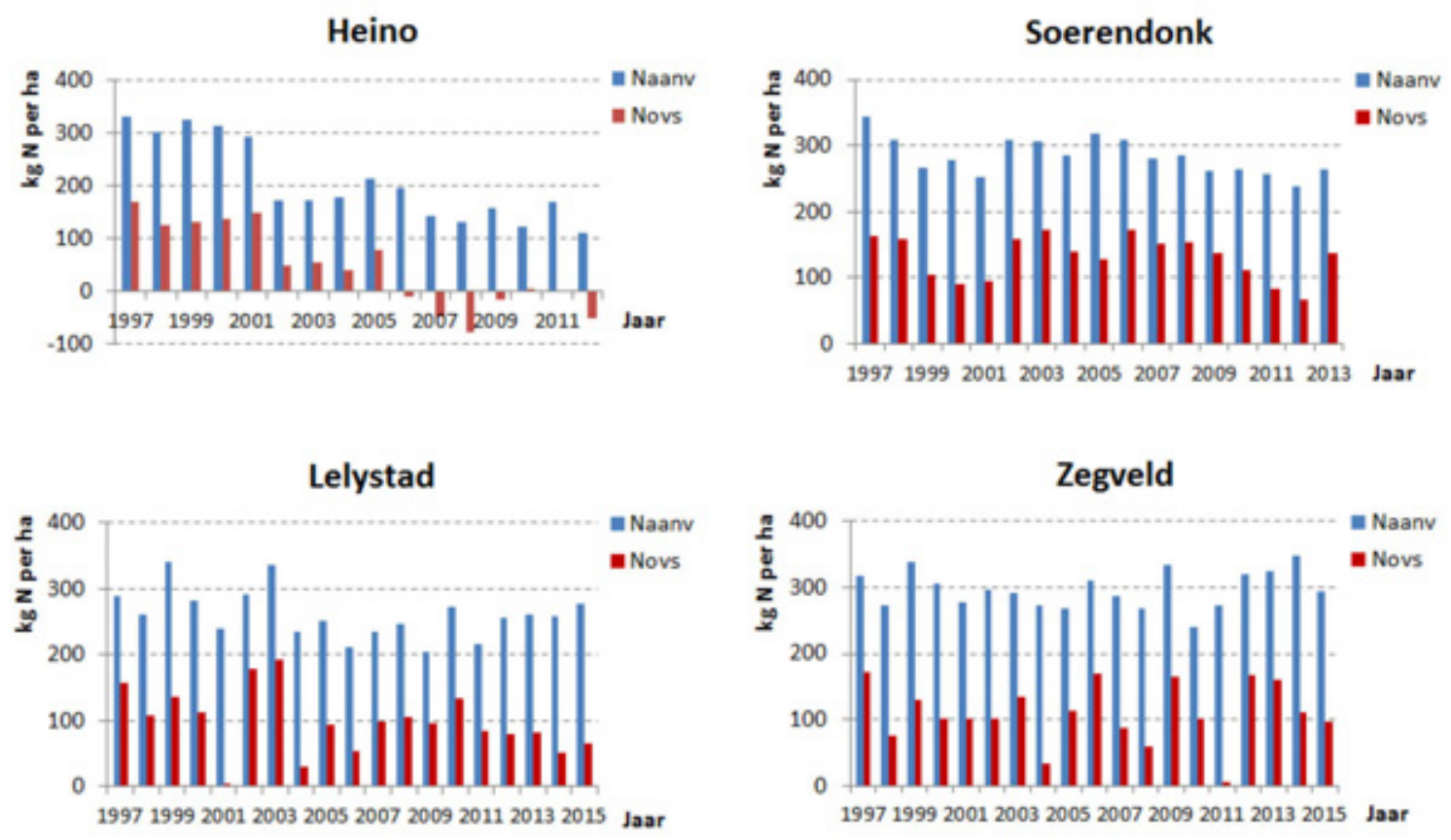

Figuur $3.8 N$-aanvoer (Nav) en N-overschot (Novs) van de $N 180$ behandelingen, gemiddeld over drie $\mathrm{P}_{2} \mathrm{O}_{5}$-overschotten. $\mathrm{N}$-afvoer is het verschil tussen beide waarden.
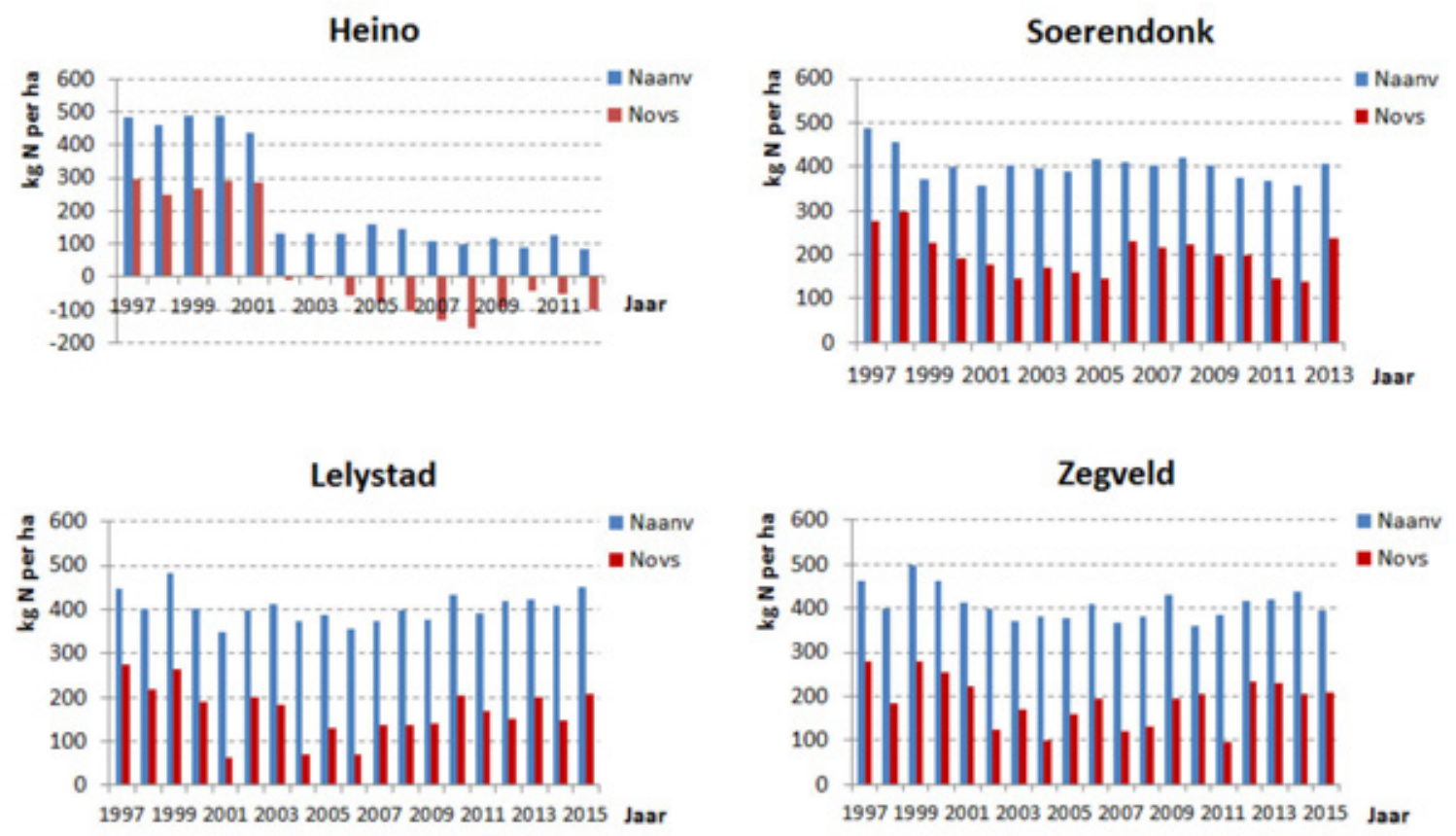

Figuur 3.9 N-aanvoer (Nav) en N-overschot (Novs) op de N300-behandelingen, gemiddeld over drie $\mathrm{P}_{2} \mathrm{O}_{5}$-overschotten. $\mathrm{N}$-afvoer is het verschil tussen beide waarden. Op de locatie Heino is vanaf 2001 klaver aanwezig op de N300-objecten. De door klaver vastgelegde $N$ is niet meegerekend als aanvoer, maar wel als afvoer, waardoor het $\mathrm{N}$-overschot sterk negatief is.

\section{Fosfaatopbrengst}

De fosfaatopbrengst van het gras was gemiddeld over alle locaties $16 \%$ hoger (13 $\mathrm{kg} \mathrm{P}_{2} \mathrm{O}_{5} / \mathrm{ha}$ ) bij een overschot van $40 \mathrm{~kg} \mathrm{P} \mathrm{O}_{5} /$ ha ten opzichte van evenwichtsbemesting (Figuur 3.10). Er kon niet worden aangetoond dat het verschil in fosfaatopbrengst veranderde gedurende de looptijd van de proef, ondanks de opbouw van de fosfaatvoorraad in de bodem bij bemesting met een fosfaatoverschot. Het verschil in opbrengst kwam in alle sneden naar voren. Bij de verandering op Heino van het goed 
oplosbare tripelsuperfosfaat naar het minder oplosbare natuurfosfaat verdween het opbrengstverschil tussen de overschotten grotendeels.

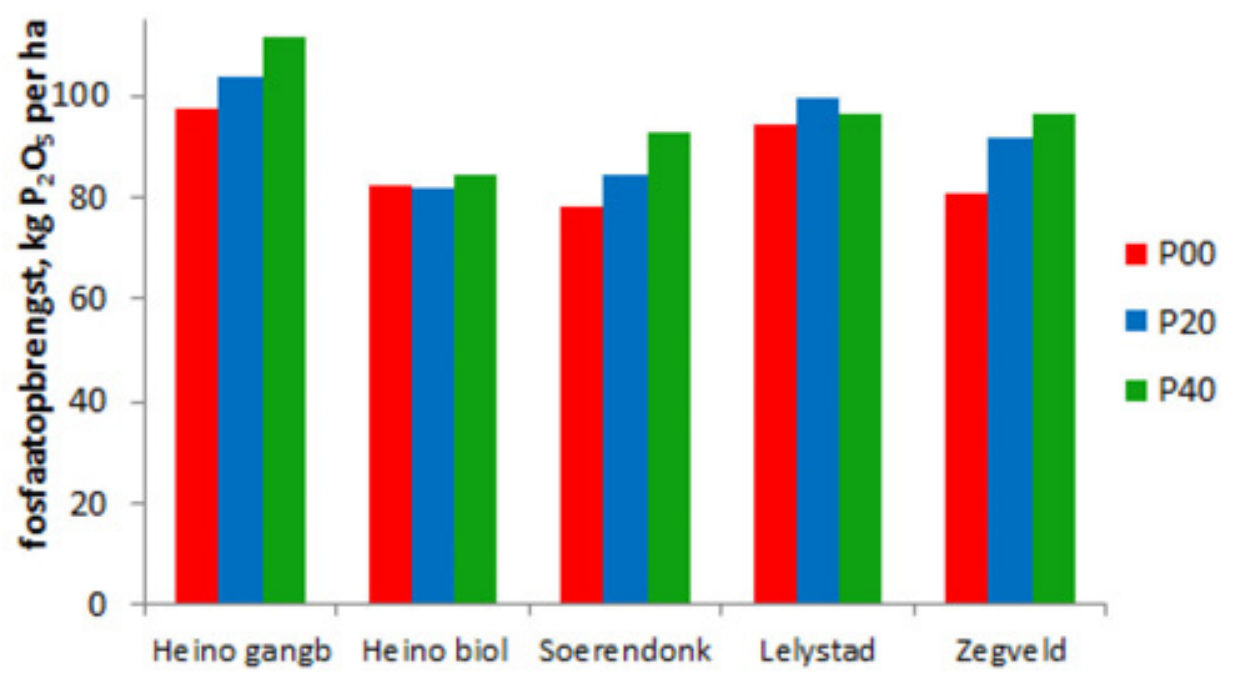

Figuur 3.10 Gemiddelde fosfaatopbrengst van gras bij evenwichtsbemesting (P00), bij een overschotbemesting van $20 \mathrm{~kg}$ fosfaat per ha (P20) of $40 \mathrm{~kg}$ fosfaat per ha (P40), per proeflocatie. Heino gangbaar: 1997-2001; Heino biologisch: 2002-2015, Soerendonk: 1997-2013, Lelystad en Zegveld: 1997-2015.

\section{Vergelijking met gebruiksnorm}

De veldproef is aangelegd in de tijd dat het systeem met een mineralenboekhouding, MINAS, nog in gebruik was als beleidsinstrument. Dit beleidsinstrument ging ervan uit dat N- en P-overschotten die behaald werden op bedrijven onder een opgelegde limiet moesten blijven. Als de overschotten hoger waren dan deze verliesnormen, moest er een heffing betaald worden. De proef heeft daarom behandelingen die gericht zijn op te behalen overschotten. Sinds 2006 is het stelsel van gebruiksnormen in Nederland van toepassing. Er zijn drie gebruiksnormen: gebruiksnorm $\mathrm{N}$ uit dierlijke mest, gebruiksnorm werkzame $\mathrm{N}$, waarbij de $\mathrm{N}$ uit dierlijke mest voor $45 \%$ meetelt op bedrijven met beweiding en voor $60 \%$ op bedrijven die alleen maaien, en de gebruiksnorm voor totale $\mathrm{P}$. De hoeveelheid $\mathrm{N}$ en $\mathrm{P}$ uit dierlijke mest wordt bepaald via forfaitaire normen, afhankelijk van de jaarlijkse melkproductie per melkkoe en vaste normen voor jongvee of via de bedrijfsspecifieke excretienormen (BEX), waarbij de melkveehouder opgeeft hoeveel ruwvoer en krachtvoer door de dieren wordt opgenomen en berekend wordt hoeveel vers gras de dieren opnemen op basis van de energiebehoefte die bij de melkproductie per dier hoort.

In de uitgevoerde veldproef is de gegeven bemesting met dierlijke mest en kunstmest bekend, de uitscheiding in de wei is echter niet gemeten. In de proef is dit een interne kringloop. Om de gegeven bemesting in de proef te vergelijken met gebruiksnormen, is deze uitscheiding in de wei echter een onderdeel van de toegediende hoeveelheid $\mathrm{N}$ en $\mathrm{P}$. Om de vergelijking te maken, is de uitscheiding tijdens beweiding van de dieren, gemiddeld over de proefjaren, op twee manier benaderd:

1. Uitscheiding volgens berekening: van beweide sneden is de opbrengst wel gemeten in de proef, voor de pinken in voorbehandelingsvelden gingen. Deze voorbehandelingsvelden kreeg dezelfde bemesting als de proefvelden. Omdat de dieren eerst een paar dagen in deze voorbehandelingsvelden liepen, was de uiteindelijke opbrengst in de proefvelden bij inscharen hoger omdat er nog enkele groeidagen gemist waren. Ook tijdens beweiding groeide het gras in de proefvelden door. Het aanbod van vers gras aan de dieren was daarom hoger dan gemeten in de beweidingssneden van de proef. Bij beweiding treden echter verliezen op door vertrapping en omdat de dieren de plekken waar mestflatten op liggen, niet vreten. Uitgaande dat de pinken opgenomen hebben wat er tijdens de opbrengstbepaling stond, is de uitscheiding berekend als opbrengst minus toename van $\mathrm{N}$ en $\mathrm{P}$ in lichaamsgewicht. Het resultaat van deze berekening staat in Tabel 3.2. 
2. Uitscheiding volgens forfait ${ }^{11}$ : de uitscheiding van jongvee van $1-2$ jaar $\left(66,9 \mathrm{~kg} \mathrm{~N}\right.$ en $21,9 \mathrm{~kg} \mathrm{P}_{2} \mathrm{O}_{5}$ per dier per jaar) is omgerekend naar een uitscheiding per dag en vermenigvuldigd van het aantal weidedagen dat is gerealiseerd op de plots. Het resultaat van deze berekening staat in Tabel 3.3.

Tabel 3.2 Totaal $N$ werkzaam, totaal $\mathrm{P}_{2} \mathrm{O}_{5}$ en totaal $\mathrm{N}$ uit dierlijke mest, op basis van berekening uit de opbrengst van gras in weidesneden ${ }^{1}(\mathrm{~kg})$.

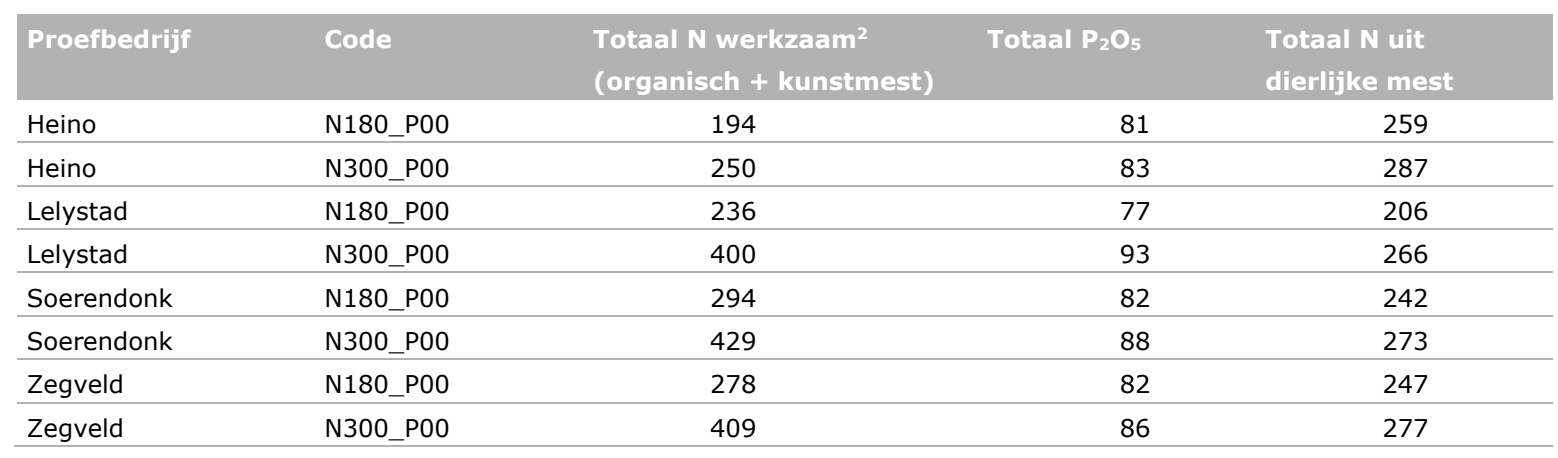

1 Uitscheiding berekend: $\mathrm{N}$ - en P-opbrengst weidesneden minus toename $\mathrm{N}$ en $\mathrm{P}$ in lichaamsgewicht (zie tekst).

2 Werkzame $\mathrm{N}$ uit organische mest: totaal $\mathrm{N}$ maal landbouwkundige werkingscoëfficiënt uit bemestingsadvies grasland.

Tabel 3.3 Totaal $N$ werkzaam, totaal $P_{2} O_{5}$ en totaal $N$ uit dierlijke mest, op basis van forfaitaire uitscheiding van jongvee 1-2 jaar $(\mathrm{kg})$.

\begin{tabular}{|c|c|c|c|c|}
\hline Proefbedrijf & Code & $\begin{array}{l}\text { Totaal N werkzaam }{ }^{1} \\
\text { (organisch + kunstmest) }\end{array}$ & Totaal $\mathrm{P}_{2} \mathrm{O}_{5}$ & $\begin{array}{l}\text { Totaal } \mathbf{N} \text { uit dierlijke } \\
\text { mest }\end{array}$ \\
\hline Heino & N180_P00 & 184 & 84 & 237 \\
\hline Lelystad & N180_P00 & 275 & 109 & 293 \\
\hline Lelystad & N300_P00 & 418 & 120 & 307 \\
\hline Soerendonk & N300_P00 & 429 & 109 & 272 \\
\hline Zegveld & N180_P00 & 282 & 98 & 256 \\
\hline Zegveld & N300_P00 & 405 & 99 & 267 \\
\hline
\end{tabular}

1 Werkzame $\mathrm{N}$ uit organische mest: totaal $\mathrm{N}$ maal landbouwkundige werkingscoëfficiënt uit bemestingsadvies grasland.

Op alle locaties is de fosfaatuitscheiding volgens forfaitaire normen hoger dan de fosfaatuitscheiding volgens berekening. Verwacht mag worden dat de forfaitaire uitscheiding in werkelijkheid niet gehaald kon worden op basis van de grasopbrengst, daarvoor was niet voldoende $\mathrm{P}$ in gras beschikbaar tijdens beweiding.

De $\mathrm{N}$-uitscheiding volgens berekening en volgens forfait zijn met elkaar vergelijkbaar op Soerendonk en Zegveld, op Heino is de berekende uitscheiding hoger, op Lelystad lager. Op de Locaties Lelystad, Soerendonk en Zegveld is de orde van grootte van zowel de totale uitscheiding als de werkzame stikstof op het lage $\mathrm{N}$-overschot vergelijkbaar met de gebruiksnorm, op Heino op het hoge $\mathrm{N}$ overschot. Bij Heino is dit een gevolg van het biologische proefveld management.

De bemesting van de N180 plots zijn voor de proefvelden met een gangbaar management redelijk vergelijkbaar met de huidige gebruiksnormen in Nederland.

Uitgaande van een berekende uitscheiding is op alle plots met evenwichtsbemesting de totale toediening van $\mathrm{P}_{2} \mathrm{O}_{5}$ gemiddeld $10 \mathrm{~kg} \mathrm{P} \mathrm{P}_{5}$ lager dan de fosfaatgebruiksnorm bij klasse neutraal, met uitzondering van het object N300-P00 op locatie Lelystad. Uitgaande van een forfaitaire uitscheiding is op alle plots met evenwichtsbemesting de totale toediening van $\mathrm{P}_{2} \mathrm{O}_{5}$ hoger dan de gebruiksnorm, met uitzondering van locatie Heino.

\footnotetext{
11 Uitvoeringsregeling Meststoffenwet
} 
Conclusie: de bemesting van de plots met fosfaatevenwichtsbemesting zijn redelijk vergelijkbaar met de huidige fosfaatgebruiksnormen in Nederland.

Fosfaatopbrengst bij uitmijnen
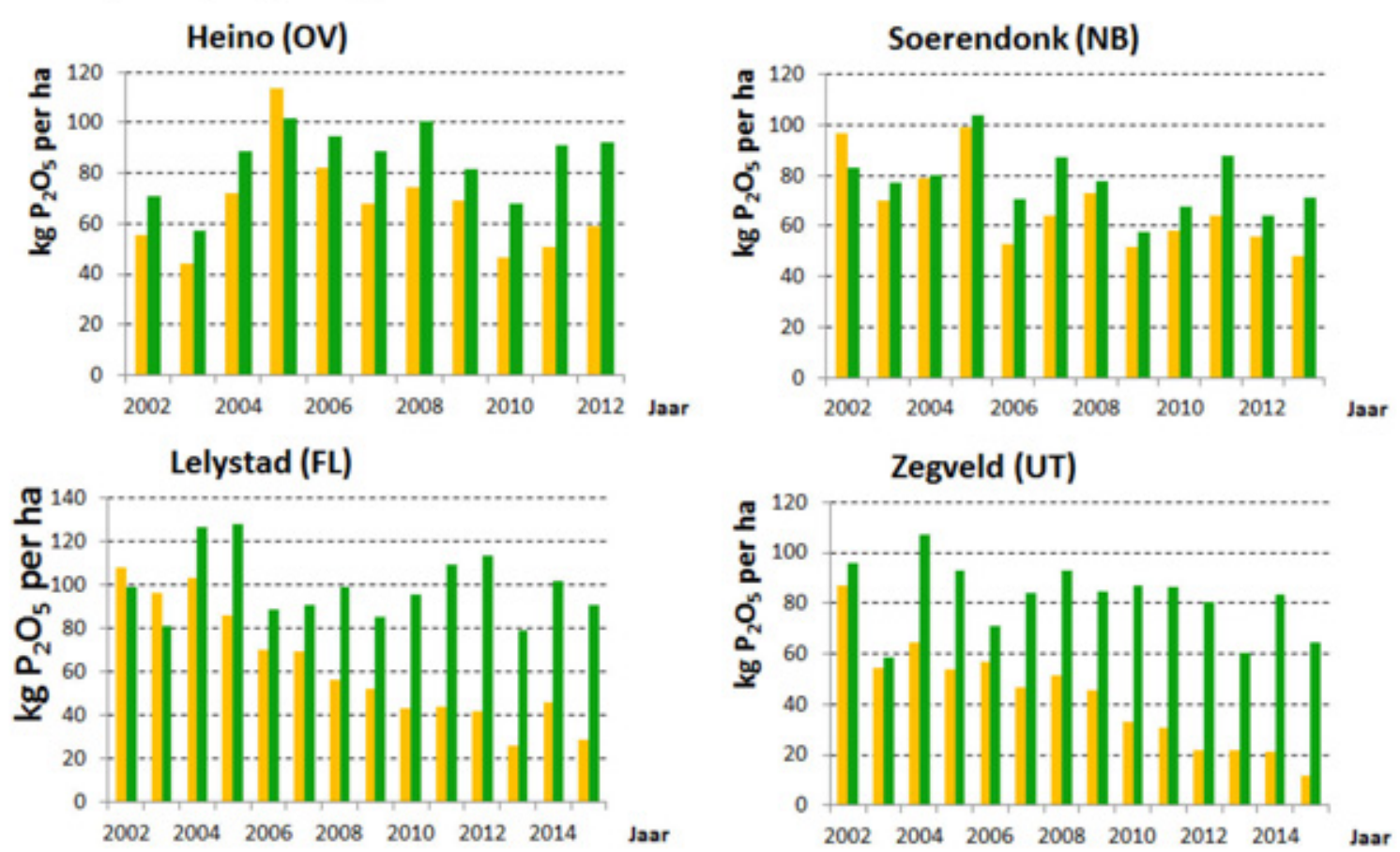

Figuur 3.11 Fosfaatopbrengst van gras bij uitmijnen (gele staven) en evenwichtsbemesting (P00, groene staven), bij een N-bemesting, behorende bij behandeling $N 300$.

De fosfaatopbrengst bij uitmijnen is weergegeven in Figuur 3.11, samen met de fosfaatopbrengst van de behandeling N300-P0 (hoge N-trap, P-evenwichtsbemesting).

Op de locaties Lelystad en Zegveld dalen de fosfaatopbrengsten bij uitmijnen snel. Vanaf het derde jaar is de fosfaatopbrengst al circa $20 \mathrm{~kg} \mathrm{P}_{2} \mathrm{O}_{5} / \mathrm{ha}$ lager dan bij evenwichtsbemesting en daalt naar een niveau van circa $20 \mathrm{~kg} \mathrm{P}_{2} \mathrm{O}_{5} / \mathrm{ha}$. Op de zandlocaties daalt de opbrengst naar circa $50 \mathrm{~kg} \mathrm{P}_{2} \mathrm{O}_{5} / \mathrm{ha}$.

Rigoureus uitmijnen door volledig te stoppen met toediening van fosfaat (Figuur 3.11) lijkt hiermee op lange termijn (> 10 jaar) geen efficiënte methode om grote hoeveelheden fosfaat af te voeren uit de bodem van grasland. Na circa 5 jaar neemt de fosfaatonttrekking op grasland sterk af.

\subsection{Bodem}

De fosfaattoestand van de bodem van grasland is jaarlijks gemonitord aan de hand van standaard fosfaatbodemtesten (P-Al-getal, $\mathrm{Pw}$-getal (data niet gegeven), $\mathrm{P}-\mathrm{CaCl}_{2}$ ) en onderzoeksmethoden (P-totaal, $\mathrm{P}$-ox, $\mathrm{P}$-organisch). De getoonde $\mathrm{P}$-gehalten in de bodem zijn in alle gevallen gemiddelden van de twee percelen met gelijke $\mathrm{P}$ - maar verschillende $\mathrm{N}$-overschotten. Het verloop in $\mathrm{Pw}$-getal is niet opgenomen in deze rapportage, omdat deze een vergelijkbare trend geeft als verloop in $\mathrm{P}-\mathrm{AL}$, $\mathrm{maar}$ is wel beschikbaar in eerdere publicaties (Van der Salm et al., 2017).

\subsubsection{Standaard bodemtesten}

\section{P-Al-getal}

Figuur 3.12 toont het verloop in het P-Al-getal in de $0-10 \mathrm{~cm}$ bodemlaag bij evenwichts- en overschotbemesting. Tabel 3.4 toont het initiële en huidige P-Al-getal $(0-10 \mathrm{~cm})$ bij evenwichtsbemesting en overschotbemesting. Het P-Al-getal in de $0-10 \mathrm{~cm}$ bodemlaag is berekend als het gemiddelde van het P-Al-getal in de 0-5 en 5-10 cm bodemlaag. Voor figuren met het verloop in P-Al-getal in de afzonderlijke bodemlagen wordt verwezen naar eerdere publicaties (Van der Salm et al., 2017; Van Middelkoop et al., 2016). Het P-Al-getal in de onderliggende bodemlagen (10-20, 
20-30 cm) is niet getoond, omdat op deze diepten geen significante veranderingen in P-Al-getal optreden (Van der Salm et al., 2017).

Bij aanvang van de veldproef bevonden alle percelen zich in de fosfaattoestand 'neutraal'. Evenwichtsbemesting leidt op zandgronden tot een afname in het P-Al-getal in de 0-10 cm bodemlaag. Op Heino neemt het P-Al-getal over een periode van 15 jaar af van 42 tot 27, waardoor de fosfaattoestand verandert van 'neutraal' naar 'laag'. Op Soerendonk, waar de proef is uitgevoerd op een bodemchemisch goed vergelijkbare bodem, neemt het P-Al-getal af van 37 naar 32. De minder sterke afname in P-Al-getal op Soerendonk is in overeenstemming met de verschillen in de daadwerkelijk gerealiseerde P-overschotten op beide locaties (par. 3.3). Bij evenwichtsbemesting werd op Heino gemiddeld over 16 jaar een fosfaattekort van 4,7 kg $\mathrm{P}_{2} \mathrm{O}_{5} /$ ha/jaar gerealiseerd, terwijl op Soerendonk een fosfaatoverschot werd gerealiseerd van 7,0 kg $\mathrm{P}_{2} \mathrm{O}_{5} / \mathrm{ha} / \mathrm{jaar}$ (Tabel 3.4) over 17 jaar. Op de zeekleigrond (Lelystad) blijft het P-Al-getal bij evenwichtsbemesting gehandhaafd. Op de veengrond toont het P-Al-getal een sterk temporele variatie waardoor de fosfaattoestand (laag/neutraal) van deze grond van jaar tot jaar kan verschillen; de afnemende trend is niet statistisch significant.

Bij bemesting met een fosfaatoverschot van 20 of $40 \mathrm{~kg} \mathrm{P} \mathrm{O}_{5} / \mathrm{ha} / \mathrm{jaar}$ is het P-Al-getal op alle grondsoorten significant hoger dan bij evenwichtsbemesting (Van Middelkoop et al., 2016). Op Soerendonk en Zegveld blijft het P-Al-getal bij een fosfaatoverschot van $20 \mathrm{~kg} \mathrm{P}_{2} \mathrm{O}_{5} / \mathrm{ha} / \mathrm{jaar}$ gehandhaafd. Op Heino is hiervoor een fosfaatoverschot van circa $40 \mathrm{P}_{2} \mathrm{O}_{5} / \mathrm{ha} / \mathrm{jaar}$ nodig. Op de kleigrond wordt fosfaattoestand 'neutraal' gehandhaafd bij evenwichtsbemesting.
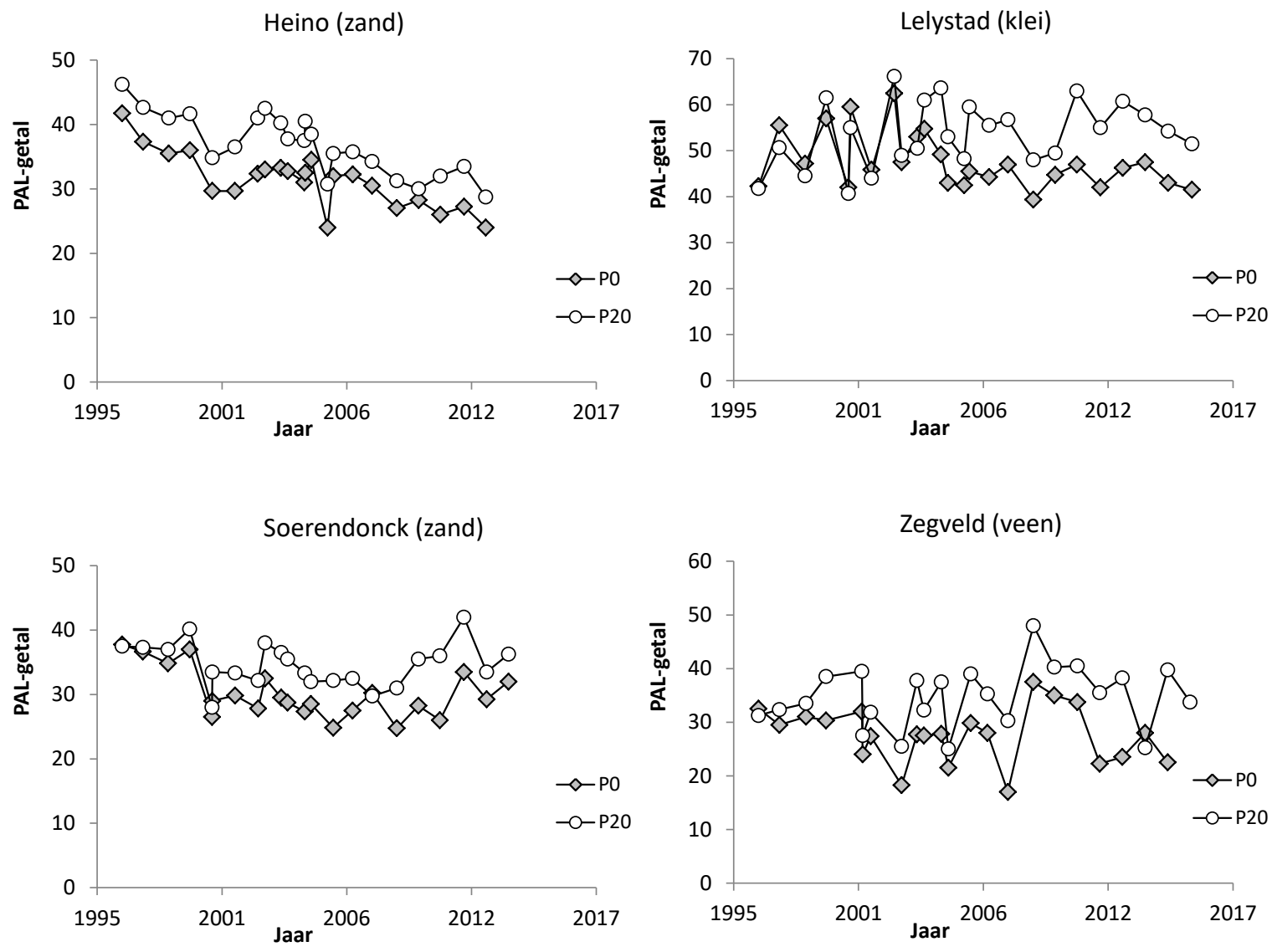

Figuur $3.12 P$-Al-getal in de $0-10 \mathrm{~cm}$ bodemlaag bij evenwichtsbemesting (PO) en bij een fosfaatoverschot van $20 \mathrm{~kg} \mathrm{P}_{2} \mathrm{O}_{5} / \mathrm{ha} / \mathrm{j}$ (P20) op de vier proeflocaties. 
Tabel $3.4 P$-Al-getal ( $m g P_{2} O_{5} / 100 \mathrm{~g}$ ) in 1996 en 2016 en fosfaattoestand (laag $(L)$, neutraal $(N)$, hoog $(H)$ ) op de graspercelen bij evenwichtsbemesting $(P 0)$ en bij een fosfaatoverschot van respectievelijk 20 en $40 \mathrm{~kg} \mathrm{P}_{2} \mathrm{O}_{2} /$ ha/jaar (P2O, P40).

\begin{tabular}{|c|c|c|c|c|}
\hline \multirow[t]{2}{*}{ Locatie } & \multirow[t]{2}{*}{ P-Al-getal 1996} & \multicolumn{3}{|c|}{ P-Al-getal in 2016} \\
\hline & & PO & P20 & P40 \\
\hline Zand (Heino) & $43(\mathrm{~N})$ & $26(\mathrm{~L} / \mathrm{N})$ & $31(N)$ & $42(N)$ \\
\hline Zeeklei (Lelystad) & $48(N)$ & $44(N)$ & $55(\mathrm{H})$ & $67(H)$ \\
\hline Veen (Zegveld) & $33(N)$ & $24(L)$ & $33(N)$ & $43(N)$ \\
\hline
\end{tabular}

a P-Al-getal in de 0-10 cm bodemlaag is berekend als gemiddelde van het P-Al-getal in de 0-5 en 5-10 bodemlaag. Het initiële P-Al-getal is berekend als het gemiddelde over 1996 en 1997. Het huidige P-Al-getal is berekend als het gemiddelde P-Al-getal in de laatste drie meetjaren (Heino: 2010-2012; Soerendonk: 2011-2013; Lelystad en Zegveld: 2013-2015

\section{$\mathrm{P}-\mathrm{CaCl}_{2}$}

Figuur 3.13 toont het verloop in de $\mathrm{P}-\mathrm{CaCl}_{2}$-concentratie in de $0-5 \mathrm{~cm}$ bodemlaag bij evenwichts- en overschotbemesting. De gemiddelde $\mathrm{P}-\mathrm{CaCl}_{2}$-concentraties zijn opgenomen in Tabel 3.5. Voor uitkomsten van de statistische analyse en figuren met het verloop van de $\mathrm{P}-\mathrm{CaCl}_{2}$-concentratie in de 5-10 cm bodemlaag wordt verwezen naar Van Middelkoop et al., 2016.

De P- $\mathrm{CaCl}_{2}$-concentratie toont op alle locaties een sterke daling gedurende de eerste jaren na aanvang van de proef. Deze daling treedt zowel op bij evenwichtsbemesting als bij overschotbemesting. Vanaf 2004 zijn P-CaCl${ }_{2}$-concentraties jaarlijks gemeten. Na 2004 wordt geen afnemende trend in $\mathrm{P}-\mathrm{CaCl}_{2}-$ concentraties bij evenwichtsbemesting waargenomen. Het afleiden van een dergelijke trend wordt echter bemoeilijkt door de grote temporele variatie in $\mathrm{P}-\mathrm{CaCl}_{2}$-concentraties.

Bij overschotbemesting zijn de gemiddelde $\mathrm{P}-\mathrm{CaCl}_{2}$-concentraties (vanaf 2004) hoger dan bij evenwichtsbemesting (niet statistisch significant), met uitzondering van Heino (Tabel 3.5). Op Heino hebben percelen met evenwichts- en overschotbemesting een gelijke $\mathrm{P}-\mathrm{CaCl}_{2}$-waarde doordat op deze locatie sinds 2002 gebruik wordt gemaakt van het niet in wateroplosbare natuurfosfaat voor bemesting van de fosfaatoverschotten (biologische bedrijfsvoering). De $\mathrm{P}-\mathrm{CaCl}_{2}$-concentraties blijven, landbouwkundig gezien, voldoende hoog. $\mathrm{Bij}$ een landbouwkundige interpretatie van de $\mathrm{P}-\mathrm{CaCl}_{2}-$ waarden moet echter rekening gehouden worden met het feit dat $\mathrm{P}-\mathrm{CaCl}_{2}$-concentraties bepaald zijn in de $0-5 \mathrm{~cm}$ bodemlaag en daardoor niet zonder meer vergeleken kunnen worden met $\mathrm{P}-\mathrm{CaCl}_{2}-\mathrm{waarden}$ uit bemestingsadviezen welke veelal zijn gebaseerd op analyses op de 0-10 cm bodemlaag.

P-CaCl 2 -concentraties tonen een sterke temporele variatie. Onder evenwichtsbemesting wordt na 2004 geen afname in $\mathrm{P}-\mathrm{CaCl}_{2}$ waargenomen. 

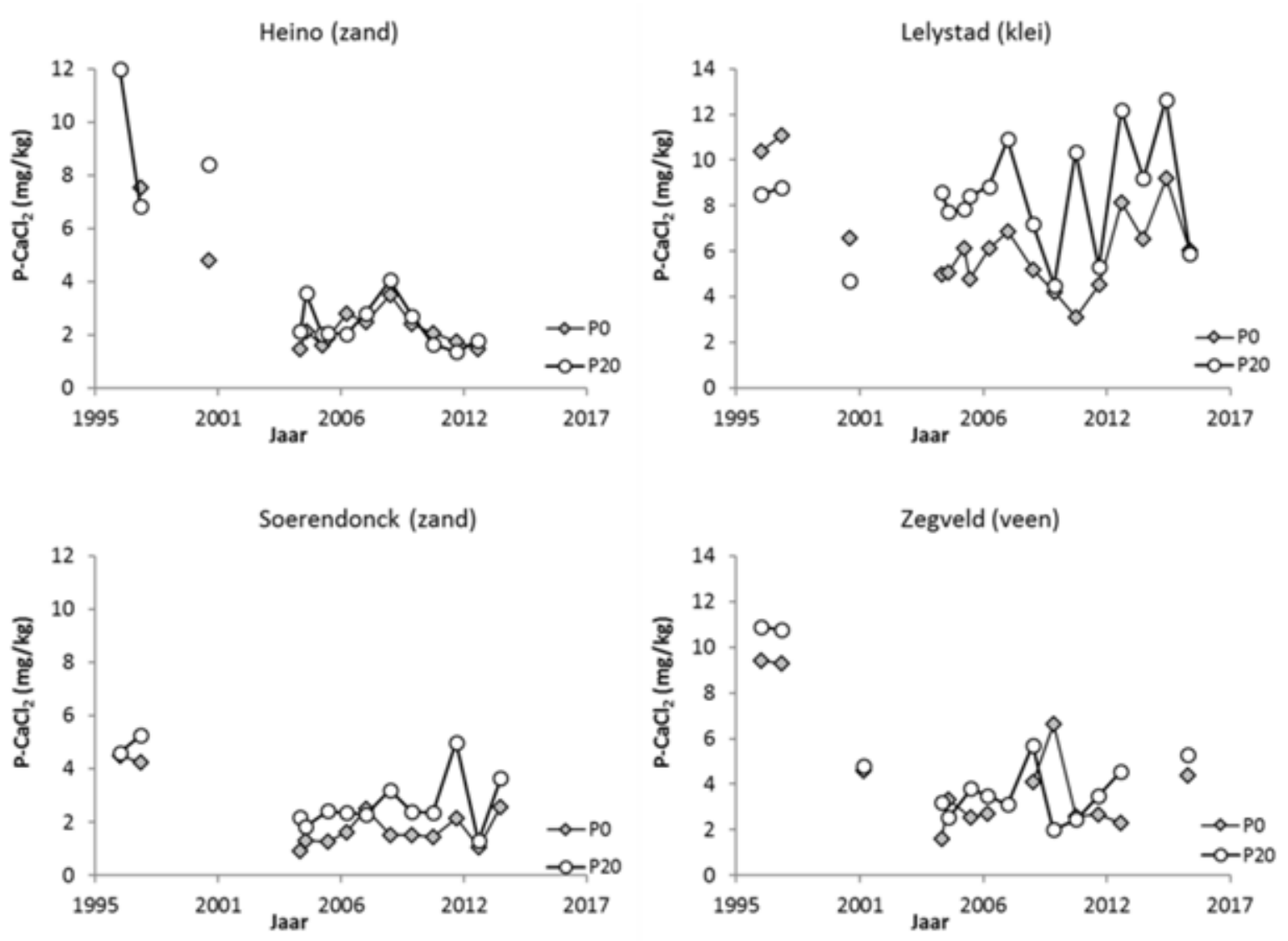

Figuur $3.13 \mathrm{P}-\mathrm{CaCl}_{2}$-concentratie in de $0-5 \mathrm{~cm}$ bodemlaag bij evenwichtsbemesting (PO) en overschotbemesting (P20, $20 \mathrm{~kg} \mathrm{P}_{2} \mathrm{O}_{5} / \mathrm{ha} / \mathrm{j}$ ) op de vier proeflocaties.

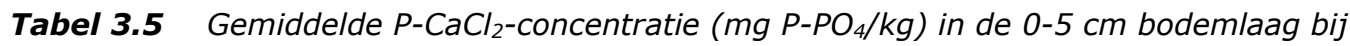
evenwichtsbemesting (PO) en een fosfaatoverschot van respectievelijk 20 en $40 \mathrm{~kg} P_{2} \mathrm{O}_{2} / \mathrm{ha} / \mathrm{jaar}$ (P20, P40).

\begin{tabular}{|c|c|c|c|c|c|}
\hline \multirow[t]{3}{*}{ Grondsoort (locatie) } & \multirow{3}{*}{$\begin{array}{l}\text { Diepte } \\
\mathrm{cm}\end{array}$} & \multirow{3}{*}{$\begin{array}{l}\mathrm{P}-\mathrm{CaCl}_{2} \\
1996\end{array}$} & \multicolumn{3}{|l|}{$\mathrm{P}-\mathrm{CaCl}_{2}$} \\
\hline & & & \multicolumn{3}{|l|}{ 2004-2015 } \\
\hline & & & PO & P20 & P40 \\
\hline Zand (Soerendonk) & $0-5$ & 4,7 & $1,6( \pm 0.6)^{*}$ & $2,7( \pm 1.1)$ & $3,6( \pm 1.4)$ \\
\hline Zeeklei (Lelystad) & $0-5$ & 8,3 & $5,9( \pm 2.1)$ & $8,6( \pm 2.7)$ & $8,0( \pm 3.5)$ \\
\hline
\end{tabular}

a De gemiddelde P-CaCl 2 -concentratie in de periode 2004-2011 (Heino), 2004-2013 (Soerendonk) en 2004-2015 (Lelystad, Zegveld). Vanaf 2004 zijn metingen van $\mathrm{P}-\mathrm{CaCl}_{2}$ jaarlijks uitgevoerd.

b Een * geeft aan dat verschillen in $\mathrm{P}-\mathrm{CaCl}_{2}$ tussen verschillende fosfaatbehandelingen statistisch significant zijn (REML-analyse, Van Middelkoop et al., 2016).

\subsubsection{Onderzoek bodemtesten}

\section{P-totaal}

Figuur 3.14 toont het P-totaal gehalte in de $0-10 \mathrm{~cm}$ bodemlaag bij evenwichts- en overschotbemesting in de periode 1996-2015. Bij evenwichtsbemesting blijft P-totaal op de zandgronden in de tijd constant. Op kleigrond neemt P-totaal in de bovengrond toe, wat wijst op opname van fosfaat uit bodemlagen dieper dan $10 \mathrm{~cm}$. Door het afsterven van wortels en gras draagt dit bij aan de opbouw van fosfaat (en organische stof) in de bovengrond. Op veengrond is een toenemende trend in P-totaal zichtbaar (niet statistisch significant), wat kan duiden op inklinking. In de onderliggende bodemlaag (10-30) blijft P-totaal bij evenwichtsbemesting op alle grondsoorten constant. 

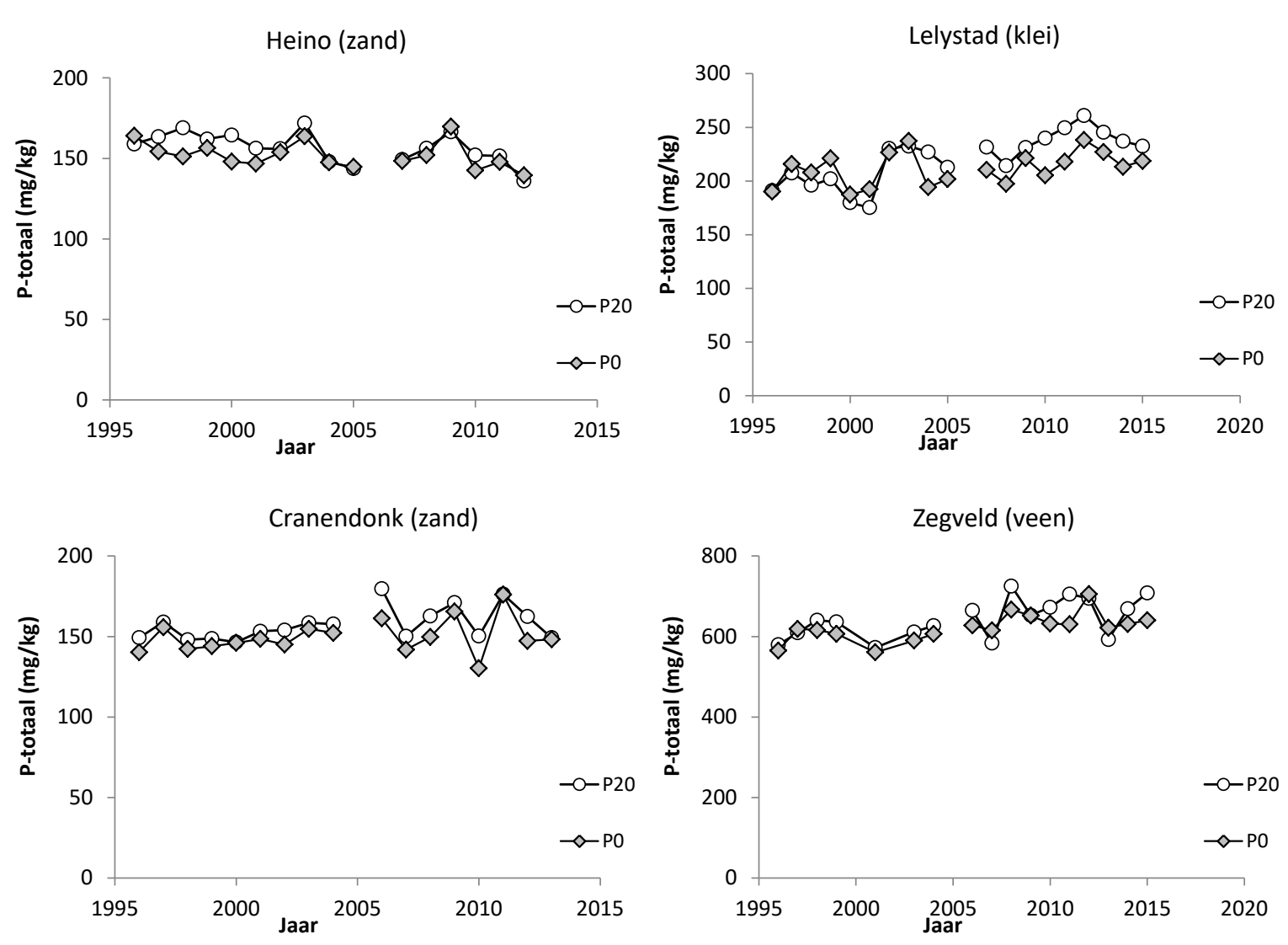

Figuur 3.14 P-totaal in de $0-10 \mathrm{~cm}$ bodemlaag bij evenwichtsbemesting $(P 0)$ en overschotbemesting (P20, $20 \mathrm{~kg} \mathrm{P}_{2} \mathrm{O}_{5} / \mathrm{ha} / \mathrm{j}$ ) op de vier proeflocaties.

\section{P-ox en P-verzadigingsgraad}

Het P-ox-gehalte is een maat voor de hoeveelheid fosfaat gebonden aan minerale bodemdeeltjes (ijzeroxiden, kleideeltjes). Deze fosfaatfractie bestaat grotendeels uit ortho-fosfaat (ortho-P) en deels uit organisch fosfaat. Op alle grondsoorten worden een sterke en statistisch significante daling in het P-ox gehalte waargenomen (Van der Salm et al., 2017). De P-ox gehalten in de bovengrond $(0-10 \mathrm{~cm})$ op de zandgronden in Heino en Soerendonk nemen gedurende 15 jaar evenwichtsbemesting af met 30 en 15\% ten opzichte van de initiële gehalten (Figuur 3.15). Op de proefvelden Lelystad en Zegveld neemt het P-ox-gehalte met 16 en $19 \%$ af over een periode van 19 jaar. P-ox toont een continu dalende trend, wat aangeeft dat er na 15-19 jaar evenwichtsbemesting nog geen nieuwe evenwichtssituatie is ingesteld. 

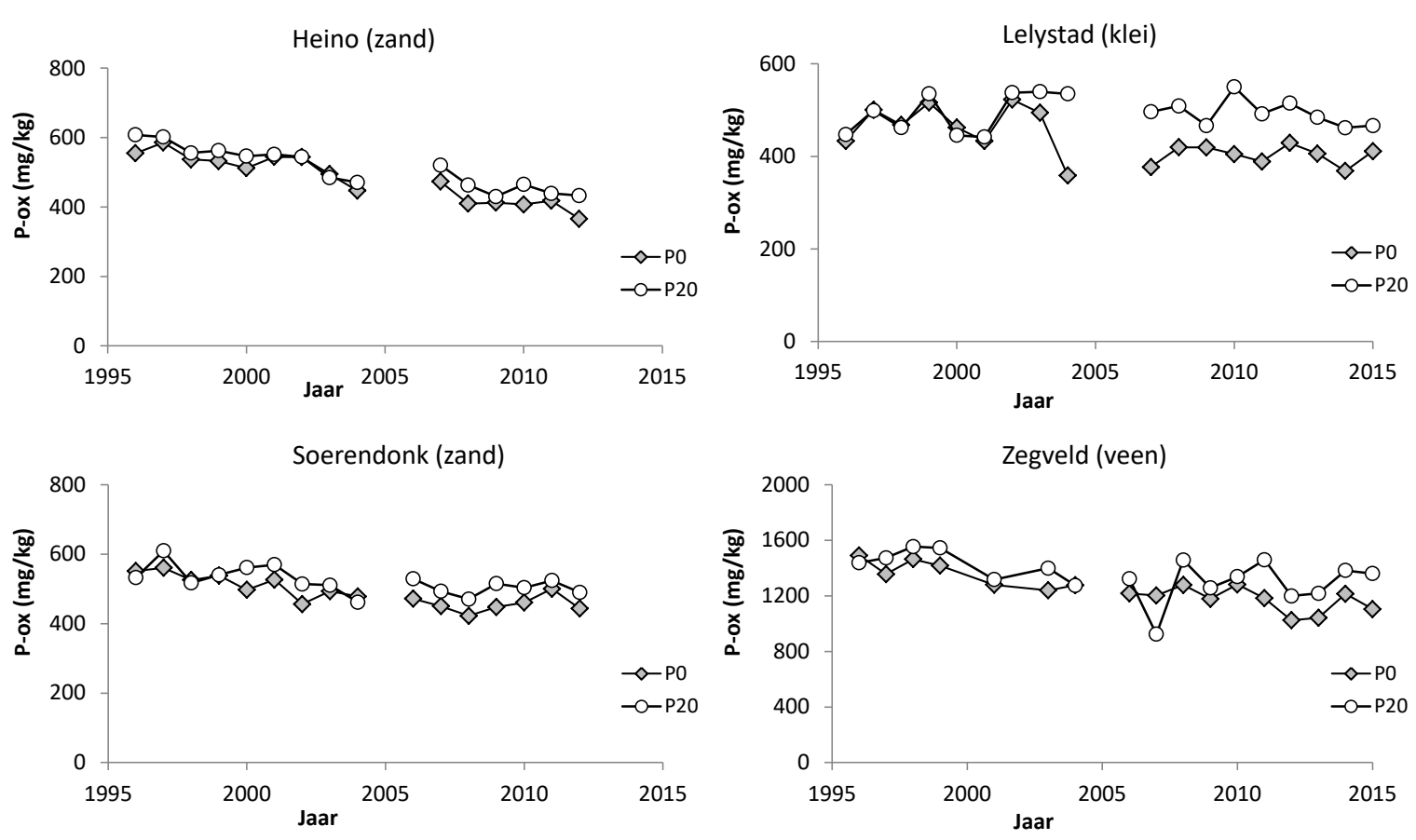

Figuur 3.15 -oxalaatgehalte in de $0-10 \mathrm{~cm}$ bodemlaag bij evenwichtsbemesting (PO) en overschotbemesting (P20) op de vier proeflocaties.

Het P-ox-gehalte kan gebruikt worden om de P-verzadigingsgraad van de minerale bodemfractie uit te drukken. De P-verzadigingsgraad wordt gebruikt in modelberekening voor het voorspellen van fosfaatuitspoeling. Bij een hoge P-verzadigingsgraad neemt de kans op fosfaatuitspoeling toe. De P-verzadingsgraad wordt berekend volgens vergelijking 2:

$P-$ verzadigingsgraad $=\frac{P_{o x}}{0.5 *\left(F e_{o x}+A l_{o x}\right)}$

Vergelijking 2 .

waarbij P-ox, Fe-ox en Al-ox zijn uitgedrukt in $\mathrm{mmol} / \mathrm{kg}$.

Bij evenwichtsbemesting wordt op alle proefvelden een daling in de P-verzadigingsgraad van 5-14\% waargenomen (Tabel 3.6).

Tabel 3.6 Fosfaatverzadigingsgraad in de $0-10 \mathrm{~cm}$ bodemlaag bij aanvang van de proef en na 15-19 jaar evenwichts- of overschotbemesting.

\begin{tabular}{lllll} 
Locatie & P-verzading (1996) & P-verzading na & $\mathbf{1 5 - 1 9}$ jaar & \\
Zand (Heino) & & P0 & P20 & P40 \\
\hline Zand (Soerendonk) & 0,54 & 0,40 & 0,45 & 0,47 \\
\hline Zeeklei (Lelystad) & 0,48 & 0,37 & 0,41 & 0,44 \\
\hline Veen (Zegveld) & 0,39 & 0,34 & 0,40 & 0,45 \\
\hline
\end{tabular}

a De P-verzadigingsgraad in de $0-10 \mathrm{~cm}$ bodemlaag berekend volgens vergelijking 1 op basis van de P-ox, Fe-ox en Al-ox gehalten in de $0-5$ en 5-10 bodemlaag. De initiële P-verzadigingsgraad is berekend als het gemiddelde over 1996 en 1997. De huidige P-verzadigingsgraad is berekend als het gemiddelde van de laatste drie meetjaren (Heino: 2010-2012; Soerendonk, 2011-2013; Lelystad en Zegveld: 2013-2015).

Op basis van de adsorptie-isothermen (Figuur 3.16) kan de relatie tussen de P-verzadigingsgraad en de $\mathrm{P}-\mathrm{CaCl}_{2}$-concentratie inzichtelijk gemaakt worden. De adsorptie-isothermen zijn per proefveld afgeleid op basis van de meetdata. Door het grote aantal datapunten ( $>200$ per locatie) is het mogelijk om, ondanks de grote temporele variatie in de $\mathrm{P}-\mathrm{CaCl}_{2}$-concentraties, adsorptie-isothermen af te leiden. Bij een hoge $\mathrm{P}$-verzadiging wordt de $\mathrm{P}-\mathrm{CaCl}_{2}$-concentratie slecht gebufferd (vlakke deel van de isotherm) en bij een lage $\mathrm{P}$-verzadiging wordt de $\mathrm{P}-\mathrm{CaCl}_{2}$-concentratie goed gebufferd (steile 
deel van de isotherm). Zodoende leidt een afname in de P-verzadiging (of P-ox) bij fosfaatverzadigde gronden tot een relatief grote afname in de $\mathrm{P}-\mathrm{CaCl}_{2}-$ concentratie. Bij gronden met een lage

$\mathrm{P}$-verzadiging heeft een verdere verlaging in $\mathrm{P}$-ox een relatief klein effect op de $\mathrm{P}-\mathrm{CaCl}_{2}$-concentratie.

De pijlen in Figuur 3.16 geven de initiële en huidige P-verzadigingsgraad en bijbehorende gemiddelde $\mathrm{P}-\mathrm{CaCl}_{2}$-concentratie aan. Op Heino en Zegveld wordt op basis van de afname in de P-verzadiging een sterke afname in $\mathrm{P}-\mathrm{CaCl}_{2}$ verwacht, wat overeenkomt met de waargenomen sterke daling in $\mathrm{P}-\mathrm{CaCl}_{2}$ gedurende de eerste jaren na aanvang van de proef. Op Lelystad en Soerendonk wordt een vergelijkbaar, maar minder sterk effect waargenomen. De proefvelden bevinden zich nu op een punt waar de $\mathrm{P}-\mathrm{CaCl}_{2}$-concentratie goed wordt gebufferd. Dit betekent dat een verdere verlaging in het $\mathrm{P}$-ox-gehalte weinig effect heeft op $\mathrm{P}-\mathrm{CaCl}_{2}$ zal hebben. Andersom betekent dit ook dat een relatief grote reparatiegift nodig is om de $\mathrm{P}-\mathrm{CaCl}_{2}$-concentratie te verhogen.

Deze resultaten kunnen vertaald worden naar de mate van fosfaatuitspoeling. De uitspoeling van ortho-P wordt bepaald door de ortho-P-concentratie in het bodemvocht die, evenals $\mathrm{P}-\mathrm{CaCl}_{2}$, in evenwicht is met de mate van P-verzadiging. Dit geldt echter niet voor de concentratie organische $P$, die grotendeels de uitspoeling vanuit grasland bepaalt.
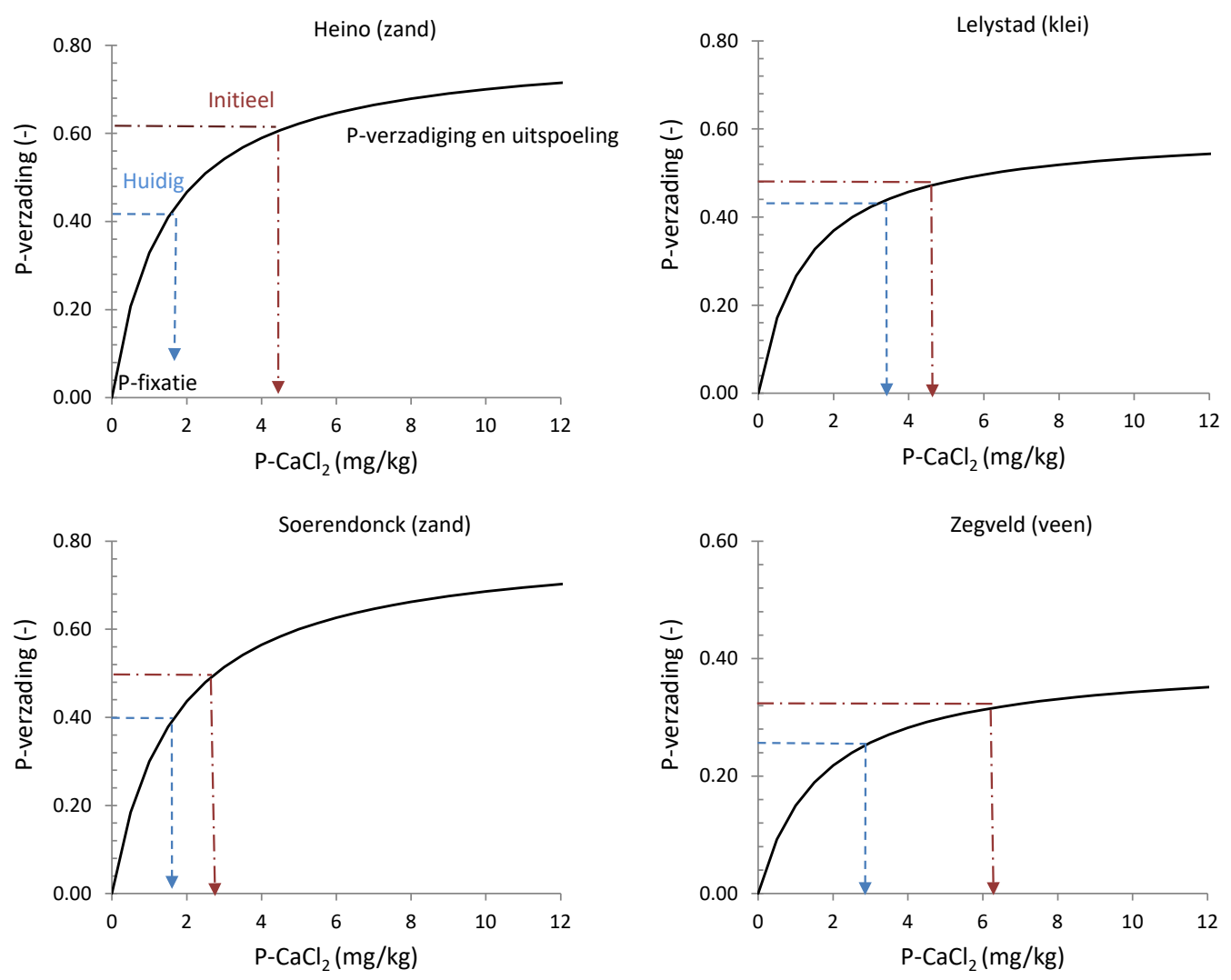

Figuur 3.16 Adsorptie-isothermen afgeleid door middel van een statistische analyse van de vier veldproeven waarin de initiële (rode lijn) en de huidige (blauwe lijn) fosfaattoestand van de $0-5 \mathrm{~cm}$ bodemlaag is aangegeven. De P-verzadiging is berekend volgens vergelijking 2.

\section{Organisch fosfaat}

Figuur 3.17 toont het verloop van het organisch P-gehalte in de bovenste $10 \mathrm{~cm}$ van de bodem bij evenwichtsbemesting en overschotbemesting. Op kleigrond neemt het organisch P-gehalte in de 0-10 cm bodemlaag toe van $192 \mathrm{mg} / \mathrm{kg}$ naar $426 \mathrm{mg} / \mathrm{kg}$ gedurende 15 jaren. Deze sterke toename in organisch fosfaat wordt gevonden bij alle fosfaatbehandelingen en is in lijn met de sterke toename in het organische-stofgehalte in de bodem (Figuur 3.20). Op de andere locaties wordt een kleine $(<10 \%$ in 15 jaar), maar statistisch significante toename in het organisch P-gehalte waargenomen

(Van der Salm et al., 2017) 

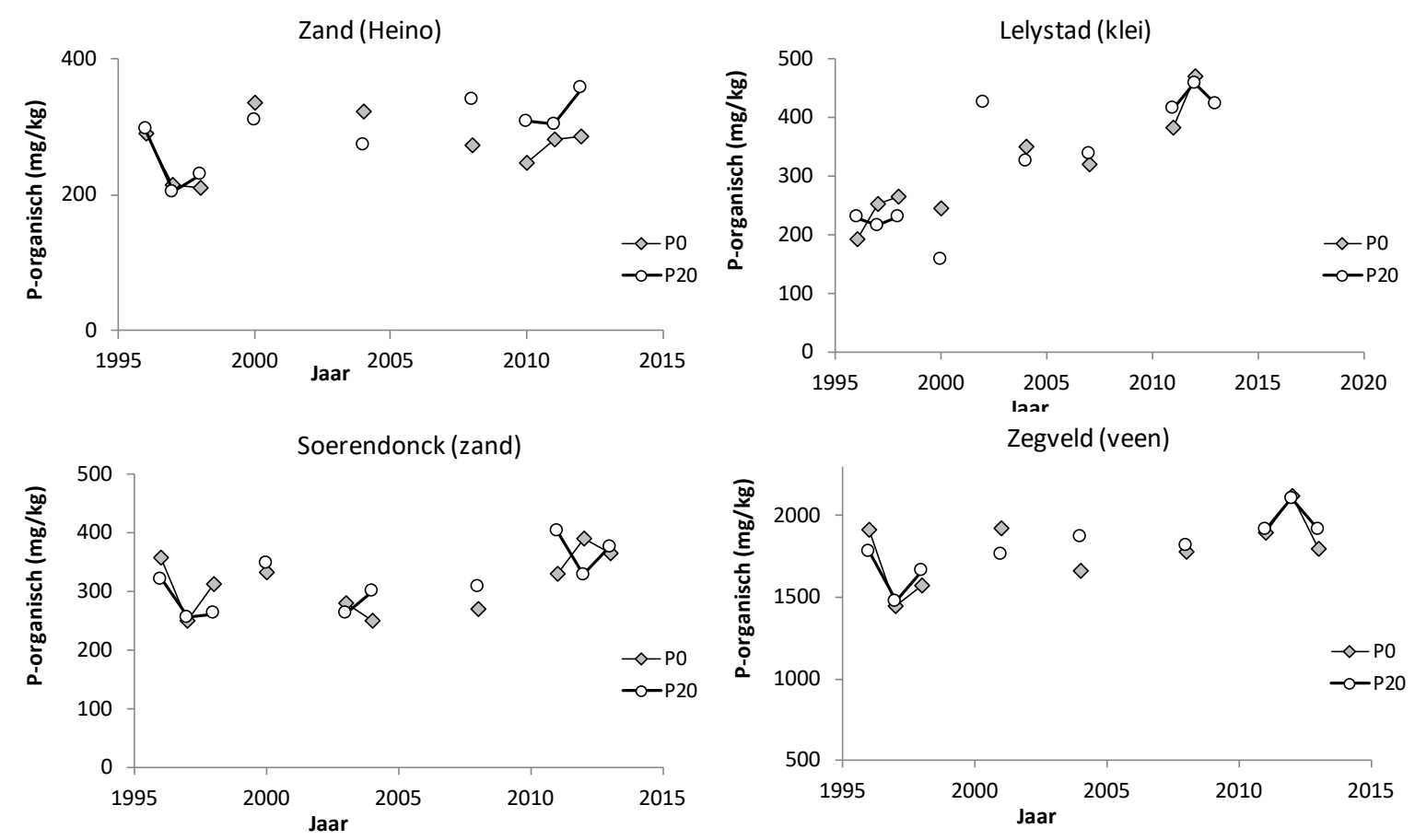

Figuur 3.17 Organisch fosfaat in $0-10 \mathrm{~cm}$ bodemlaag bij evenwichtsbemesting op de vier proeflocaties bepaald als gemiddelde in de bodemlaag 0-5 en 5-10 cm.

\subsubsection{Verdeling van fosfaat over fosfaatfracties}

De fosfaattoestand in de proefvelden is gemonitord aan de hand van diverse bodemtesten.

Figuur 3.18 toont schematisch aan welke fosfaatfractie in de bodem met de verschillende gehanteerde $\mathrm{P}$-analyses wordt bepaald. Het $\mathrm{P}-\mathrm{CaCl}_{2}$ - en Pw-getal zijn een maat voor het direct beschikbare fosfaat (P-intensiteit). Het P-Al-getal extraheert het zwak-gebonden fosfaat en P-ox extraheert daarnaast het sterk-gebonden fosfaat. Beide fosfaatfracties kunnen door desorptie beschikbaar komen waarbij het zwak-gebonden fosfaat een hogere desorptiesnelheid heeft dan sterk-gebonden fosfaat. De resterende P-fractie wordt aanduid als 'P-gefixeerd', omdat wordt aangenomen dat dit P niet of zeer beperkt beschikbaar komt voor gewasopname. Deze P-fractie bestaat uit organisch fosfaat of fosfaat-gebonden in zeer stabiele mineralen. Bij deze interpretatie moet worden opgemerkt dat er geen eenduidige relatie bestaat tussen bodemtesten en fosfaatfracties.

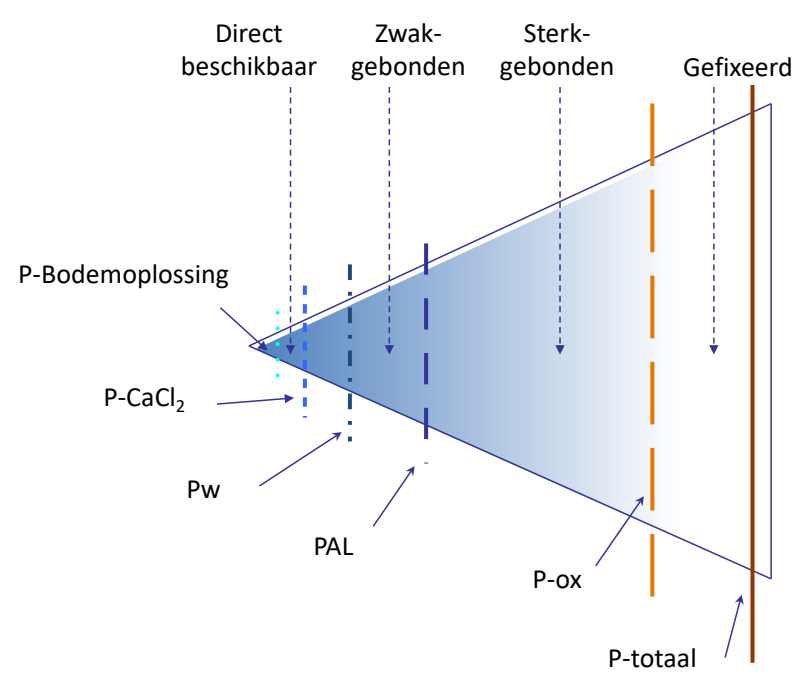

Figuur 3.18 Schematisch overzicht van fosfaatvoorraden in de bodem in relatie tot bodemtesten. 
Figuur 3.19 toont de initiële en huidige verdeling van $P$ over de verschillende $P$-fracties in de $0-5 \mathrm{~cm}$ bodemlaag bij evenwichtsbemesting. Maximaal $2 \%$ van het totale fosfaat is direct beschikbaar (P-CaCl $2, \mathrm{Pw}$-getal). In 1996 was 5-24\% van het fosfaat is zwak-gebonden, 30-60\% sterk-gebonden en $15-45 \%$ gefixeerd. Onder evenwichtsbemesting wordt op alle grondsoorten een toename in de fractie gefixeerd $\mathrm{P}$ en een afname in het (zwak en sterk) gebonden $\mathrm{P}$ waargenomen. Op de zeekleigrond wordt de toename in gefixeerd $P$ grotendeels verklaard door de toename in organisch- $P$ (Figuur 3.17). Op de andere gronden is de toename in gefixeerd fosfaat een gevolg van de combinatie van vastlegging in organisch fosfaat en stabiele mineralen (Van der Salm et al., 2017).
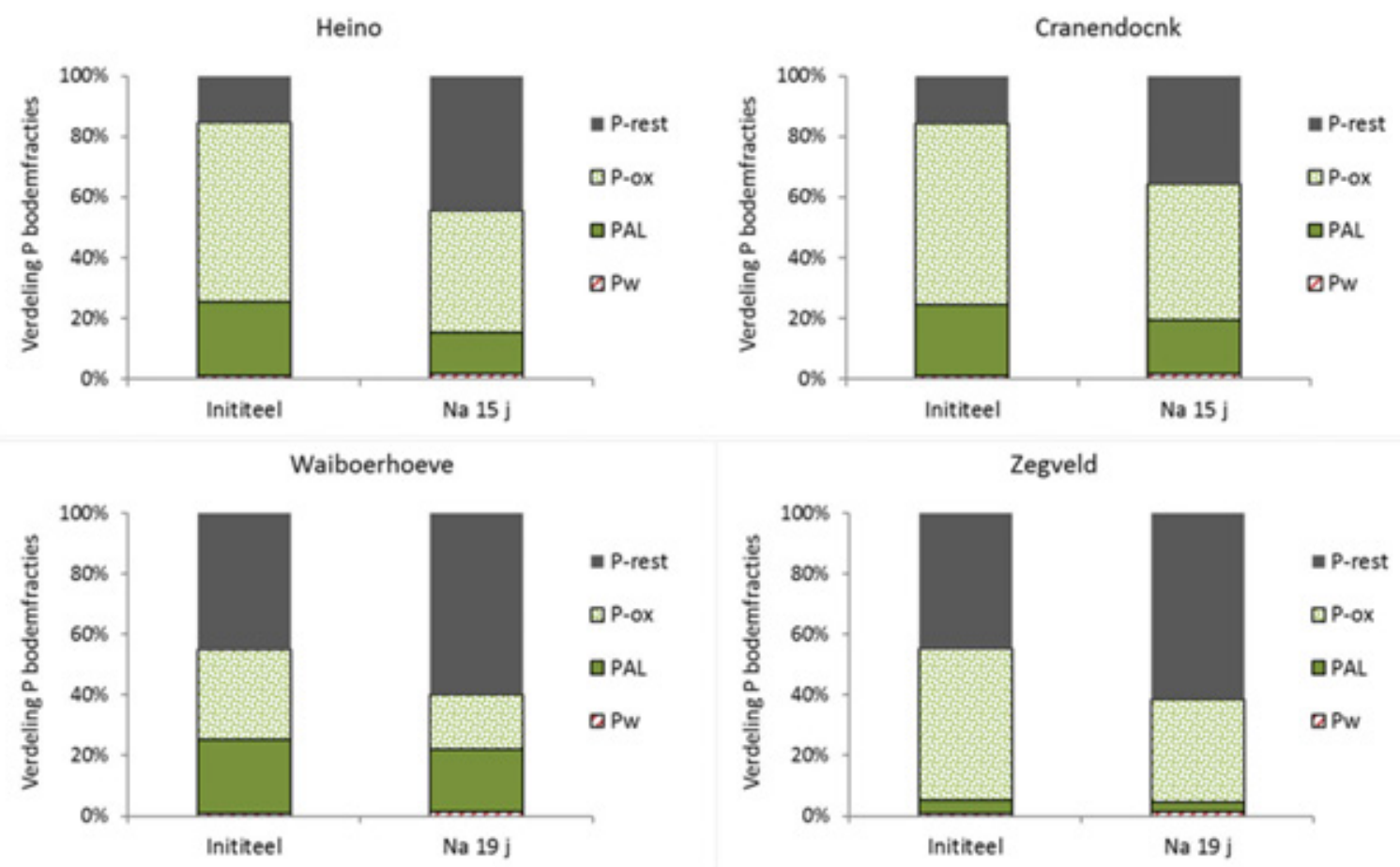

Figuur 3.19 Verdeling van de totale fosfaatvoorraad in de $0-5 \mathrm{~cm}$ bodemlaag over de fosfaatfracties $P$-CaCl,$P w$-getal, P-Al-getal, P-oxalaat en P-gefixeerd bij aanvang (1996-97) van de proef en de huidige situatie (laatste drie meetjaren). Definities van fosfaatbeschikbaarheid in relatie tot bodemtest zie Figuur 3.18.

\subsubsection{Organische stof}

Het verloop in organische-stofgehalte (gloeiverlies) in de 0-10 en 10-30 cm bodemlaag is weergegeven in Figuur 3.20. Op de zandgronden toont het organische-stofgehalte in de bovenste $10 \mathrm{~cm}$ van de bodem een lichte toename, terwijl het organische-stofgehalte in de $10-30 \mathrm{~cm}$ bodemlaag licht daalt. De veranderingen in de 0-10 en 10-20 cm bodemlaag heffen elkaar dus op. Op de kleigrond neemt de organische stof in de $0-10 \mathrm{~cm}$ bodemlaag toe van $8 \%$ tot $11 \%$, terwijl het organische-stofgehalte in de 10-30 cm daalt van 5,1 naar 4,3\%. Op kleigrond is dus sprake van een substantiële toename in het organische-stofgehalte. Op de veengrond blijft het organische-stofgehalte in beide bodemlagen constant. Er kan geconcludeerd worden dat er bij evenwichtsbemesting geen veranderingen optreden in het organische-stofgehalte in de wortelzone $(0-30 \mathrm{~cm})$. 

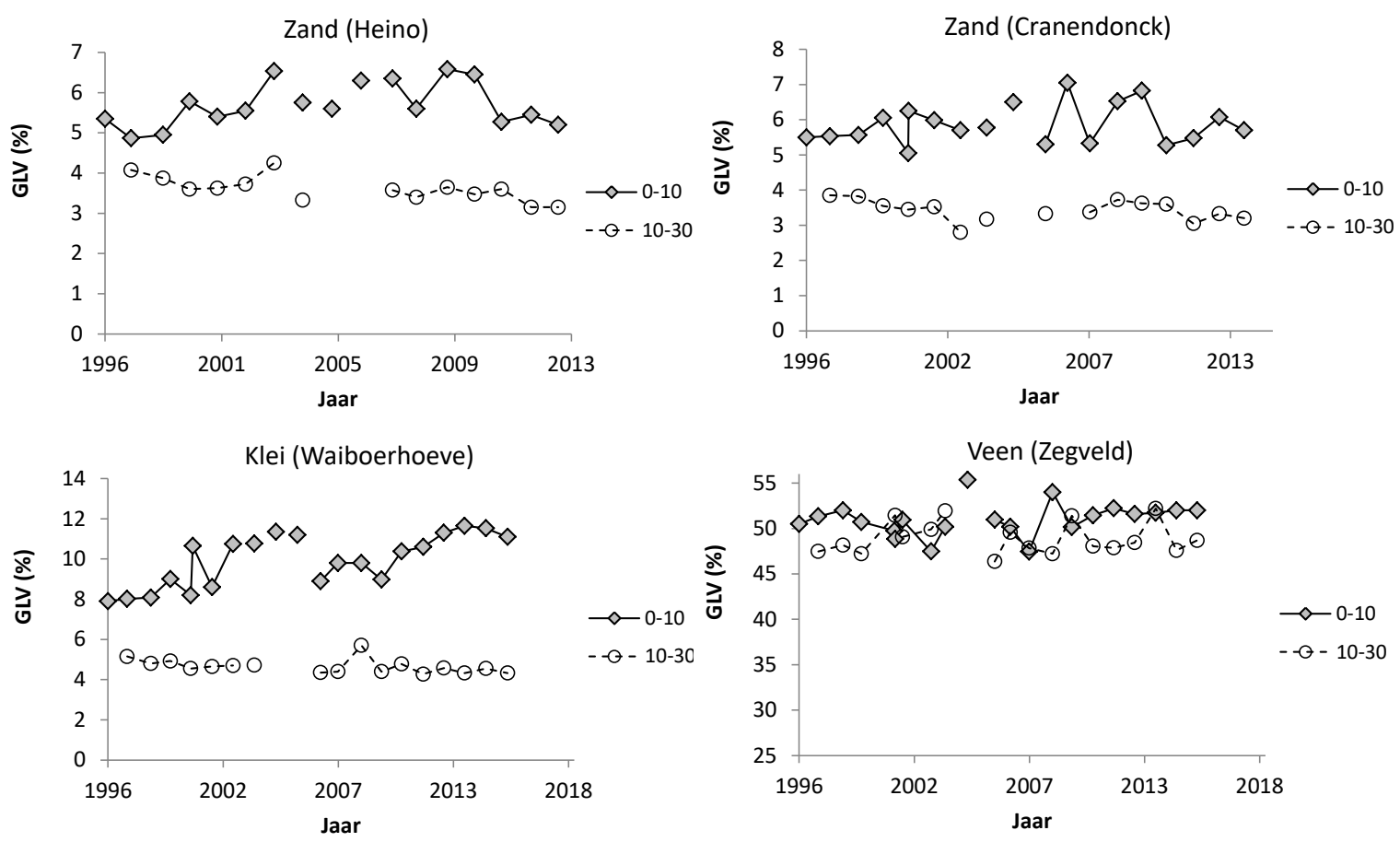

Figuur 3.20 Verloop in organische-stofgehalte (gloeiverlies) vanaf 1996 in de 0-10 en 10-30 cm bodemlaag bij evenwichtsbemesting (0-10 cm bepaald als gemiddelde $0-5$ en 5-10; $10-30 \mathrm{~cm}$ bepaald als gemiddelde 10-20 en 20-30).

\subsubsection{Uitmijnen van fosfaat (geen fosfaatbemesting)}

Op iedere proefveldlocatie is één veldje aangelegd waar sinds 2002 géén fosfaatbemesting meer wordt toegepast. Het betreft hier dus een extreme vorm van fosfaat uitmijnen. Omdat deze proef met name interessant is vanuit het oogpunt van uitspoeling en uitmijnen, zijn de profielbemonsteringen van de P-bodemtesten in deze rapportage opgenomen.

Figuur 3.21 toont de profielbemonstering van het P-Al-getal bij aanvang van de proef en in de huidige situatie (10-13 jaar na aanvang van uitmijnen). Uitmijnen van fosfaat leidt tot een sterke afname in het P-Al-getal in de bovenste $10 \mathrm{~cm}$ van de bodem. Op 20-30 cm diepte heeft uitmijnen een klein (zandgronden) of geen (klei en veengrond) effect op het P-Al-getal.

De zandgronden hebben in de initiële situatie een diep fosfaatprofiel waarbij op 20-30 cm diepte nog hoge P-AL-waarden worden aangetroffen. Bij het uitmijnen van zandgronden wordt de bovengrond sterk uitgeput waardoor op termijn de bovengrond $(0-10 \mathrm{~cm})$ een lager P-Al-getal heeft dan de ondergrond $(10-30 \mathrm{~cm})$. Door de bodem te ploegen, worden beide bodemlagen gemengd waardoor de P-opname toeneemt en de P-uitspoeling vermindert.

Op de veen- en kleigrond neemt het P-Al-getal sterk af met de diepte. Hier zou ploegen juist een negatief effect hebben op de P-uitspoeling. 

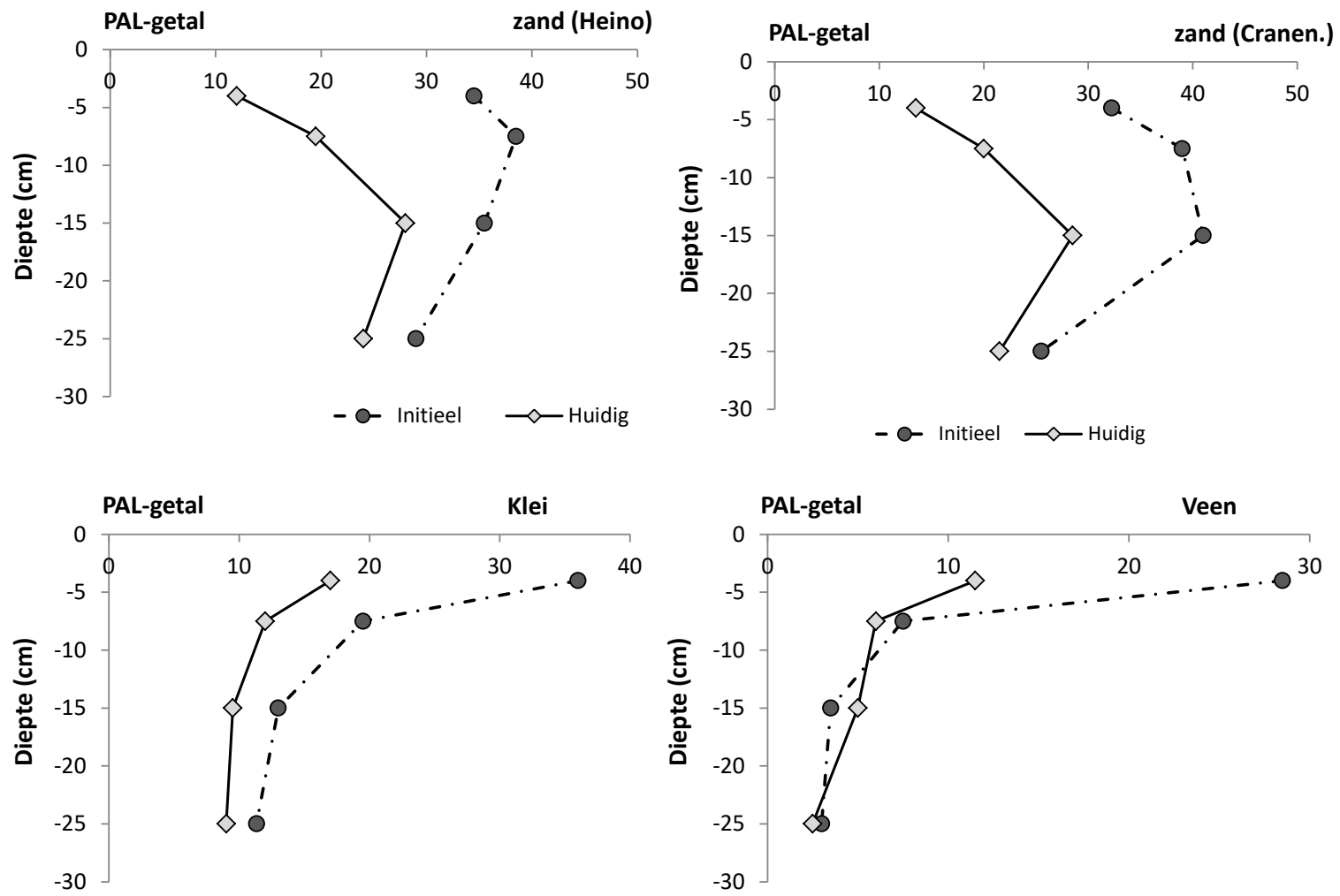

Figuur 3.21 Initieel en huidig P-Al-getal in de uitmijnveldjes (geen fosfaatbemesting) op 0-5, 5-10, 10-20 en $20-30 \mathrm{~cm}$ diepte.

\subsection{Bodemvocht}

\subsubsection{Fosfaatconcentraties in het bodemvocht bij evenwichts- en overschotbemesting}

In de periode 1997-2011 zijn de fosfaatconcentraties in het bodemvocht gemonitord waarbij zowel $\mathrm{P}$-totaal als ortho-P zijn bepaald. Het verschil tussen P-totaal en ortho-P wordt aangeduid met de term 'organisch fosfaat', al kan deze fractie op klei-houdende gronden ook bestaan uit colloïdaal fosfaat (i.e. fosfaat gebonden aan kleideeltjes etc.). In wetenschappelijke literatuur wordt deze fractie aangeduid als molybdate unreactive $P$ (MUP). Figuur 3.22 toont het verloop van de fosfaatconcentraties gedurende de periode 1997-2011 bij evenwichtsbemesting in de bodemlagen 0-5 en $20-30 \mathrm{~cm}$. Figuur 3.23 toont de gemiddelde fosfaatconcentraties in het bodemvocht bij evenwichtsbemesting, overschotbemesting en uitmijnen (geen P-bemesting). De fosfaatconcentraties zijn hiervoor gemiddeld over de periode 2004-2011, i.e. acht tot vijftien jaar na het opleggen van de fosfaatbemestingen. Voor dit tijdsbestek is gekozen, omdat er vanaf 2004 duidelijke verschillen optreden in P-Al-getal tussen de fosfaatbehandelingen (paragraaf 3.5.1). De meetresultaten van de voorafgaande periode (1997-2004) zijn reeds eerder beschreven (Van Middelkoop et al., 2007).

Op veen- en kleigrond nemen P-concentraties in het bodemvocht sterk af met toenemende diepte, terwijl P-concentraties op zandgrond zowel in de bovengrond (0-5) als onder in de wortelzone (20-30) hoog zijn. P-totaal in bodemvocht is grotendeels aanwezig in de vorm van organisch-P. De uitspoeling van $\mathrm{P}$ uit de wortelzone $(20-30 \mathrm{~cm})$ wordt voor $75-92 \%$ bepaald door uitspoeling van organisch-P en slechts voor $8-25 \%$ door uitspoeling van ortho-P.

Fosfaatconcentraties in bodemvocht vertonen een zeer sterke temporele variatie. Deze fluctuaties kunnen verklaard worden door het feit dat fosfaatconcentraties in bodemvocht sterk worden beïnvloed door weersomstandigheden. In natte perioden treedt verdunning op en is de P-opname door gewassen 
hoger, waardoor P-concentraties in het bodemvocht in de regel lager zijn in natter perioden. Op Soerendonk (Cranendonck) dalen de fosfaatconcentraties gedurende de eerste jaren na aanvang van evenwichtsbemesting. Op de andere locaties is geen trend zichtbaar.

Op de veen- en kleigrond zijn P-totaal en ortho-P-concentraties in de bovenste $10 \mathrm{~cm}$ van de bodem lager bij evenwichtsbemesting dan bij overschotbemesting. Op de zandgronden zijn deze verschillen minder duidelijk aanwezig. De uitspoeling van $\mathrm{P}$ vanuit de wortelzone wordt grotendeels bepaald door fosfaatconcentraties in het bodemvocht op 20-30 cm diepte. Op deze diepte is geen effect van $\mathrm{P}$-overschot op de P-concentraties in het bodemvocht waargenomen. Op locatie Heino is de fosfaatuitspoeling vanuit de wortelzone hoger bij evenwichtsbemesting dan bij overschotbemesting. Een verklaring hiervoor is niet gevonden.

De gemiddelde fosfaatconcentraties in bodemvocht in de periode 2004-2011 bij uitmijnen zijn opgenomen in Figuur 3.23. Op zandgrond Heino zijn fosfaatconcentraties in de gehele wortelzone (0-30 cm) lager bij uitmijnen dan bij evenwichtsbemesting. Op zandgrond Soerendonk (Cranendonck), waar fosfaatconcentraties in de wortelzone eveneens hoog zijn, heeft uitmijnen alleen een effect op fosfaatconcentraties in de bovenste 0-5 en 5-10 cm van de bodem. Ook op de veen- en kleigrond, waar fosfaatconcentraties in bodemvocht sterk afnemen met de diepte, beperken de effecten van uitmijnen zich tot de bovenste $10 \mathrm{~cm}$ van de bodem. Alleen op Heino is de uitspoeling lager bij uitmijnen dan bij evenwichtsbemesting. Op de overige drie locaties beperken de effecten van uitmijnen zich tot bovenste $10 \mathrm{~cm}$ van de bodem, terwijl de fosfaatuitspoeling aan de onderzijde van de wortelzone $(20-30 \mathrm{~cm})$ niet afneemt. 

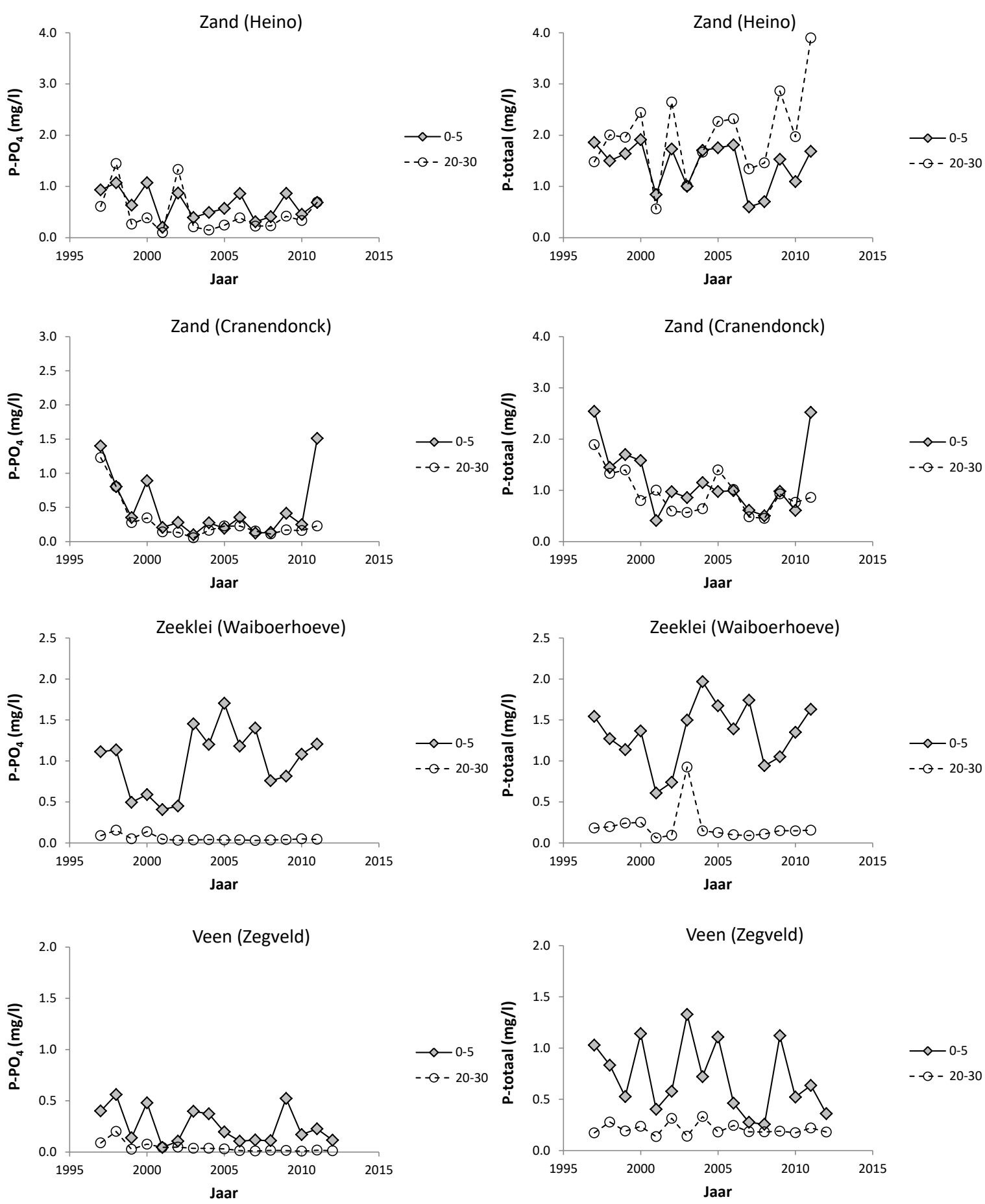

Figuur 3.22 Jaargemiddelde fosfaatconcentraties in het bodemvocht bij evenwichtsbemesting (PO) in de bodemlaag 0-5 en 20-30 cm. Links: ortho-fosfaat, rechts: totaalfosfaat. 

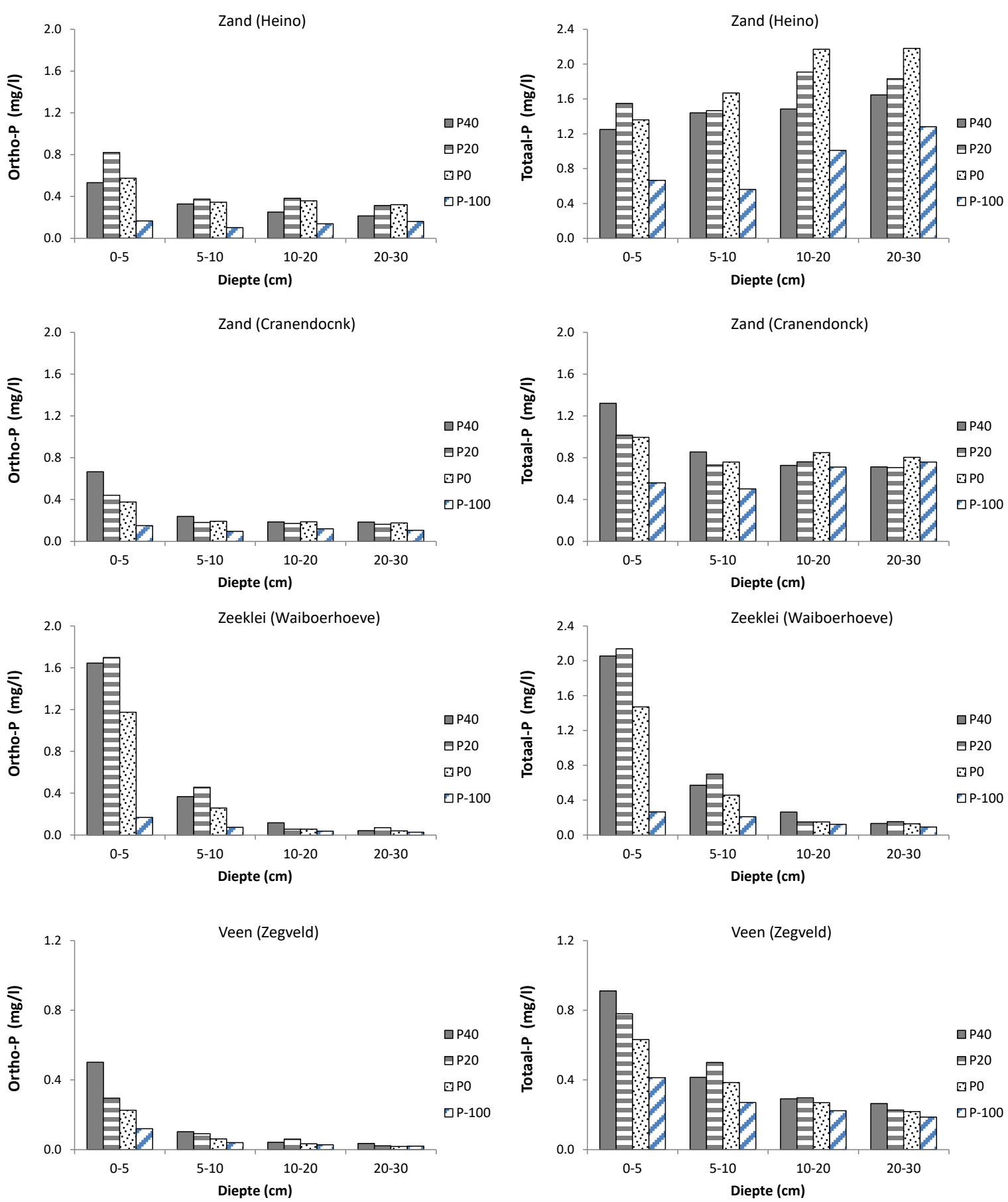

Figuur 3.23 Gemiddelde fosfaatconcentraties in het bodemvocht over de periode 2004-2011 bij evenwichtsbemesting (PO), een fosfaatoverschot van 20 en $40 \mathrm{~kg} \mathrm{P}_{2} \mathrm{O}_{2} / \mathrm{ha} / \mathrm{jaar}(\mathrm{P2O}, \mathrm{P40})$ en bij uitmijnen ( $P$-100, afvoer van fosfaat van aanvankelijk $100 \mathrm{~kg} P_{2} \mathrm{O}_{5} /$ ha later dalend (zie tekst)). Links: ortho-fosfaat, rechts: totaalfosfaat.

\subsubsection{Uitspoelingsverliezen bij evenwichts- en overschotbemesting}

De fosfaatverliezen uit de wortelzone $(0-30 \mathrm{~cm})$ kunnen berekend worden aan de hand van de fosfaatconcentraties in het bodemvocht en de hydrologische fluxen vanuit de wortelzone. De hydrologische fluxen vanuit de wortelzone zijn berekend met het hydrologische model SWAP. Hiermee worden zowel de neerwaartse als laterale fluxen bepaald. De hier getoonde uitspoelingsverliezen, welke zijn berekend voor de periode 1997-2004, zijn overgenomen vanuit Van Middelkoop et al. (2007). 
De jaargemiddelde fosfaatverliezen zijn aanzienlijk hoger op zandgrond dan op zeeklei en veengrond. Jaargemiddelde fosfaatverliezen door uitspoeling variëren van $1,0 \mathrm{~kg} \mathrm{P}_{2} \mathrm{O}_{5} \mathrm{ha}^{-1} \mathrm{j}^{-1}$ op Waiboerhoeve tot $11,4 \mathrm{~kg} \mathrm{P}_{2} \mathrm{O}_{5} \mathrm{ha}^{-1} \mathrm{j}^{-1}$ op Aver Heino. De fosfaatverliezen worden bepaald door de fosfaatconcentratie in de wortelzone, de hydrologische situatie en het neerslagoverschot. De hoogste uitspoelingsverliezen komen voor op Heino, waar de concentraties onder in de wortelzone het hoogst zijn (1,6 mg/L, Figuur 3.22). Relatief hoge uitspoelingsverliezen worden ook gevonden in percelen met een hoge laterale drainage. Op Zegveld bijvoorbeeld is de concentratie onder in de wortelzone relatief laag $(0,3 \mathrm{mg} / \mathrm{L}$, Figuur 3.23), maar is de uitspoeling vergelijkbaar met die op Soerendonk (Cranendonck). Het neerslagoverschot heeft eveneens een grote invloed op de hoeveelheid fosfaat die uitspoelt. In droge jaren $(1997,2003)$ is de uitspoeling op alle locaties gering en in sommige gevallen zelfs negatief. In natte jaren $(1998,2000,2002)$ is de mate van fosfaatuitspoeling aanzienlijk hoger (Van Middelkoop et al., 2007).

Op Zegveld is het fosfaatverlies lager bij evenwichtsbemesting dan bij overschotbemesting. Dit is te verklaren door de hoge bijdrage van laterale uitspoeling vanuit de bovenste $10 \mathrm{~cm}$ van de bodem en het feit dat de P-bemesting een effect heeft op de P-concentraties in de bovengrond. Op de zand-en kleigronden zijn er geen verschillen in fosfaatverliezen tussen percelen met evenwichts- en overschotbemesting. Op deze gronden, met diepere grondwaterstanden, wordt de uitspoeling vrijwel volledig bepaald door neerwaartse fluxen vanuit de wortelzone (20-30). Op deze diepte zijn er geen effecten van fosfaatbemesting op fosfaatconcentraties in het bodemvocht meetbaar (Figuur 3.23), waardoor ook de berekende fosfaatuitspoeling voor de diverse behandelingen gelijk is.

De getoonde uitspoelingsverliezen zijn berekend voor de periode tot en met 2004, maar kunnen gebruikt worden om uitspraken te doen over tot 2011 (laatste metingen in bodemvocht). De absolute uitspoelingsverliezen variëren van jaar tot jaar door de afhankelijkheid van o.a. het

neerslagoverschot. Zodoende kunnen de absolute fosfaatverliezen in de periode tot 2011 verschillen van de periode tot 2004. Echter, de verschillen in uitspoelingsverliezen tussen de verschillenden P-behandelingen zijn louter het gevolg van verschillen in P-concentraties in het bodemvocht. Omdat ook in de periode 2004-2011 geen effecten van bemesting op de P-concentraties in bodemvocht op 20-30 cm diepte zijn waargenomen, kan geconcludeerd worden dat er ook over deze laatste periode geen verschillen optreden in fosfaatverliezen bij evenwichts- en overschotbemesting.

Er kan geconcludeerd worden dat fosfaatverliezen vanuit de wortelzone over de beschouwde periode gelijk zijn bij evenwichts- en overschotbemesting, met uitzondering van veengronden met een hoge laterale uitspoeling waar de fosfaatuitspoeling lager is bij evenwichtsbemesting. Of op termijn verschillen gaan ontstaan, is nog niet aan te geven. 

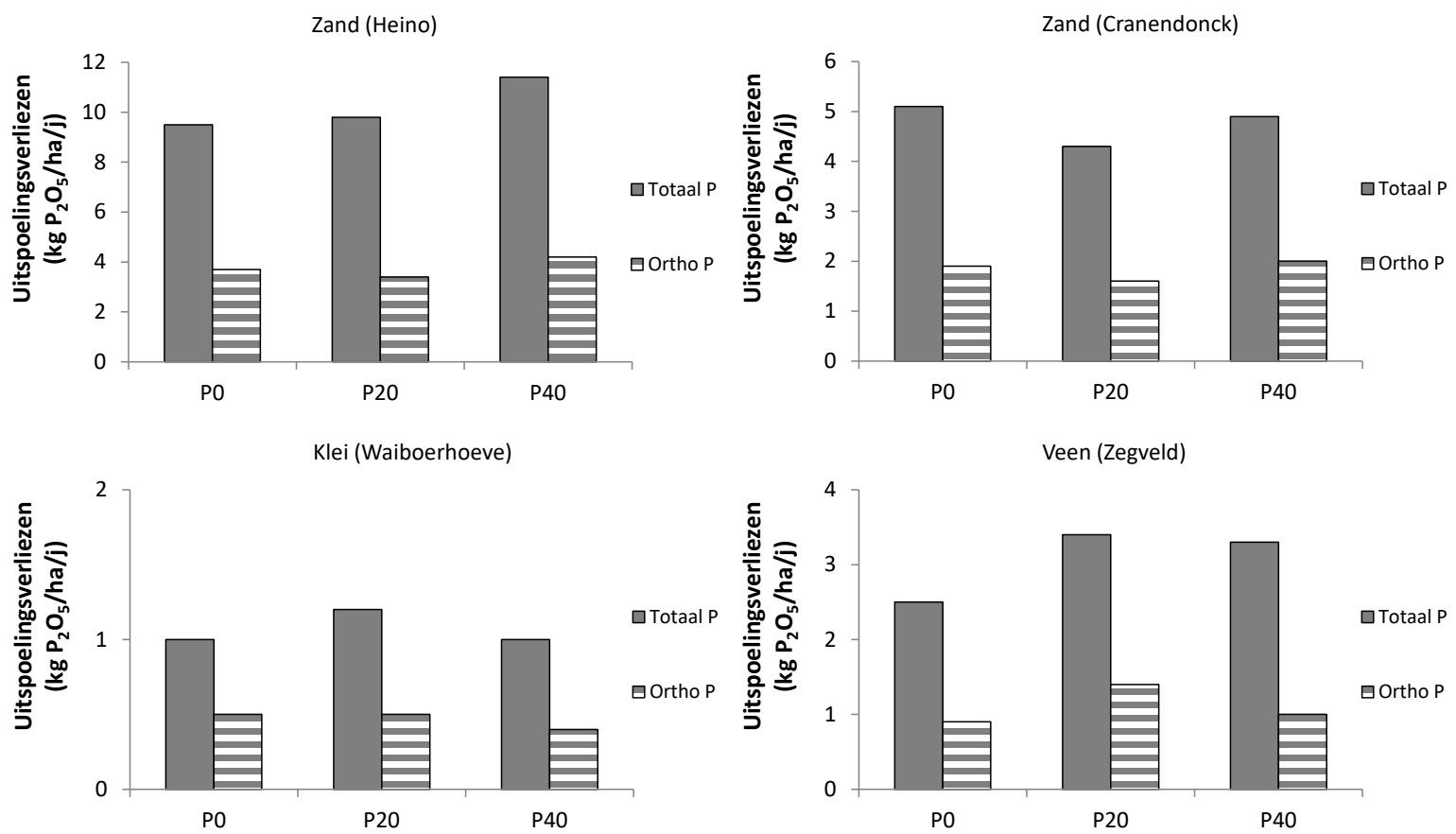

Figuur 3.24 Fosfaatverliezen ten gevolge van uitspoeling uit de wortelzone $(0-30 \mathrm{~cm})$ op basis van berekende hydrologische fluxen en P-concentraties in het bodemvocht in de periode 1997-2004 bij evenwichtsbemesting (PO) en een overschot van 20 of $40 \mathrm{~kg} \mathrm{P}_{2} \mathrm{O}_{5} / \mathrm{ha} / \mathrm{jaar}(\mathrm{P20}, \mathrm{P40})$. Data overgenomen uit Van Middelkoop et al., 2007.

\subsection{Landbouwkundig en bodemkundig perspectief}

\subsubsection{Landbouwkundig perspectief}

De doorwerking van resultaten uit de proef in verschillende bedrijfssystemen is geen onderdeel van de proef, maar is wel relevant voor praktijk. Enkele aspecten zullen hier genoemd worden.

\section{$P$-gehalte in gras en rantsoen}

$\mathrm{P}$ in het gras maakt een belangrijk deel uit van de P-opname van het melkvee. De dieren hebben voldoende $\mathrm{P}$ nodig om melk te produceren en gezond te blijven. Op dit moment is echter ook een belangrijke tendens in de melkveehouderij om het P-gehalte van gras zo laag mogelijk te krijgen in verband met de bedrijfsspecifiek excretie (BEX) van P in de mest (Krimpen et al., 2010). Tegelijkertijd spannen krachtvoerproducenten zich in om het P-gehalte in de aangekochte krachtvoeders te verlagen, zoals afgesproken in een convenant met de overheid. Ten slotte is het fosfaatreductieplan van belang om onder het fosfaatplafond te komen.

De voedernormen voor de P-opname van melkvee zijn vastgesteld en gepubliceerd door het Centraal Veevoeder Bureau (CVB). De normen zijn echter op rantsoenniveau opgesteld. Het hangt dus van de rest van het rantsoen van melkvee af hoe hoog (of laag) het P-gehalte van het gras minimaal dient te zijn voor de gezondheid van het vee.

Met deze normen en gehalten zijn in een ander project (Van Middelkoop et al., 2014) schattingen gemaakt van de minimale benodigde gehalten in graskuilen. Tabel 3.7 is uit dit project overgenomen. Bij de berekeningen voor deze tabel is gebruikgemaakt van de rantsoenberekening uit het Bedrijfsbegrotingsprogramma Rundvee (BBPR) zoals dat door Wageningen Livestock Research wordt gebruikt om volledige melkveebedrijven te simuleren. Vergeleken zijn verschillende rantsoenen, uitgedrukt in het aandeel snijmais in het ruwvoer, voor melkkoeien in het begin van de lactatie (40 kg melk per dag) en aan het eind van de lactatie (20 kg melk per dag). De P-gehalten in krachtvoer zijn de gehalten die door de Werkgroep Uniformering Mestuitscheiding (WUM) voor 2011 waren vastgesteld als gemiddelde voor krachtvoer zoals dat in Nederland werd gebruikt in dat jaar. 
Het resultaat is dat bij de laagproductieve melkkoeien (20 kg melk per dag) het P-gehalte in het gras niet hoger dan $2 \mathrm{~g}$ per $\mathrm{kg}$ ds hoeft te zijn. Bij hoogproductieve melkkoeien en een groot aandeel snijmais in het rantsoen ( $50 \%$ ) is het benodigde P-gehalte 3,6 g P per $\mathrm{kg}$ ds. Door conservering en drogestofverlies tijdens conservering is het gehalte in graskuil ca. 0,3 g P per $\mathrm{kg}$ ds hoger dan in vers gras. Voor graskuil zou daarom een gehalte van 3,3 g P per kg ds in het verse gras voldoende zijn. Wanneer deze uitkomsten vergeleken worden met de uitkomsten van de plots met evenwichtsbemesting, is er gemiddeld genomen net voldoende P in het gras aanwezig om zowel bij beweiding als stalvoedering op de voedernorm te kunnen voeren. Op basis van de variatie in Figuur 3.4 is echter op te merken dat er ook jaren zullen zijn dat het melkvee niet voldoende $P$ opneemt bij evenwichtsbemesting. Bij een gematigder aandeel snijmaïs in het rantsoen (32\%) is er gemiddeld gesproken nog geen gevaar voor een te lage P-opname, maar er zijn jaren dat de melkveehouder alert zal moeten zijn.

Tabel 3.7 Opname, standaard P-gehalte (krachtvoer en snijmaïs) en benodigd gehalte in gras(kuil) voor melkkoeien van 20 en 40 liter melk/dag, P-gehalte in krachtvoer op niveau van 2011 (Van Middelkoop et al., 2014).

\begin{tabular}{|c|c|c|c|c|c|c|c|c|c|}
\hline Rantsoen & $\begin{array}{l}\text { Melk } \\
\text { per koe }\end{array}$ & P-norm & $\begin{array}{l}\text { Ds opna- } \\
\text { me } \\
\text { totaal }\end{array}$ & $\begin{array}{l}\text { opname } \\
\text { krachtvoer }\end{array}$ & $\begin{array}{l}\text { P-gehalte } \\
\text { kracht- } \\
\text { voer }\end{array}$ & $\begin{array}{l}\text { Ds- } \\
\text { opname } \\
\text { snijmaïs }\end{array}$ & $\begin{array}{l}\text { P-gehalte } \\
\text { snijmais }\end{array}$ & $\begin{array}{l}\text { Ds- } \\
\text { opname } \\
\text { gras- } \\
\text { (kuil) }\end{array}$ & $\begin{array}{l}\text { Beno- } \\
\text { digd } \\
\text { gehalte } \\
\text { gras(- } \\
\text { kuil) } \\
\end{array}$ \\
\hline $\begin{array}{l}\% \\
\text { snijmais } \\
\text { van droge } \\
\text { stof } \\
\text { ruwvoer }\end{array}$ & I/dag & g P/dag & $\begin{array}{l}\text { kg } \\
\text { ds/dag }\end{array}$ & $\begin{array}{l}\text { kg product } \\
\text { (kg } \\
\text { ds)/dag }\end{array}$ & $\begin{array}{l}\text { g P/kg } \\
\text { product }\end{array}$ & $\begin{array}{l}\text { kg } \\
\text { ds/dag }\end{array}$ & g P/kg ds & $\begin{array}{l}\text { kg } \\
\text { ds/dag }\end{array}$ & g P/kg ds \\
\hline $0 \%$ & 40 & 79 & 23,5 & $8,5(8,0)$ & 4,6 & 0 & 2 & 15,5 & 2,7 \\
\hline $32 \%$ & 40 & 79 & 23,5 & $8,5(8,0)$ & 4,6 & 5 & 2 & 10,5 & 3,1 \\
\hline $32 \%$ & 20 & 47 & 18,5 & $4,3(4,0)$ & 4,6 & 5 & 2 & 9,5 & 2,0 \\
\hline $50 \%$ & 20 & 47 & 18,5 & $4,3(4,0)$ & 4,6 & 7,75 & 2 & 6,75 & 1,9 \\
\hline $68 \%$ & 20 & 47 & 18,5 & $4,3(4,0)$ & 5,0 & 10,5 & 2 & 4 & 1,5 \\
\hline
\end{tabular}

Sinds 2011 is het P-gehalte van het krachtvoer verder verlaagd. Volgens de uitscheidingsberekeningen van 2015 door WUM is het P-gehalte van krachtvoer verlaagd naar 4,1 g per kg product in het standaard krachtvoer. Het eiwitrijke krachtvoer is nog op een vergelijkbaar niveau, 5,1 g per kg product. Dit is doorgerekend in Tabel 3.8. Dan blijkt dat het P-gehalte in gras bij een aandeel snijmaïs van $50 \% 4,0 \mathrm{~g}$ per $\mathrm{kg}$ ds in de graskuil zou moeten zijn, dus 3,7 in vers gras. Dit wordt bij evenwichtsbemesting alleen op de locatie Lelystad gemiddeld behaald.

Bij de gehalten in krachtvoer van 2015 is er bij een gematigder aandeel snijmaïs in het rantsoen (32\%) er gemiddeld gesproken nog net geen risico voor een te lage P-opname, maar ook in deze situatie zijn er jaren dat de melkveehouder alert zal moeten zijn. Wanneer het P-gehalte van het krachtvoer na 2015 verder daalt, zal het risico dat het melkvee te weinig P binnen krijgt groter worden. 
Tabel 3.8 Opname, standaard P-gehalte (krachtvoer en snijmaïs) en benodigd gehalte in gras(kuil) voor melkkoeien van 20 en 40 liter melk/dag, P-gehalte in krachtvoer op niveau van 2015 (gebaseerd op Van Middelkoop et al., 2014).

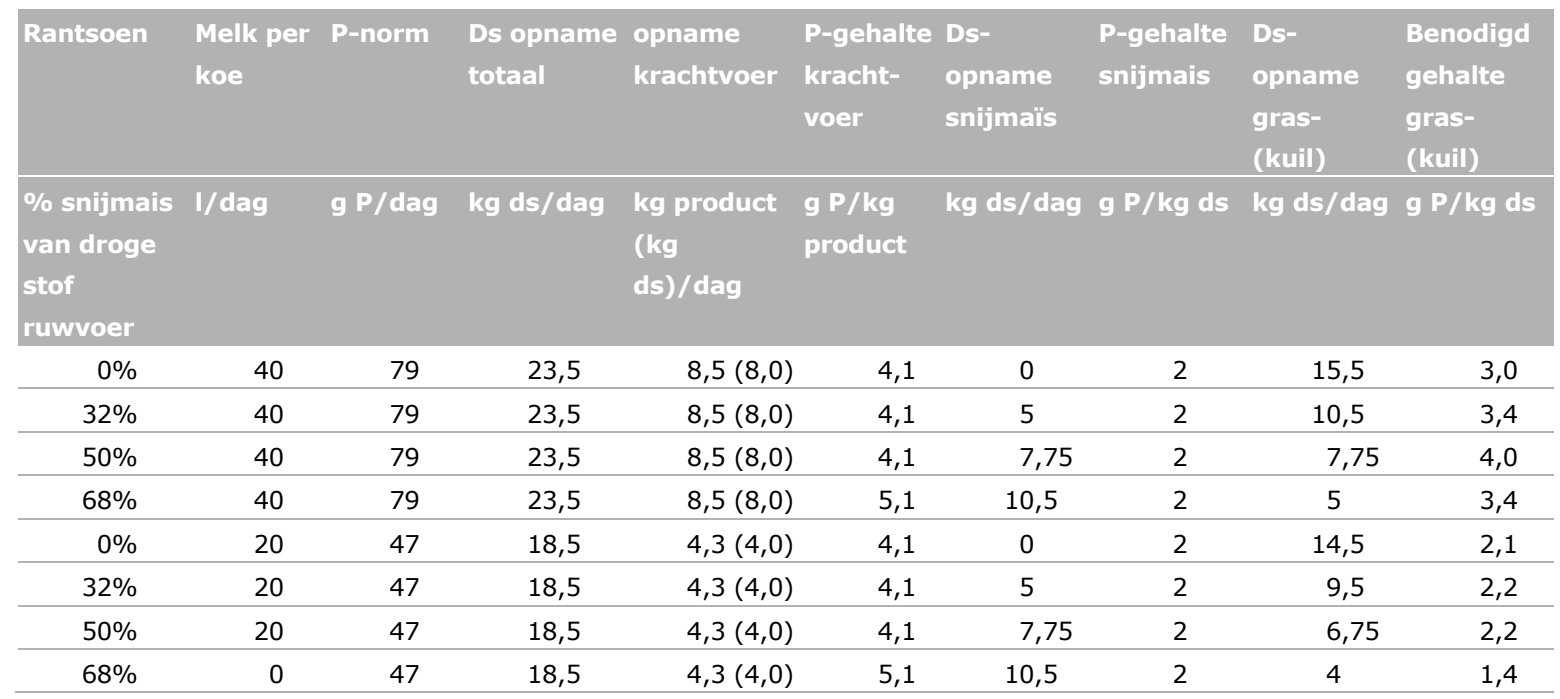

Consequenties van beweiding en beweidingsintensiteit op perceel- en bedrijfsniveau

Beweiding heeft invloed op de mineralenkringloop in het grasland. In feite worden bij beweiding door het vee fosfaat en overige mineralen van een grotere oppervlakte verzameld en op een kleine oppervlakte gedeponeerd in de vorm van een mestflat (urine bevat vrijwel geen fosfaat). Door deze ongelijke verdeling heeft beweid grasland ruimtelijk gezien verschillende overschotten. Als op een volledig perceel evenwichtsbemesting wordt toegepast, ontstaat op de plaatsen waar mestflatten liggen een positief overschot en waar geen mestflatten liggen een negatief overschot.

Fosfaat kan uit mestflatten minder goed benut worden dan uit goed verspreide mest. Ook mag verwacht worden dat vanuit mestflatten meer organisch $P$ oppervlakkig zal afspoelen dan wanneer $P$ egaal verspreid wordt. Vooral wanneer dieren tot aan de slootkant mogen grazen, is het mogelijk dat mestflatten tot dicht aan de waterkant gedeponeerd worden en afspoeling van o.a. fosfaat veroorzaken. De hoeveelheid $\mathrm{P}$ die afspoelt, is echter niet kwantificeerbaar vanuit de grasproef.

In het jaar 2000 is op een plot op locatie Heino (zand) de ruimtelijke verdeling van mestflatten vastgelegd (Van Middelkoop et al. 2004). Uit bodemanalyses bleek dat circa 1/3 van het fosfaat in de onderzochte mestflatten direct na de winter terug te vinden was in het P-totaal in de bodem in de laag 0-15 cm. Op basis van een schatting van de gewasopname in en rondom de mestflatten is geschat dat ruim de helft van de $\mathrm{P}$ uit mestflatten niet werd teruggevonden in bodem of gewas. Onder de mestflatten werd een sterk verhoogd P-Al-getal gevonden ten opzichte van onbedekte plekken.

In Van Middelkoop et al. (2016) is een schatting gemaakt van de cumulatieve overschotten die na verschillende periodes op het grasland ontstaan (Tabel 3.9). Na 15 jaar is ongeveer 60\% van het grasland onbedekt met mestflatten en het deel niet bedekt met mestflatten heeft naar schatting een negatieve fosforbalans van $255 \mathrm{~kg} P$ per ha. Ongeveer $30 \%$ is bedekt met één mestflat en heeft een positieve balans van $221 \mathrm{~kg} P$ per ha, en $10 \%$ is bedekt met twee of meer mestflatten en heeft een positieve balans van $697 \mathrm{~kg} P$ per ha of hoger. Dit was bij een beweidingsintensiteit waarbij ongeveer $50 \%$ van de geproduceerde droge stof tijdens begrazing werd opgenomen.

Hoe hoger de beweidingsintensiteit, uitgedrukt in het aantal dierdagen, hoe dichter de verdeling van mestflatten en hoe sneller het hele perceel bedekt zal zijn met minimaal 1 mestflat. In dat opzicht lijkt een hogere beweidingsintensiteit gunstiger voor de fosfaatkringloop. Hier staat tegenover dat bij minder beweiding meer dunne mest wordt verzameld. Het gestelde geldt als dunne mest wordt afgevoerd naar bijvoorbeeld snijmaïs. Het aantal dierdagen dat op een perceel gerealiseerd kan worden, is echter afhankelijk van de drogestofopbrengst, omdat de dieren gras op moeten kunnen nemen. Echter, hoe hoger de beweidingsintensiteit, hoe lager de drogestofopbrengst op een perceel (Schröder et al., 2004) en hoe lager de opname van P door het gewas op dat perceel. Op bedrijfsniveau zal de veestapel een totaalaantal dierdagen willen beweiden. Het is niet direct te beredeneren welke beweiding nu gunstiger zou zijn voor de verdeling en benutting van fosfaat: intensief op een kleiner oppervlakte met lagere opbrengsten of extensiever op een groter oppervlakte met hogere opbrengsten. 
Het zal echter altijd ongunstig zijn als de beweidingsintensiteit (te) hoog is: de veestapel neemt weinig droge stof op, maar scheidt wel $P$ uit die afkomstig is van het voer dat op stal gegeven is. Het P-overschot op dergelijke percelen zou hoog worden en het risico van afspoeling groot. Dit zou een effect kunnen zijn wanneer beweiding verplicht wordt op bedrijven die te weinig grasland hebben dat geschikt is voor beweiding, bijvoorbeeld bij een kleine huiskavel.

Tabel 3.9 Geschatte oppervlakte (in procent) van de plots onbedekt, bedekt met één en bedekt met twee of meer mestflatten, berekend met de Poissonverdeling en de geschatte cumulatieve fosforoverschotten bij afwezigheid van toediening van drijfmest (zie tekst) (Van Middelkoop et al., 2016).

\begin{tabular}{|c|c|c|c|c|c|c|}
\hline \multirow[b]{2}{*}{$\begin{array}{l}\text { Aantal } \\
\text { jaren } \\
\text { begraasd }\end{array}$} & \multicolumn{2}{|l|}{ Onbedekt } & \multicolumn{2}{|c|}{ Bedekt met 1 mestflat } & \multicolumn{2}{|c|}{ Bedekt met $\geq 2$ mestflatten } \\
\hline & $\%$ & $\begin{array}{l}\text { Geschat } \\
\text { overschot, } \\
\text { kg } \mathrm{P}_{2} \mathrm{O}_{5} \mathrm{ha}^{-1}\end{array}$ & $\%$ & $\begin{array}{l}\text { Geschat } \\
\text { overschot, } \\
\text { kg } \mathrm{P}_{2} \mathrm{O}_{5} \mathrm{ha}^{-1}\end{array}$ & $\%$ & $\begin{array}{l}\text { Geschat } \\
\text { overschot, } \\
\text { kg } \mathrm{P}_{2} \mathrm{O}_{5} \mathrm{ha}^{-1}\end{array}$ \\
\hline 1 & 96 & -39 & 4 & +1051 & 0 & $\geq 2141$ \\
\hline 10 & 70 & -389 & 25 & +701 & 5 & $\geq 1791$ \\
\hline 30 & 34 & -1168 & 37 & -78 & 29 & $\geq 1012$ \\
\hline 40 & 24 & -1557 & 34 & -467 & 42 & $\geq 623$ \\
\hline 50 & 17 & -1947 & 30 & -856 & 53 & $\geq 234$ \\
\hline
\end{tabular}

Conclusie: er zijn sterke aanwijzingen dat de benutting van P bij beweiding in mest, die tijdens beweiding op grasland terechtkomt, laag is door de heterogene ruimtelijke verdeling (Van Middelkoop et al., 2016). Mogelijk is daarom het effect van P-evenwichtsbemesting ten opzichte van bemesten volgens een P-overschot, waarbij zowel opname als uitscheiding tijdens beweiding meetellen, groter op bedrijven met beweiding en eveneens groter naarmate er tijdens het groeiseizoen meer dagen, meer uren per dag of met meer dieren wordt beweid. Intensievere beweiding leidt waarschijnlijk tot een nog lagere P-benutting en een groter risico voor afspoeling.

Verlaging van de $\mathrm{N}$-gebruiksnorm in dierlijke mest

Een (verdere) verlaging van de $\mathrm{N}$-gebruiksnorm van dierlijke mest betekent dat er of meer mest moet worden afgevoerd op een bedrijf, of eiwitarmer gevoerd moet worden, of minder dieren gehouden kunnen worden. Op dit moment is de $\mathrm{N} / \mathrm{P}_{2} \mathrm{O}_{5}$-verhouding in rundveedrijfmest 4/1,5 = 2,7.

In de gebruiksnormen is die op grasland $230 / 95^{12}=2,4$ of $250 / 95=2,6$.

De $\mathrm{N} / \mathrm{P}_{2} \mathrm{O}_{5}$-verhouding in de rundveemest is dus hoger dan in de gebruiksnormen.

Wanneer voor een bedrijf de $\mathrm{N}$-gebruiksnorm dierlijke mest naar beneden zou gaan, betekent dat er met de af te voeren $\mathrm{N}$ ook $\mathrm{P}_{2} \mathrm{O}_{5}$ moet worden afgevoerd.

Dit zou tot drie mogelijkheden kunnen leiden:

- Melkveehouders gaan op grasland onder evenwichtsbemesting bemesten.

- Om toch voldoende $\mathrm{P}_{2} \mathrm{O}_{5}$ vast te houden in de eigen dierlijke mest (kunstmest $\mathrm{P}_{2} \mathrm{O}_{5}$ aanvoeren mag niet onder derogatie), is het mogelijk dat melkveehouders weer P-rijker krachtvoer aan gaan voeren. $\mathrm{Zij}$ streven dan naar een lagere $\mathrm{N} / \mathrm{P}_{2} \mathrm{O}_{5}$-verhouding. Dit zou het voerspoor kunnen frustreren.

- Melkveehouders gaan mest scheiden en de N-rijke dunne fractie (of mineralenconcentraten) afvoeren.

Conclusie: verlaging van de $\mathrm{N}$-gebruiksnorm van dierlijke mest kan leiden tot meer P-bemesting onder evenwichtsbemesting en risico voor daling van het $\mathrm{P}$-Al-getal, verhoging van aanvoer in $\mathrm{P}$ in krachtvoer (frustrering van verlaging via voerspoor) of kan een stimulans zijn om mest te gaan scheiden.

\footnotetext{
${ }^{12} \mathrm{Hier}$ is $95 \mathrm{~kg} \mathrm{P} \mathrm{O}_{5} / \mathrm{ha} /$ jaar aangenomen als gemiddelde voor de fosfaatklassen laag en neutraal (respectievelijk 100 en $\left.90 \mathrm{~kg} \mathrm{P}_{2} \mathrm{O}_{5} / \mathrm{ha} / \mathrm{jaar}\right)$.
} 


\section{Graslandvernieuwing en fosfaat}

Tijdens de looptijd van de proef is het grasland niet vernieuwd, zodat het bodemfosfaat vanaf het begin in dezelfde bodemlagen blijft en goed te monitoren is. In de praktijk wordt op zand- en kleigrond echter minimaal iedere 5-10 jaar graslandvernieuwing uitgevoerd, al of niet in vruchtwisseling met een voedergewas. Daarbij wordt vaak een kerende grondbewerking uitgevoerd. Bij een kerende grondbewerking wordt een diepere bodemlaag naar boven gehaald en een oppervlakkige laag naar beneden gebracht. Wanneer grasland met een lage P-voorraad in de diepere lagen wordt gekeerd, is het P-Al-getal in 0-10 cm na die bewerking lager. Voorbeeld: uit bedrijfssysteemonderzoek op Waiboerhoeve (Lelystad) daalde het P-Al-getal 10 tot 35 eenheden door ploegen (Holshof, 2006).

In de proef zou scheuren op de locaties Lelystad en Zegveld een groter negatief effect op P-Al-getal in 0-10 cm hebben dan op de locaties Heino en Soerendonk. In hoeverre dit een negatief effect op de P-voorziening van het gewas heeft, is niet bekend.

Uit onderzoek op een groep praktijkbedrijven in project Management Duurzame Melkveebedrijven (MDM; 1992-1997; Den Boer \& Van Middelkoop, 1997) leek het verschil tussen de lagen 0-10 cm en 20-40 cm op zandgrond kleiner dan op klei- en veengrond. Dat is vergelijkbaar met onze veeljarige proef. Naar verwachting zou over het algemeen een plotselinge daling van het P-Al-getal na graslandvernieuwing op zandgrond kleiner zijn dan op klei- en veengrond. Mogelijk veroorzaakt een hogere frequentie van graslandvernieuwing dat $\mathrm{P}$ gelijkmatiger over de bouwvoor wordt verdeeld en het negatieve effect op het P-Al-getal door graslandvernieuwing kleiner wordt in de loop van de jaren. Of de ongelijkmatige ruimtelijke verdeling als gevolg van beweiding opgeheven wordt door grondbewerking en graslandvernieuwing is niet bekend. Er zal naar verwachting wel verandering in de ruimtelijke verdeling plaatsvinden, maar dit is niet gekwantificeerd.

Conclusie: bij graslandvernieuwing met een kerende grondbewerking wordt diepere grond met een lager P-Al-getal naar boven gehaald, waardoor het P-Al-getal in de bovengrond $(0-10 \mathrm{~cm})$ daalt en onder in de bouwvoor $(20-30 \mathrm{~cm})$ toeneemt. Dit effect zal met name optreden op kleigronden met een scherp P-profiel en kan mogelijk leiden tot een verhoogde fosfaatuitspoeling. Op zandgronden waar het P-Al-getal in de bouwvoor veelal homogeen is, zal een kerende grondbewerking geen of minder effect hebben op het P-Al-getal in de bovengrond.

\subsubsection{Bodemvruchtbaarheid bij evenwichtsbemesting}

De bodemvruchtbaarheid is gemonitord aan de hand van standaardbodemtesten (P-Al-getal, Pw-getal, $\mathrm{P}-\mathrm{CaCl}_{2}$ ) en additionele bodemtesten (P-ox, P-totaal, P-organisch). Het P-CaCl $2-$ en Pw-getal zijn een maat voor de fosfaatbeschikbaarheid en het P-Al-getal en P-ox gehalte vormen een maat voor de fosfaatcapaciteit (potentieel beschikbare fosfaatvoorraad). De P-AL-bepaling meet de hoeveelheid zwak gebonden fosfaat, terwijl de P-ox-bepaling daarnaast ook de hoeveelheid sterk gebonden fosfaat bepaalt.

Bij aanvang van de veldproeven bevonden alle percelen zich conform de indeling van het fosfaatgebruiksnormenstelsel in fosfaat-toestandklasse neutraal. Evenwichtsbemesting is niet voldoende op de fosfaattoestand neutraal op zand- en veengrond te handhaven. De afname in P-Algetal is alleen op locatie Heino statistisch significant. Op Soerendonk (zand) en Zegveld (veen) is een overschot van circa kg $20 \mathrm{P}_{2} \mathrm{O}_{5} / \mathrm{ha} / \mathrm{j}$ nodig om het P-Al-getal te handhaven terwijl hiervoor op Heino (zand) een overschot van circa $20-40 \mathrm{~kg} \mathrm{P}_{2} \mathrm{O}_{5} / \mathrm{ha} / \mathrm{j}$ nodig is. Op Lelystad (zeekleigrond) blijft de fosfaattoestand gehandhaafd bij evenwichtsbemesting. Op deze jonge zeekleigrond zijn de bodemvormende processen nog niet op evenwicht, waardoor o.a. het fosfaatgehalte en organischestofgehalte in de bovengrond toenemen. Deze uitkomsten kunnen daarom niet zonder meer vertaald worden naar oudere (rivier- of zee-)kleigronden. De $\mathrm{P}-\mathrm{CaCl}_{2}$-concentratie toont een sterke daling in de eerste jaren na aanvang van de proef. In de periode na 2004 is er, mede door de grote temporele variatie, geen trend zichtbaar in het verloop van de $\mathrm{P}-\mathrm{CaCl}_{2}$-concentratie.

Onder evenwichtsbemesting vindt een herverdeling plaats van fosfaat over de diverse fosfaatfracties. In een periode van 15-19 jaar neemt de hoeveelheid gebonden fosfaat (P-ox) met 15-30\% af. Deze afname gaat gepaard met een toename in de vastlegging van fosfaat in niet-beschikbare vormen (organische-fosfaat, zeer stabiele mineralen). De afname in P-ox is op alle locaties statistisch 
significant en na 15-19 jaar heeft zich nog geen nieuwe evenwichtssituatie ingesteld. De continue afname in het P-ox gehalte en het P-Al-getal vertaalt zich vooralsnog niet door naar een verdere afname in de $\mathrm{P}-\mathrm{CaCl}_{2}$-concentratie. Dit komt enerzijds omdat de $\mathrm{P}-\mathrm{CaCl}_{2}$-concentratie bij de huidige fosfaattoestand sterk wordt gebufferd en anderzijds omdat de $\mathrm{P}-\mathrm{CaCl}_{2}$-concentratie een grote temporele variatie vertoont. Binnen het meetbereik van het veldproeven zijn de gronden dus voldoende in staat om de fosfaatbeschikbaarheid en gewasopbrengst te handhaven, ondanks de afnemende fosfaatcapaciteit. Echter, op de langere termijn zal de fosfaatcapaciteit (P-ox, P-AL) verder dalen, waardoor het bufferend vermogen van de bodem uitgeput raakt en de fosfaatbeschikbaarheid daalt. Zodoende wordt verwacht dat evenwichtsbemesting op de langere termijn niet voldoende is om de fosfaatbeschikbaarheid en gewasopbrengsten te kunnen handhaven. De sterke fosfaatbuffering bij landbouwkundige relevante $\mathrm{P}-\mathrm{CaCl}_{2}$-waarden impliceert eveneens dat een relatief hoge reparatiegift vereist is om de $\mathrm{P}-\mathrm{CaCl}_{2}$-concentratie indien gewenst weer te verhogen. Continueren van de veldproeven is noodzakelijk om deze verwachtingen te kunnen toetsen.

Het organische-stofgehalte in de wortelzone van grasland blijft op peil wanneer evenwichtsbemesting wordt uitgevoerd met runderdrijfmest. Op basis van de proef kunnen geen uitspraken worden gedaan over het verloop in organische-stofgehalte bij bemesting met andere mestsoorten waaronder varkensmest, waarmee beduidend minder organische stof wordt aangevoerd.

\subsubsection{Effecten op fosfaatuitspoeling}

Fosfaatconcentraties (ortho-P en totaal-P) in het bodemvocht zijn gemonitord in de periode 19962011. Monitoring van de fosfaatuitspoeling is vanwege budgettaire redenen in 2011 gestopt. Op Soerendonk nemen de fosfaatconcentraties gedurende de eerste jaren na aanvang van evenwichtsbemesting af. Op de langere termijn en op de andere drie locaties wordt in de tijd geen afname in fosfaatconcentraties waargenomen.

Met behulp van een hydrologisch model is de jaarlijkse uitspoeling bepaald. De jaargemiddelde fosfaatuitspoeling ${ }^{13}$ varieert van $1,0 \mathrm{~kg} \mathrm{P}_{2} \mathrm{O}_{5} \mathrm{ha}^{-1} \mathrm{j}^{-1}$ op kleigrond tot $11,4 \mathrm{~kg} \mathrm{P}_{2} \mathrm{O}_{5} \mathrm{ha}^{-1} \mathrm{j}^{-1}$ op zandgrond. Op de klei- en zandgrond wordt de fosfaatuitspoeling vanuit de wortelzone grotendeels bepaald door de fosfaatconcentraties in het bodemvocht onder in de wortelzone $(20-30 \mathrm{~cm})$. Omdat de effecten van fosfaatoverschotten zich beperken tot de bovenste $10 \mathrm{~cm}$ van de bodem, is de fosfaatuitspoeling gelijk onder evenwichtsbemesting en overschotbemesting. Alleen op de veengrond, waar de uitspoeling grotendeels wordt bepaald door laterale uitspoeling uit de wortelzone, is de fosfaatuitspoeling lager bij evenwichtsbemesting dan bij overschotbemesting.

Fosfaatconcentraties in het bodemvocht bestaan voor meer dan 75-92\% uit organisch-P en voor $8-25 \%$ uit ortho-P. Het P-ox-gehalte is een goede indicator voor de uitspoeling van ortho-P. Bij evenwichtsbemesting daalt het P-ox-gehalte waardoor verwacht kan worden dat de uitspoeling van ortho-P op termijn afneemt. Anderzijds kan de waargenomen toename in het organisch-P-gehalte in de bodem leiden tot een toename in de uitspoeling van organisch fosfaat. Het netto-effect op de lange-termijn-fosfaatuitspoeling is daarmee onzeker en kan alleen beantwoord worden door langdurige monitoring van fosfaatuitspoeling op proefvelden.

Het uitmijnen van fosfaat, waarbij géén fosfaatbemesting wordt toegepast, leidt in de bovenste $10 \mathrm{~cm}$ van de bodem tot een afname in de fosfaatconcentraties in het bodemvocht ten opzichte van evenwichtsbemesting. Echter, onder in de wortelzone zijn de fosfaatconcentraties in het bodemvocht bij uitmijnen vergelijkbaar met de concentraties bij evenwichtsbemesting, met uitzondering van proefveld Heino. Op (klei)grond met een ondiep fosfaatprofiel heeft uitmijnen geen effect op de fosfaatuitspoeling, omdat de effecten van uitmijnen zich beperken tot de bovenste $10 \mathrm{~cm}$. Ook op (zand)gronden met een diep fosfaatprofiel heeft uitmijnen geen effect op de fosfaatuitspoeling, mits de bodem na verloop van tijd wordt geploegd, zodat de fosfaatrijke ondergrond wordt vermengd met de verarmde bovengrond. Op veengronden met een grote bijdrage van laterale uitspoeling vanuit de bovengrond is uitmijnen wel effectief.

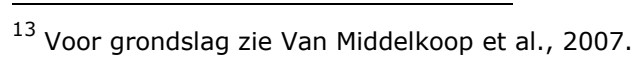




\section{$4 \quad$ Resultaten Bouwlandproeven}

\subsection{Gewasopbrengsten}

\subsubsection{Lelystad (Fosfaattoestandenproef)}

De vier objecten (P1-P4) kenmerken zich door sterk uiteenlopende fosfaattoestanden (laag-hoog) welke zijn ontstaan door jarenlange bemesting met breed bereik aan fosfaatdoseringen $(0,70,140$, $280 \mathrm{~kg} / \mathrm{ha} / \mathrm{jaar}$ ). Object P1 kenmerkt zich door een lage fosfaattoestand, object P2 door een neutrale fosfaattoestand en objecten P3 en P4 door een hoge fosfaattoestand (peiljaar 2005, zie par. 4.3.1). In 2005 is de proefopzet veranderd om het effect van fosfaattoestand i.c.m. fosfaatbemesting te kunnen toetsen. Sindsdien ontvangt de helft van de objecten géén bemesting (onbemest, oftewel uitmijnen), terwijl de bemesting op de andere helft ongewijzigd is gebleven.

Tabel 4.1 geeft de jaarlijkse relatieve marktbare opbrengst bij een oplopende fosfaattoestand (P1-P4) en bij uitmijnen (onbemest) en bemesting (70-280 kg/ha) in de periode 2001-2016. Hierbij is de opbrengst relatief gesteld t.o.v. object P2-bemest omdat dit object een neutrale fosfaatstatus heeft. In de Tabellen 4.2 en 4.3 is de gemiddelde relatieve marktbare opbrengst weergegeven gemiddeld naar de per fosfaatbehoefte ingedeelde gewasgroepen. Hierbij is onderscheid gemaakt in de perioden 20012016 en 2006-2016 in verband met de verandering van proefopzet sinds 2005.

Er waren verschillen in fosfaatreactie tussen jaren en gewassen (Tabel 4.1). De meest fosfaatbehoeftige gewassen die werden geteeld (die uit gewasgroep 1: aardappel, zaaiui en doperwt) reageerden het sterkst op de verschillen in fosfaattoestand en -bemesting, aardappel nog wat sterker dan zaaiui. Het jaar 2005 is buiten beschouwing gelaten, omdat toen grote wateroverlast optrad in de proef, met lage aardappelopbrengsten en een relatief grote veldvariatie in opbrengst tot gevolg.

Gemiddeld over de periode 2001-2016 was de opbrengst in de gewasgroepen 1 en 2 bij P1-onbemest significant lager dan bij de P2-, P3- en P4-bemest (Tabel 4.2). Tussen P2-, P3- en P4-bemest waren er geen significante opbrengstverschillen. In gewasgroep 3 waren de opbrengstverschillen tussen de vier objecten niet significant. Daarentegen waren in gewasgroep 4 wel significante verschillen. Hier was de opbrengst bij P1-onbemest significant lager dan bij P2-bemest, maar ook bij P3-bemest en P4-bemest. Voor deze merkwaardige opbrengstreactie is geen verklaring. Het betrof slechts twee proefjaren met het gewas wintertarwe. Normaliter reageren gewassen in groep 4 niet of nauwelijks op fosfaatbemesting.

Over de periode 2006-2016 waren de gemiddelde opbrengstverschillen tussen de objecten bij gewasgroep 1 bij onbemest (uitmijnen) t.o.v. P2, P3 en P4 groter dan bij bemest. Deze onderlinge verschillen per P-toestand bij onbemest waren alle significant. De gemiddelde opbrengst bij P3onbemest was significant lager dan bij P2-bemest en P3-bemest. Bij de andere gewasgroepen was het verschil tussen bemest en onbemest kleiner en waren de onderlinge verschillen per P-toestand bij onbemest niet significant.

Gewassen uit gewasgroep 0 werden niet geteeld in de periode 2001-2016.

De handhaving van een landbouwkundig vereiste fosfaattoestand van de bodem blijkt in deze proef vooral van belang voor de gewassen met een hoge tot matig hoge fosfaatbehoefte (gewasgroepen 1 en 2). Bij P-toestand P2 met een jaarlijkse gift van $70 \mathrm{~kg} \mathrm{P}_{2} \mathrm{O}_{5}$ per ha was de opbrengst gemiddeld genomen niet significant lager dan bij hogere P-toestand. In sommige individuele jaren was deze wel lager: met aardappel in 2010 en suikerbiet in 2016. Verder blijkt dat een verse fosfaatgift voor fosfaatbehoeftige gewassen van belang is. Weglaten ervan leidde alleen bij de allerhoogste P-toestand (P4) niet tot opbrengstderving, terwijl anderzijds met toediening van een verse fosfaatgift bij de lagere toestand P2 voor de opbrengst lijkt te kunnen worden volstaan. 


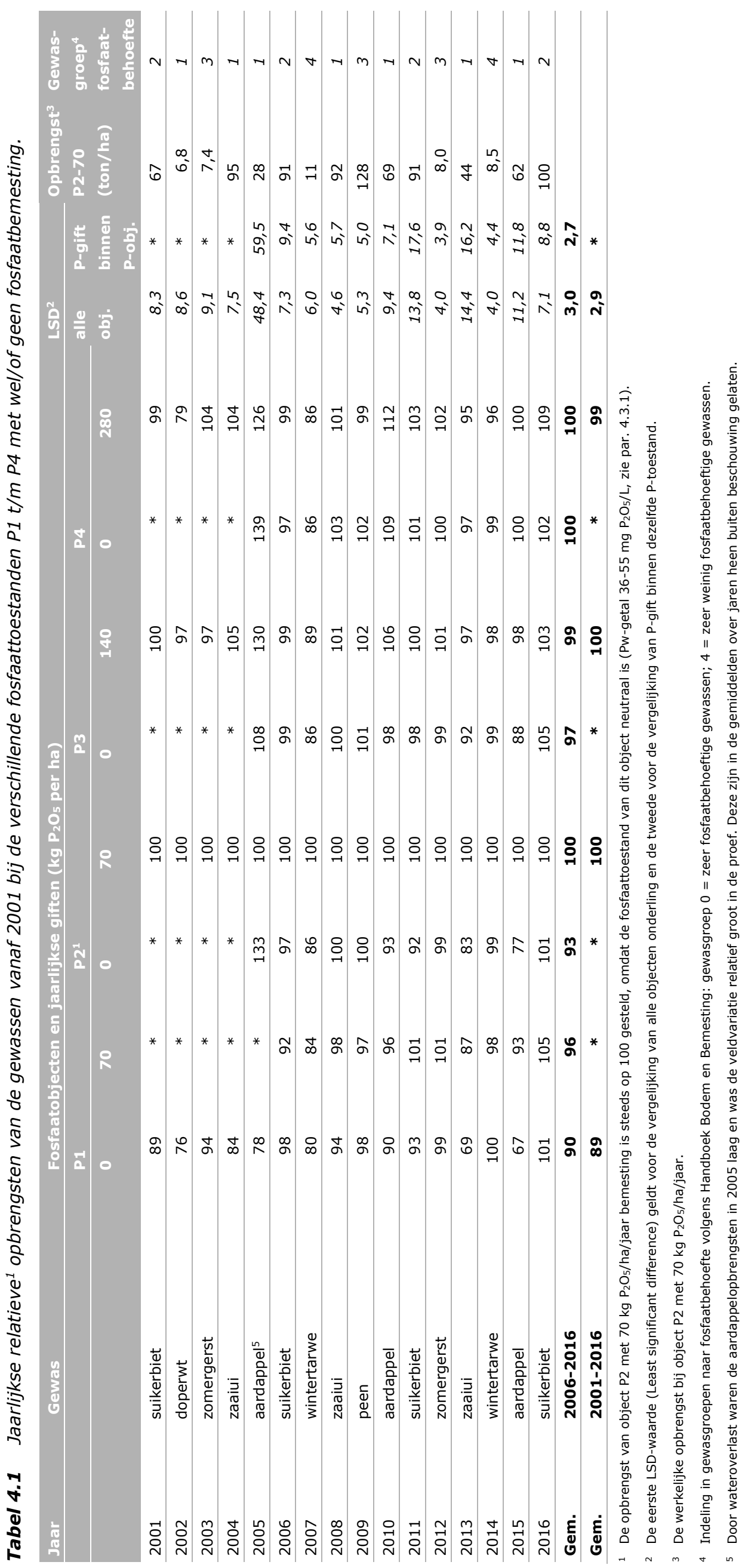


Tabel 4.2 Gemiddelde relatieve opbrengsten per gewasgroep vanaf 2001 bij de verschillende fosfaattoestanden P1 t/m P4 (exclusief 20052) met standaardfout (s.e.) en aantal proefjaren ( $n$ ).

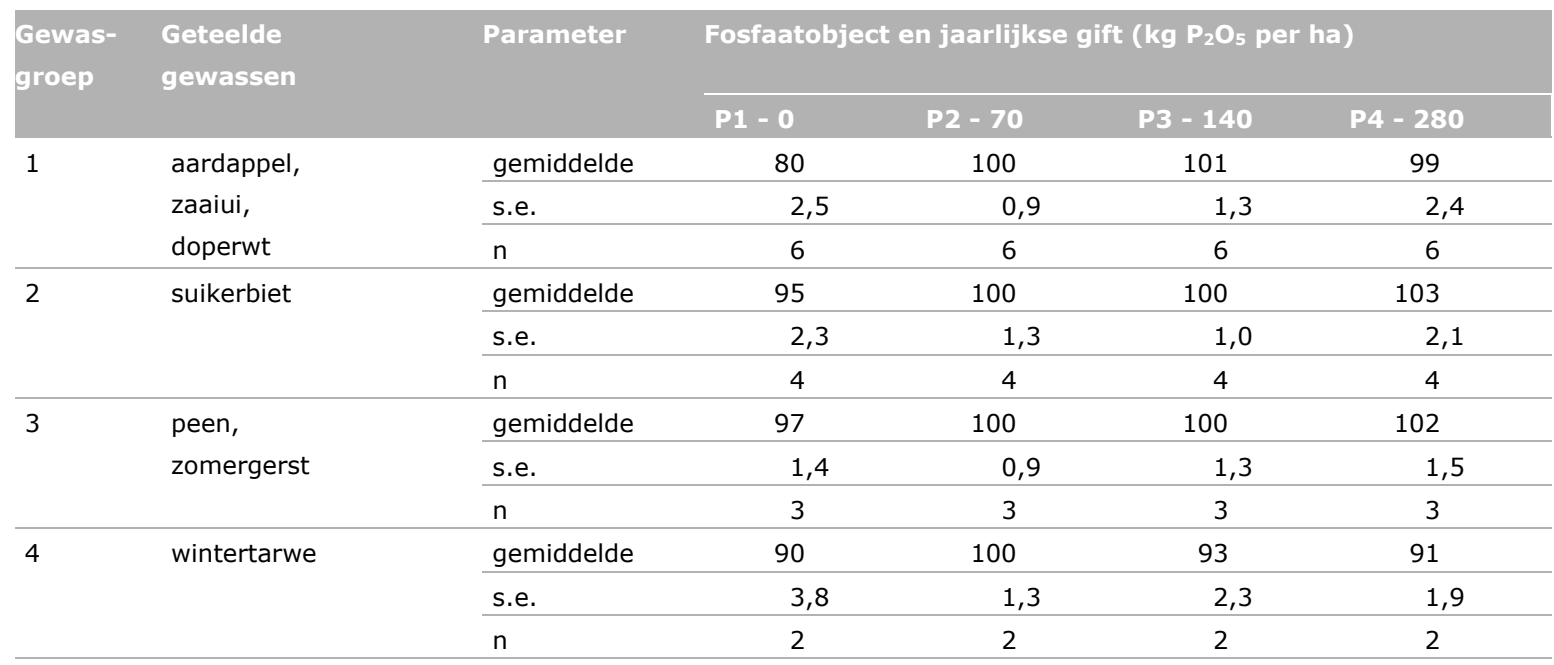

Tabel 4.3 Gemiddelde relatieve ${ }^{1}$ opbrengsten per gewasgroep vanaf 2006 bij de verschillende fosfaattoestanden en giften na aanbrengen van behandelingen zonder fosfaatbemesting (O) en bij P1 met een behandeling met $70 \mathrm{~kg} \mathrm{P}_{2} \mathrm{O}_{5} / \mathrm{ha}(\mathrm{P1}-70)$ met standaardfout (s.e.) en aantal proefjaren ( $n$ ).

\begin{tabular}{|c|c|c|c|c|c|c|c|c|c|c|}
\hline $\begin{array}{l}\text { Gewas- } \\
\text { groep }\end{array}$ & $\begin{array}{l}\text { Geteelde } \\
\text { gewassen }\end{array}$ & Parameter & \multicolumn{8}{|c|}{ Fosfaatobjecten en jaarlijkse giften ( $\mathrm{kg} \mathrm{P}_{2} \mathrm{O}_{5}$ per ha) } \\
\hline \multirow[t]{3}{*}{1} & \multirow[t]{3}{*}{ aardappel, zaaiui } & gemiddelde & 80 & 94 & 88 & 100 & 95 & 101 & 102 & 102 \\
\hline & & s.e. & 3,5 & 2,0 & 2,6 & 1,4 & 2,2 & 1,6 & 2,1 & 2,2 \\
\hline & & $\mathrm{n}$ & 4 & 4 & 4 & 4 & 4 & 4 & 4 & 4 \\
\hline 2 & suikerbiet & $\mathrm{n}$ & 3 & 3 & 3 & 3 & 3 & 3 & 3 & 3 \\
\hline \multirow[t]{3}{*}{3} & \multirow[t]{3}{*}{ peen, zomergerst } & gemiddelde & 98 & 99 & 100 & 100 & 100 & 102 & 101 & 100 \\
\hline & & s.e. & 1,1 & 1,4 & 1,1 & 0,3 & 1,1 & 1,6 & 1,5 & 1,3 \\
\hline & & $\mathrm{n}$ & 2 & 2 & 2 & 2 & 2 & 2 & 2 & 2 \\
\hline 4 & wintertarwe & $\mathrm{n}$ & 2 & 2 & 2 & 2 & 2 & 2 & 2 & 2 \\
\hline
\end{tabular}

1 De opbrengst van object P2 met $70 \mathrm{~kg} \mathrm{P} \mathrm{O}_{5} / \mathrm{ha} /$ jaar bemesting is steeds op 100 gesteld, omdat de fosfaattoestand van dit object neutraal is (Pw-getal 36-55 mg $\mathrm{P}_{2} \mathrm{O}_{5} / \mathrm{L}$, zie par. 4.3.1).

\subsubsection{Marknesse (fosfaathoeveelhedenproef)}

Bij de fosfaathoeveelheden-veldproef te Marknesse zijn fosfaatgiften 0, 80, 160 en $240 \mathrm{~kg} \mathrm{P}_{2} \mathrm{O}_{5}$ vanaf 1972 jaarlijks toegediend. Behandelingen gebaseerd op evenwichtsbemesting werden vanaf 1990 opgenomen, waardoor gegevens van opbrengsten over effecten ervan vanaf 1991 beschikbaar zijn. De hoogte van de fosfaatgift bij evenwichtsbemesting varieert per jaar, waardoor er ook variatie is ontstaan in de opbrengsten van eenzelfde gewas per jaar. Voor dit syntheserapport worden daarom de relatieve opbrengsten gegeven. De gegevens zijn gegroepeerd volgens de indeling van gewasgroepen van het Handboek Bodem en Bemesting ${ }^{14}$. Om de jaarlijkse variatie in fosfaatevenwichtsbemesting te ondervangen, worden in deze paragraaf de opbrengsten vergeleken met die van de hoogste fosfaatgift van $240 \mathrm{~kg} \mathrm{P}_{2} \mathrm{O}_{5} /$ ha $(=100 \%)$.

Tabel 4.4 geeft de gemiddelde relatieve opbrengsten per gewasgroep voor de jaarlijks constante fosfaatgiften $\left(0,80,160\right.$ en $\left.240 \mathrm{~kg} \mathrm{P} \mathrm{O}_{5} / \mathrm{ha}\right)$ voor de periode 1972-2016. Het achterwege laten van

\footnotetext{
${ }^{14}$ http://www.handboekbodemenbemesting.nl/nl/handboekbodemenbemesting.htm
} 
fosfaatbemesting leidt bij alle gewasgroepen tot opbrengstdaling, maar leidt niet tot een misoogst. Bij geen van de gewasgroepen treden significante verschillen op in opbrengst bij een jaarlijkse constante fosfaatgift van 80, 160 en $240 \mathrm{~kg} \mathrm{P}_{2} \mathrm{O}_{5} / \mathrm{ha}$.

Tabel 4.4 Gemiddelde relatieve opbrengsten per gewasgroep voor de veldproef te Marknesse (IB0013) voor de periode 1972-2016 bij jaarlijkse fosfaatgiften van 0, 80, 160 en $240 \mathrm{~kg} P_{2} \mathrm{O}_{5} / \mathrm{ha}$ als superfosfaat met standaardfout (s.e.) en aantal proefjaren (n).

\begin{tabular}{|c|c|c|c|c|c|}
\hline \multirow[t]{2}{*}{ Gewasgroep en geteelde gewassen } & \multirow[t]{2}{*}{ Parameter } & \multicolumn{4}{|c|}{ Fosfaatgift, kg $\mathrm{P}_{2} \mathrm{O}_{5} / \mathrm{ha}$} \\
\hline & & 0 & 80 & 160 & 240 \\
\hline 1 & gemiddelde & 89,4 & 97,6 & 98,4 & 100 \\
\hline $\begin{array}{l}\text { Consumptieaardappel, pootaardappel, ui, } \\
\text { doperwt }\end{array}$ & $\mathrm{n}$ & 15 & 15 & 15 & 15 \\
\hline 2 & gemiddeld & 91,5 & 99,2 & 99,3 & 100 \\
\hline Suikerbiet & $\mathrm{n}$ & 9 & 9 & 9 & 9 \\
\hline 3 & gemiddelde & 91,6 & 100,1 & 99,9 & 100 \\
\hline \multirow[t]{2}{*}{ Zomergerst } & se & 5,3 & 5,5 & 3,8 & 0 \\
\hline & $\mathrm{n}$ & 10 & 10 & 10 & 10 \\
\hline
\end{tabular}

Het effect van evenwichtsbemesting (M) wordt vanaf 1990 bestudeerd. Per jaar wordt de gewasafvoer gecompenseerd door een bemestingsgift gelijk aan de afvoer (= evenwicht $(\mathrm{M})$ ), tweemaal (2M) of driemaal (3M) toe te dienen. Tabel 4.5 geeft de gemiddelde relatieve opbrengsten per gewasgroep voor de jaarlijks constante fosfaatgiften en de jaarlijks variabele fosfaatgiften $M, 2 M$ en $3 M$ voor de periode 1991-2016. Tussen haakjes is bij M, 2M en 3M de gemiddelde fosfaatgift over deze periode gegeven. De gemiddelde fosfaatafvoer met het gewas bedroeg $52 \mathrm{~kg} \mathrm{P}_{2} \mathrm{O}_{5} / \mathrm{ha} / \mathrm{jaar}$ over de periode

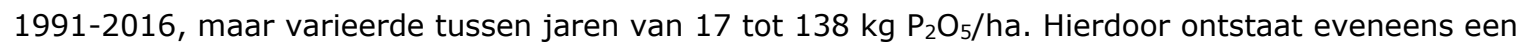
grote variatie in de fosfaatbemesting in het opvolgende jaar. Die variatie werkt door in de relatieve opbrengsten, omdat de giften $\mathrm{M}$ tot en $3 \mathrm{M}$ soms lager zijn dan $80 \mathrm{~kg} \mathrm{P}_{2} \mathrm{O}_{5} /$ ha en soms zijn de $3 \mathrm{M}$ giften hoger dan $160 \mathrm{~kg} \mathrm{P}_{2} \mathrm{O}_{5} / \mathrm{ha}$. De opbrengsten bij evenwichtsbemesting zijn hoger t.o.v. behandelingen zonder bemesting. Bij gewasgroep 1 geeft evenwichtsbemesting een derving van de opbrengst ten opzichte van bemesting met $80 \mathrm{~kg} \mathrm{P} \mathrm{O}_{5} / \mathrm{ha}$. Er is ook derving bij gewasgroep 2, maar deze is geringer en niet significant. Bij gewasgroepen 3 en 4 wordt geen opbrengstdervingen vastgesteld. 
Tabel 4.5 Gemiddelde relatieve ${ }^{1}$ opbrengst per gewasgroep voor de veldproef te Marknesse (B0013) over de periode 1991-2016 bij jaarlijkse fosfaatgiften van 0, 80, 160 en $240 \mathrm{~kg} \mathrm{P}_{2} \mathrm{O}_{5} / \mathrm{ha}$ als superfosfaat en bij evenwichtsbemesting (M) met standaardfout (s.e.) en aantal proefjaren ( $n$ ).

\begin{tabular}{|c|c|c|c|c|c|c|c|c|}
\hline \multirow[t]{3}{*}{ Gewasgroep } & \multirow[t]{3}{*}{ Parameter } & \multicolumn{7}{|c|}{ Fosfaatgift, kg $\mathrm{P}_{2} \mathrm{O}_{5} / \mathrm{ha}$} \\
\hline & & \multirow[t]{2}{*}{0} & \multirow[t]{2}{*}{80} & \multirow[t]{2}{*}{160} & \multirow[t]{2}{*}{240} & \multirow{2}{*}{$\begin{array}{c}M \\
(52)^{2}\end{array}$} & \multirow{2}{*}{$\begin{array}{r}2 M \\
(103)^{2}\end{array}$} & \multirow{2}{*}{$\begin{array}{r}3 \mathrm{M} \\
(155)^{2}\end{array}$} \\
\hline & & & & & & & & \\
\hline \multirow{2}{*}{$\begin{array}{l}\text { Aardappel, pootaardappel, ui, } \\
\text { doperwt }\end{array}$} & s.e. & 8,3 & 5,3 & 7,1 & 0 & 5,9 & 6,4 & 5,2 \\
\hline & $\mathrm{n}$ & 10 & 10 & 10 & 10 & 10 & 10 & 10 \\
\hline \multirow[t]{2}{*}{ Suikerbiet } & s.e. & 4,9 & 3,4 & 6,8 & 0 & 4,4 & 3,9 & 4,3 \\
\hline & $\mathrm{n}$ & 5 & 5 & 5 & 5 & 5 & 5 & 5 \\
\hline 3 & gemiddelde & 92,5 & 102,2 & 101,2 & 100 & 98,7 & 101,2 & 102,5 \\
\hline Zomergerst & s.e. & 4,6 & 2,0 & 1,9 & 0 & 3,8 & 3,0 & 5,5 \\
\hline Wintertarwe, zomertarwe & $\mathrm{n}$ & 5 & 5 & 5 & 5 & 5 & 5 & 5 \\
\hline \multicolumn{9}{|c|}{1 Relatief t.o.v. de opbrengst bij 240 kg $\mathrm{P}_{2} \mathrm{O}_{5} / \mathrm{ha}$. } \\
\hline \multicolumn{9}{|c|}{$M=$ evenwichtsbemesting, $2 \mathrm{M}$ en $3 \mathrm{M}$ ontvangen respectievelijk twee- en driemaal de hoeveelheid fosfaat bij evenwichtsbemesting. De } \\
\hline
\end{tabular}

\subsubsection{Marknesse (fosfaattoestandenproef)}

Op deze proeflocatie zijn in de periode 2000-2016 geen opbrengsten bepaald (slapende proef).

\subsubsection{Wijster (fosfaathoeveelhedenproef)}

De fosfaathoeveelhedenproef kent verschillende minerale fosfaatmeststoffen die op hun veeljarige werking worden getoetst. De proef kent een periode 1998-2006 waarin geen opbrengsten werden bepaald, waardoor ook geen chemisch gewasonderzoek kon worden uitgevoerd. Grondonderzoek werd in die periode wel uitgevoerd.

Tabel 4.6 geeft de gemiddelde relatieve opbrengstderving per gewasgroep over de periode 1972-2016 per fosfaatvorm en per fosfaatgift. De fosfaattoestand was hierbij laag tot neutraal.

Door fosfaatbemesting te onthouden, daalde de opbrengst t.o.v. de referentie van $240 \mathrm{~kg} \mathrm{P}_{2} \mathrm{O}_{5} / \mathrm{ha} / \mathrm{jaar}$. De daling werd groter met voortschrijdende jaren (Figuur 4.1). De variatie tussen jaren was aanzienlijk, hetgeen tot uitdrukking komt in de relatief hoge waarden van de standaardafwijking (s.e.). Een voorbeeld daarvan is gewasgroep 4, dat slechts met 2 proefjaren vertegenwoordigd is en de hoogste s.e. heeft bij de niet met fosfaatbemeste objecten. Statistische analyses (ANOVA) per jaar tonen vaak wel een positief effect van fosfaatbemesting t.o.v. onbemest aan, maar ook dat verschillen tussen met fosfaatbemeste behandelingen vaak niet significant zijn. Gemiddeld over de jaren neemt de opbrengst toe met hoger wordende fosfaatgift, ongeacht de fosfaatmeststofvorm. Het bemestingseffect is duidelijk sterker op deze zandgrond in vergelijking met de zavelgronden in Marknesse en Lelystad, waar geen toename in gewasopbrengst wordt gevonden bij bemesting met $80 \mathrm{~kg} \mathrm{P}_{2} \mathrm{O}_{5} / \mathrm{ha}$ of meer.

Meststoffen van thermische productiemethoden gloeifosfaat (Rhekaphos, Rhenania en het mengsel van Rhenania met K-60) en slakkenmeel (slakkenmeel en Thomaskali) hebben een vergelijkbare werking als superfosfaat, natuurfosfaat blijft achter. Een gift van $90 \mathrm{~kg} \mathrm{P}_{2} \mathrm{O}_{5} /$ ha als natuurfosfaat vertoonde veelal geen hogere opbrengst dan de onbemeste behandeling. Gewasgroep 2 wordt alleen vertegenwoordigd door suikerbiet. Dit gewas reageerde ook op de neutraliserende waarde, die als nevenbestanddeel in de meststoffen met slakkenmeel (slakkenmeel en Thomaskali) voorkomt. De $\mathrm{pH}$ stijgt gelijktijdig met fosfaatbemesting (eigenschap meststof); een hogere $\mathrm{pH}$ is gunstig voor de teelt van suikerbiet. Het effect van fosfaat en van zuur-neutraliserende waarde kan bij deze meststof niet gescheiden worden (verstrengeling). 


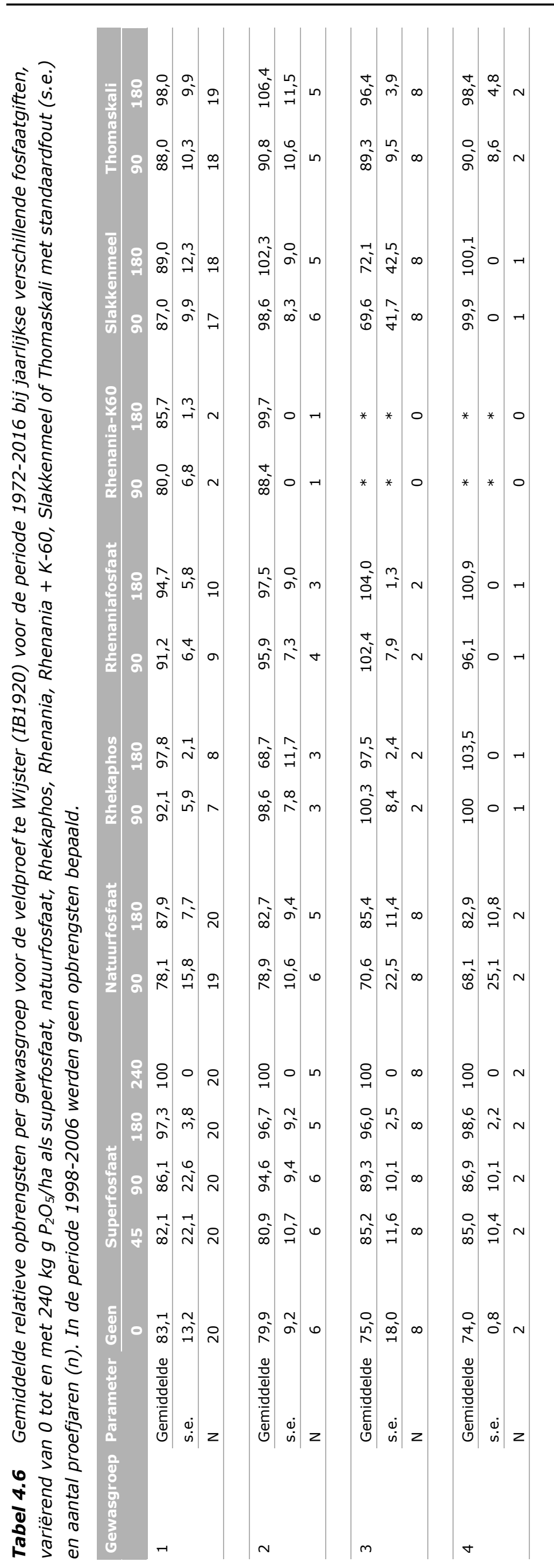

Wageningen Environmental Research Rapport 2906 | 61 
De rotatie was aanvankelijk een standaardbouwplan voor Drentse zandgronden met tweemaal fabrieksaardappel, suikerbiet en een vierde gewas, meestal een graangewas. Fabrieksaardappel werd tot en met 2004 geteeld waarna het standaardbouwplan werd verlaten en vaak vervangen werd door een industrieteelt (doperwt), maar nog vaker door snijmaïs, omdat de proefveldhouder dat zo beschikte. In de periode 2008-2012 werd viermaal snijmaïs geteeld, hetgeen leidde tot een forse opbrengstdaling bij dit gewas. Die daling is niet een gevolg van fosfaatbemesting, maar wordt toegeschreven aan een verslechterde biologische bodemvruchtbaarheid (bodemziekte). Daarnaast hadden onbemeste veldjes in deze periode een zwaardere competitie met onkruid dan goed bemeste veldjes, hetgeen ook de opbrengst drukte. Snijmais is vanaf 2013 niet meer geteeld. In plaats daarvan zijn andere granen geteeld.

\section{Conclusie opbrengsten}

Akkerbouw- en vollegrondsgroentegewassen reageren op fosfaatbemesting en fosfaattoestand. De gewasreactie is beperkt. Het achterwege laten van fosfaatbemesting leidt niet tot een misoogst, maar geeft wel opbrengstderving tot circa $26 \%$ afhankelijk van het gewas, grondsoort en fosfaattoestand. De gewasreactie op fosfaatbemesting en fosfaattoestand op zandgrond is groter dan die op kleigrond. Dit effect wordt veroorzaakt doordat de zandgrond van Wijster armer is aan fosfaat dan de zavellocaties. Opbrengstderving op de zavels is het grootst bij gewassen van gewasgroep 1 conform het Handboek bemesting (aardappel, zaaiui). De opbrengstderving neemt af bij gewasgroep 2 (suikerbiet) en daaropvolgende gewasgroepen 3 (zomergerst, peen op klei) en 4 (tarwe). De behandeling zonder fosfaatbemesting op zandgrond heeft een dusdanig lage fosfaattoestand dat bij alle gewasgroepen opbrengstderving optreedt. Evenwichtsbemesting op zavel kan bij gewasgroep 1 leiden tot een opbrengstderving tot $4 \%$, bij overige gewasgroepen is dit minder dan $1 \%$. Op de zandgrond zijn de opbrengstdervingen groter, tot $18 \%$.

\subsection{Fosfaatgehalten, fosfaataanvoer en -overschot}

\subsubsection{Lelystad (fosfaattoestandenproef)}

In Tabel 4.7 zijn de gemiddelde fosforgehalten in het gewas weergegeven over de periode 2001-2016 bij oplopende fosfaattoestand en bijhorende fosfaatdosering (P1-P4). Het fosforgehalte in het gewas neemt significant toe naarmate de P-toestand en P-dosering toenemen. Omdat objecten met een hoge P-toestand eveneens een hogere P-dosering ontvangen, kan geen onderscheid gemaakt worden tussen beide factoren (i.e. toestand versus dosering). De mate van de interactie verschilt per gewas (significant interactie-effect tussen P-toestand en gewas). Bij aardappel, zaaiui, doperwt en peen is het effect sterker dan bij suikerbiet, zomergerst en wintertarwe. 
Tabel 4.7 Gemiddelde fosforgehalten van gewas ( $\mathrm{g} P / \mathrm{kg}$ droge stof in het geoogste product) op objecten met oplopende fosfaattoestand en bijhorende fosfaatgift (P1-P4). Data vanaf 2001 (exclusief 2005) met standaardafwijking (s.e.) en aantal jaren ( $n)^{1}$.

\begin{tabular}{|c|c|c|c|c|c|}
\hline \multirow[t]{2}{*}{ Gewas } & \multirow[t]{2}{*}{ Parameter } & \multicolumn{4}{|c|}{ Fosfaattoestanden en jaarlijkse giften ( $\mathrm{kg} \mathrm{P}_{2} \mathrm{O}_{5}$ per ha) } \\
\hline & & P1 - 0 & P2 - 70 & P3 - 140 & $P 4-280$ \\
\hline \multirow[t]{2}{*}{ aardappel } & gemiddelde & 1,53 & 1,74 & 2,01 & 2,55 \\
\hline & $\mathrm{n}$ & 2 & 2 & 2 & 2 \\
\hline \multirow[t]{2}{*}{ zaaiui } & gemiddelde & 2,70 & 2,94 & 3,08 & 3,26 \\
\hline & $n$ & 3 & 3 & 3 & 3 \\
\hline \multirow[t]{3}{*}{ doperwt } & gemiddelde & 3,28 & 3,48 & 3,73 & 4,00 \\
\hline & s.e. & 0,13 & 0,10 & 0,17 & 0,14 \\
\hline & $n$ & 1 & 1 & 1 & 1 \\
\hline \multirow[t]{3}{*}{ zomergerst } & gemiddelde & 3,46 & 3,59 & 3,66 & 3,75 \\
\hline & s.e. & 0,10 & 0,06 & 0,08 & 0,08 \\
\hline & $\mathrm{n}$ & 2 & 2 & 2 & 2 \\
\hline \multirow[t]{3}{*}{ peen } & gemiddelde & 1,98 & 2,38 & 2,73 & 3,00 \\
\hline & s.e. & 0,05 & 0,08 & 0,06 & 0,09 \\
\hline & $\mathrm{n}$ & 1 & 1 & 1 & 1 \\
\hline \multirow[t]{3}{*}{ wintertarwe } & gemiddelde & 3,38 & 3,58 & 3,64 & 3,58 \\
\hline & s.e. & 0,08 & 0,07 & 0,05 & 0,07 \\
\hline & $\mathrm{n}$ & 2 & 2 & 2 & 2 \\
\hline
\end{tabular}

1 Door wateroverlast waren de aardappelopbrengsten in 2005 laag en was de veldvariatie relatief groot in de proef. Deze zijn in de gemiddelden over jaren heen buiten beschouwing gelaten.

In Figuur 4.1 is per gewas en object de gemiddelde fosfaatafvoer weergegeven vanaf 2001 bij de objecten P1-onbemest en P2-, P3- en P4-bemest en voor de objecten P1-bemest en P2-, P3- en P4bemest. De behandeling heeft een significant effect op de fosfaatafvoer met het geoogste product. Deze was gemiddeld genomen hoger bij behandelingen met een hogere fosfaattoestand en fosfaatbemesting, maar het verschilde per jaar en gewas (significant interactie-effect tussen P-toestand, gewas en jaar). Het effect van behandeling op de fosfaatafvoer was het sterkst bij aardappel en peen. Bij doperwt had de behandeling geen effect op de fosfaatafvoer. De afvoer bij doperwt is laag. Bij wintertarwe leidde een hogere fosfaattoestand dan P2 niet tot een hogere maar eerder lagere afvoer, wat samenhangt met de lagere opbrengst bij P3 en P4. Ook uitmijnen leidde bij aardappel en peen tot een lagere fosfaatafvoer, maar niet bij overige gewassen. Fosfaatoverschotten worden gegeven in Figuur 4.2. In 2006 werden bemeste veldjes opgedeeld naar continering van de bemesting en op nawerking. Onbemeste veldjes werden opgedeeld in een bemest en een continuerende onbemest deel. Onbemest leidt een hogere fosfaattoestand tot een hogere fosfaatafvoer. Behandelingen P3 en P4 leiden tot grote fosfaatoverschotten.

Het effect van fosfaattoestand en -bemesting op het fosforgehalte en de fosfaatopname of -afvoer was sterker dan het effect op de opbrengst. Bij de hogere P-toestanden (P3 en P4) is er sprake van luxeconsumptie van fosfaat, dat wil zeggen dat het gewas wel fosfaat opneemt, maar dat er geen toename meer is in de (drogestof)opbrengst. 


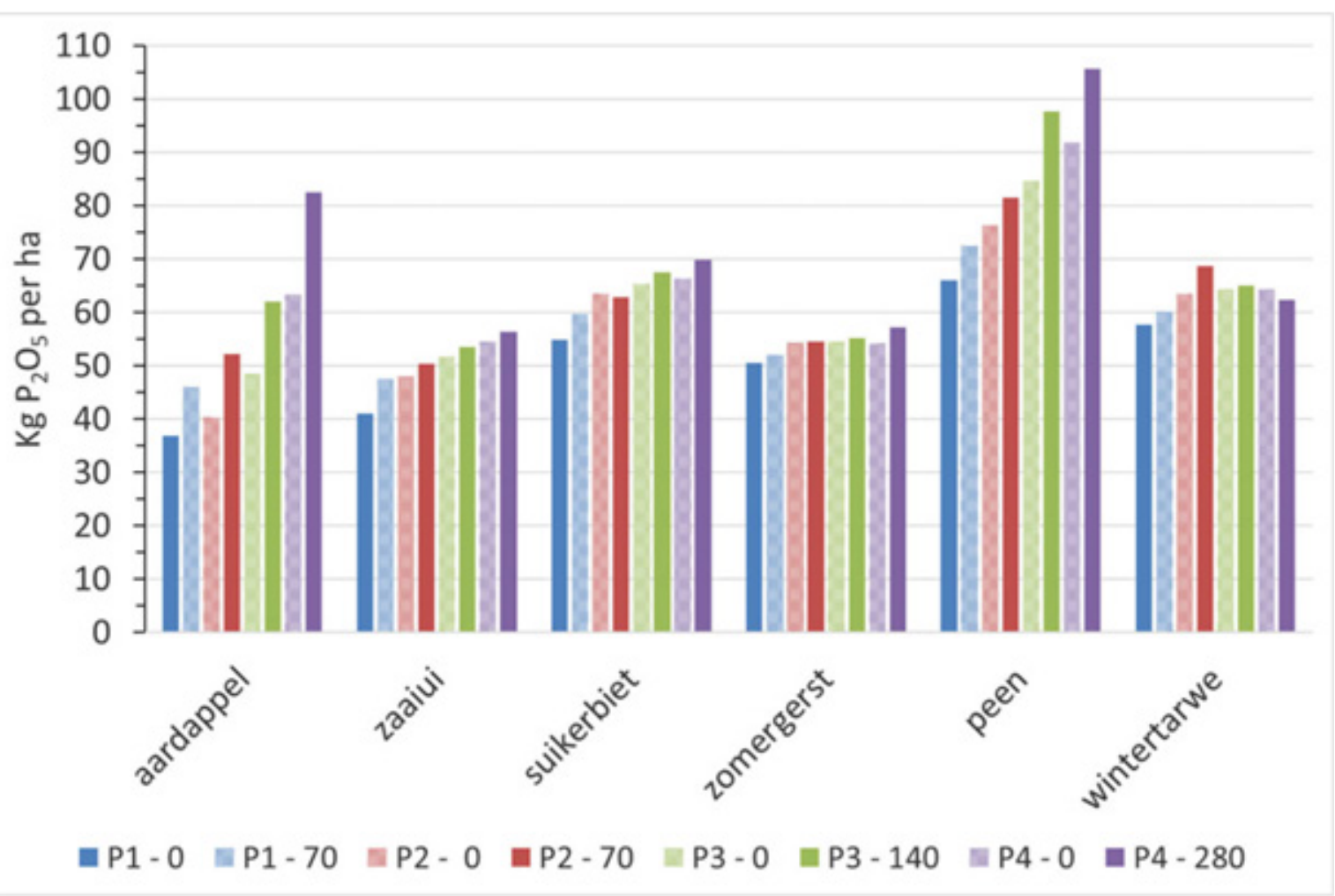

Figuur 4.1 Gemiddelde fosfaatafvoer met bijhorende fosfaatgift per gewas per ha per jaar en gemiddelde fosfaatafvoer bij uitmijnen per gewas per ha per jaar, gemeten vanaf 2006 bij de verschillende fosfaattoestanden.

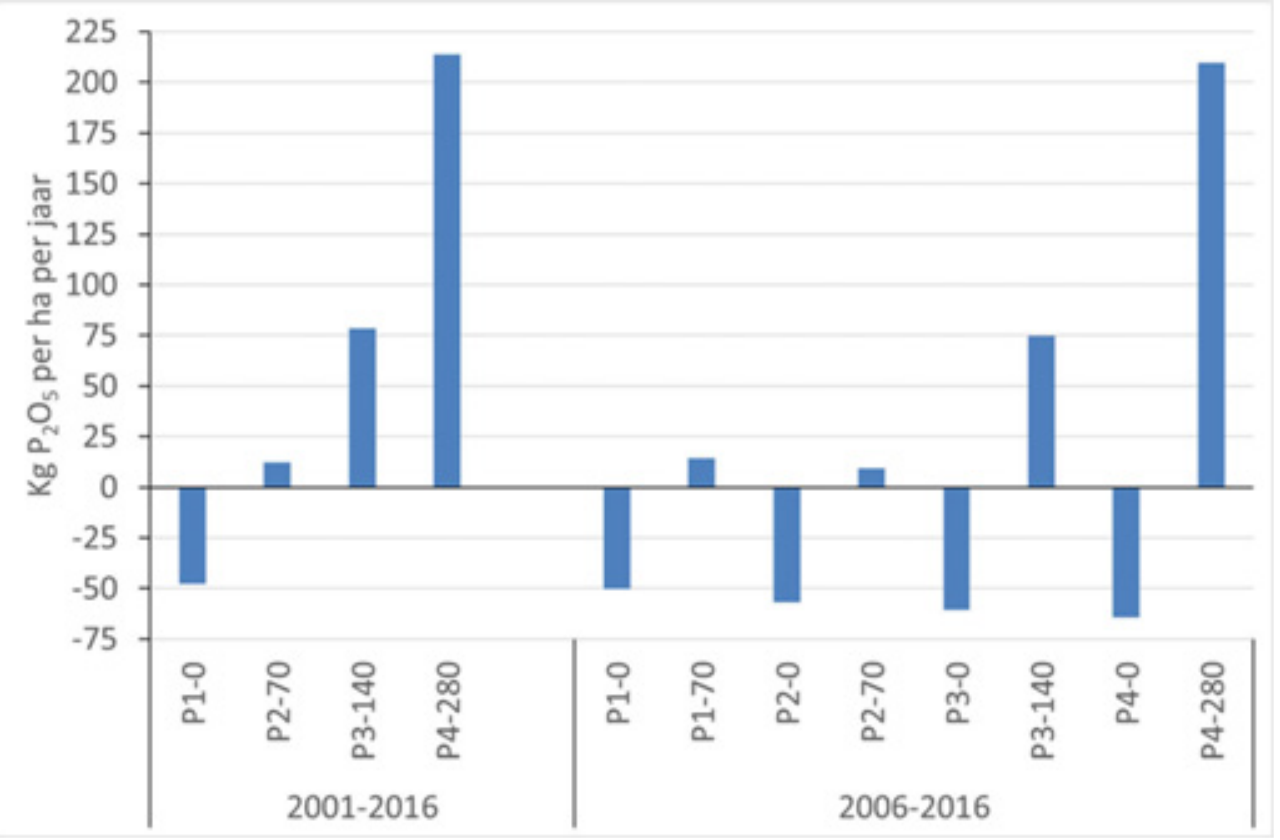

Figuur 4.2 Fosfaatoverschot in $\mathrm{kg} \mathrm{P}_{2} \mathrm{O}_{5} /$ ha/jaar bij de verschillende behandelingen gemiddeld over de perioden 2001-2016 en 2006-2016 (exclusief 2005).

\subsubsection{Marknesse (fosfaathoeveelhedenproef)}

Tabel 4.8 geeft de gemiddelde resultaten van de fosforgehalten van de hoofdproducten voor de behandelingen met standaardafwijking (s.e.) en aantal waarnemingen voor de periode 1990-2016. Door jarenlang eenzelfde fosfaatgift te geven, zijn verschillende fosfaattoestanden ontstaan: hoe hoger het fosfaatoverschot, hoe hoger de fosfaattoestand (zie 4.4). De combinatie van jaarlijkse 
fosfaatgift en door historische bemesting opgebouwde fosfaattoestand wordt teruggevonden in de fosforgehalten van de landbouwgewassen. Hoe hoger de jaarlijkse fosfaatgift (en daarmee de fosfaattoestand), hoe hoger het fosforgehalte is in het oogstproduct (knol, erwt, ui, biet, zaad). Verschillen tussen geen fosfaatbemesting en bemesting zijn meestal significant. Daarnaast is vanaf 1990 is het effect van strikte evenwichtsbemesting ( $M$ : aanvoer = afvoer) in onderzoek genomen op objecten met een vergelijkbare fosfaatstatus. Bij evenwichtsbemesting $(M)$ is het fosforgehalte veelal niet afwijkend van de behandeling zonder bemesting. Bij de behandelingen $2 \mathrm{M}$ en $3 \mathrm{M}$ worden weer (meestal significante) hogere gehalten vastgesteld.

Tabel 4.8 Gemiddelde fosforgehalten per gewas ( $\mathrm{g} P / \mathrm{kg}$ droge stof), gemeten vanaf 1990 bij de verschillende fosfaatgiften (exclusief 2005) met standaardafwijking (s.e.) en aantal jaren (n). M is evenwichtsbemesting, tussen haakjes wordt de gemiddelde afvoer over de jaren 1990-2016 gegeven (exclusief 2005).

\begin{tabular}{|c|c|c|c|c|c|c|c|c|c|}
\hline \multirow[t]{2}{*}{ Gewasgroep } & \multirow[t]{2}{*}{ Gewas } & \multirow[t]{2}{*}{ Parameter } & \multicolumn{7}{|l|}{ Gift } \\
\hline & & & 0 & 80 & 160 & 240 & $\begin{array}{l}M \\
(54)\end{array}$ & $\begin{array}{l}2 M \\
(108)\end{array}$ & $\begin{array}{l}3 M \\
(161)\end{array}$ \\
\hline \multirow{9}{*}{1} & \multirow{2}{*}{ Aardappel } & s.e. & 0,27 & 0,30 & 0,30 & 0,22 & 0,25 & 0,28 & 0,27 \\
\hline & & $\mathrm{n}$ & 40 & 20 & 20 & 20 & 20 & 20 & 20 \\
\hline & \multirow[t]{3}{*}{ Pootaardappel } & Gemiddelde & 1,44 & 1,53 & 1,55 & 1,61 & 1,44 & 1,48 & 1,61 \\
\hline & & s.e. & 0,20 & 0,22 & 0,18 & 0,18 & 0,20 & 0,18 & 0,16 \\
\hline & & $\mathrm{n}$ & 16 & 8 & 8 & 8 & 8 & 8 & 8 \\
\hline & Doperwt & $\mathrm{n}$ & 8 & 4 & 4 & 4 & 4 & 4 & 4 \\
\hline & \multirow[t]{3}{*}{ Ui } & Gemiddelde & 2,16 & 2,25 & 2,28 & 2,23 & 2,12 & 2,24 & 2,16 \\
\hline & & s.e. & 0,22 & 0,25 & 0,33 & 0,22 & 0,23 & 0,34 & 0,28 \\
\hline & & $\mathrm{n}$ & 16 & 8 & 8 & 8 & 8 & 8 & 8 \\
\hline \multirow[t]{3}{*}{2} & \multirow[t]{3}{*}{ Suikerbiet } & Gemiddelde & 1,11 & 1,37 & 1,42 & 1,49 & 1,24 & 1,31 & 1,35 \\
\hline & & s.e. & 0,23 & 0,16 & 0,14 & 0,18 & 0,17 & 0,17 & 0,17 \\
\hline & & $\mathrm{n}$ & 40 & 20 & 20 & 20 & 20 & 20 & 20 \\
\hline \multirow[t]{3}{*}{3} & \multirow[t]{3}{*}{ Zomergerst } & Gemiddelde & 4,02 & 4,06 & 4,17 & 4,24 & 4,06 & 4,10 & 4,12 \\
\hline & & s.e. & 0,41 & 0,40 & 0,42 & 0,41 & 0,44 & 0,47 & 0,36 \\
\hline & & $\mathrm{n}$ & 48 & 24 & 24 & 24 & 24 & 24 & 24 \\
\hline \multirow[t]{6}{*}{4} & \multirow[t]{3}{*}{ Wintertarwe } & Gemiddelde & 3,24 & 3,26 & 3,26 & 3,31 & 3,17 & 3,24 & 3,30 \\
\hline & & s.e. & 0,30 & 0,28 & 0,23 & 0,30 & 0,29 & 0,30 & 0,26 \\
\hline & & $\mathrm{n}$ & 16 & 8 & 8 & 8 & 8 & 8 & 8 \\
\hline & \multirow[t]{3}{*}{ Zomertarwe } & Gemiddelde & 4,02 & 4,13 & 4,16 & 4,28 & 4,04 & 4,04 & 4,04 \\
\hline & & s.e. & 0,54 & 0,54 & 0,49 & 0,53 & 0,53 & 0,59 & 0,42 \\
\hline & & $\mathrm{n}$ & 24 & 12 & 12 & 12 & 12 & 12 & 12 \\
\hline
\end{tabular}

In Tabel 4.9 wordt de gemiddelde fosfaatafvoer bij verschillende gewassen en verschillende fosfaatgiften gegeven. Bij de veldproef te Markenesse zijn de fosfaatafvoeren lager dan $60 \mathrm{~kg} \mathrm{P}_{2} \mathrm{O}_{5} / \mathrm{ha}_{\text {. }}$ Door fosfaat toe te dienen, neemt de fosfaatafvoer toe. De toename is het grootst bij suikerbiet. De verschillen tussen de behandelingen met fosfaatbemesting bedragen doorgaans enkele $\mathrm{kg}$ fosfaat. Bij suikerbiet bedraagt het verschil tussen behandeling met evenwichtsbemesting en de hoogste

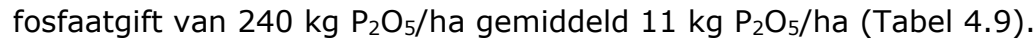


Tabel 4.9 Gemiddelde fosfaatafvoer ( $k g \mathrm{P}_{2} \mathrm{O}_{5} / \mathrm{ha}$ ), gemeten vanaf 1990 bij de verschillende fosfaatgiften (exclusief 2005) met standaardafwijking (s.e.) en aantal jaren ( $n$ ). M is evenwichtsbemesting, tussen haakjes wordt de gemiddelde afvoer over de jaren 1990-2016 gegeven (exclusief 2005).

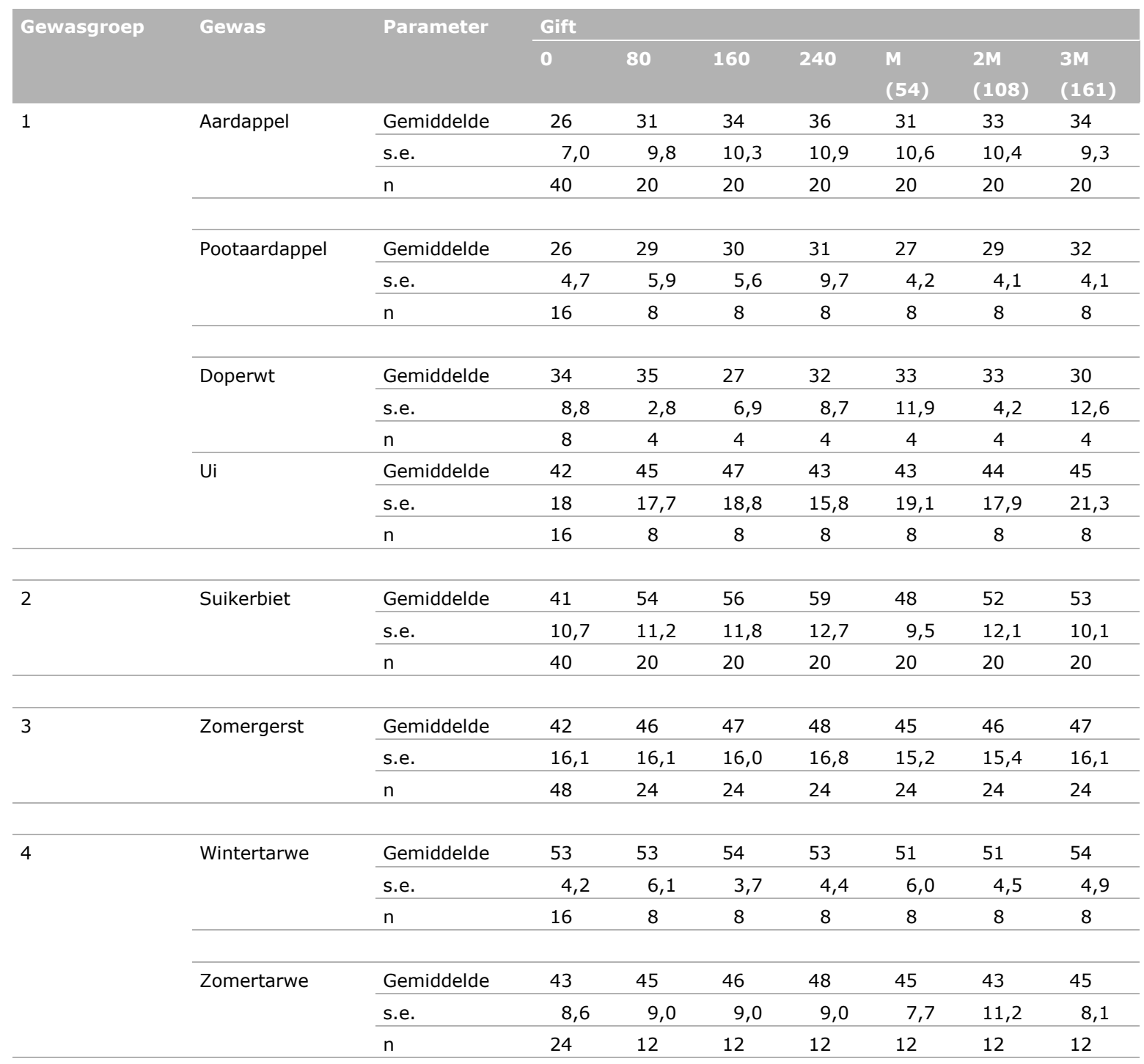

\subsubsection{Wijster (fosfaathoeveelhedenproef)}

De fosforgehalten van de hoofdproducten van de veeljarige veldproef te Wijster worden gegeven in Tabel 4.10. Bij deze veldproef werden door de tijd heen diverse wijzigingen in de proefopzet aangebracht. Die wijzigingen betroffen aanpassingen in de hoogte van de fosfaatgift. Een aantal fosfaatmeststoffen van thermische productiemethoden bleken niet meer beschikbaar, waardoor desbetreffende veldjes op nawerking werden gelegd (de gloeifosfaten Rhekaphos, Rhenania) of een andere fosfaatmeststof kregen (slakkenmeel, Thomasslakkenmeel). Tabel 4.10 vat gegevens samen van behandelingen die vanaf aanleg in 1972 ongewijzigd bleven in behandeling.

Net als bij de fosfaathoeveelhedenveldproef te Marknesse leidt veeljarige toepassing van verschillende fosfaatgiften tot een bereik in fosfaatoverschotten. De veldjes van de veldproef krijgen daardoor een bereik in fosfaattoestanden. Het effect van bemesting op het fosforgehalte is een resultante van de fosfaatgift en de opgebouwde fosfaattoestand.

In de regel neemt het fosforgehalte toe met de hoogte van de fosfaatgift. Dit effect is groter bij superfosfaat dan bij de fosfaatmeststoffen afkomstig van thermische productieprocessen. Het effect is bij natuurfosfaat doorgaans niet waarneembaar. Superfosfaat is een wateroplosbare meststof, de 
meststoffen van thermische productiemethoden zijn oplosbaar in organische zuren (citraten, complexerend), natuurfosfaat is ook oplosbaar in een sterker organisch zuur (mierenzuur). Een hogere oplosbaarheid van de fosfaatmeststoffen leidt in het algemeen tot een hoger fosforgehalte van het gewas. Een hoger fosforgehalte gaat vaak - maar niet altijd - samen met een hogere opbrengst. Zo hebben gewassen bemest met meststoffen op basis van slakkenmeel lagere fosforgehalten, maar hebben gelijke of hogere opbrengsten in vergelijking met superfosfaat. Deels wordt dit toegeschreven aan een $\mathrm{pH}$-effect, deels wordt dit toegeschreven aan luxeconsumptie van fosfaat.

In Tabel 4.11 wordt de gemiddelde fosfaatafvoer bij verschillende gewassen en verschillende fosfaatvormen en fosfaatgiften gegeven. Bij de veldproef te Wijster op zandgrond variëren de fosfaatafvoeren van 15 tot $74 \mathrm{~kg} \mathrm{P}_{2} \mathrm{O}_{5} / \mathrm{ha}$. Door fosfaat toe te dienen, neemt de fosfaatafvoer toe. De toename is het grootst bij suikerbiet. De verschillen tussen de behandelingen met fosfaatbemesting zijn groter dan die gevonden bij de zavels te Lelystad en Marknesse. Dit is een gevolg van de grotere reactie van het gewas op fosfaatbemesting en fosfaattoestand dat geconditioneerd wordt door de zeer lage fosfaattoestand van het niet met fosfaat bemeste veldje te Wijster. Fosfaatgiften van $90 \mathrm{~kg}$ $\mathrm{P}_{2} \mathrm{O}_{5} /$ ha of lager leiden tot een fosfaatafvoer die lager is dan $60 \mathrm{~kg} \mathrm{P}_{2} \mathrm{O}_{5} /$ ha (dit is de fosfaatgebruiksnorm bij fosfaatklasse neutraal). Bij snijmaïs is de fosfaatafvoer bij een gift van $90 \mathrm{~kg}$ $\mathrm{P}_{2} \mathrm{O}_{5} /$ ha gemiddeld $62 \mathrm{~kg} \mathrm{P}_{2} \mathrm{O}_{5} / \mathrm{ha}$ (Tabel 4.1). De variatie, vooral veroorzaakt door verschillen tussen proefjaren, is aanzienlijk (standaardafwijking tot $33 \mathrm{~kg} \mathrm{P}_{2} \mathrm{O}_{5} / \mathrm{ha}$ ). De hoge standaardafwijking bij snijmaïs wordt toegeschreven aan de verslechterende opbrengst door continuteelt.

\section{Conclusie fosfaatgehalten}

De veldproeven in Lelystad, Wijster en Marknesse wijzen uit dat het fosforgehalte in het geoogste gewas toeneemt met een toenemende fosfaattoestand en/of fosfaatdosering.

Het fosfaatgehalte is een resultante van zowel fosfaattoestand als fosfaatbemesting. De toename wordt gevonden bij een breed bereik van fosfaatdoseringen (tot $240 \mathrm{~kg} \mathrm{P}_{2} \mathrm{O}_{5} / \mathrm{ha}$ ) en hierbij is bij hoge bemestingen en hoge fosfaattoestanden vaak sprake van luxeconsumptie; i.e. het fosforgehalte neemt toe, terwijl de opbrengst niet verder toeneemt.

De gewasreactie bij dekzand op fosfaatbemesting is groter dan die op de zavelgronden. Dit wordt bij zandgrond veroorzaakt door de zeer lage fosfaattoestand van de sinds 1972 niet met fosfaat bemeste behandeling ${ }^{15}$. Op de zavel van Lelystad voeren suikerbiet, peen en wintertarwe bij een fosfaatgift van

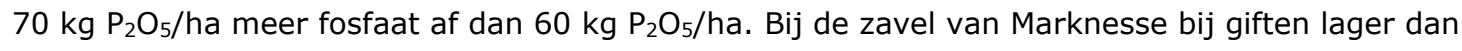
$90 \mathrm{~kg} \mathrm{P}_{2} \mathrm{O}_{5} / \mathrm{ha}$ is de afvoer lager dan $60 \mathrm{~kg} \mathrm{P}_{2} \mathrm{O}_{5} / \mathrm{ha}$. Dit wordt ook bij dekzand van Wijster gevonden bij een fosfaatgift van $90 \mathrm{~kg} \mathrm{P}_{2} \mathrm{O}_{5} / \mathrm{ha}$ : bij snijmaïs is de afvoer dan gemiddeld $62 \mathrm{~kg} \mathrm{P}_{2} \mathrm{O}_{5} / \mathrm{ha}$. Variatie in de fosfaatafvoer wordt vooral ingebracht door verschillen in opbrengst tussen proefjaren.

\footnotetext{
${ }^{15}$ Langdurig fosfaat onthouden heeft bij Wijster geleid tot een absoluut fosfaatgebrek.
} 


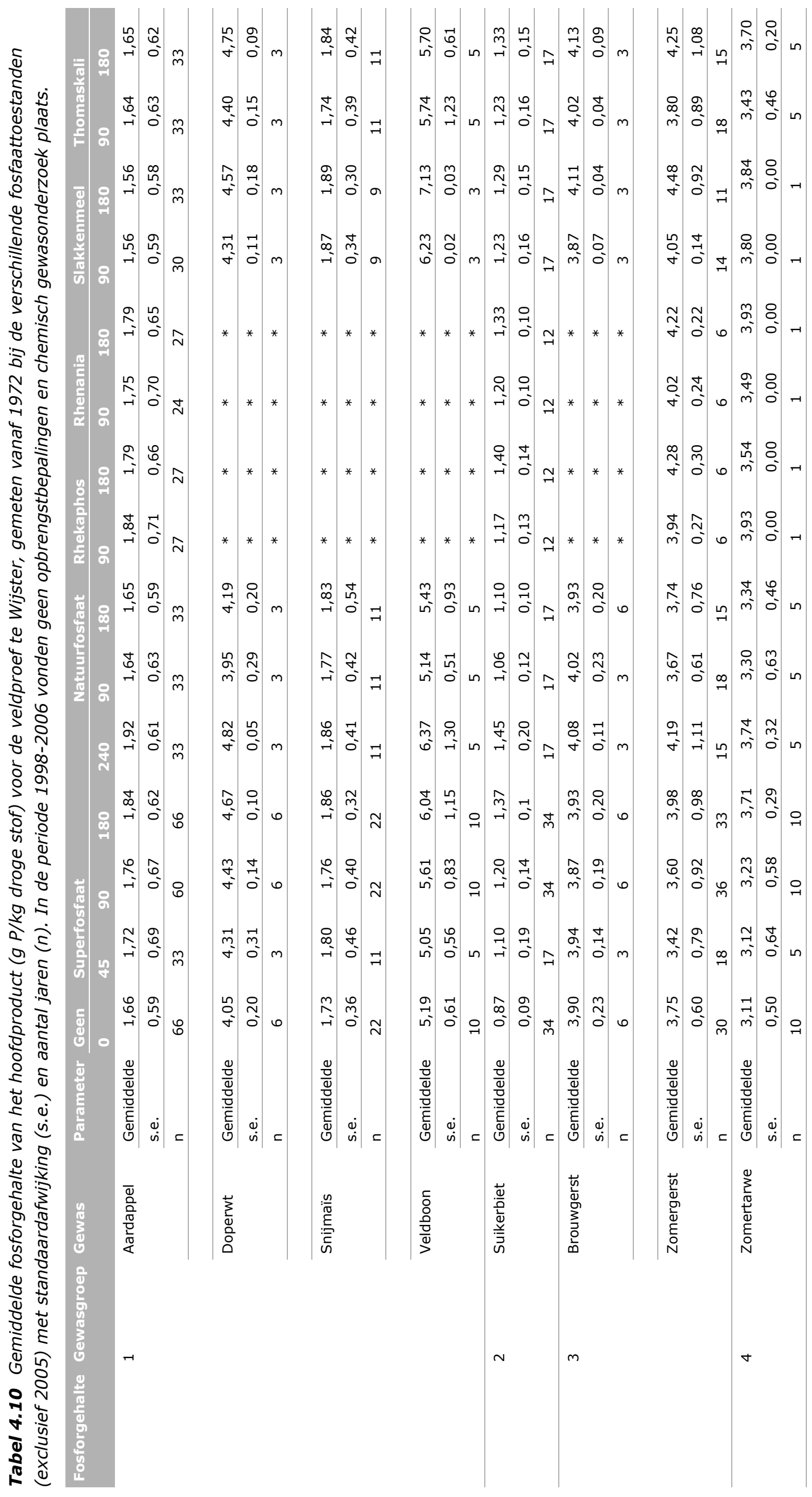




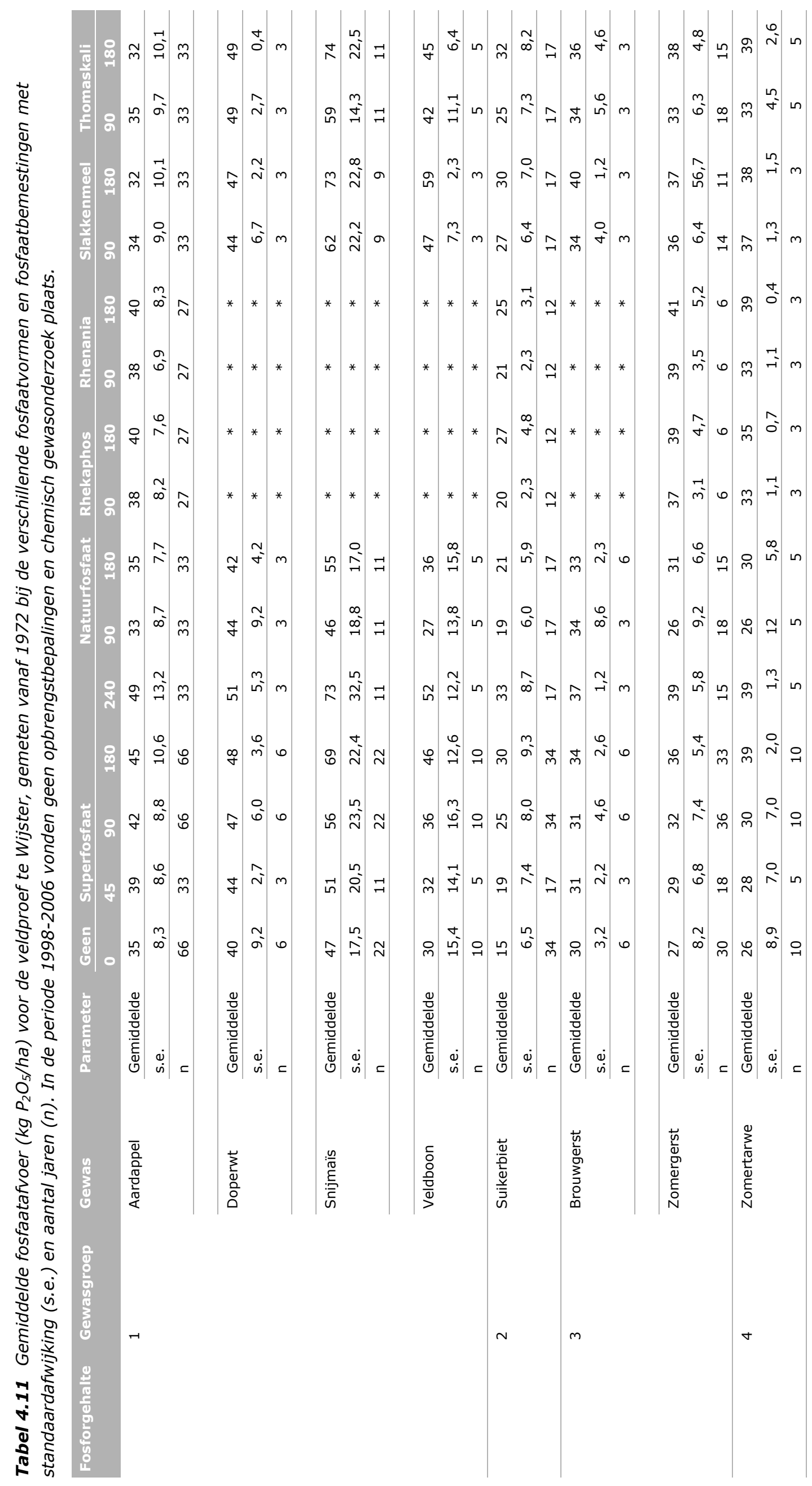




\subsection{Bodem}

\subsubsection{Standaardbodemtesten en effect van fosfaatbalans}

\subsubsection{Fosfaattoestandenproef Lelystad}

In Figuur 4.3 is het verloop van het jaarlijks gemeten Pw-getal in de bodemlaag 0-30 cm weergegeven van het fosfaattoestandenproefveld te Lelystad. Eind jaren tachtig waren reeds vier in fosfaattoestand verschillende objecten gecreëerd, wat tot uiting komt in verschillende aanvangsniveaus van het Pwgetal in 1990. De Pw-getallen laten tussen de jaren een sterke fluctuatie zien. Toch zijn er duidelijke verschillen tussen de P-toestanden. Bij P1-onbemest lijkt het Pw-getal iets te zijn gedaald in de loop der jaren, maar die daling is op basis van een lineaire trend niet significant. Het Pw-getal heeft zich bij $\mathrm{P} 1$ de laatste tien jaar gestabiliseerd rond $18 \mathrm{mg} \mathrm{P}_{2} \mathrm{O}_{5} / \mathrm{L}$ (gemiddelde van de jaarlijkse metingen in 2006-2016). Bij P2-, P3- en P4-bemest, waarbij wordt bemest met respectievelijk 70, 180 en 240 kg $\mathrm{P}_{2} \mathrm{O}_{5} /$ ha/jaar, is er sprake van een significante stijging van het Pw-getal in de loop van de tijd op basis van een lineaire trend. De mate van stijging is bij P4 significant groter dan bij P3 en bij P3 significant groter dan bij P2. Wanneer evenwel wordt gekeken naar de periode vanaf 2003, lijkt het Pw-getal zich te hebben gestabiliseerd. De laatste tien jaar schommelt het rond de 41 voor P2, rond de 67 voor P3 en rond de 113 voor P4 (gemiddelden in de periode 2006-2016). Het gemiddelde jaarlijkse overschot in deze periode bedroeg $-49 \mathrm{~kg} \mathrm{P} \mathrm{P}_{5}$ per ha bij P1, 11 bij P2, 76 bij P3 en 210 bij P4. In Figuur 4.4 is het gestabiliseerde Pw-getal uitgezet tegen het jaarlijkse fosfaatoverschot. Hieruit kan worden afgelezen dat de P-toestand zich bij jaarlijkse bemesting met $70 \mathrm{~kg} \mathrm{P}_{2} \mathrm{O}_{5}$ (P2) zou stabiliseren rond Pw-getal $42 \mathrm{mg} \mathrm{P}_{2} \mathrm{O}_{5} / \mathrm{L}$, waarbij het fosfaatoverschot gemiddeld $11 \mathrm{~kg} \mathrm{P}_{2} \mathrm{O}_{5} / \mathrm{ha} /$ jaar bedraagt.

Uitmijnen (vanaf 2005 geen fosfaatbemesting) had direct effect in de proef: het leidde tot een significante daling van het Pw-getal bij P2, P3 en P4 (Figuur 4.3). De jaarlijkse fosfaatbemesting à $70 \mathrm{~kg} \mathrm{P}_{2} \mathrm{O}_{5}$ per ha vanaf 2006 bij de lage toestand (P1) liet direct een stijging laat zien van het Pwgetal, echter het verschil met $\mathrm{P} 1$-onbemest $(\mathrm{P} 1-0)$ is nog niet significant. Bemesting van $\mathrm{P} 1$ jaarlijks met een jaarlijks gemiddeld overschot van $18 \mathrm{~kg} \mathrm{P}_{2} \mathrm{O}_{5} /$ ha heeft nog niet het niveau van $\mathrm{P} 2$ bereikt. Voortzetting van het onderzoek zal moeten uitwijzen hoeveel het Pw-getal bij P1-bemest verder toeneemt en op welk niveau het Pw-getal zich stabiliseert. 


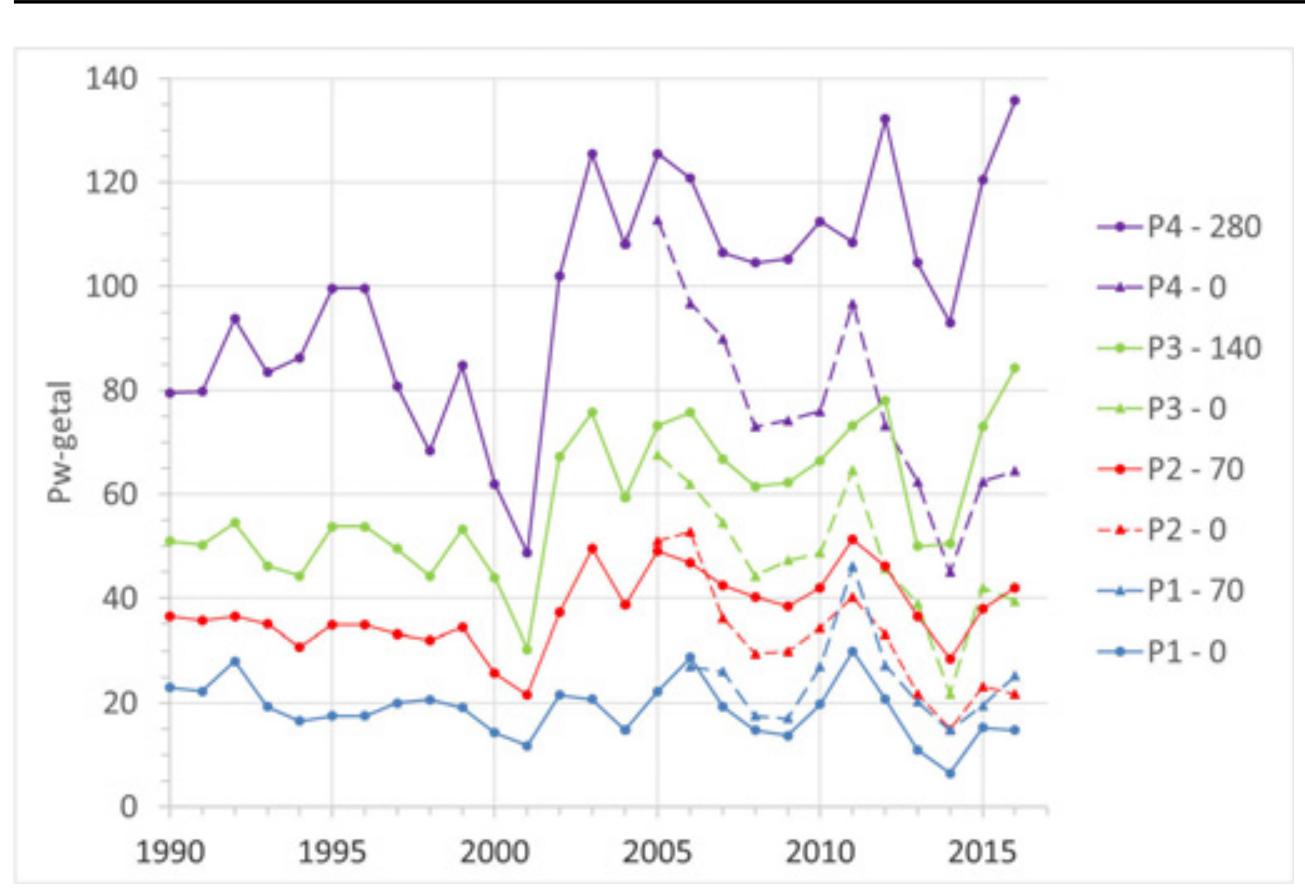

Figuur 4.3 Verloop van het $P w$-getal in $\mathrm{mg} \mathrm{P}_{2} \mathrm{O}_{5} / \mathrm{L}$ vanaf 1990 in de bodemlaag 0-30 cm bij de verschillende objecten op het fosfaattoestandenproefveld te Lelystad. Vanaf 2002 werden veldjes opgesplitst naar een bemest deel (70, 140 en $280 \mathrm{~kg} \mathrm{P}_{2} \mathrm{O}_{5} / \mathrm{ha}$ ) en een onbemest deel. De behandeling $\mathrm{P} 1$ werd opgesplitst naar een onbemest deel en een bemest deel ( $70 \mathrm{~kg} \mathrm{P}_{2} \mathrm{O}_{5} / \mathrm{ha}$ ). Waarom tussen 2001 en 2002 een sprong optreedt, is onduidelijk.

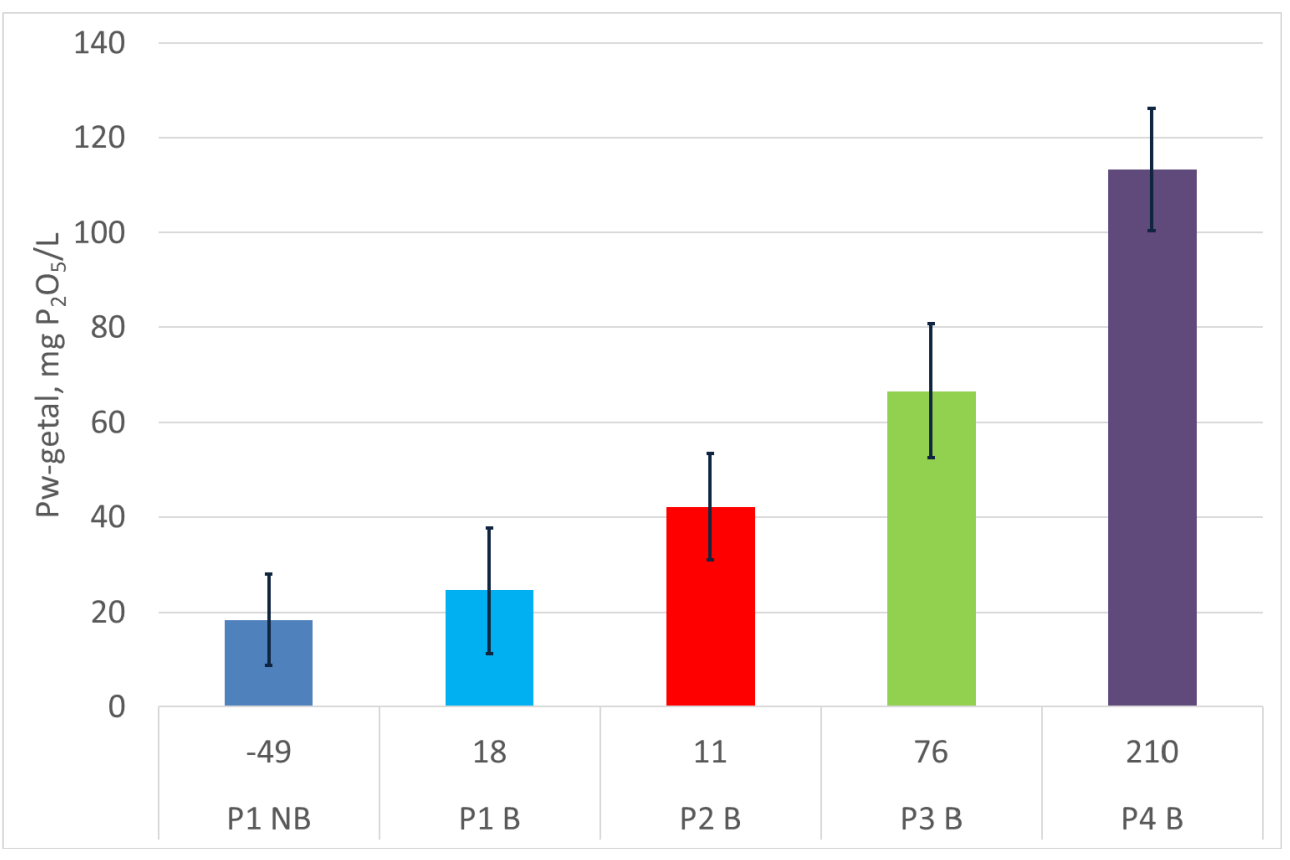

Figuur 4.4 Gestabiliseerd $P w$-getal in $\mathrm{mg} \mathrm{P}_{2} \mathrm{O}_{5} / \mathrm{L}$ in de bodemlaag 0-30 cm bij de verschillende fosfaattoestanden (P1, P2, P3 en P4) met bemesting (B) op het fosfaattoestandenproefveld te Lelystad, uitgezet tegen het gemiddelde jaarlijkse fosfaatoverschot in $\mathrm{kg} \mathrm{P}_{2} \mathrm{O}_{5} / \mathrm{ha} / \mathrm{jaar}$. Gestabiliseerd in deze context is Pw-getal dat over verschillende jaren ongewijzigd blijft, temporele variatie daargelaten. Daarnaast wordt het niet gestabiliseerde Pw-getal bij een jaarlijkse fosfaatgift van $70 \mathrm{~kg}$ $\mathrm{P}_{2} \mathrm{O}_{5} /$ ha gegeven, leidend tot een jaarlijks overschot van $18 \mathrm{~kg} \mathrm{P}_{2} \mathrm{O}_{5} /$ ha. Het Pw-getal neemt hier jaarlijks nog wat toe.

Door jaren achtereen meer fosfaat of minder fosfaat toe te dienen, ontstaan jaarlijks verschillen in fosfaatoverschotten per behandeling. Die jaarlijkse overschotten leiden tot accumulatie in de bodem. De cumulatieve fosfaatoverschotten zijn berekend. Deze cumulatieve fosfaatoverschotten zijn negatief 
als het gewas meer fosfaat afvoert dan wordt aangevoerd en zijn positief als de fosfaatbemesting hoger is dan de gewasafvoer.

In Figuur 4.5 is het Pw-getal in de bouwvoor uitgezet tegen het cumulatieve fosfaatoverschot per P-toestand. Dit betreft het jaarlijkse, gesommeerde overschot dat is opgebouwd vanaf 1990. Het betreft de objecten P1-onbemest en P2-, P3- en P4-bemest. Ondanks de jaarlijkse fluctuaties in Pwmeting komt duidelijk het beeld naar voren dat het Pw-getal stijgt naarmate het cumulatieve fosfaatoverschot toeneemt en dat het Pw-getal daalt bij een fosfaattekort op de balans. Vanaf 2003 blijkt een toename van het fosfaatoverschot niet/nauwelijks meer tot uitdrukking te komen in een stijging van het Pw-getal (Figuur 4.3). Het jaarlijkse fosfaatoverschot is dan kennelijk nodig op het Pw-getal op het ingestelde niveau te handhaven. Het fosfaat accumuleert wel in de bodem, maar leidt dus niet meer tot een stijging van het Pw-getal. Hierin wordt een aanwijzing gevonden dat er sprake is van een herverdeling van residuair meststoffosfaat over verschillende bodemfracties die niet volledig of niet in het Pw-getal tot uitdrukking komen.

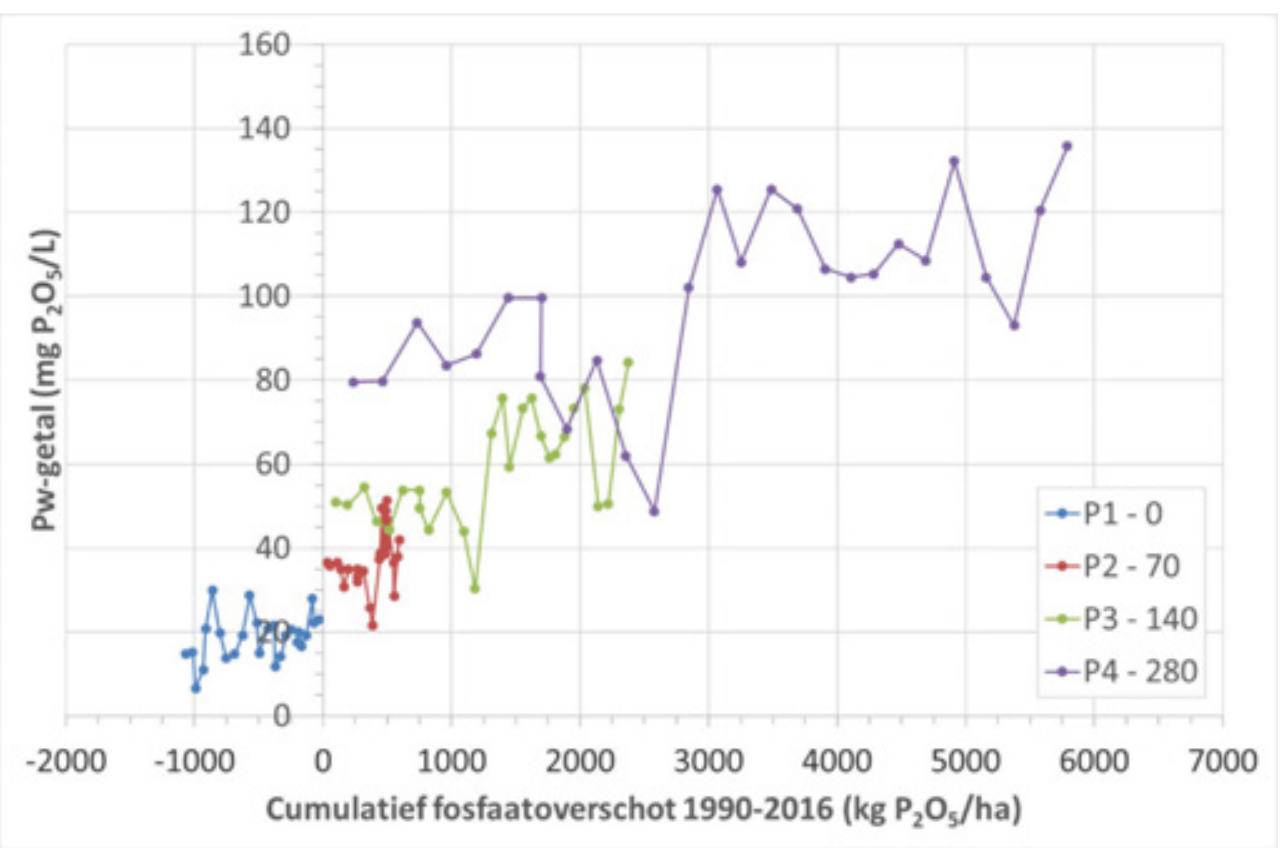

Figuur 4.5 $\mathrm{Pw}$-getal in $\mathrm{mg} \mathrm{P}_{2} \mathrm{O}_{5} / \mathrm{L}$ uitgezet tegen het cumulatieve fosfaatoverschot bij de verschillende $P$-toestanden van het fosfaattoestandenproefveld te Lelystad.

\subsubsection{Fosfaathoeveelheden veldproef te Marknesse}

De veldproef werd in 1972 aangelegd. Vanaf die tijd werd jaarlijks een constante bemestingsgift met

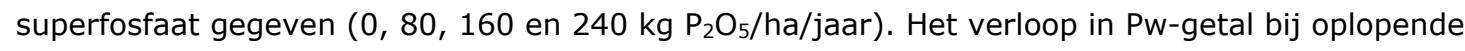
bemesting is weergegeven in Figuur 4.6. Een hogere fosfaatgift leidt tot een hogere fosfaattoestand. Het achterwege laten van bemesting leidt niet tot een daling van de fosfaattoestand. De bodem

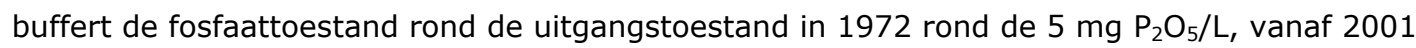
schommelt het $\mathrm{Pw}$-getal rond de $15 \mathrm{mg} \mathrm{P}_{2} \mathrm{O}_{5} / \mathrm{L}$. Die wijziging in niveau valt samen met een wijziging in bedrijfsvoering, in gewasrotatie en wijziging in het uitvoerend laboratorium. Gegevens van het P-Algetal en $\mathrm{P}-\mathrm{CaCl}_{2}$ zijn niet vanaf 1972 beschikbaar. Met terugwerkende kracht worden - waar mogelijk - gearchiveerde grondmonsters alsnog op deze parameters geanalyseerd. Dit onderdeel zal in de komende jaren stapsgewijs worden uitgevoerd. Vooralsnog kan een trendanalyse vanaf 1972 niet betrokken worden bij deze synthese.

Behandelingen met 80, 160 en $240 \mathrm{~kg} \mathrm{P}_{2} \mathrm{O}_{5} / \mathrm{ha} / \mathrm{jaar}$ leidden de eerste tien jaar tot een relatief snelle stijging van de fosfaattoestand. In de jaren tachtig en negentig is er sprake van een meer geleidelijke

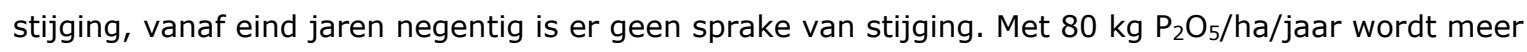
fosfaat aangevoerd dan afgevoerd. Het gemiddelde jaarlijkse overschot is bij deze behandeling $22 \mathrm{~kg} \mathrm{P}_{2} \mathrm{O}_{5} / \mathrm{ha} / \mathrm{jaar}$. Dit overschot - uitgaande van een lage fosfaattoestand - is niet voldoende om 
een P-toestand naar de klasse neutraal te brengen. Er is sprake van grote variatie tussen jaren, soms met forse dalingen die niet aan behandelingen gerelateerd zijn (1998, 2010, 2013). Bij aanvang van het onderzoek naar evenwichtsbemesting in 1990 was de fosfaattoestand van de veldjes met deze behandeling gelijk aan die van de niet met fosfaat bemeste veldjes. Dit bleef gedurende de looptijd tot en 2016 ongewijzigd.

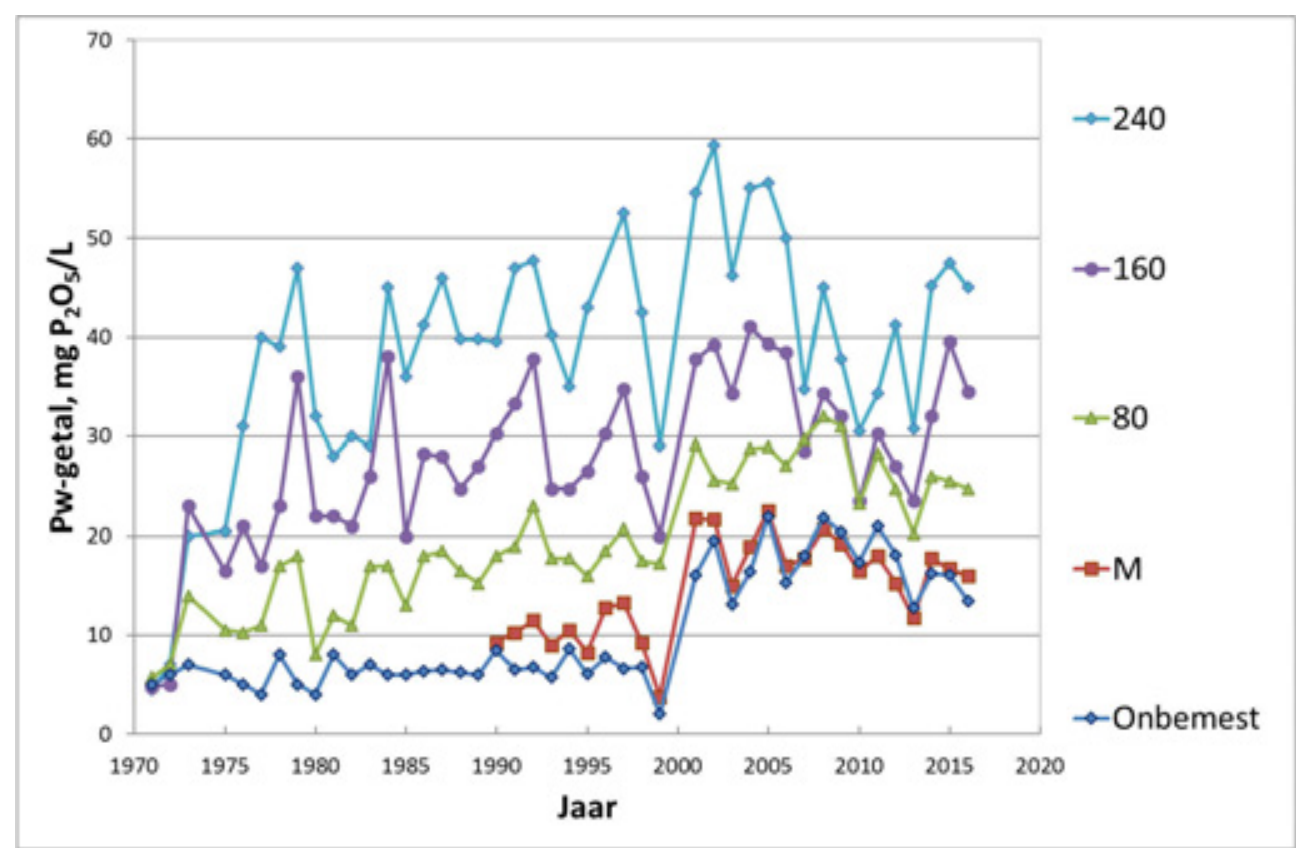

Figuur 4.6 Verloop van het Pw-getal vanaf 1990 in de bodemlaag 0-25 cm bij de verschillende fosfaatgiften op de fosfaathoeveelhedenveldproef te Marknesse. Vanaf 1990 zijn behandelingen aangelegd met strikte evenwichtsbemesting (M).

In de periode 1972-2016 zijn grote verschillen in fosfaatoverschotten ontstaan: -2177 tot $+8024 \mathrm{~kg}$ $\mathrm{P}_{2} \mathrm{O}_{5} /$ ha door fosfaatbemesting te onthouden of sterk verhoogd te geven ( $240 \mathrm{~kg} \mathrm{P}_{2} \mathrm{O}_{5} / \mathrm{ha}$ ). Het cumulatieve fosfaatoverschot bij strikte ${ }^{16}$ evenwichtsbemesting is $0 \mathrm{~kg} \mathrm{P}_{2} \mathrm{O}_{5} /$ ha (Figuur 4.6). Het effect van het overschot blijkt afhankelijk te zijn van de hoogte van dat overschot en de tijdsduur van het overschot. Eenzelfde overschot veroorzaakt door jaarlijks $160 \mathrm{~kg} \mathrm{P}_{2} \mathrm{O}_{5} /$ ha te geven, leidt tot een lagere waarde voor het $\mathrm{Pw}$-getal dan een identiek overschot gegeven met $240 \mathrm{~kg} \mathrm{P}_{2} \mathrm{O}_{5}$ (Figuur 4.7). De tijdsduur van het fosfaatoverschot blijkt bij de bodem van Marknesse invloed uit te oefenen op de mate van verhoging van het Pw-getal. Dit effect manifesteert zich bij cumulatieve

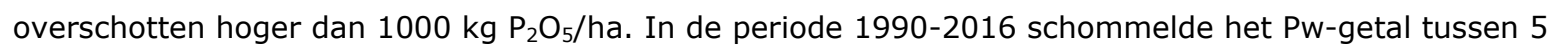
en $23 \mathrm{mg} \mathrm{P}_{2} \mathrm{O}_{5} / \mathrm{L}$ bij strikte evenwichtsbemesting (cumulatief overschot $0 \mathrm{~kg} \mathrm{P}_{2} \mathrm{O}_{5} / \mathrm{ha}$ ).

\footnotetext{
${ }^{16}$ Gedurende de periode 1990-2016 zijn er jaren geweest dat de jaarlijkse balans niet op 0 uitkwam als gevolg van het ontbreken van gegevens van de fosfaatafvoer (volggewas volgde te snel de voorvrucht op) of een incidentele bemestingsfout. In 2016 waren alle vastgestelde afwijkingen bij evenwichtsbemesting gecorrigeerd.
} 


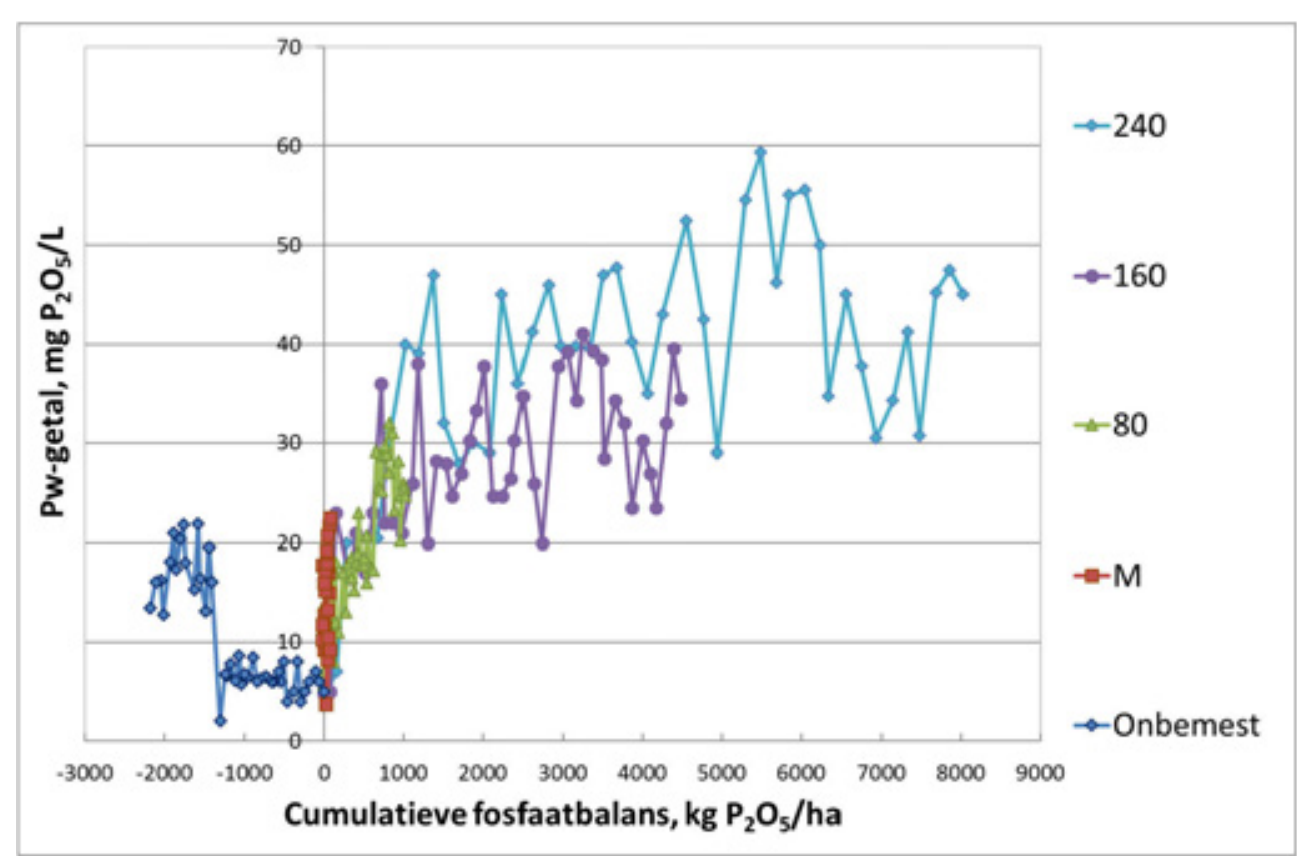

Figuur 4.7 $P$ w-getal in $\mathrm{mg} \mathrm{P}_{2} \mathrm{O}_{5} / \mathrm{L}$ uitgezet tegen het cumulatieve fosfaatoverschot bij fosfaatgiften 0, 80, 160 en $240 \mathrm{~kg} \mathrm{P}_{2} \mathrm{O}_{5} / \mathrm{ha} / \mathrm{jaar}$ en evenwichtsbemesting (M) voor de periode 1990-2016 voor Marknesse.

Vanaf 2000 zijn de fosfaattoestanden van de verschillende behandelingen ruwweg constant. In de periode 2000-2016 varieerden de fosfaatoverschotten, afhankelijk van gewas en objecten die afgestemd waren op evenwichtsbemesting (M, 2M, 3M). De jaarlijkse gemiddelde fosfaatoverschotten variëren in de periode 2000-2016 van -51 tot $+183 \mathrm{~kg} \mathrm{P}_{2} \mathrm{O}_{5} / \mathrm{ha}$. Indien deze jaarlijkse fosfaatoverschotten uitgezet worden tegen het Pw-getal gemiddeld over deze periode, dan leidt een fosfaatgift afgestemd op strikte evenwichtsbemesting tot een Pw-getal van 22 mg $\mathrm{P}_{2} \mathrm{O}_{5} / \mathrm{L}$ (Figuur 4.8).

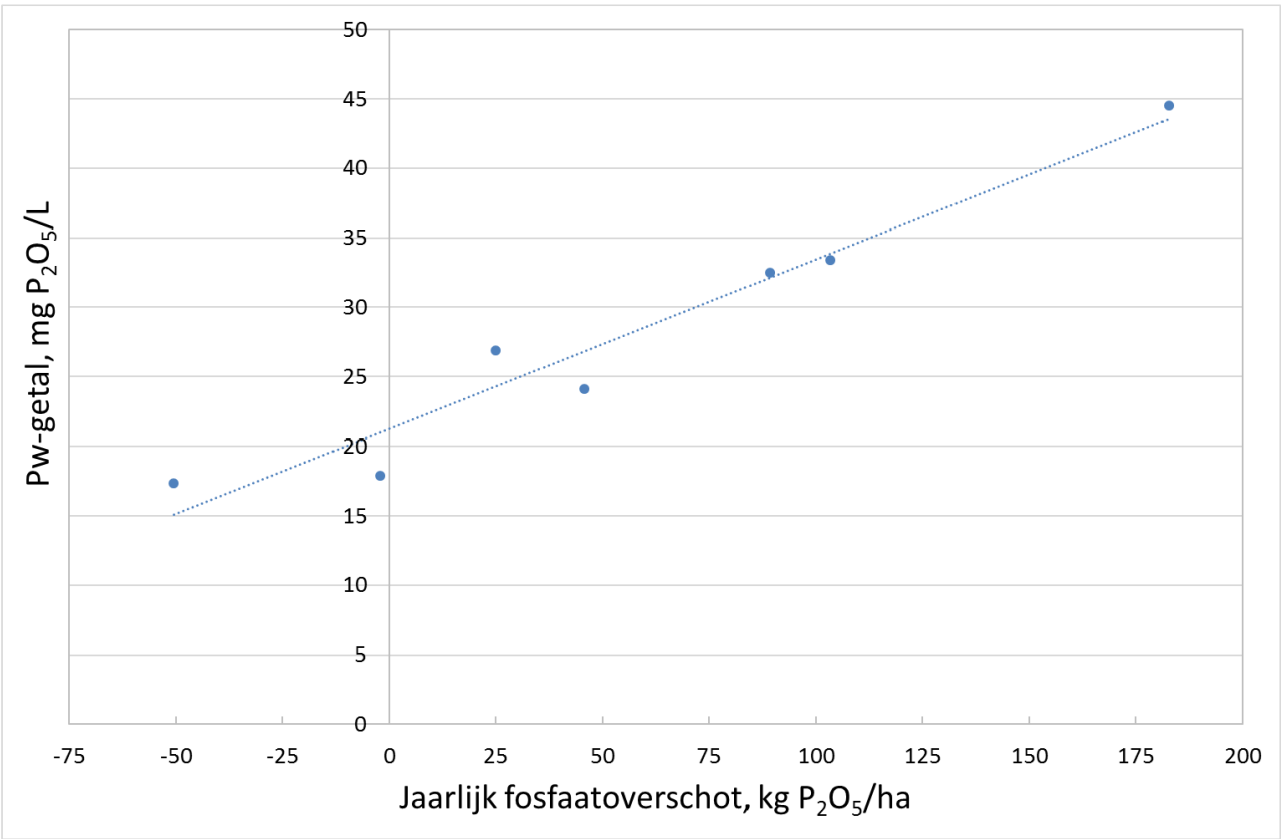

Figuur 4.8 Het $\mathrm{Pw}$-getal in $\mathrm{mg}_{2} \mathrm{O}_{5} / \mathrm{L}$ in de bodemlaag 0-25 cm (gemiddeld over 1990-2016) voor de fosfaathoeveelhedenveldproef te Marknesse als functie van het jaarlijkse fosfaatoverschot gemiddeld over de jaren 1990-2016. 


\subsubsection{Fosfaatvormen en hoeveelheden veldproef te Wijster}

De veldproef werd in 1972 aangelegd. Vanaf die tijd werd jaarlijks een constante bemestingsgift met superfosfaat gegeven $\left(0,45,90,180\right.$ en $\left.240 \mathrm{~kg} \mathrm{P}_{2} \mathrm{O}_{5} / \mathrm{ha} / \mathrm{jaar}\right)$. Daarnaast waren er behandelingen aanwezig met fosfaatmeststoffen van thermische productieprocessen (gloeifosfaat (Rhekaphos, Rhenania, Slakkenmeel en Thomasslakkenmeel) in giften van 90 en $180 \mathrm{~kg} \mathrm{P} \mathrm{P}_{2} \mathrm{O}_{5} / \mathrm{ha} / \mathrm{jaar}$. Tevens werd het tijdstip van bemesting als factor opgelegd (herfst, winter). De behandelingen met Rhenaniafosfaat werden in 1986 stilgelegd wegens het beëindigen van de productie van deze meststof, waarna de velden op nawerking werden gelegd. Vanaf 2012 werden de veldjes met behandelingen met Slakkenmeel beëindigd en worden effecten van 60 of $75 \mathrm{~kg} \mathrm{P}_{2} \mathrm{O}_{5} / \mathrm{ha} / \mathrm{jaar}$ als superfosfaat onderzocht. In de periode 1996-2001 werd geen grondonderzoek uitgevoerd. Het beloop van de fosfaattoestand (Pwgetal) vanaf 1972 wordt gegeven in Figuur 4.9.

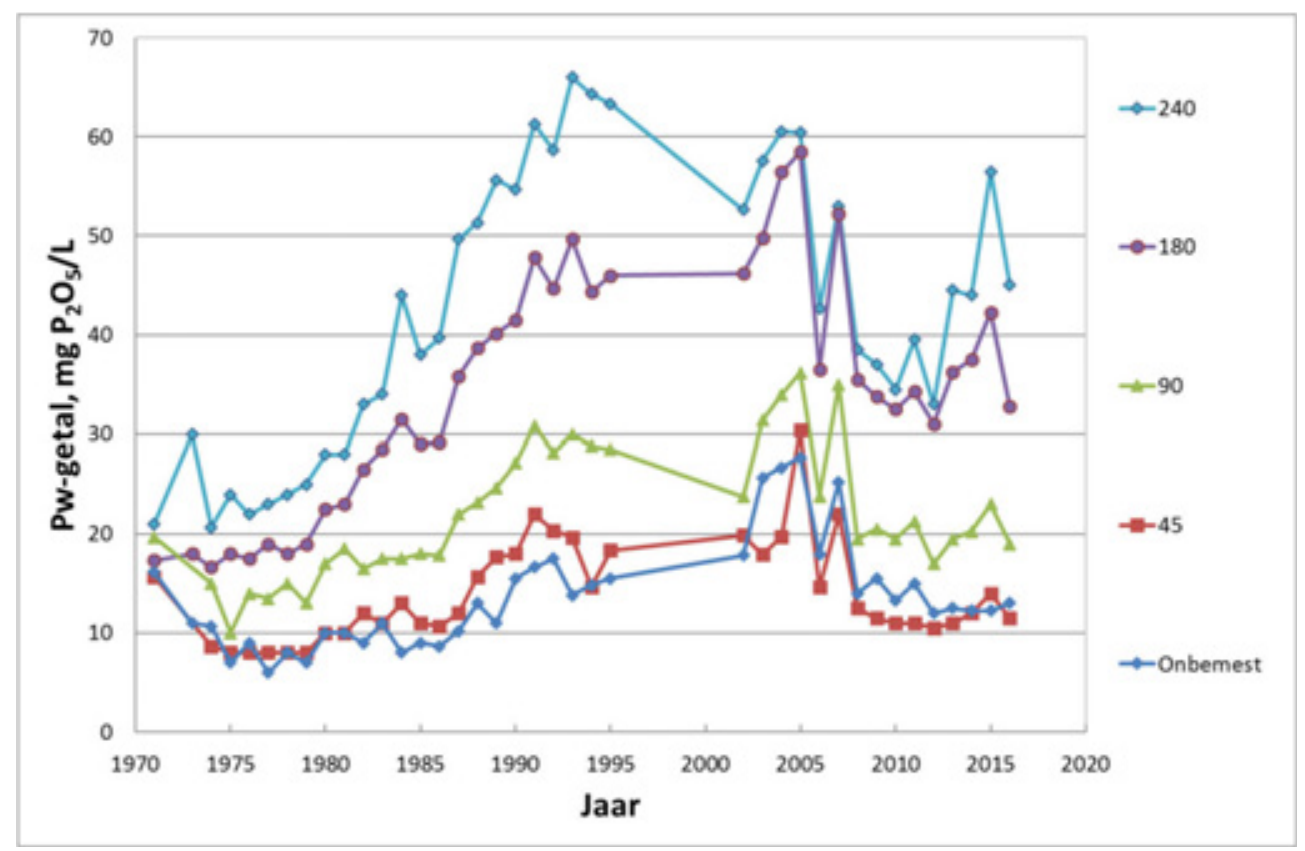

Figuur 4.9 Verloop van het $P w$-getal in $m g P_{2} O_{5} / L$ vanaf 1972 in de bodemlaag $0-25 \mathrm{~cm}$ bij de verschillende fosfaatgiften als superfosfaat op de fosfaatvormen - hoeveelheden veldproef te Wijster. In de periode 1996-2001 werd geen grondonderzoek uitgevoerd.

Vanaf 1972 tot begin jaren 90 (een periode van zo'n 20 jaar) leidden fosfaatoverschotten tot stijging van de fosfaattoestanden. In deze periode kwam de gift van $45 \mathrm{~kg}$ fosfaat/ha overeen met de gemiddelde fosfaatafvoer van het toenmalige bouwplan. Vanaf halverwege de jaren negentig treedt stabilisatie op, hoewel er sprake is van een grote jaar-tot-jaar-variatie. In de periode 2005-2010 trad een daling op die samenviel met een intensiever bouwplan zonder dat daardoor wezenlijke verschillen in de jaarlijkse afvoer van fosfaat optraden in vergelijking met daaraan voorafgaande jaren. Giften van 0, 45 en 90 blijkend vanaf 2008 qua beloop in Pw-getal stabiel te zijn; bij hogere giften is er sprake van een toename van de fosfaattoestand. Eenzelfde trend wordt vastgesteld voor $\mathrm{P}-\mathrm{CaCl}_{2}$ (beschikbaar vanaf 2008, data niet gegeven) en voor het P-Al-getal (data niet gegeven). Bij het P-Al-getal blijkt bij een gift van $90 \mathrm{~kg} \mathrm{P}_{2} \mathrm{O}_{5} / \mathrm{ha} /$ jaar ook sprake te zijn van lichte stijging.

De fosfaattoestand bij het onthouden van fosfaatbemesting over de periode 1972-2016 loopt vrij synchroon met de fosfaattoestand bij de behandeling met $45 \mathrm{~kg} \mathrm{P}_{2} \mathrm{O}_{5} / \mathrm{ha} / \mathrm{jaar}$. De orde van grootte is vrijwel identiek. $\mathrm{Er}$ is in deze periode geen grote daling in de fosfaattoestand bij geen fosfaatbemesting vastgesteld. De bodem blijkt fosfaat na te leveren. 


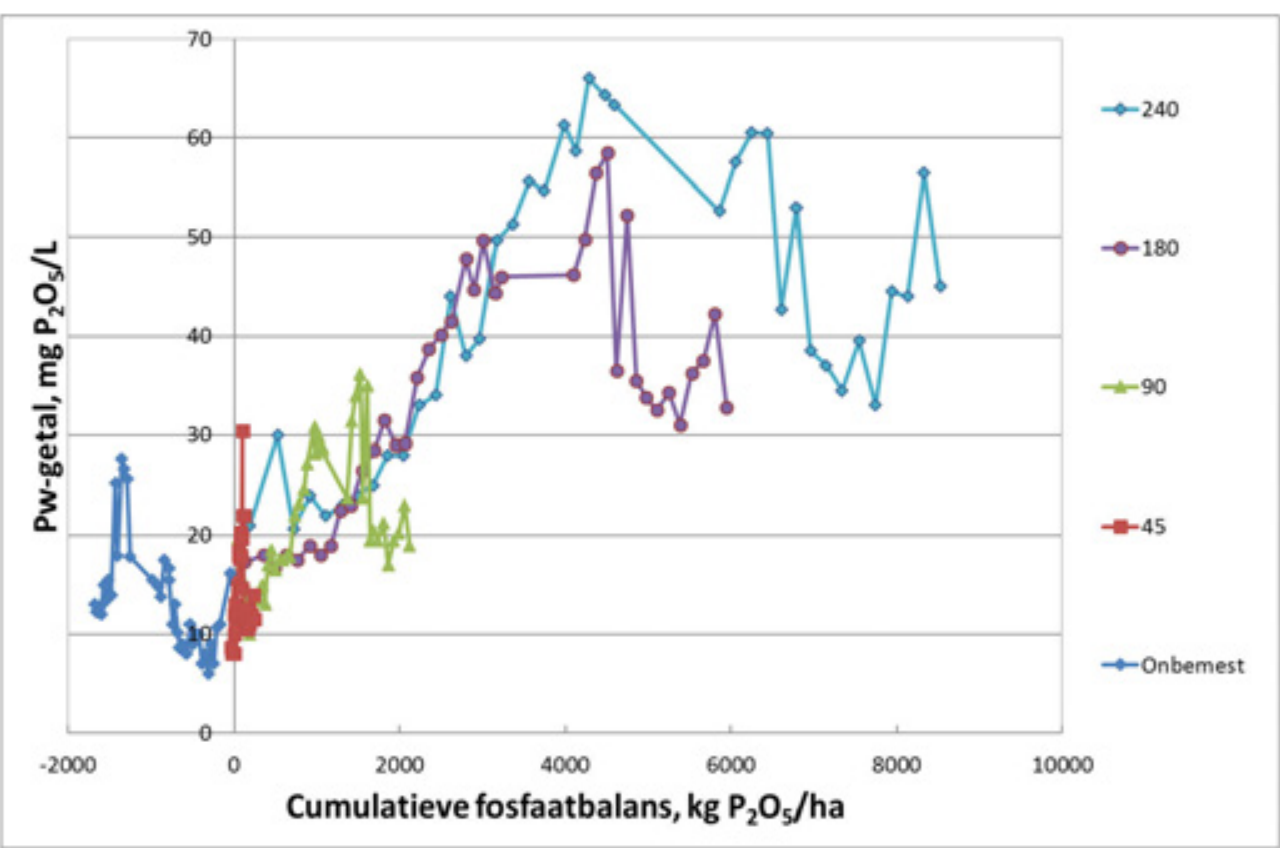

Figuur 4.10 $\mathrm{Pw}$-getal in $\mathrm{mg} \mathrm{P}_{2} \mathrm{O}_{5} / \mathrm{L}$ uitgezet tegen het geschatte ${ }^{17}$ Cumulatieve fosfaatoverschot bij fosfaatgiften 0, 45, 90, 180 en $240 \mathrm{~kg} \mathrm{P}_{2} \mathrm{O}_{5} / \mathrm{ha} / \mathrm{jaar}$ als superfosfaat voor de periode 1972-2016 voor Wijster.

Het effect van de accumulatie van fosfaat in de bodem op het Pw-getal wordt gegeven in Figuur 4.10. Hoe hoger het cumulatieve fosfaatoverschot (cumulatieve fosfaatbalans), hoe hoger de waarde van de fosfaattoestand is. De mate van verhoging van de fosfaattoestand (Pw-getal) neemt af bij toename van het cumulatieve overschot. Deze afname is echter verstrengeld met de generieke afname die vanaf 2005 plaatsvond. In de opbouwfase van de fosfaattoestand wordt minder variatie vastgesteld. Bij het bereiken van een meer stationaire fase in de fosfaattoestanden wordt een grotere variatie gevonden en is er sprake van een daling van de fosfaattoestand bij toename van het fosfaatoverschot. De toename in variatie valt onder andere ${ }^{18}$ samen door overgang naar een intensiever en variabel bouwplan (hoofdaandeel snijmaïs). Door standaardisatie in het bouwplan (meer granen) blijkt de fosfaattoestand weer toe te nemen bij hogere fosfaatgiften. Een verklaring die bij hoge fosfaatoverschotten aangegeven kan worden, is dat de bodem van de bodemlaag $0-25 \mathrm{~cm}$ meer fosfaat is gaan lekken, maar dit is niet waarschijnlijk (paragraaf 4.3.2). De daling wordt namelijk ook vastgesteld bij de gift van $90 \mathrm{~kg} \mathrm{P}_{2} \mathrm{O}_{5} / \mathrm{ha}_{\text {, }}$ hetgeen een effect van het lekken van fosfaat echter niet ondersteunt.

Figuren 4.9 en 4.10 wijzen op een grote dynamiek in het beloop van het Pw-getal in de tijd als functie van de fosfaatgift of als functie van de cumulatieve fosfaatbalans. Fosfaatgiften 0, 45 en $90 \mathrm{~kg} \mathrm{P}_{2} \mathrm{O}_{5} / \mathrm{ha} / \mathrm{jaar}$ geven een indicatie voor evenwicht in de fosfaattoestand, hogere giften blijken tot een toename van de fosfaattoestand te leiden. Een jaarlijks overschot leidt tot een toename van de fosfaattoestand. De toename is naast de hoogte van het fosfaatoverschot afhankelijk van de fosfaatvorm (Figuur 4.11). Op de zwak zure zandgrond te Wijster verhoogt de basische meststof Thomasslakkenmeel effectiever de fosfaattoestand dan superfosfaat. Dit is mede een gevolg van de aanvoer van zuur neutraliserende

\footnotetext{
17 In de periode 1998-2001 werd de proef in slapende vorm voortgezet, d.w.z. dat de behandelingen werden gecontinueerd, maar er werden geen metingen aan gewas en bodem uitgevoerd. Afvoer van fosfaat werd voor deze jaren geschat (zie 2.2.5.2).

$18 \mathrm{Er}$ zijn meerdere bronnen voor variatie te geven. Wat bijdraagt aan de variatie is overgang van een constant bouwplan met zetmeelaardappel $(2 \mathrm{x})$, suikerbiet $(1 \mathrm{x})$ en zomergraan $(1 \mathrm{x})$. De grondbewerkingen zijn daardoor binnen een bouwplan over een groot aantal jaren constant geweest. Het bouwplan werd verlaten door meer en veelal opvolgend snijmaïs te gaan telen. Continuteelt van snijmaïs deed de opbrengsten in opeenvolgende jaren dalen. Snijmaïs is daarop uit het bouwplan van de proefveldhouder gehaald en vervangen door veldboon, zomer- en wintergranen. Ondiep wortelende gewassen zijn vervangen door diep wortelende gewassen. Variatie kan mogelijk ingebracht zijn door bijdragen aan de fosfaattoestand van de bouwvoor door dieper gelegen bodemlagen. Ook wijzigingen in de uitvoering van de meting van het Pw-getal, P-Al-getal en $\mathrm{P}-\mathrm{CaCl}_{2}$ door meer zorg voor verwijdering van deeltjes fosfaat uit extractievloeistof kan bijdragen aan een verlaging van de meetwaarde. Die verwijdering is een gevolg van de eisen van huidige meetinstrumenten. Een kwantificering van de orde van grootte van de verschillende variantiebronnen behoort niet tot de uitvoering van dit syntheserapport en is overigens niet eenvoudig uit te voeren.
} 
waarde. Natuurfosfaat verhoogt de fosfaattoestand minder dan superfosfaat. Zonder bemesting blijft de fosfaattoestand op het beginniveau. Figuur 4.11 geeft een aanwijzing dat bij strikte evenwichtsbemesting de fosfaattoestand $\mathrm{P}-\mathrm{CaCl}_{2}$, het $\mathrm{Pw}$-getal en het P-Al-getal zich instellen op respectievelijk 0,2 mg P/kg, $12 \mathrm{mg} \mathrm{P}_{2} \mathrm{O}_{5} / \mathrm{L}$ en $32 \mathrm{mg} \mathrm{P}_{2} \mathrm{O}_{5} / 100 \mathrm{~g}$. Dit resultaat wordt bepaald door de uitgangstoestand. Er dient een ruime voorraad fosfaat in de bodem aanwezig te zijn om de intensiteitsparameters $\mathrm{P}-\mathrm{CaCl}_{2}$ en het $\mathrm{Pw}$ getal op hogere waarden te stellen, er is dan een ruimer overschot nodig Die ruimere overschotten zijn niet nodig bij de capaciteitsparameter P-Al-getal (Figuur 4.11).
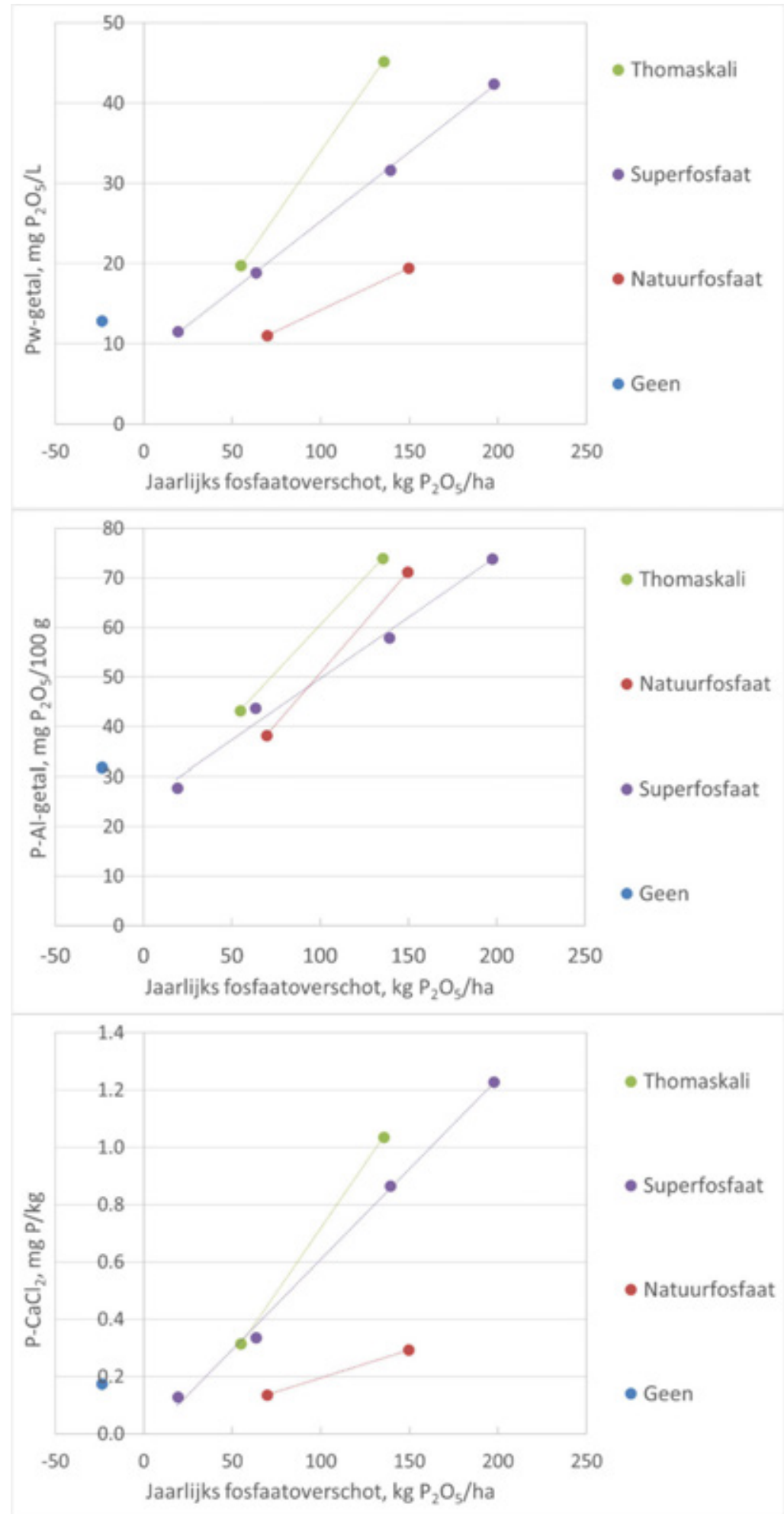

Figuur 4.11 Het gemiddelde Pw-getal (boven), P-Al-getal (midden) en P-CaCl 2 (onder) (2010-2016) bij gemiddelde jaarlijks fosfaatoverschot van behandelingen met zonder bemesting ( $g e e n$ ) en minerale fosfaatmeststoffen Thomaskali, Superfosfaat en Natuurfosfaat als functie van het jaarlijkse fosfaatoverschot, gemiddeld over de jaren 2010-2016. 
Ook na 44 jaar van het onthouden van enige vorm van fosfaatbemesting wordt de fosfaattoestand bepaald met P-Al-getal gewaardeerd als neutraal (gebruiksnormenstelsel grasland).

\subsubsection{Andere bodemtesten}

Bij alle locaties is vastgesteld dat het onthouden van fosfaatbemesting voor 31-44 jaren niet leidt tot drastische daling van de fosfaattoestand. Een continu toenemend overschot aan fosfaat leidt echter ook niet tot een continue stijging van de fosfaattoestand. In deze paragraaf wordt ingegaan op twee mogelijke oorzaken:

1. Bodemlagen onder de bouwvoor leveren na aan de bouwvoor;

2. Het residueel fosfaat van meststof wordt omgezet in fosfaatbodemfracties die niet tot uitdrukking komen in $\mathrm{P}-\mathrm{CaCl}_{2}$, Pw-getal en P-Al-getal. Die omzettingen worden gevolgd met andere extractiemethoden.

Bijdragen uit bodemlagen onder de bouwvoor kunnen verkend worden door die bodemlagen te bemonsteren (profielbemonsteringen). De fosfaatfracties in de verschillende bodemlagen kunnen worden bepaald.

Let op! Om vergelijking van waarden van verschillende methoden van grondonderzoek op fosfaat onderling te vergelijken, zijn alle waarden omgerekend naar $\mathrm{mg} \mathrm{P} / \mathrm{kg}$ grond.

Profielbemonsteringen zijn omvangrijke bemonsteringen en zijn in de periode 2000-2016 eenmalig (Marknesse $^{19}$ en Wijster) of twee keer uitgevoerd (Lelystad).

\subsubsection{Profielbemonstering in 2002}

$\mathrm{Na}$ de oogst werd in 2002 op de drie locaties het bodemprofiel bemonsterd in lagen 0-20, 20-30, 30-40, 40-50, 50-60, 60-80 en 80-100 cm. In 2002 bedroegen de fosfaatoverschotten in Lelystad bij $\mathrm{P} 1$-358 in $\mathrm{kg} \mathrm{P}_{2} \mathrm{O}_{5} / \mathrm{ha}$ en bij P4 4222 in $\mathrm{kg} \mathrm{P}_{2} \mathrm{O}_{5} / \mathrm{ha}$. In Marknesse waren bij geen bemesting de

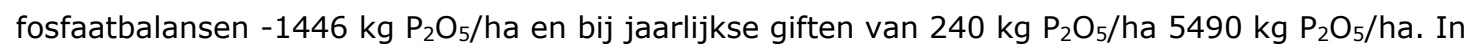

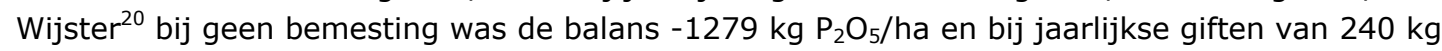
$\mathrm{P}_{2} \mathrm{O}_{5} /$ ha was de balans $5824 \mathrm{~kg} \mathrm{P}_{2} \mathrm{O}_{5} /$ ha. De verdeling van het fosfaatoverschot over het bodemprofiel en doorwerking daarvan naar de fosfaattoestand van de bodem werd bepaald met totaalfosfaat, P-Algetal, Pw-getal en P-1 op 2. Gegevens worden gepresenteerd in Figuur 4.12. P-1:2 is een een-optwee-extractie $(\mathrm{w} / \mathrm{v})$ van grond met water en geeft een indicatie ${ }^{21}$ voor de hoeveelheid fosfaat die in een bodemoplossing aanwezig kan zijn. Alle parameters zijn uitgedrukt in $\mathrm{mg} P / \mathrm{kg}$.

\section{Totaal-P}

De locaties verschillen zeer in fosfaatrijkdom. De gehalten aan totaalfosfaat in de bouwvoor zijn tussen de locaties vergelijkbaar, maar bodemlagen onder de bouwvoor verschillen zeer (Figuur 4.12). De ondergrond van Marknesse bevat meer fosfaat dan die in Lelystad. Beide zavelgronden zijn in de ondergrond rijker aan fosfaat dan de ondergrond van de zandgrond in Wijster. Effecten van veeljarige bemesting zijn tot in de laag 40-50 cm terug te vinden bij Lelystad en Wijster. Onder de 40-50 cm laag verschillen de bodemlagen per behandeling per locatie niet in het gehalte aan totaal-P. De proef in Marknesse daarentegen toont een verschil in behandeling aan tot in de bodemlaag 60-100 cm. De behandeling met jaarlijks $240 \mathrm{~kg} \mathrm{P}_{2} \mathrm{O}_{5} /$ ha heeft de fosfaattoestand verrijkt tot de bodemlaag 60-100 cm t.o.v. de niet-bemeste behandeling. Dit verschil kan zijn veroorzaakt doordat gewaswortels in de niet-bemeste behandeling fosfaat uit dieper gelegen bodemlagen transporteren naar minder diep gelegen bodemlagen in geval er sprake is van een negatieve fosfaatbalans. Bij een positieve fosfaatbalans kan het omgekeerde plaatsvinden: transport van fosfaat met wortels en andere biologische processen (wormen) uit de bouwvoor naar dieper gelegen bodemlagen. Ook fosfaatuitspoeling kan hieraan bijdragen, maar de mate van uitspoeling is te gering gelet op het verschil in totaal-P-gehalten (zie paragraaf 4.5 ).

${ }^{19}$ In Marknesse werden in de periode 1990-1999 in het kader van het IMPHOS West European Network in korte tijd bodemlagen 0-25, 30-40 en 45-65 cm bemonsterd. Grondmonsters werden geanalyseerd volgens methoden die standaard in Duitsland, België en Nederland voor bemestingsadvisering worden toegepast. In deze periode werd geen effect van de behandeling gevonden op veranderingen in bodemlagen onder de bouwvoor door het opgelegde bemestingsregime gericht op evenwichtsbemesting (Johnston et al., 2001).

20 De cumulatieve fosfaatbalans voor Wijster berust op een extrapolatie van de fosfaatafvoer berekend op basis van jaargemiddelden voor geteelde gewassen in periode dat de veldproef in slapende vorm werd voortgezet.

${ }^{21} \mathrm{P}-1: 2$ overschat licht de werkelijke concentratie in het bodemvocht, omdat directe nalevering bij de gegeven schudverhouding optreedt. 

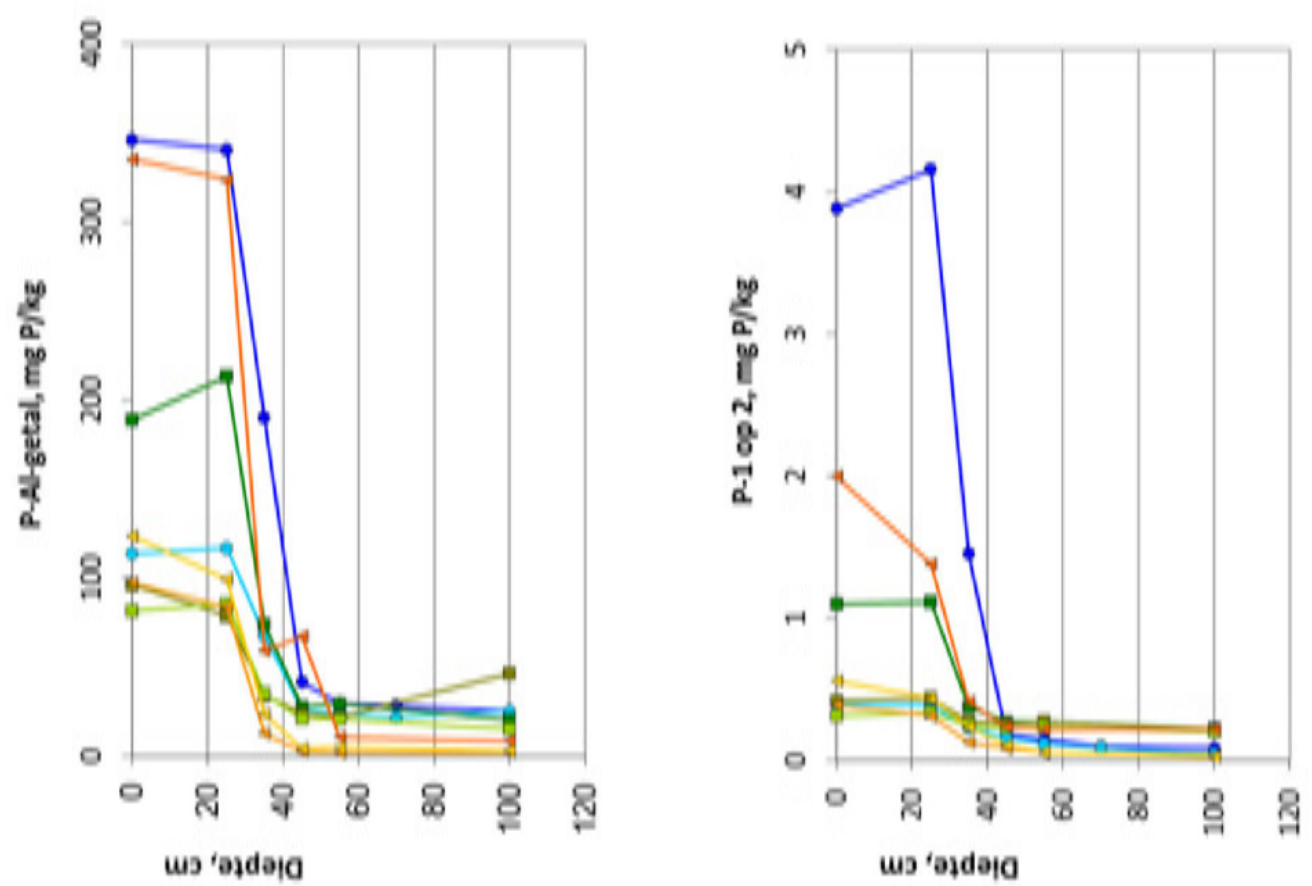

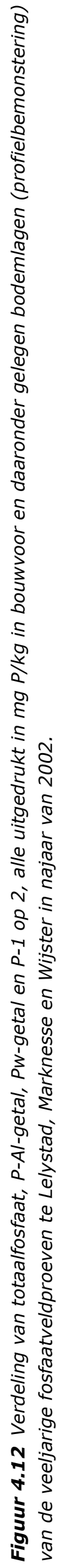
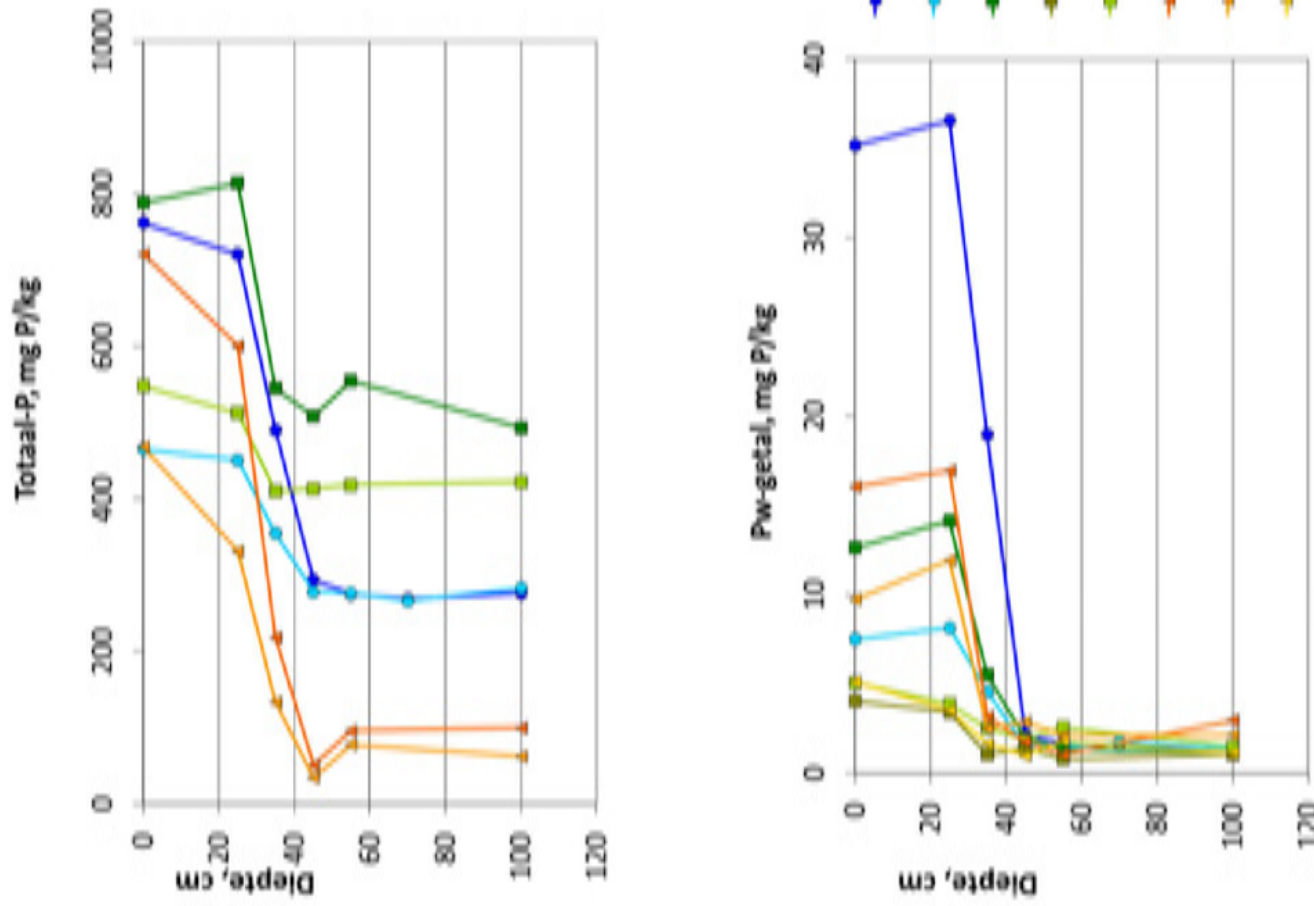


\section{P-Al-getal}

Naarmate er meer fosfaat gegeven wordt, wordt een hoger P-Al-getal in de bouwvoor vastgesteld (Figuur 4.12). Echter, de locaties verschillen in de mate waarin het P-Al-getal wordt verhoogd. Wijster heeft een hoger overschot dan Lelystad, maar geen hoger P-Al-getal, terwijl de waarden van het P-Algetal bij aanleg op deze locaties nauwelijks verschilden (Lelystad 122 mg P/kg en Wijster 105 mg $\mathrm{P} / \mathrm{kg}$ ). Ook Marknesse heeft een lager P-Al-getal dan Lelystad, terwijl het overschot hoger is (ca. $1600 \mathrm{~kg} \mathrm{P} \mathrm{O}_{5} / \mathrm{ha}$ ). Bij evenwichtsbemesting heeft Wijster een licht hoger P-Al-getal dan bij geen fosfaat bemesting, terwijl evenwichtsbemesting bij Marknesse niet tot een verschil leidt t.o.v. onbemest. Het P-Al-getal neemt af met de diepte. Hoge overschotten geven ook in bodemlagen tot 40-50 cm hogere waarden voor het P-Al-getal.

Hoewel het totaal-P-gehalte in de ondergrond (>50 cm) van Marknesse hoger is bij een

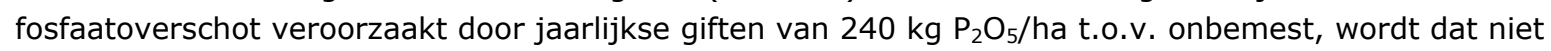
teruggevonden in het P-Al-getal. Waarden zijn dan van een vergelijkbare orde van grootte. Kennelijk wordt fosfaat in die ondergrond omgezet in vormen die niet met ammonium lactaat azijnzuur, het extractiemiddel voor de bepaling van het P-Al-getal, geëxtraheerd kunnen worden.

\section{Pw-getal}

Het Pw-getal is in Lelystad veel sneller gestegen dan in Marknesse of Wijster bij gelijke hoge overschotten (Figuur 4.12). Evenwichtsbemesting ( $45 \mathrm{~kg} \mathrm{P}_{2} \mathrm{O}_{5} / \mathrm{ha}$ ) te Wijster leidt tot een licht hoger Pw-getal t.o.v. de onbemeste behandeling in de bodemlaag onder de bouwvoor, terwijl er dan bij Marknesse geen wezenlijk verschil is. In de diepere ondergrond is nog geen effect van evenwichtsbemesting op het $\mathrm{Pw}$-getal vast te stellen.

$\mathbf{P -}_{1}$ op 2

Een fosfaatoverschot leidt tot stijging van $\mathrm{P}_{-1}: 2$. Deze stijging is bij positieve overschotten hoger bij Lelystad t.o.v. Marknesse of Wijster. Bij Marknesse en Wijster, waar de overschotten aanzienlijk hoger zijn, zijn de verhogingen de helft kleiner. Bij Wijster leidt evenwichtsbemesting tot een lagere waarde t.o.v. de onbemeste behandeling, bij Marknesse is er geen verschil.

\section{Algemene bevindingen profielbemonstering}

De resultaten van de profielbemonstering in 2002 wijzen uit dat het lot van het fosfaatoverschot per locatie verschilt. De beschikbaarheid van het fosfaatoverschot blijft het grootst op de locatie te Lelystad. Bij Marknesse en Wijster, proeven met een veel langere looptijd, is een groter deel van het fosfaatoverschot niet meer terug te vinden in een verandering van het Pw-getal of het P-Al-getal. Op zavelgronden stijgt het P-Al-getal wel in de ondergrond bij een fosfaatoverschot, maar dit leidt nog niet tot een stijging van het $\mathrm{Pw}$-getal of $\mathrm{P}_{-1}$ op 2 . Bij Wijster wordt daarentegen wel een indicatie voor een stijging van deze parameters gevonden. Bij evenwichtsbemesting wordt bij Marknesse geen effect in wijziging van de fosfaattoestand in de bouwvoor en daaronder gelegen bodemlagen vastgesteld. Effecten van evenwichtsbemesting bij Lelystad worden hieronder besproken.

\subsubsection{Herhaalde profielbemonstering te Lelystad in 2009}

In Figuur 4.13 is het resultaat weergegeven van de profielbemonsteringen in meerdere bodemlagen tot $100 \mathrm{~cm}$ diepte die in 2002 en 2009 te Lelystad werden uitgevoerd. Bij de behandelingen P2, P3 en P4 wordt meer fosfaat aangevoerd dan afgevoerd. Het totaal-P-gehalte neemt dan ook toe in bouwvoor en direct daaronder gelegen bodemlagen.

Het P-Al-getal is in 2009 wat lager in de bouwvoor bij de vier behandelingen (P1, P2 bemest, P3 bemest en $\mathrm{P} 4$ bemest) dan in 2002, terwijl in de aangrenzende ondergrond (tot $50 \mathrm{~cm}$ diepte) het $\mathrm{P}$-Al-getal is gestegen.

Bij P2 is het Pw-getal in de bouwvoor niet veranderd, maar in de ondergrond neemt ook het Pw-getal wat toe (groene lijn). Tot een diepte van $50 \mathrm{~cm}$ in 2009 zijn effecten van P2 (bemest) in de bodemlagen onder de bouwvoor hoger dan bij P1. Bij P3 (bemest) en P4 (bemest) is het Pw-getal zowel in de bouwvoor als in de ondergrond toegenomen. Het fosfaatoverschot werkt door tot een diepte van $70 \mathrm{~cm}$ in 2009. Het resultaat bij P3 zit tussen dat van P2 en P4 in. Bij P1 zijn totaal-P, P-Al-getal en Pw-getal in 2009 lager dan in 2002. $\mathrm{P}_{-1}$ op 2 is daarentegen wat hoger, maar de niveaus zijn laag.

P2 bemest benadert evenwichtsbemesting. Ondanks een lichte daling in de bouwvoor en een lichte stijging in de ondergrond, blijft het totaal-P-gehalte in het bodemprofiel gelijk. Het P-Al-getal lijkt in de bouwvoor af te nemen ten gunste van een toename in de ondergrond. Het Pw-getal neemt niet af in de periode 2002-2009. $\mathrm{P}_{-1}$ op 2 neemt toe, vooral in bodemlagen onder de bouwvoor. 

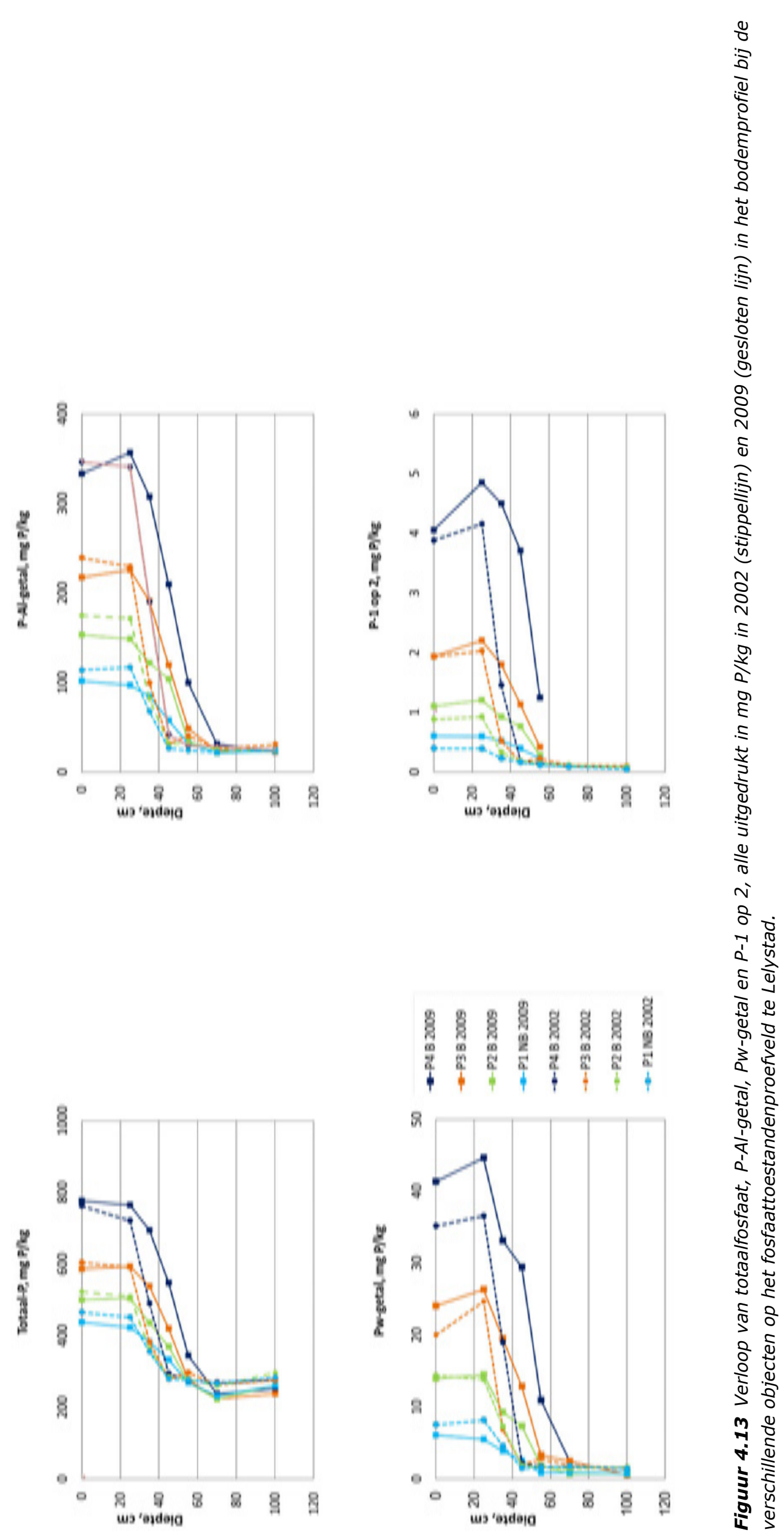

Wageningen Environmental Research Rapport 2906 | 81 


\subsubsection{Verdeling van reversibel en quasi-irreversibel gebonden bodemfosfaat}

In paragraaf 3.4.3 is schematisch aangegeven welke fosfaatfractie in de bodem met de verschillende gehanteerde P-analyses wordt bepaald. Bij de bouwlandproeven is bij de profielbemonstering een aantal onderzoeksmethoden toegepast die indicaties geven over de snelheid waarmee fosfaat desorbeerbaar is. Reversibel gebonden fosfaat $(\mathrm{Q})$ is de fractie bodemfosfaat die snel en makkelijk desorbeerbaar is. Dit is de fractie die nalevert aan $\mathrm{P}-\mathrm{CaCl}_{2}$ en het $\mathrm{Pw}$-getal (zie paragraaf 3.4.3). In het onderzoek is makkelijk desorbeerbaar fosfaat bepaald met behulp van filterpapier dat met ijzerhydroxide is geïmpregneerd (Pi-methode). Daarnaast is een fractie fosfaat aanwezig dat traag beschikbaar komt (S). Pas op de (zeer) lange termijn komt dit fosfaat beschikbaar voor het gewas. Q en $\mathrm{S}$ bepalen de totale gewasbeschikbaarheid van mineraal fosfaat in de bodem en hebben daardoor een relatie met de parameters voor de bemestingsadviezen (grasland P-Al-getal; bouwland Pw-getal of $\mathrm{P}-\mathrm{CaCl}_{2}$ en $\mathrm{P}$-Al-getal). De totale hoeveelheid gewas-beschikbaar fosfaat $(\mathrm{Q}+\mathrm{S})$ is bepaald met ammonium oxalaat azijnzuur (P-ox).

$\mathrm{P}$-ox, Q en S werden bepaald in grondmonsters van geselecteerde bodemlagen (0-20 en $30-40 \mathrm{~cm}$ ) van de drie locaties van de profielbemonstering van 2002. Voor Lelystad werden deze analyses in 2009 herhaald. De hoeveelheid geëxtraheerd fosfaat werd gerelateerd aan het fosfaatbindend vermogen van de bodem (Al-ox + Fe-ox). In figuren 4.14 en 4.15 worden de resultaten op mol-basis $\mathrm{P}-\mathrm{ox} /(\mathrm{Al}-\mathrm{ox}+\mathrm{Fe}-\mathrm{ox}), \mathrm{S} /(\mathrm{Al}-\mathrm{ox}+\mathrm{Fe}-\mathrm{ox})$ en Q/(Al-ox + Fe-ox $)$ gegeven.

De hoeveelheid sorbeerbaar fosfaat (P-ox) stijgt sterker met het fosfaatoverschot bij Lelystad dan bij Marknesse en Wijster (Figuur 4.14). Dit kan een gevolg zijn van de langere contactduur van residuair meststof fosfaat met de bodems van Marknesse en Wijster: fosfaat heeft daar langer de tijd gehad om te reageren tot niet/slecht desorbeerbare fracties.

In de laag $0-20 \mathrm{~cm}$ beneden maaiveld is op alle locaties rond de $20 \%$ van P-ox in snel en makkelijke desorbeerbare vorm aanwezig bij de behandeling met de hoogste aanvoer van fosfaat. In de laag 30-40 cm (Figuur 4.15) is dit percentage circa de helft lager (Figuur 4.15). Deze makkelijk desorbeerbare fracties correleren met $\mathrm{P}_{-1}$ op 2 (data niet gegeven).

De hoeveelheid reversibel gebonden fosfaat op alle locaties is in 2002 zelfs na het achterwege laten van fosfaatbemesting over 16 respectievelijk 32 jaar veel hoger dan een landbouwgewas direct nodig

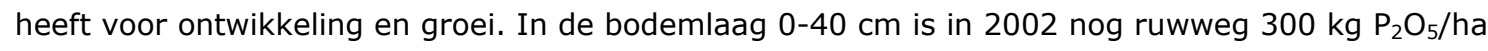
aanwezig. De bodem is dus ook na jarenlang uitmijnen nog steeds in staat om fosfaat na te leveren. De bodem buffert.

In 2009 werd de profielbemonstering te Lelystad herhaald en een selectie van de grondmonsters werd geanalyseerd op P-ox/(Al-ox + Fe-ox), S/(Al-ox + Fe-ox) en Q/(Al-ox + Fe-ox) en P-ox (mmol/kg) gegeven. In de periode 2002-2009 is het fosfaatoverschot van bij P2 bemest, P3 bemest en P4 bemest verder toegenomen naar respectievelijk 53, 641 en 1843 kg $\mathrm{P}_{2} \mathrm{O}_{5} /$ ha, bij $\mathrm{P}$ onbemest nam het overschot af tot $-874 \mathrm{~kg} \mathrm{P} \mathrm{O}_{5} / \mathrm{ha}$. Het beeld dat in 2002 werd vastgesteld, wordt ook in 2009 weer gevonden (Figuur 4.16). De fracties gesorbeerd fosfaat (P-ox, $\mathrm{S}$ en Q) nemen evenredig toe met toename van het cumulatieve fosfaatoverschot. Ondanks een toename van het fosfaatoverschot van $1843 \mathrm{~kg} \mathrm{P}_{2} \mathrm{O}_{5} /$ ha bij P4 bemest, blijft de makkelijk uitwisselbare fosfaatfractie onder de 0,05. P-ox blijkt wel te reageren op een hoger wordend fosfaatoverschot, maar dat komt nauwelijks tot uitdrukking in $\mathrm{Q}$.

Ook in 2009, na 23 jaar achterwege laten van fosfaatbemesting, is de hoeveelheid makkelijk uitwisselbaar fosfaat (Q) veel hoger dan een landbouwgewas direct nodig heeft.

\subsubsection{Stand van zaken bij de profielbemonstering}

De profielbemonsteringen leren dat een overschot aan fosfaat niet uitsluitend accumuleert in de bouwvoor, maar ook in bodemlagen onder de bouwvoor.

De bodemlagen onder de bouwvoor op de zavels zijn rijker aan fosfaat dan die op dekzand. De zavel van Marknesse is onder de bouwvoor rijker aan fosfaat dan de zavel van Lelystad. De rijkdom onder de bouwvoor wordt opgevat als een oorzaak waarom een gewasreactie op 
fosfaatbemesting bij Marknesse geringer is dan die te Lelystad. Hierin wordt een aanwijzing gevonden dat bodemlagen onder de bouwvoor fosfaat leveren aan de bouwvoor,

Profielbemonsteringen te Marknesse en Wijster zijn momentopnames voor 2002. Voor deze locaties geeft de profielbemonstering geen uitsluitsel of residueel fosfaat van meststof wordt omgezet in fosfaatbodemfracties die niet tot uitdrukking komen in $\mathrm{P}-\mathrm{CaCl}_{2}$, Pw-getal en P-Al-getal. Voor de locatie Lelystad wordt wel een aanwijzing gevonden: een deel van het fosfaatoverschot wordt teruggevonden in P-ox. 


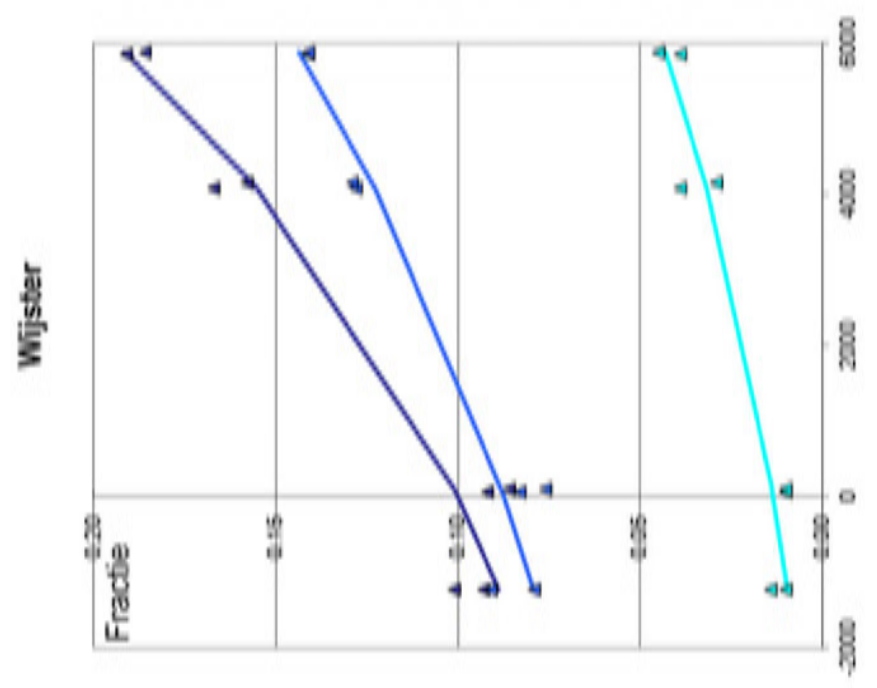

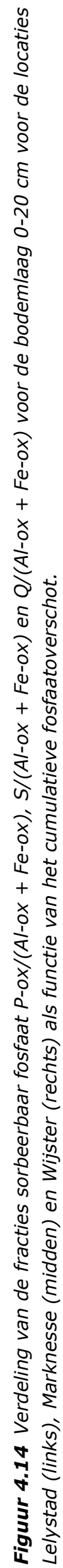
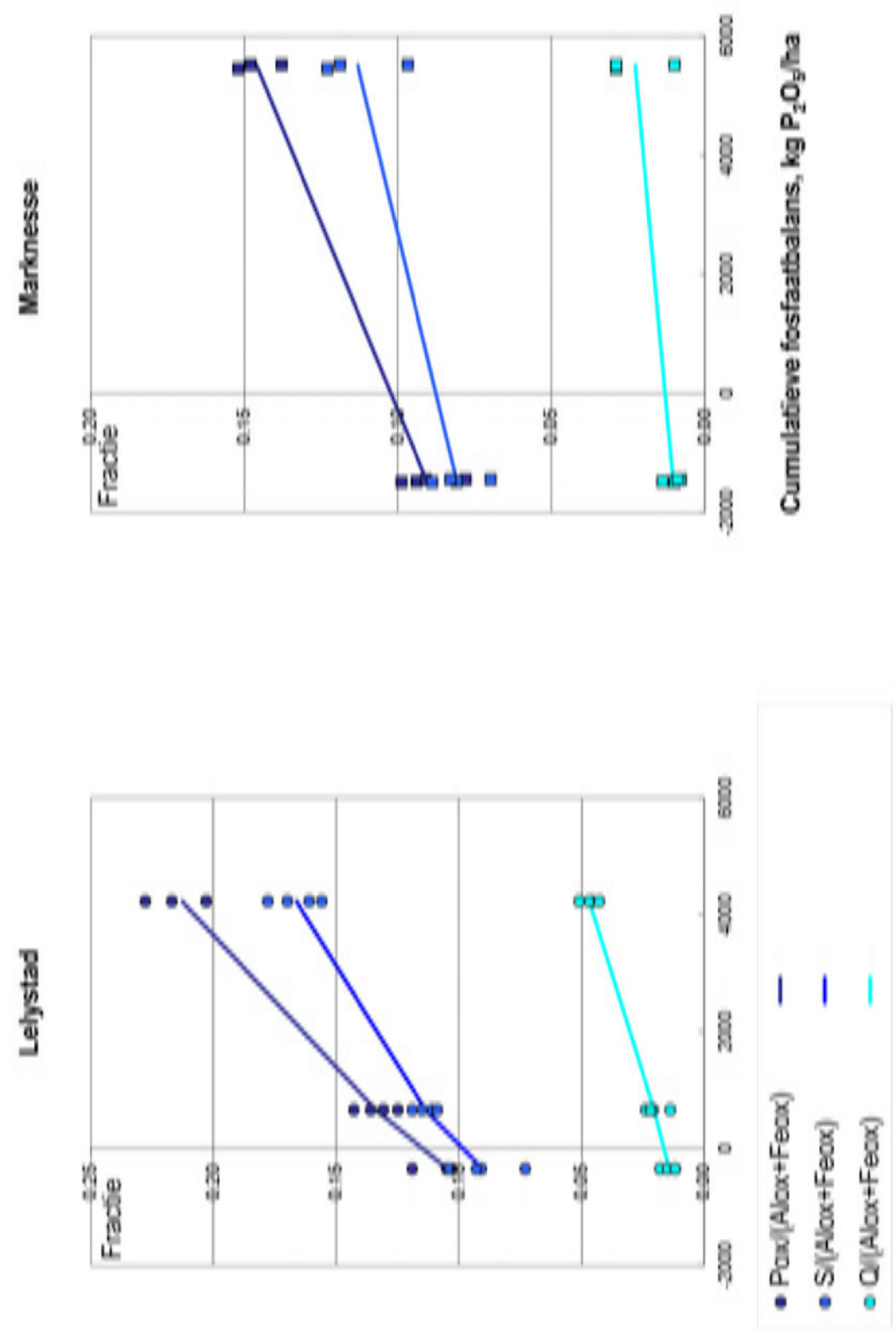


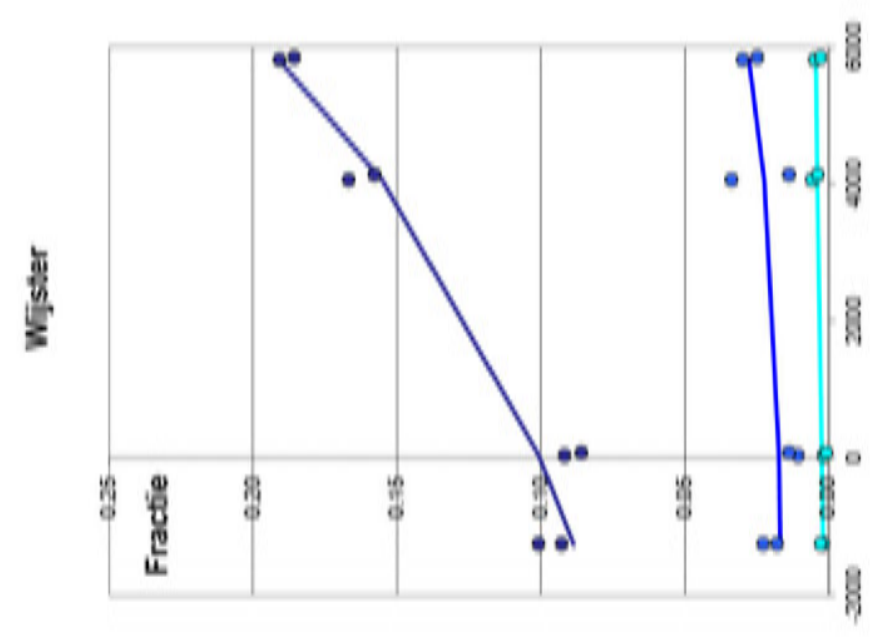

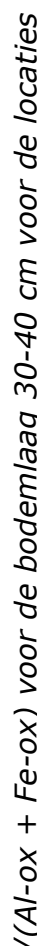
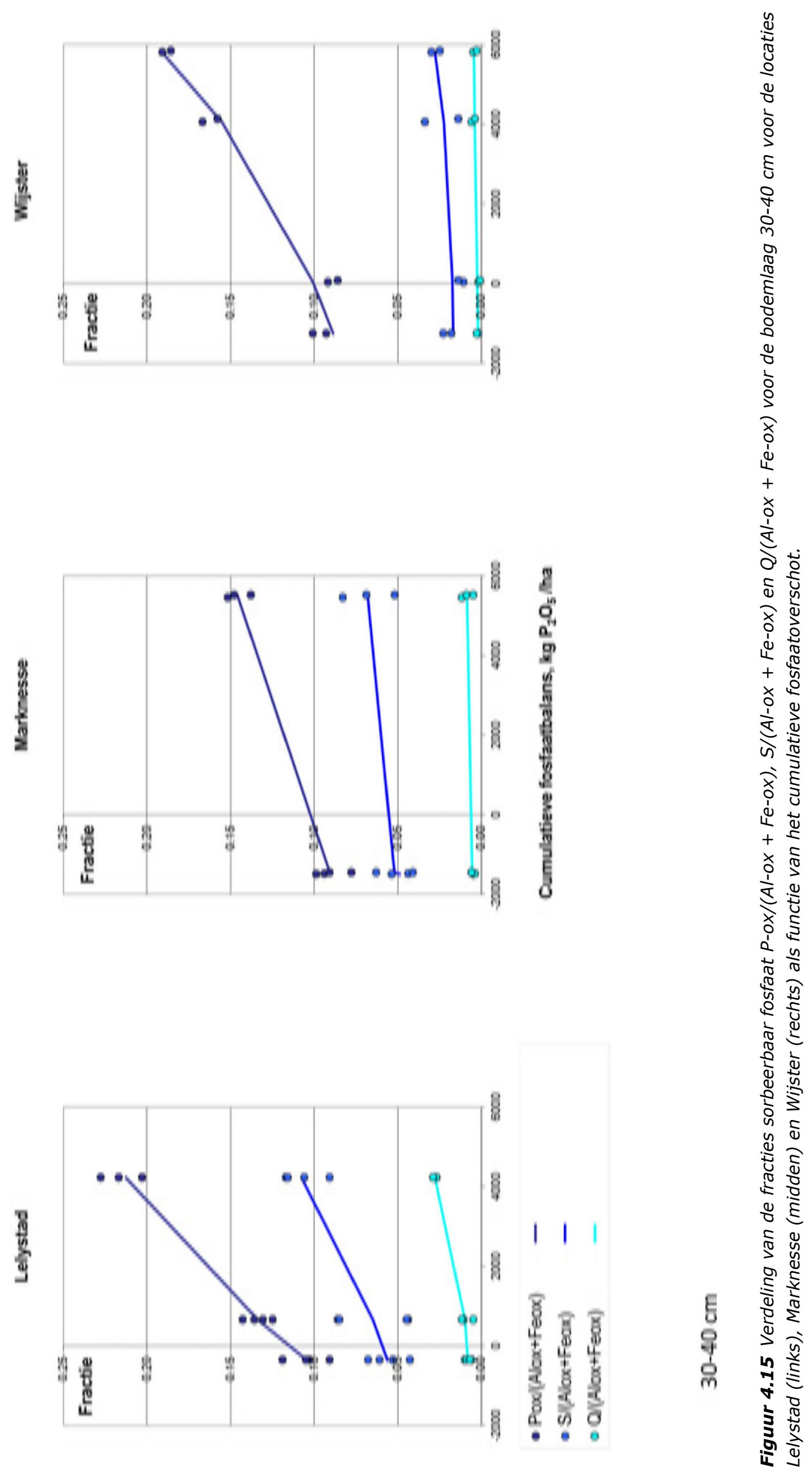


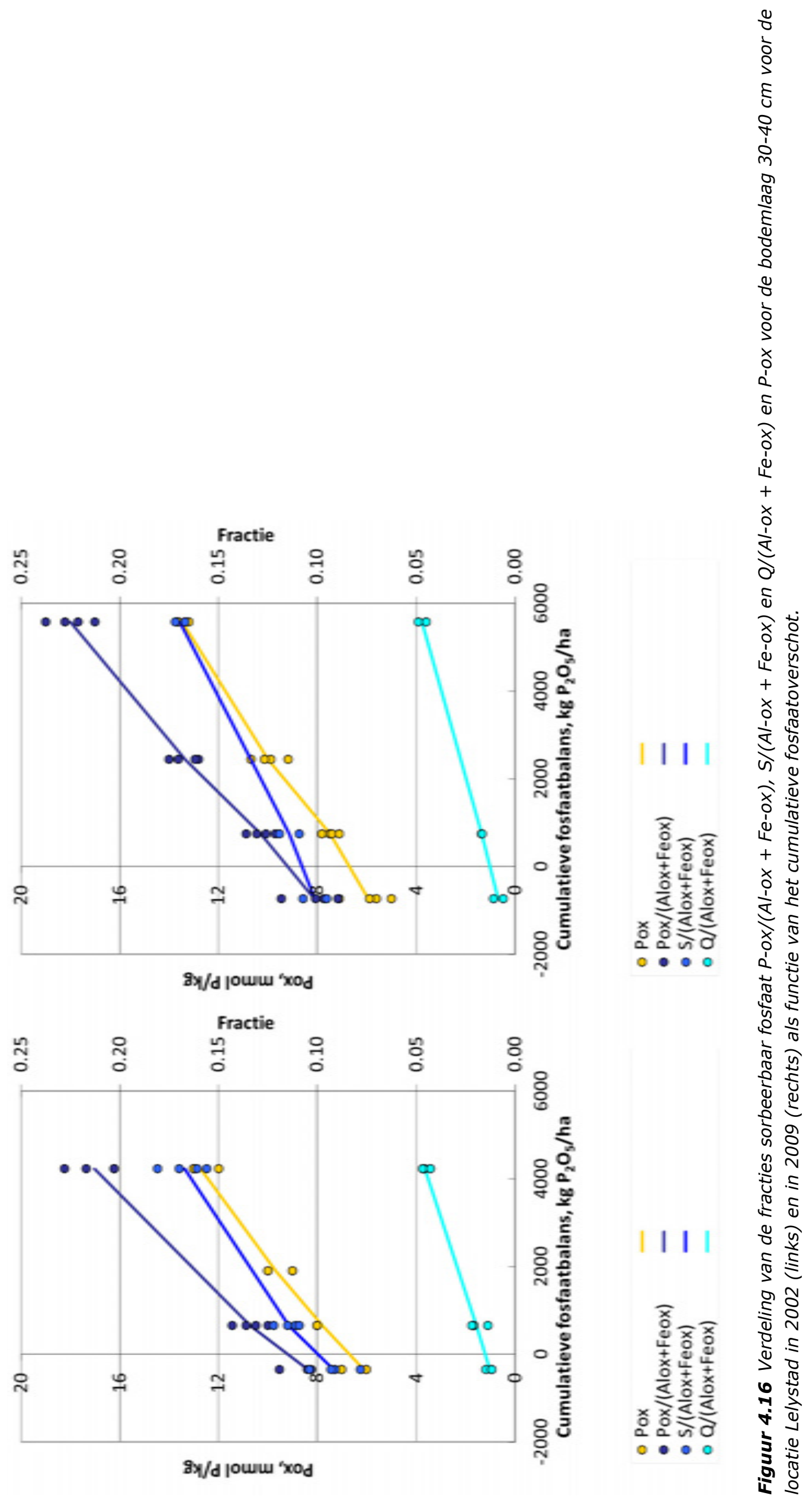

86 | Wageningen Environmental Research Rapport 2906 


\subsubsection{Organische stof}

De veldproeven op bouwland onderzoeken het lot van mineraal fosfaat toegediend aan de akkerbodem. Organische stof is daardoor geen behandeling in een proefopzet. Uitsluitsel of veeljarige toepassing van evenwichtsbemesting tot een mogelijke wijziging in het gehalte aan organische stof in de bouwvoor (en daaronder gelegen bodemlagen) leidt, kan alleen door observationeel onderzoek vastgesteld worden. Daarvoor zijn meetgegevens nodig van het beloop van de organischestofgehalten in de tijd per object. Deze gegevens werden, gelet op de doelstellingen van de veldproeven, niet ${ }^{22}$ bepaald in Lelystad. In Marknesse en Wijster zijn enkele trends beschikbaar. Beschikbare gegevens worden daarom ook met enkele literatuurgegevens samengebracht en in deze subparagraaf behandeld.

Over het organische-stofgehalte van de bouwvoor kunnen de volgende generieke achtergronden gegeven worden.

Volgens Van Dijk et al. (2007) geven modelberekeningen het beeld dat een fosfaatgebruiksnorm van $60 \mathrm{~kg}$ per ha nauwelijks effect heeft op het organische-stofgehalte in de bodem, ook niet op langere termijn. Door de relatief grote bijdrage van gewasresten neemt de aanvoer van effectieve organische stof op bedrijfsniveau op de meeste modelbedrijven nauwelijks af en kan op vrijwel alle bedrijven op het niveau blijven dat in 2006 mogelijk was. In sommige gevallen vereist dit een aanpassing van de organische-mestsoort: bijvoorbeeld vervanging van (een deel) van varkensdrijfmest, die relatief weinig bijdraagt aan de instandhouding van bodem-organische stof door rundveemest of compost die daar veel meer aan bijdragen.

Schils et al. (2012) achten het onwaarschijnlijk dat het mestbeleid grootschalige negatieve effecten heeft op het organische-stofgehalte van bouwland. Voor de bloembollenteelt op duinzandgrond geven ze aan dat er (in 2012) nog geen volledig uitsluitsel was of de teelt lijdt onder de gebruiksnormen.

Schröder en Van Dijk (2017) geven aan dat in de gebruikelijke bouwplannen in Nederland in de meeste gevallen met alleen achterlaten van gewasresten en de teelt van groenbemesters niet kan worden voldaan aan de ondergrens van de benodigd geachte aanvulling van organische stof. In combinatie met het achterlaten van graanstro wordt de kans op tekorten kleiner. Vooral als de wens bestaat om een hoog organische-stofgehalte te handhaven, is het bij bestaande bouwplannen onmogelijk om dat zonder toediening van rundveemest of compost te realiseren. Op zichzelf laat de fosfaatgebruiksnorm toe om die benodigde rundveemest of compost aan te voeren.

Observaties voor het beloop van het organische-stofgehalte bij vier behandelingen te Marknesse worden gegeven in Figuur 4.17, voor Wijster in Figuur 4.18. De observaties betreffen grondmonsters genomen voorafgaand aan de teelt van aardappel. Bij Marknesse wordt geen aanwijzing gevonden dat het organische-stofgehalte geleidelijk aan het dalen is. Waarden voor de organische-stofgehalten schommelen rond de $2,6 \%$.

Het organische-stofgehalte van de bouwvoor te Wijster varieert tussen de veldjes. De veldproef blijkt qua organische-stofgehalte heterogeen te zijn. Binnen een behandeling is er over de jaren eerder sprake van een toename in organische-stofgehalte.

Beschikbare meetgegevens, zij het beperkt in aantal waarnemingen, geven aan dat evenwichtsbemesting met mineraal fosfaat niet leidt tot een daling van het organische-stofgehalte.

\footnotetext{
${ }^{22}$ Vanaf 2017 zullen o.s.-gehalten in de proef te Lelystad frequenter gemeten gaan worden.
} 


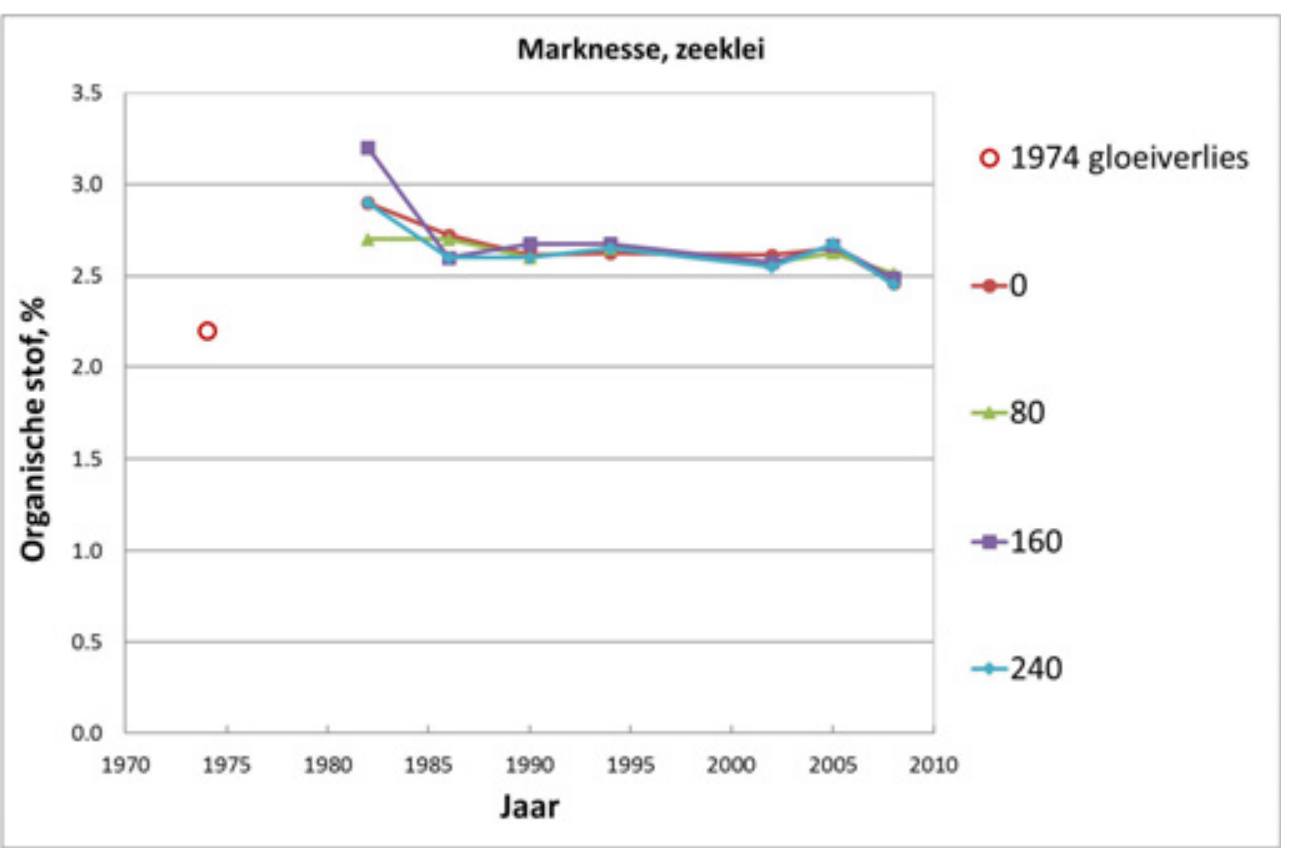

Figuur 4.17 Het beloop van het organische-stofgehalte in \% te Marknesse bij vier fosfaatgiften. In 1974 werd het organische-stofgehalte met de gloeiverliesmethode bepaald. Overige metingen zijn gebaseerd op NIRS ${ }^{23}$.

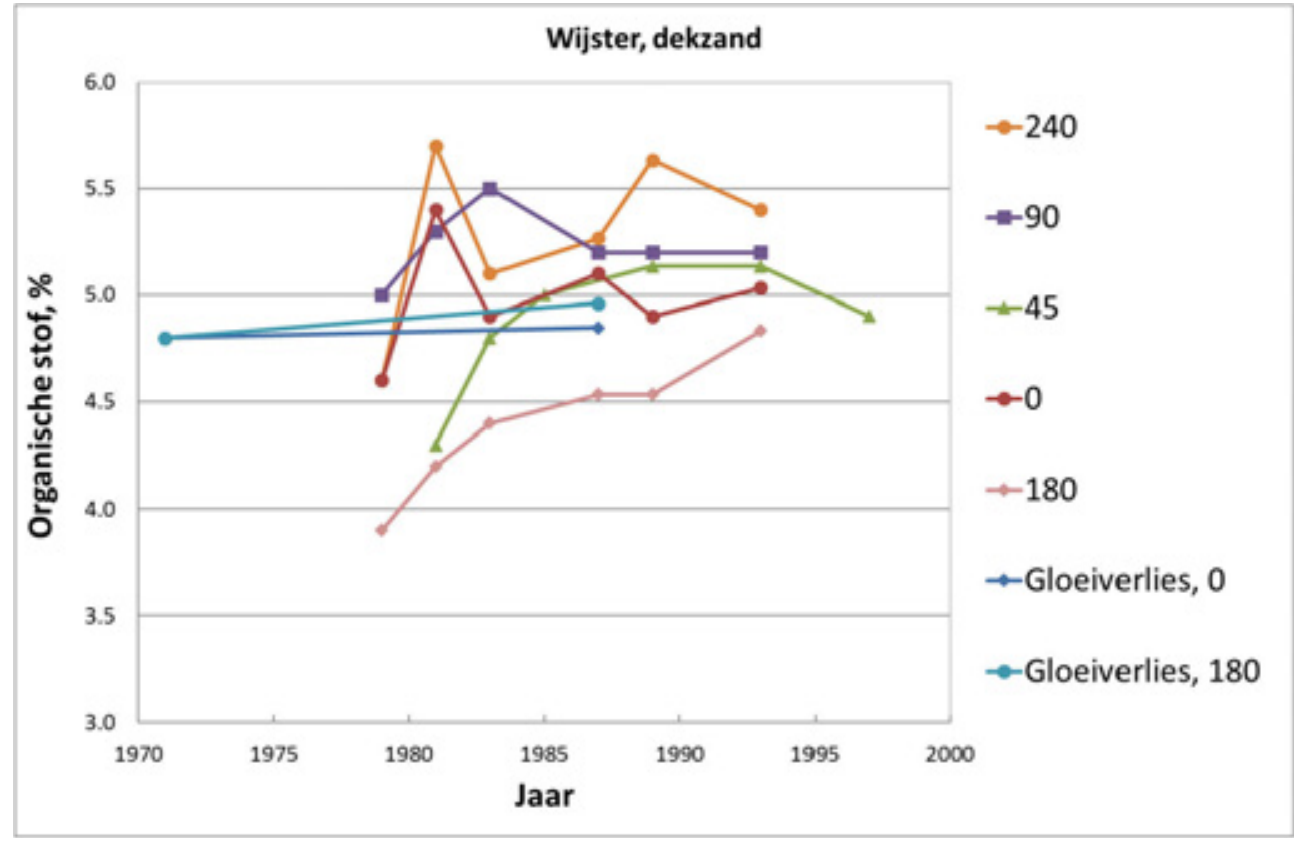

Figuur 4.18 Het beloop van het organische-stofgehalte in \% te Wijster bij vier fosfaatgiften. In 1972 en 1986 werd het organische-stofgehalte met de gloeiverliesmethode bepaald (blauwe symbolen en lijnen). Het betreft waarden voor de gehele veldproef. Overige metingen zijn gebaseerd op gemiddelden per fosfaatgift bepaald met NIRS.

\footnotetext{
${ }^{23}$ NIRS: Nabij InfraRood Spectrofotometrie. Beschikbare meetgegevens berusten op recente metingen aan gearchiveerde grondmonsters (2017).
} 


\subsubsection{Uitmijnen van fosfaat}

In paragraaf 4.3.1 is in Figuur 4.3 voor de veldproef te Lelystad het beloop gegeven van de fosfaattoestand (Pw-getal) in de tijd indien na opbouw van de fosfaattoestand fosfaatbemesting onthouden wordt (uitmijnen). De fosfaattoestand daalt direct na het stoppen van fosfaatbemesting. Figuur 4.3 geeft een aanwijzing dat in de eerste jaren van het onthouden van fosfaatbemesting de fosfaattoestand sterker daalt dan in de daaropvolgende jaren. De variatie van jaar tot jaar is groot en beïnvloedt de trend. In een periode van elf jaar leidt uitmijnen bij de veldproef te Lelystad tot wijziging van de fosfaatklassen. Bij P4 was in 2005 de fosfaatklasse hoog, in 2016 blijft de waardering nog steeds hoog, ondanks het onthouden van fosfaatbemesting. Bij P3 verschuift de fosfaatklasse van hoog naar neutraal en bij P2 van neutraal naar laag (Figuur 4.3).

Ervaring met uitmijnen op de veldproef te Marknesse werd opgedaan in de periode 1987-1990 bij een aantal behandelingen met gloeifosfaat. Toen de bemesting met fosfaat werd gestopt, werd het beloop van de fosfaattoestand gevolgd. In deze korte periode van vier jaar werd geen wezenlijke daling van de fosfaattoestand (Pw-getal, P-Al-getal) vastgesteld.

In de veldproef te Wijster wordt het effect van uitmijnen vanaf 1988 gevolgd. Tot 1988 waren

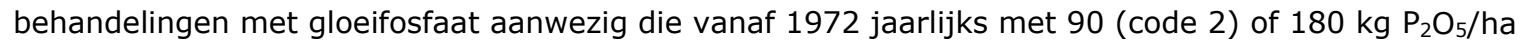
(code 3) bemest waren. In 1987 leidde dat tot een cumulatief fosfaatoverschot van respectievelijk

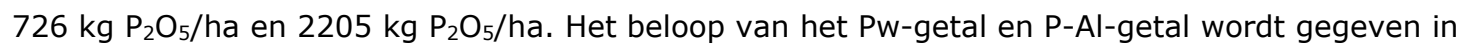
respectievelijk de figuren 4.19 en 4.20. In 2016 waren de cumulatieve fosfaatoverschotten gedaald tot -272 en $1048 \mathrm{~kg} \mathrm{P}_{2} \mathrm{O}_{5} / \mathrm{ha}$.

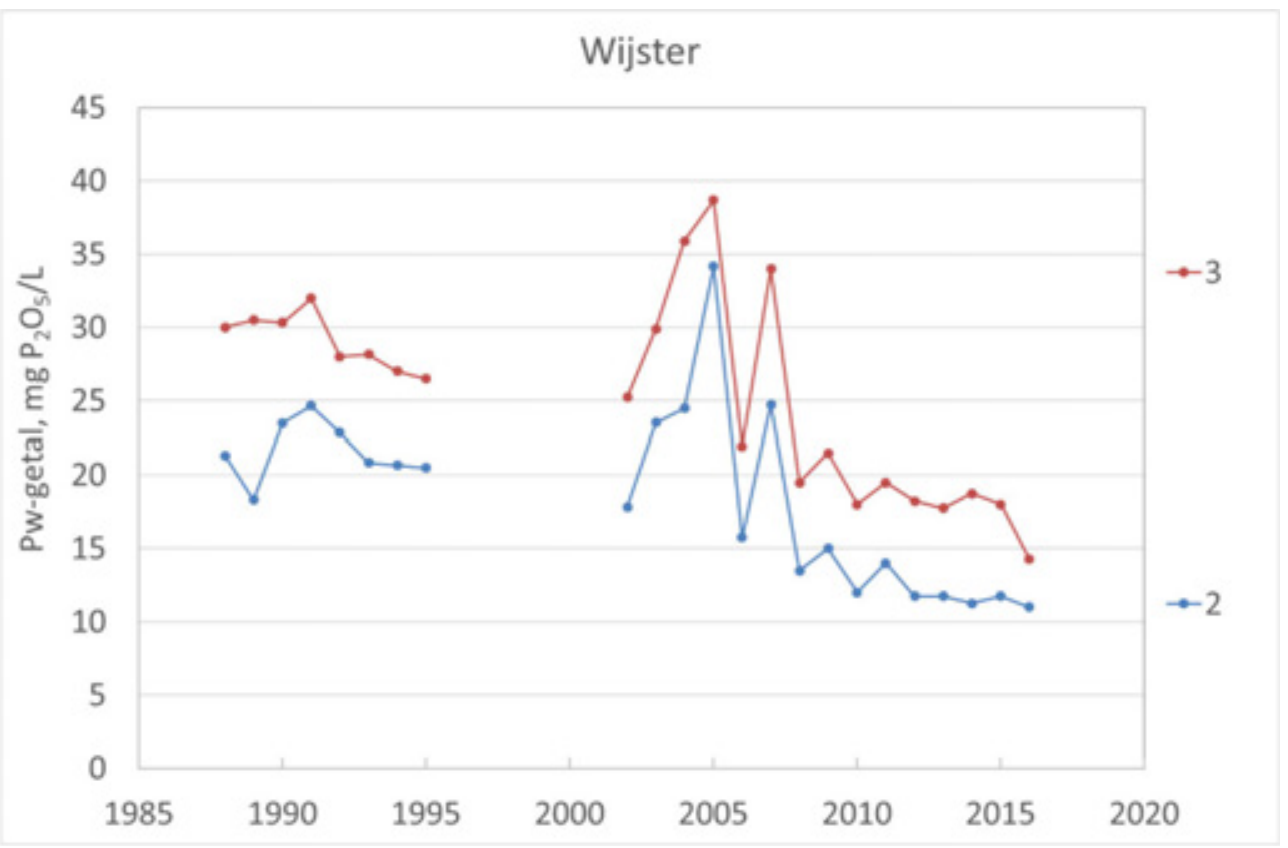

Figuur 4.19 Beloop van het $P w$-getal in $\mathrm{mg} \mathrm{P}_{2} \mathrm{O}_{5} / \mathrm{L}$ in de bouwvoor van behandelingen die tot 1987 verrijkt werden met gloeifosfaat fosfaat en daarna op uitmijnen werden gelegd. In 1987 was het cumulatieve fosfaatoverschot $726 \mathrm{~kg} \mathrm{P}_{2} \mathrm{O}_{5} / \mathrm{ha}$ (code $2^{24}$ ) of $2205 \mathrm{~kg} \mathrm{P}_{2} \mathrm{O}_{5} /$ ha (code $3^{25}$ ). In de periode 1996-2001 werd geen grondonderzoek uitgevoerd.

Het verschil in fosfaatoverschot leidt tot een verschil in fosfaattoestand. Een hoger overschot leidt tot een hogere fosfaattoestand (Pw-getal, P-Al-getal). De fosfaattoestand daalt geleidelijk. Het verschil in fosfaattoestand veroorzaakt door verschil in cumulatieve fosfaatbalans blijft gedurende de periode

\footnotetext{
${ }^{24}$ Code 2: Dit cumulatieve fosfaatoverschot is afkomstig van jaarlijkse giften van $90 \mathrm{~kg} \mathrm{P}_{2} \mathrm{O}_{5} / \mathrm{ha}$ als gloeifosfaat van 1972 tot 1987.

${ }^{25}$ Code 3: Dit cumulatieve fosfaatoverschot is afkomstig van jaarlijkse giften van $180 \mathrm{~kg} \mathrm{P} \mathrm{P}_{5} /$ ha als gloeifosfaat van 1972 tot 1987.
} 
1988-2016 in stand. In 1987 werd op basis van het Pw-getal gestart in klasse laag (code 2) of neutraal (code 3). Na 29 jaar uitmijnen hebben beide behandelingen de klasse laag bereikt.

Voor bouwland is er anno 2017 geen klasseindeling gebaseerd op P-Al-getal. Indien gespiegeld wordt aan de klasseindeling van P-Al-getal zoals die geldt voor grasland, blijkt dat het P-Al-getal geleidelijk daalt bij uitmijnen. In 1987 wordt de fosfaattoestand als neutraal (grasland) gewaardeerd. Die waardering blijft ongewijzigd gedurende een periode van 29 jaar.

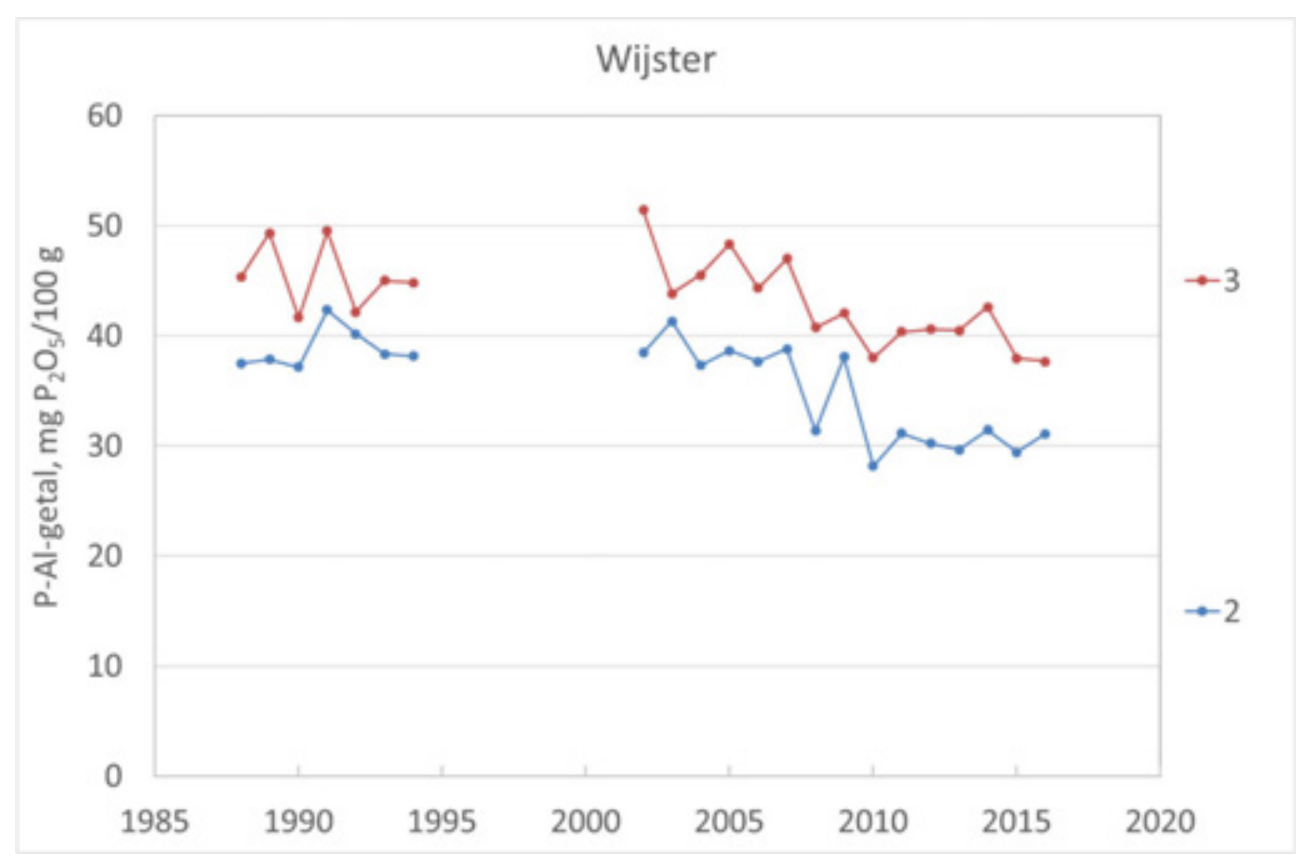

Figuur 4.20 Beloop van het $P$-Al-getal in $\mathrm{mg} \mathrm{P}_{2} \mathrm{O}_{5} / 100 \mathrm{~g}$ in de bouwvoor van behandelingen die tot 1987 verrijkt werden met gloeifosfaat fosfaat en daarna op uitmijnen werden gelegd. In 1987 was het cumulatieve fosfaatoverschot $726 \mathrm{~kg} \mathrm{P}_{2} \mathrm{O}_{5} /$ ha (code 2) of $2205 \mathrm{~kg} \mathrm{P}_{2} \mathrm{O}_{5} / \mathrm{ha}$ (code 3). In de periode 1996-2001 werd geen grondonderzoek uitgevoerd.

\subsection{Landbouwkundig en bodemkundig perspectief}

\subsubsection{Fosfaatafvoer in gewasrotatie}

Bij bemestingsplannen voor fosfaat wordt op akkerbouw- en vollegrondsgroentebedrijven rekening gehouden met het bouwplan (gewasrotatie). Fosfaat wordt zo veel mogelijk gegeven aan gewassen die op fosfaatbemesting reageren (gewasgroepen 0 en 1 ). Het gebruik van dierlijke mest leidt echter ook tot bemesting van gewassen van overige gewasgroepen met fosfaat, bijvoorbeeld tarwe. Bemestingsproducten gemaakt van dierlijke mest leveren mogelijkheden om gerichter nutriënten in te zetten dan dierlijke mest. In deze paragraaf wordt effecten van managementpraktijken met fosfaatevenwichtsbemesting besproken.

Gegevens over fosfaatgehalten in landbouwgewassen en fosfaatafvoer zijn gerapporteerd door Ehlert et al. (2009). Bij deze rapportage werden gegevens van de veeljarige veldproeven betrokken naast gegevens van andere veldproeven en uit de praktijk. De studie geeft een rubricering naar fosfaattoestand en gebruik van fosfaat- en stikstofmeststof. Op basis van arealen landbouwgewassen van Wageningen Economic Research (het voormalige LEI), vastgestelde mediaanwaarden voor fosfaatafvoercijfers en de opgelegde rubricering werd voor bouwland een gemiddeld fosfaatafvoercijfer van 52,9 kg $\mathrm{P}_{2} \mathrm{O}_{5} /$ ha berekend. De studie van Ehlert et al. (2009) geeft achtergronden wanneer de feitelijke fosfaatafvoer gaat afwijken van een fosfaatafvoer van $60 \mathrm{~kg} \mathrm{P}_{2} \mathrm{O}_{5} / \mathrm{ha}$. 
De veldproeven te Marknesse en Wijster hebben fosfaatafvoercijfers bij evenwichtsbemesting die rond de generiek bepaalde fosfaatafvoercijfers liggen. De veldproef te Lelystad representeert de centrale kleigebieden waarvan bekend is dat de fosfaatafvoercijfers hoger liggen (Ehlert et al., 2009).

In Tabel 4.12 is de fosfaatbalans weergegeven voor een voorbeeldbouwplan op centrale zeeklei bij toestand P2 (neutraal) en een jaarlijkse bemesting van $70 \mathrm{~kg} \mathrm{P}_{2} \mathrm{O}_{5}$ per ha. De cijfers van de fosfaatafvoer zijn gebaseerd op de fosfaattoestandenproef te Lelystad (zie paragraaf 4.2.1).

Tabel 4.12 Fosfaatbalans voor een voorbeeldbouwplan op centrale zeeklei bij neutrale fosfaattoestand en een jaarlijkse bemesting van $70 \mathrm{~kg} \mathrm{P}_{2} \mathrm{O}_{5}$ per ha.

\begin{tabular}{|c|c|c|c|c|c|}
\hline \multirow[t]{2}{*}{ Gewas } & \multirow[t]{2}{*}{$\begin{array}{l}\text { Aandeel in het } \\
\text { bouwplan }(\%)\end{array}$} & \multicolumn{2}{|c|}{$\begin{array}{l}\text { Fosfaatafvoer } \\
\left.\text { (kg } \mathrm{P}_{2} \mathrm{O}_{5} / \mathrm{ha} / \mathrm{jaar}\right)\end{array}$} & \multicolumn{2}{|c|}{$\begin{array}{l}\text { Fosfaatoverschot } \\
\text { (kg } \mathrm{P}_{2} \mathrm{O}_{5} / \mathrm{ha} / \mathrm{jaar} \text { ) }\end{array}$} \\
\hline & & Per ha & $\begin{array}{l}\text { Naar rato } \\
\text { van bouwplan }\end{array}$ & Per ha & $\begin{array}{l}\text { Naar rato } \\
\text { van bouwplan }\end{array}$ \\
\hline Aardappel & 25 & 52 & 13 & 18 & 5 \\
\hline Suikerbiet & 20 & 60 & 12 & 10 & 2 \\
\hline Wintertarwe & 20 & 69 & 14 & 1 & 0 \\
\hline Zaaiui & 12,5 & 61 & 8 & 9 & 1 \\
\hline Peen & 12,5 & 82 & 10 & -12 & -2 \\
\hline Totaal & 100 & & 62 & & 8 \\
\hline
\end{tabular}

In Tabel 4.13 is de fosfaatgift weergegeven die volgens het landelijk fosfaatbemestingsadvies ${ }^{26} \mathrm{zou}$ moeten worden toegediend per gewas bij Pw-getal 35 mg $\mathrm{P}_{2} \mathrm{O}_{5} / \mathrm{L}$ en Pw-getal 40 mg $\mathrm{P}_{2} \mathrm{O}_{5} / \mathrm{L}$. Gemiddeld over het bouwplan is die gift lager dan de afvoer en zou een tekort ontstaan op de fosfaatbalans. Om de fosfaattoestand te handhaven, moet meer worden bemest. Indien er geen onvermijdbare verliezen zouden optreden, kan worden volstaan met een gemiddelde fosfaatgift die gelijk is aan de gemiddelde afvoer (evenwichtsbemesting).

Tabel 4.13 Fosfaatgiften volgens het landelijk fosfaatbemestingsadvies voor een voorbeeldbouwplan op centrale zeeklei bij neutrale fosfaattoestand.

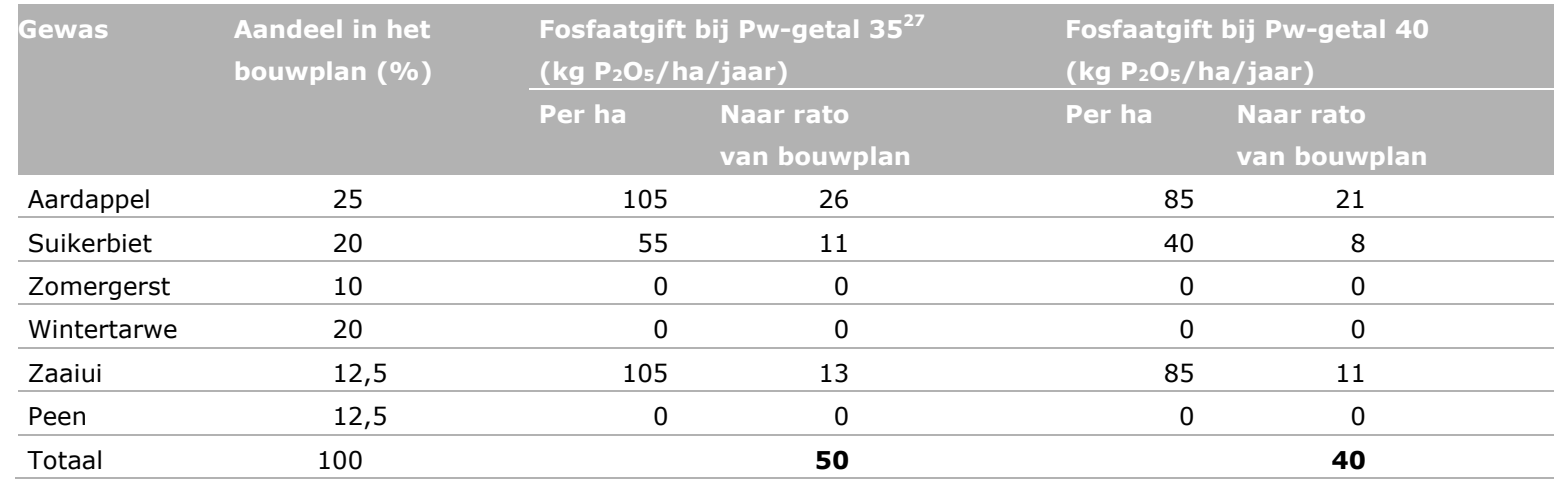

\footnotetext{
${ }^{26}$ http://www.handboekbodemenbemesting.nl/nl/handboekbodemenbemesting/Handeling/Bemesting/Fosfaat/Gewasgerichtadvies/Gewasgericht-advies-voor-volvelds-fosfaatbemesting-op-basis-van-Pw.htm

$27 \mathrm{Pw}$-getal in $\mathrm{mg} \mathrm{P}_{2} \mathrm{O}_{5} / \mathrm{L}$
} 
Een fosfaatgebruiksnorm afgestemd op evenwichtsbemesting levert vanuit landbouwkundig oogpunt een knelpunt op als daarmee de fosfaataanvoer niet toereikend is om de gewasbehoefte te dekken en/of een voldoende hoge fosfaattoestand van de bodem te handhaven. Voor een (economisch) optimale voorziening van fosfaat van land- en tuinbouwgewassen zijn landelijke bemestingsadviezen opgesteld ${ }^{28}$.

Van Dijk et al. (2007) inventariseerden de landbouwkundige en bedrijfseconomische gevolgen van instelling van een fosfaatgebruiksnorm van $60 \mathrm{~kg} \mathrm{P}_{2} \mathrm{O}_{5}$ per ha voor verschillende land- en tuinbouwsectoren en bedrijfstypen. $\mathrm{Zij}$ verwachten dat opbrengstdervingen ten gevolge van een verlaagde fosfaatgebruiksnorm gering zullen zijn en dat het areaal waar problemen kunnen optreden, eveneens beperkt zal zijn, omdat de fosfaattoestand op bouwland in Nederland in het algemeen hoog is. De inkomensderving zal in de meeste gevallen bestaan uit:

- Minder inkomen uit mestafname. Bij verlaging van de fosfaatgebruiksnorm kan er minder dierlijke mest worden geplaatst. Voor de afname van mest ontvangt men geld van de veehouder.

- Toename van kunstmestkosten. Door een lagere aanvoer van dierlijke mest worden naast fosfaat minder andere nutriënten via mest aangevoerd, met name stikstof en kali. Die moet men dan vervangen via kunstmest.

Bij een Pw-getal van $45 \mathrm{mg} \mathrm{P}_{2} \mathrm{O}_{5} / \mathrm{L}$ is er bij een fosfaatgebruiksnorm van $60 \mathrm{~kg} \mathrm{P}_{2} \mathrm{O}_{5}$ per ha op de meeste bedrijven nog geen sprake van een fosfaattekort. Derving door fosfaattekort kan optreden op bedrijven met meer dan 50\% fosfaatbehoeftige gewassen (de naar fosfaatbehoefte ingedeelde gewasgroepen 0 en 1 in het Handboek Bodem en Bemesting), met bovendien een fosfaattoestand lager dan $\mathrm{Pw}$-getal van 35 à $40 \mathrm{mg} \mathrm{P}_{2} \mathrm{O}_{5} / \mathrm{L}$ ). Op de vollegrondsgroentebedrijven is de derving groter dan op de akkerbouwbedrijven. Op de bloembollenbedrijven treden naar verwachting geen opbrengstdervingen op bij de norm van $60 \mathrm{~kg} \mathrm{P}_{2} \mathrm{O}_{5}$ per ha vanwege de relatieve geringe fosfaatbehoefte van de gewassen. Over de fruitteelt en boomteelt hadden de auteurs geen informatie beschikbaar.

De situatie van een hoog aandeel fosfaatbehoeftige gewassen in het bouwplan en een Pw-getal $<35$ à $40 \mathrm{mg} \mathrm{P}_{2} \mathrm{O}_{5} / \mathrm{L}$ komt volgens van Dijk et al. (2007) niet veel voor. Echter, bij strikte evenwichtsbemesting zal het Pw-getal gestaag dalen en zal deze situatie op termijn vaker gaan voorkomen.

Schils et al. (2012) geven aan dat bij verlaging van de fosfaatgebruiksnormen in de richting van evenwichtsbemesting de fosfaattoestand zal dalen en zich zal stabiliseren op gemiddeld lagere niveaus. De mate en de snelheid waarmee dat gebeurt, hangt af van de huidige fosfaattoestand, maar ook van het bufferend vermogen van de grond. Het algemene beeld uit veldproeven is dat evenwichtsbemesting op bouwland vooral bij hogere fosfaattoestanden van de bodem tot een daling van de fosfaattoestand leidt, terwijl bij een lagere fosfaattoestand stabilisatie optreedt. De gewasopbrengsten laten bij evenwichtsbemesting een wisselend beeld zien volgens Schils et al. (2012). Zij verwachten naar verhouding vaker opbrengstdervingen op zandgronden. Op akkerbouwbedrijven is de mate van opbrengstderving afhankelijk van het aandeel fosfaatbehoeftige gewassen in het bouwplan. Op grasland neemt bij evenwichtsbemesting het P-gehalte van het gras doorgaans af.

Volgens van Dijk et al. (2007) ligt de jaarlijkse fosfaatafvoer van grote akkerbouwgewassen als wintertarwe, aardappel (consumptie, zetmeel), snijmaïs, suikerbiet en zaaiuien tussen 50 en $70 \mathrm{~kg}$

\footnotetext{
${ }^{28}$ Voor de akkerbouw staan deze in het Handboek Bodem en Bemesting. Het fosfaatbemestingsadvies voor bouwland is gebaseerd op het Pw-getal van de bodem. Het advies bestaat uit een gewasgericht advies voor het behalen van een economisch optimale opbrengst en uit een bodemgericht advies voor handhaving van de streeftoestand van de bodem en eventuele reparatie daarvan. Bij een te lage fosfaattoestand kan opbrengstderving optreden die niet door een verse fosfaatgift aan het gewas is te compenseren. Het advies is om het $\mathrm{Pw}$-getal te handhaven in het traject $25-45 \mathrm{mg} \mathrm{P}_{2} \mathrm{O}_{5} / \mathrm{L}$ voor zeeklei en zeezand en in 30-45 mg $\mathrm{P}_{2} \mathrm{O}_{5} / \mathrm{L}$ voor dekzand, dalgrond en rivierklei. De hoogte van het gewasgerichte advies hangt af van de fosfaattoestand van de bodem en de gewasbehoefte: bij lagere bodemtoestand is het advies hoger en voor gewassen met een hoge behoefte geldt een hoger advies dan voor gewassen met een lage behoefte. Beide adviezen sturen het fosfaatgebruik passend bij goede landbouwpraktijk. Voor het bodemadvies geldt dat de hoeveelheid fosfaat die op bouwplanniveau wordt afgevoerd weer moet worden aangevoerd om de fosfaattoestand te handhaven plus iets extra voor het onvermijdbare verlies. Als in het bouwplan de gemiddelde fosfaatafvoer hoger is dan het gemiddelde gewasadvies, moet er extra fosfaat worden gegeven boven op het gewasadvies. Als het gewasadvies hoger is dan de afvoer moet het gewasadvies worden gevolgd, maar zal de fosfaattoestand van de bodem toenemen en op een hoger niveau komen. Gewasgerichte en bodemgerichte bemestingsadviezen vormen zo een zelfcorrigerend systeem.
} 
$\mathrm{P}_{2} \mathrm{O}_{5}$ per ha en is deze gemiddeld circa $60 \mathrm{~kg} \mathrm{P} \mathrm{P}_{5}$ per ha per jaar. Hogere afvoeren worden gevonden bij peen, knolselderij en vezelhennep. Bij veel groentegewassen, fruit en bloembolgewassen ligt de afvoer ruim beneden $50 \mathrm{~kg} \mathrm{P}_{2} \mathrm{O}_{5}$ per ha, vaak beneden de $30 \mathrm{~kg} \mathrm{P}_{2} \mathrm{O}_{5}$ per ha.

Schröder en van Dijk (2017) berekenden de fosfaatafvoer voor akkerbouwgewassen en vollegrondsgroenten opnieuw met actuele cijfers over gewasopbrengsten en fosforgehalten. Uit die actualisatie blijkt dat de gemiddelde fosfaatafvoer van een aantal veelvoorkomende Nederlandse bouwplannen in de afgelopen 5-10 jaar nauwelijks is toegenomen. Voor de akkerbouwplannen komt de berekende afvoer 1-5 kg $\mathrm{P}_{2} \mathrm{O}_{5}$ per ha hoger uit en voor de vollegrondsgroentebouwplannen 0-4 kg $\mathrm{P}_{2} \mathrm{O}_{5}$ per ha dan is berekend in 2012 voor het $5^{\mathrm{e}}$ Actieprogramma Nitraatrichtlijn. De fosfaatafvoer varieert van ca. 45 tot $70 \mathrm{~kg} \mathrm{P}_{2} \mathrm{O}_{5}$ per ha per jaar voor de akkerbouwbedrijven en van 20 tot $50 \mathrm{~kg}$ per ha per jaar voor de vollegrondgroentebedrijven. De afvoer hangt sterk af van het bouwplan en de gerealiseerde opbrengsten.

Op de meeste bedrijven is de gebruiksnorm van $60 \mathrm{~kg}$ fosfaat per ha (die thans geldt voor de fosfaattoestand in de categorie Neutraal) genoeg om de jaarlijkse fosfaatafvoer met oogstproducten (inclusief graanstro) te compenseren. Op bedrijven met bovengemiddelde opbrengsten en een hoog aandeel wintertarwe en/of suikerbieten en/of snijmaïs is het echter niet altijd voldoende om de afvoer te compenseren en zal de fosfaattoestand dalen. Op bedrijven met een lagere afvoer daarentegen, zal de fosfaattoestand stijgen. Dit betreft met name de vollegrondsgroentebedrijven.

\subsubsection{Bodemvruchtbaarheid bij evenwichtsbemesting}

De bodemvruchtbaarheid is gemonitord aan de hand van het standaardbodemtesten (P-Al-getal, Pwgetal, $\mathrm{P}-\mathrm{CaCl}_{2}$ ) en additionele bodemtesten (P-ox, P-totaal). De P-CaCl 2 en het Pw-getal zijn een maat voor direct beschikbaar fosfaat (intensiteit) en het P-Al-getal en P-ox-gehalte vormen een maat voor de fosfaatcapaciteit (potentieel voor het gewas beschikbare fosfaatvoorraad). De P-AL-bepaling meet de hoeveelheid zwak gebonden fosfaat, terwijl de P-ox-bepaling daarnaast ook de hoeveelheid sterk gebonden fosfaat bepaalt. P-totaal werd jaarlijks gemonitord te Lelystad. Onderzoeksbodemtesten werden echter zeer incidenteel toegepast bij profielbemonsteringen. De verdeling van residuair meststoffosfaat over andere bodemfracties dan die van reguliere methoden voor bemestingsonderzoek zijn daardoor voor één (Marknesse, Wijster) of twee tijdstippen (Lelystad) bekend. Wijzigingen in de tijd zijn daardoor nog niet te geven.

Bij aanvang van de veldproef te Lelystad waren fosfaattoestanden aangebracht die varieerden van laag tot hoog. Er blijkt een fosfaatoverschot nodig te zijn om die toestanden op het gecreëerde niveau te handhaven (Figuur 4.4). Bij een toestand Pw-getal van $42 \mathrm{mg} \mathrm{P}_{2} \mathrm{O}_{5} / \mathrm{L}$ is dat $11 \mathrm{~kg} \mathrm{P}_{2} \mathrm{O}_{5} / \mathrm{ha}$.

De resultaten van de veldproef te Marknesse wijzen uit dat strikte evenwichtsbemesting de toestand handhaaft op een $\mathrm{Pw}$-getal van $22 \mathrm{mg} \mathrm{P}_{2} \mathrm{O}_{5} / \mathrm{L}$ (i.e. laag). Om een toestand neutraal te handhaven, is meer fosfaat nodig (Figuur 4.3). De veldproef wijst ook uit dat de intensiteitsmaat Pw-getal en $\mathrm{P}-\mathrm{CaCl}$ meer fosfaat vergen om op niveau te blijven dan het P-Al-getal. Er is voor het handhaven van het $\mathrm{P}$-Al-getal voldoende om de afvoer te compenseren.

De veldproef te Wijster wijst eveneens uit dat strikt compenseren van de fosfaatafvoer leidt tot een lage fosfaattoestand. Het handhaven van het P-Al-getal blijkt zelfs mogelijk zonder met fosfaat te bemesten.

De veldproeven op de drie locaties geven met de resultaten van de profielbemonsteringen aan dat meststoffosfaat wordt herverdeeld over fosfaatbodemfracties. Het fosfaat wordt herverdeeld van direct gewas-beschikbare meststoffosfaat naar direct gewas-beschikbaar bodemfosfaat ( $\mathrm{P}-\mathrm{CaCl}_{2}, \mathrm{Pw}$-getal). Het direct gewas-beschikbaar bodemfosfaat wordt herverdeeld over niet direct gewas-beschikbaar bodemfosfaat (P-Al-getal, P-ox). Hoewel P-ox toeneemt met het cumulatieve fosfaatoverschot, wordt niet alle fosfaatoverschot teruggevonden in een toename van P-ox (resultaten profielbemonstering Lelystad). Daarin ligt een aanwijzing besloten dat residuair meststoffosfaat opgeslagen wordt in andere fosfaatbodemfracties dan gesorbeerd fosfaat. Andere bodemfracties kunnen zijn kristallijne vormen van fosfaatmineralen en in het bijzonder in organische verbindingen, behorend tot de organische stof van de bodem. Om inzicht in de verdeling van meststoffosfaat over andere 
bodemfracties te verkrijgen, wordt aanbevolen om een vergelijkbaar onderzoek uit te voeren als bij de grasproef.

Op alle locaties wordt vastgesteld dat jarenlang geen fosfaat toedienen niet leidt tot een wijziging in de fosfaattoestand van de bodem. Jarenlang weet de bodem door het gewas onttrokken fosfaat te bufferen. De incidentele profielbemonsteringen geven wel indicaties dat bodemlagen onder de bouwvoor bijdragen aan het in stand houden van de fosfaattoestand van de bouwvoor. Een kwantificering van deze bijdrage is nog niet mogelijk. Dat vraagt nieuwe bemonstering van de bodemprofielen.

Bij de overgang van een beoordeling van de fosfaattoestand op basis van één methode van grondonderzoek naar een systeem op basis van een intensiteitsmaat en een capaciteitsmaat, wordt op basis van de huidige resultaten van de veeljarige veldproeven verwacht dat het P-Al-getal bij evenwichtsbemesting op niveau gehandhaafd zal kunnen worden. Een intensiteitsmaat als $\mathrm{P}-\mathrm{CaCl}_{2} \mathrm{zal}$ een hogere gift dan compensatie van de afvoer vergen. In welke mate de hoeveelheid fosfaat die nodig is om een bepaalde combinatie van $\mathrm{P}-\mathrm{CaCl}_{2}$ en $\mathrm{P}$-Al-getal te handhaven, is nog niet bekend. Dit vergt aanvullende analyses van beschikbare data in combinatie met fosfaatafvoer. Ook beschikbaarheid van data over jaren is beperkt. Continueren van de veldproeven is noodzakelijk om deze verwachtingen te kunnen toetsen.

Het organische-stofgehalte in de wortelzone kan op peil blijven wanneer fosfaatevenwichtsbemesting wordt uitgevoerd. De keuze van de mestsoort en het bouwplan bepalen in sterke mate de hoeveelheid effectieve organische stof die wordt aangevoerd.

\subsection{Bodemvocht}

Bodemvochtmetingen zijn uitgevoerd gedurende zes winterseizoenen (2003/2004, 2004/2005, 2006/2007, 2008/2009, 2009/2010 en 2010/2011) op drie locaties (Lelystad, Marknesse, Wijster). Bodemvocht werd bemonsterd met behulp van kunstwortels. Bij Lelystad en Marknesse werd op 35 en $75 \mathrm{~cm}$ bemonsterd, bij Wijster op 35 en aanvankelijk ook op $155 \mathrm{~cm}$. De bemonstering op $155 \mathrm{~cm}$ werd gestaakt wegens de zeer lage concentraties in combinatie met de hoge eisen aan de bemonsteringstechniek door de aanwezigheid van een keileemlaag in de ondergrond.

Op alle locaties is het fosfaat in het bodemvocht nagenoeg volledig aanwezig in de vorm van orthofosfaat. De bijdrage van organisch fosfaat en/of colloïdaal fosfaat is verwaarloosbaar. Op Wijster en Marknesse, gronden met een lage/neutrale fosfaatstatus, zijn de fosfaatconcentraties in het bodemvocht van de bouwvoor zeer laag $(0,01-0,1 \mathrm{mg} / \mathrm{l})$. Er is geen relatie tussen fosfaatconcentratie in het bodemvocht en de mate van fosfaatbemesting $(0-240 \mathrm{~kg} / \mathrm{ha})$. Op grotere diepte $(75-155 \mathrm{~cm})$ zijn de fosfaatconcentraties onder deze percelen nauwelijks detecteerbaar $(<0,01 \mathrm{mg} / \mathrm{l})$ en eveneens onafhankelijk van bemestingsniveau. Op de zavelgrond in Lelystad is wel een significante relatie tussen effect van bemesting op fosfaatconcentraties in het bodemvocht in de bouwvoor aangetoond. Echter, ook hier zijn de fosfaatconcentraties op $75 \mathrm{~cm}$ diepte zeer laag en onafhankelijk van het bemestingsniveau en de fosfaattoestand van de objecten.

Op Lelystad is aangetoond dat fosfaatconcentraties in het bodemvocht van de bouwvoor zijn gedaald

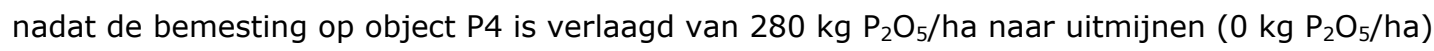

(Figuur 4.21). Op de andere veldproeven zijn geen aanwijzingen dat de fosfaatconcentraties in de periode tussen 2003 en 2011 zijn veranderd. Hierbij wordt opgemerkt dat de concentraties veelal zeer laag zijn, bodemvochtmetingen normaliter een sterke variatie tonen door invloed van weersomstandigheden en dat er slechts in vijf seizoenen gemonitord is. 
Tabel 4.14 Gemiddelde concentraties in $\mathrm{mg} P / L$ aan totaal-P en ortho-fosfaat in bodemvocht van bodemlagen op 35, 75 en $155 \mathrm{~cm}$ met hun standaardafwijking (stdev) en aantal waarnemingen ( $n$ ) voor de drie veldproeven te Lelystad, Marknesse en Wijster. De gemiddelden berusten op monitoring gedurende de seizoenen 2003/2004, 2004/2005, 2006/2007, 2008/2009 en 2010/2011.

\begin{tabular}{|c|c|c|c|c|c|c|c|c|}
\hline \multirow[t]{2}{*}{ Proef } & \multirow[t]{2}{*}{ Object en dosering ( $\mathrm{kg} \mathrm{P}_{2} \mathrm{O}_{5} / \mathrm{ha}$ ) } & \multirow[t]{2}{*}{ Diepte, cm } & \multicolumn{3}{|c|}{ Totaal-P } & \multicolumn{3}{|c|}{ Ortho-P } \\
\hline & & & Gem. & stdev & n & Gem. & stdev & n \\
\hline \multirow[t]{7}{*}{ Lelystad } & $\mathrm{P} 1(0)$ & 35 & 0,02 & 0,03 & 106 & 0,01 & 0,01 & 99 \\
\hline & $\mathrm{P} 2(70)$ & 35 & 0,16 & 0,29 & 103 & 0,14 & 0,14 & 87 \\
\hline & & 75 & 0,01 & 0,02 & 113 & 0,00 & 0,00 & 107 \\
\hline & & 75 & 0,01 & 0,02 & 123 & 0,01 & 0,01 & 116 \\
\hline & $\mathrm{P} 4(280)$ & 35 & 2,42 & 4,13 & 113 & 2,41 & 2,41 & 100 \\
\hline & & 75 & 0,02 & 0,04 & 125 & 0,03 & 0,03 & 116 \\
\hline & P4 uitmijnen & 35 & 0,88 & 0,50 & 48 & 0,74 & 0,74 & 41 \\
\hline \multirow{8}{*}{ Marknesse } & 80 & 35 & 0,03 & 0,05 & 54 & 0,02 & 0,02 & 47 \\
\hline & & 75 & 0,01 & 0,02 & 62 & 0,01 & 0,01 & 60 \\
\hline & 160 & 35 & 0,01 & 0,03 & 56 & 0,02 & 0,02 & 50 \\
\hline & & 75 & 0,02 & 0,03 & 59 & 0,01 & 0,01 & 56 \\
\hline & 240 & 35 & 0,04 & 0,09 & 60 & 0,04 & 0,04 & 50 \\
\hline & & 75 & 0,01 & 0,02 & 50 & 0,01 & 0,01 & 43 \\
\hline & M & 35 & 0,02 & 0,04 & 60 & 0,01 & 0,01 & 56 \\
\hline & & 75 & 0,02 & 0,07 & 61 & 0,01 & 0,01 & 56 \\
\hline \multirow{14}{*}{ Wijster } & Natuurfosfaat, 180 & 35 & 0,04 & 0,04 & 16 & 0,02 & 0,02 & 12 \\
\hline & & 155 & 0,01 & 0,03 & 21 & 0,01 & 0,01 & 20 \\
\hline & Rhenania, uitmijnen, 180 & 35 & 0,05 & 0,06 & 23 & 0,02 & 0,02 & 18 \\
\hline & & 155 & 0,01 & 0,02 & 25 & 0,00 & 0,00 & 23 \\
\hline & Slakkenmeel, 180 & 35 & 0,08 & 0,05 & 13 & 0,06 & 0,06 & 14 \\
\hline & & 155 & 0,02 & 0,03 & 21 & 0,01 & 0,01 & 21 \\
\hline & Superfosfaat, 45 & 35 & 0,10 & 0,07 & 11 & 0,05 & 0,05 & 10 \\
\hline & & 155 & 0,04 & 0,03 & 27 & 0,01 & 0,01 & 21 \\
\hline & Superfosfaat, 90 & 35 & 0,10 & 0,07 & 11 & 0,05 & 0,05 & 10 \\
\hline & & 155 & 0,04 & 0,03 & 27 & 0,01 & 0,01 & 21 \\
\hline & Superfosfaat, 180 & 35 & 0,15 & 0,33 & 17 & 0,12 & 0,12 & 17 \\
\hline & & 155 & 0,01 & 0,02 & 24 & 0,00 & 0,00 & 22 \\
\hline & Superfosfaat, 240 & 35 & 0,10 & 0,06 & 16 & 0,06 & 0,06 & 12 \\
\hline & & 155 & 0,02 & 0,03 & 20 & 0,01 & 0,01 & 16 \\
\hline
\end{tabular}




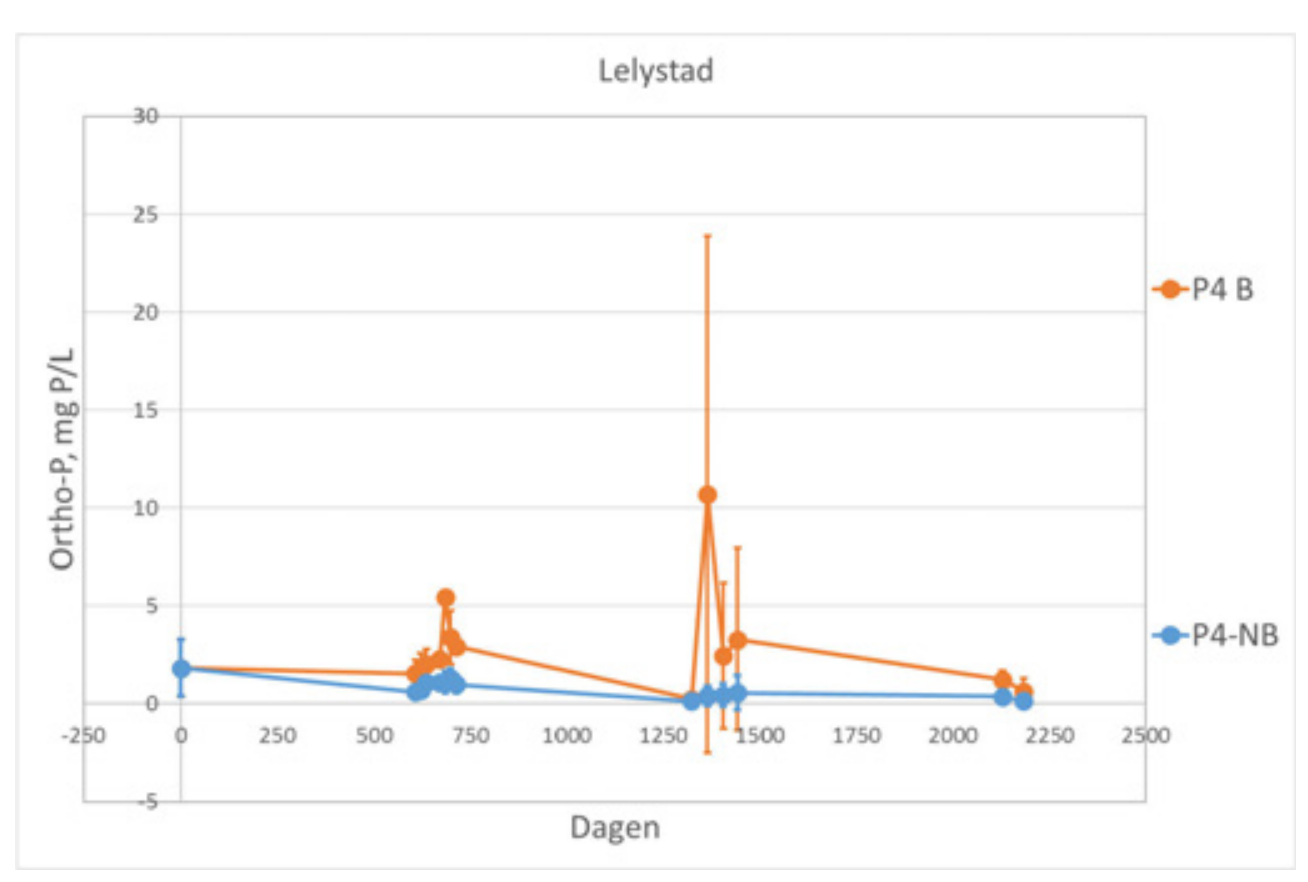

Figuur 4.21 Opgelost fosfaat (Ortho-P) bemonsterd in $\mathrm{mg} P / L$ in de bodemlaag op $35 \mathrm{~cm}$ te Lelystad voor de behandeling P4. Vanaf 2005 (O dagen) is deze behandeling opgesplitst in een deel dat jaarlijks $280 \mathrm{~kg} \mathrm{P}_{2} \mathrm{O}_{5} /$ ha krijgt ( $\mathrm{P4} \mathrm{B}$ ) en een deel dat niet meer met fosfaat bemest wordt (P4-NB).

\subsection{Antwoorden op de vragen}

\subsubsection{Leidt toepassing van een gebruiksnorm voor fosfaat, afgestemd op evenwichtsbemesting, tot een afname van de gewasopbrengst en kwaliteit en is er een moment waarop deze afname stabiliseert?}

Een reductie van de fosfaatbemesting heeft een traag effect op de reactie van het gewas. Er is daardoor geen aanwijzing dat verlaging van de fosfaatgift direct een risico geeft op een aanzienlijke derving van opbrengst en kwaliteit. Zelfs het onthouden van enige vorm van fosfaatbemesting leidt in de periode 2000-2016 niet tot een misoogst voor akkerbouwgewassen.

Op grasland leidt evenwichtsbemesting op alle locaties tot een lager P-gehalte in het gewas en op zand en veen ook tot lagere opbrengsten ( $700 \mathrm{~kg} \mathrm{DS} / \mathrm{ha} / \mathrm{jaar}$ ) ten opzichte van overschotbemesting. Er is geen negatieve ontwikkeling van opbrengsten of kwaliteit in de loop van de tijd vastgesteld. Wel wordt verwacht dat bij evenwichtsbemesting de opbrengst en kwaliteit in de tijd verder zullen gaan dalen gezien de dalende fosfaattoestanden (zie bij vraag 2, paragraaf 5.2.2).

Evenwichtsbemesting leidt, in vergelijking tot overschotbemesting, bij fosfaatbehoeftige akkerbouwgewassen (zoals aardappel) tot lagere opbrengsten. Bij gewassen met een lage fosfaatbehoefte (zoals suikerbieten en graan) worden lagere opbrengsten vastgesteld bij gronden met fosfaattoestand laag, maar niet bij fosfaattoestand neutraal of hoog. Bij deze fosfaattoestanden is er geen negatief effect van evenwichtsbemesting op de opbrengst. Door in de vruchtwisseling de fosfaatbemesting vooral bij gewassen met een hoge fosfaatbehoefte te geven, kan op bedrijfsniveau evenwichtsbemesting gerealiseerd worden met geen of een beperkt negatief effect op de opbrengst. Dit is echter wel lastig te realiseren op bedrijven die sterk gespecialiseerd zijn in een of enkele (fosfaatbehoeftige) gewassen. 


\subsubsection{Leidt een veeljarige toepassing van een gebruiksnorm voor fosfaat, afgestemd op evenwichtsbemesting, tot een vermindering van de fosfaatbeschikbaarheid of het organische-stofgehalte?}

Het is niet het gewas dat het eerst reageert op opgelegde behandelingen, het is de fosfaattoestand, uitgedrukt in de standaardbodemtesten Pw-getal, $\mathrm{P}$-Al-getal en $\mathrm{P}-\mathrm{CaCl}_{2}$, die als eerste reageert op evenwichtsbemesting in vergelijking met hogere fosfaataanvoeren. Grondonderzoek is daardoor een middel om risico op derving van opbrengst en kwaliteit te beheersen.

Bij grasland werden aanwijzingen gevonden dat evenwichtsbemesting leidt tot een lager P-Al-getal op zandgrond in de bodemlaag $0-10 \mathrm{~cm}$. Dat werd niet gevonden op kleigrond en op veengrond. Bij grasland hebben opgelegde fosfaatbehandelingen geen invloed op de bodemlaag $20-30 \mathrm{~cm}$. Op bouwland werden aanwijzingen gevonden dat evenwichtsbemesting leidt tot lagere waarden voor de intensiteit waarmee de bodem fosfaat aan het gewas levert, te weten $\mathrm{P}-\mathrm{CaCl}_{2}$ en $\mathrm{Pw}$-getal, maar niet voor de capaciteit P-Al-getal. Bij bouwland worden de effecten van fosfaatoverschotten (negatief, positief) ook in diepere bodemlagen (tot ca. $60 \mathrm{~cm}$ ) vastgesteld.

Louter focussen op deze standaardbodemtesten kent echter een risico, omdat de verdeling van fosfaat over fosfaatbodemfracties grotere verschuivingen te zien geeft dan tot uitdrukking komt in deze testen. Bij evenwichtsbemesting op zowel grasland als bouwland neemt het relatieve aandeel van slecht voor het gewas beschikbare bodemfracties toe. Absoluut gezien nemen bij grasland beide bodemfracties af. Evenwichtsbemesting leidt dus op termijn tot een andere verdeling tussen fosfaatbodemfracties en de mate waarin de bodem in staat is om direct fosfaat aan het gewas te leveren (intensiteit) en op langere termijn fosfaat na te leveren (capaciteit). Omdat de direct voor het gewas beschikbare fosfaat aan het afnemen is, wordt verwacht dat dit op een gegeven moment leidt tot dalende opbrengst en kwaliteit van de gewassen.

Bij grasland werden aanwijzingen gevonden dat een deel van het fosfaat in de bodem opgeslagen wordt in organisch fosfaat (P-org). Voor bouwland is onderzoek naar opslag van fosfaat in organische stof nog niet uitgevoerd. Uitzondering vormt de profielbemonstering in 2009 te Lelystad, waarbij vastgesteld werd dat er geen verschil in gehalten aan P-org was tussen de behandelingen.

De hoeveelheid fosfaat die extra nodig is op grasland om de toestand als P-Al-getal te handhaven, is circa $7 \mathrm{~kg} \mathrm{P} \mathrm{O}_{5} / \mathrm{ha} /$ jaar (Salm e.a., 2017). De fosfaattoestanden bij evenwichtsbemesting liggen in het bereik laag - neutraal. Indicatieve waarden voor het in stand houden van het Pw-getal of P-Al-getal op bouwland bij lage fosfaattoestanden zijn 10-20 kg P $\mathrm{O}_{5} / \mathrm{ha} / \mathrm{jaar}$ en bij toestand neutraal $\sim 30 \mathrm{~kg}$ $\mathrm{P}_{2} \mathrm{O}_{5} /$ ha/jaar.

\subsubsection{Leidt een veeljarige toepassing van een gebruiksnorm voor fosfaat, afgestemd op evenwichtsbemesting, tot een vermindering van de fosfaatuitspoeling?}

Verliezen door fosfaatuitspoeling kunnen onder andere geschat worden door metingen van fosfaat in bodemvocht. Bij de grasproef werden in de periode 1997-2011 en bij de veldproeven op bouwland gedurende zes winterseizoenen vanaf 2003 tot en met 2011 metingen in bodemvocht uitgevoerd. Uit de graszode of bouwvoor lekt altijd fosfaat. De fosfaattoestanden en de bodemchemische eigenschappen onder deze bodemlagen (inclusief (preferente) stroombanen) bepalen of er risico is op uitspoeling.

Bij de grasproef zijn jaargemiddelde fosfaatverliezen door een combinatie van meetgegevens en modelberekeningen verkend. De jaargemiddelde fosfaatverliezen blijken op zandgrond aanzienlijk hoger te zijn dan op zeeklei en veengrond. Jaargemiddelde fosfaatverliezen door uitspoeling variëren van $1,0 \mathrm{~kg} \mathrm{P}_{2} \mathrm{O}_{5} \mathrm{ha}^{-1} \mathrm{j}^{-1}$ op Lelystad (zeeklei) tot $11,4 \mathrm{~kg} \mathrm{P}_{2} \mathrm{O}_{5} \mathrm{ha}^{-1} \mathrm{j}^{-1}$ op Heino (zand). Relatief hoge uitspoelingsverliezen worden ook gevonden in percelen met een hoge laterale drainage. Op Zegveld (veen) is bijvoorbeeld de concentratie onder in de wortelzone relatief laag $(0,3 \mathrm{mg} / \mathrm{L}$, Figuur 3.20$)$, maar is de uitspoeling vergelijkbaar met die op Soerendonk (zand). Het neerslagoverschot heeft eveneens een grote invloed op de hoeveelheid fosfaat die uitspoelt. In droge jaren $(1997,2003)$ is de 
uitspoeling op alle locaties gering en in sommige gevallen zelfs negatief. In natte jaren (1998, 2000, 2002) is de mate van fosfaatuitspoeling aanzienlijk hoger (Van Middelkoop et al., 2007). Fosfaatverliezen vanuit de wortelzone zijn gelijk bij evenwichtsbemesting en hogere fosfaatbemestingen, met uitzondering van veengronden met een hoge laterale uitspoeling.

Bij de veldproeven op bouwland zijn resultaten van een studie beschikbaar waarbij voor de locaties Marknesse en Wijster oriënterend onderzoek is uitgevoerd naar nalevering van fosfaat uit verschillende bodemfracties bij uitmijnen (Salm en Schoumans, 2011). Uitspoelingsverliezen op deze locaties zullen evenwel laag zijn, omdat weinig opgelost fosfor in bodemvocht werd gevonden en een effect van opgelegd fosfaatmanagement niet werd gevonden. Dit is anders bij de veldproef te Lelystad, waar vastgesteld werd dat de fosforconcentraties in het bodemvocht toenemen met toename van de fosfaattoestand door accumulerende fosfaatoverschotten. Omdat er voldoende bufferend vermogen is in de ondergrond, is de kans dat extra $\mathrm{P}$ uitspoelt uit bodemlagen dieper dan $75 \mathrm{~cm}$ op de drie locaties nagenoeg nul. Berekeningen met een nutriëntenemissiemodel zijn bij deze veldproef of andere bouwlandproeven niet uitgevoerd.

Vergelijking van de fosfaatconcentraties in het bodemvocht van de grasproef en bouwlandproef laten zien dat er grote verschillen zijn tussen beide. Op de grasproef bestaat het fosfaat in het bodemvocht grotendeels uit organisch/colloïdaal fosfaat, terwijl op de bouwlandproeven uitsluitend ortho-P wordt gemeten. Hierdoor zijn de gemiddelde totale fosfaatconcentraties in de grasproef aanzienlijk hoger dan op de bouwlandproef. Deze verschillen worden vermoedelijk veroorzaakt door een verschil in monstername op grasproef (centrifugeren van veldvochtige grond) en bouwlandproef (opzuigen d.m.v. kunstwortels). 


\section{$5 \quad$ Evaluatie en implicaties van resultaten}

\section{$5.1 \quad$ Inleiding}

In paragraaf 1.3 zijn de vragen vermeld die voortkomen uit de kennisbehoefte bij de ontwikkeling van de actieplannen voor de Nitraatrichtlijn, die met deze veeljarige fosfaatproeven op grasland en bouwland beantwoord kunnen worden. Deze vragen worden hieronder herhaald:

1. Leidt toepassing van een gebruiksnorm voor fosfaat, afgestemd op evenwichtsbemesting, tot een afname van de gewasopbrengst en kwaliteit en is er een moment waarop deze afname stabiliseert?

2. Leidt een veeljarige toepassing van een gebruiksnorm voor fosfaat, afgestemd op evenwichtsbemesting, tot een vermindering van de fosfaatbeschikbaarheid of het organischestofgehalte?

3. Leidt een veeljarige toepassing van een gebruiksnorm voor fosfaat, afgestemd op evenwichtsbemesting, tot een vermindering van de fosfaatuitspoeling?

In paragraaf 5.2 worden de vragen beantwoord met de kennis die nu beschikbaar is. De resultaten op grasland en bouwland verschillen op essentiële onderdelen van elkaar. Er zal, indien nodig, onderscheid gemaakt worden tussen de beide vormen van landgebruik. In paragraaf 5.3 wordt aangegeven hoe de kennis uit deze proeven is toegepast in andere projecten die van belang zijn voor het opstellen van actieplannen voor de Nitraatrichtlijn. In paragraaf 5.4 wordt beschreven hoe nadere analyse van beschikbare data en voortzetting van de huidige proeven kunnen bijdragen aan een scherper antwoord op bovenstaande vragen. Daarnaast wordt ook aangegeven in hoeverre vragen vanuit de Kaderrichtlijn Water beantwoord kunnen worden.

\subsection{Toepassing van kennis uit proeven in andere projecten}

De kennis die verzameld is in de proeven is in de loop van de jaren toegepast in andere projecten. Hieronder volgt een overzicht met enige referenties. Een uitgebreidere weergave van de inhoud van de projecten is opgenomen in Bijlage 1.

\section{Evaluaties Meststoffenwet}

- Het achtergronddocument bij de Evaluatie Meststoffenwet in 2004 heeft gebruikgemaakt van gegevens van reeksen van veeljarige veldproeven, waaronder die welke op bouwland waren aangelegd (Velthof, 2004). Veranderingen in bemesting hebben een traag effect op de fosfaattoestand van de bodem. Het duurt jaren voordat de fosfaattoestand van een bodem stabiel is bij een jaarlijks overschot van $20 \mathrm{~kg} \mathrm{P}_{2} \mathrm{O}_{5}$ per ha per jaar. Het onthouden van fosfaatbemesting leidt niet tot een directe en snelle daling van de fosfaattoestand.

- Gegevens van de profielbemonstering werden gebruikt door Willems et al. (2004).

- Gegevens van de veeljarige veldproeven op grasland en bouwland werden toegepast bij de Evaluatie Meststoffenwet in 2012 (Schils et al., 2012). Fosfaattoestanden daalden bij fosfaatevenwichtsbemesting op grasland op zand tot een P-Al-getal van 25 tot $30 \mathrm{mg} \mathrm{P}_{2} \mathrm{O}_{5} / \mathrm{L}$, terwijl ze op veen en klei stabiel bleven. Op bouwland zijn de resultaten niet eenduidig. In systeemonderzoek daalde de fosfaattoestand bij evenwichtsbemesting. In veldproeven bleef de fosfaattoestand daarentegen stabiel bij evenwichtsbemesting. In de veldproeven treedt bij evenwichtsbemesting stabilisatie op bij een Pw-getal van 15 tot $20 \mathrm{mg} \mathrm{P}_{2} \mathrm{O}_{5} / \mathrm{L}$.

- Bij de behandeling van effecten van het fosfaatgebruiksnormenstelsel op opbrengst en kwaliteit in de Evaluatie Meststoffenwet van 2016 werden de generieke bevindingen van de veeljarige veldproeven toegepast (Velthof et al., 2017). De resultaten van de veeljarige veldproeven werden geplaatst tegen de bevindingen in de praktijk. De resultaten (tot 2014) zoals beschreven in dit 
syntheserapport werden generiek beschreven en leidde tot de bevinding dat veel fosfaat wordt nageleverd. Over langere tijd, enige tientallen jaren, blijft de fosfaattoestand op een afdoende peil.

Andere deskstudy's

- Salm en Schoumans (2011) hebben door middel van een modelstudie de langetermijneffecten van verminderde fosfaatgiften onderzocht (zie ook paragraaf 5.2.3). Het resultaat van de studie wijst uit dat het langetermijngedrag bij fosfaatontlading van de bodem (uitmijnen) redelijk gesimuleerd kan worden bij een juiste instelling van de lange-termijn-desorptieparameters. Geconcludeerd werd dat op de middellange termijn (5-10 jaar) bij dalende en negatieve fosfaatoverschotten het gedrag van fosfaat in de bodem redelijk te beschrijven is met de huidige procesformulering in STONE en de in deze studie afgeleide desorptiesnelheden. Om op nationale schaal voorspellingen te kunnen uitvoeren, is echter wel meer inzicht nodig in de omvang van de lange-termijn-desorptieparameters in relatie tot bodemtype en verzadigingsgraad.

- Gegevens van de grasproef werden door Salm et al. (2016) gebruikt om een vijftal modellen onderling te vergelijken. Daarvoor werden onder andere gegevens van de grasproef gebruikt. In het algemeen simuleren de onderling vergeleken modellen de opbouw van de fosfaattoestand bij een fosfaatoverschot redelijk tot goed. Lagere aanvoer van fosfaat dan de fosfaatafvoer werd minder goed gesimuleerd. Simulaties voor de zandgrond waren beter dan die voor de kleigrond en veen. De basisgegevens van de grasproef reiken echter een verantwoord handvat aan om dergelijke modelstudies uit te voeren.

- De deskstudy van Dekker en Postma (2008) onderzocht of de verlaging van de fosfaatgiften in de uitvoeringspraktijk op akkerbouw naar fosfaatgebruiksnormen opgevangen kan worden door verhoging van de efficiëntie van de fosfaatbemesting. In deze deskstudy werd, op basis van de veldproefgegevens te Lelystad, ervan uitgegaan dat voor het handhaven van een bepaalde toestand, gemiddeld over het bedrijf de fosfaatafvoer moet worden gecompenseerd plus ongeveer $20 \mathrm{~kg}$ $\mathrm{P}_{2} \mathrm{O}_{5} /$ ha voor de 'onvermijdbare verliezen'.

- Gegevens van de veeljarige veldproeven op bouwland werden door Van Dijk et al. (2007) gebruikt bij hun CDM-studie (CDM: Commissie Deskundigen Meststoffenwet) over aanscherping van fosfaatgebruiksnormen op bouwland bij akker- en tuinbouwgewassen in het kader van een verkenning van noodzaak en mogelijkheden tot differentiatie. Gevolgen van aanscherping van fosfaatgebruiksnormen werden in werkelijkheid als gering aangemerkt. Bedrijven met meer dan $50 \%$ fosfaatbehoeftige gewassen (gewasgroep 0 en 1 van de adviesbasis) kunnen derving ondervinden bij een Pw-getal lager dan 35 of 40 mg $\mathrm{P}_{2} \mathrm{O}_{5} / \mathrm{L}$. Deze bedrijven werden aangemerkt als baat hebbend bij differentiatie.

- Bij een vergelijkbare CDM-studie over aanscherping van fosfaatgebruiksnormen op grasland werden onder andere de gegevens van de grasproef toegepast (Aarts et al., 2008). Eén conclusie, die mede gebaseerd is op de resultaten van de grasproef, is dat de eerste tien jaar na invoering van evenwichtsbemesting een negatieve invloed hebben op de opbrengst, maar geen invloed op de veegezondheid. Gewezen werd op de traag verlopende bodemprocessen. Lange reeksen werden nodig gevonden om betrouwbaardere beelden te verkrijgen.

- Voor actualisaties van P-afvoercijfers werden ook meetgegevens van de gras- en bouwlandproeven gebruikt (Ehlert et al., 2006; Ehlert et al., 2009).

\subsection{Toekomstige bijdrage van dit onderzoek aan beantwoording kennisvragen}

\subsubsection{Proeven lopen vooruit op praktijk}

De veldproeven geven inzicht in de feitelijke gevolgen van evenwichtsbemesting op lange termijn. Deze informatie is niet beschikbaar uit ander Nederlands landbouwkundig onderzoek. De veeljarige veldproeven zijn ruim voordat het stelsel van gebruiksnormen in 2006 van kracht werd, aangelegd. Effecten van evenwichtsbemesting op opbrengst, kwaliteit en bodemvruchtbaarheid zijn daardoor minimaal tien jaar eerder in onderzoek genomen dan in de landbouwpraktijk tot expressie kunnen komen. De veldproeven signaleren daardoor tijdig mogelijke - nadelige - effecten van het beleid over 
fosfaatgebruik. Beleid kan daardoor tijdig met maatregelen bijsturen voordat de landbouwpraktijk daar effectief (grote) negatieve gevolgen van ondervindt.

\subsubsection{Beantwoording van vragen door verdere analyse van reeds beschikbare data}

Bij de grasproef zijn gegevens van trends beschikbaar van standaardbodemtesten en onderzoeksmethoden, bij de veldproeven op bouwland zijn die trends beperkt beschikbaar en/of nog in opbouw, onder andere door aanvullende analyses in gearchiveerde grondmonsters uit te voeren. Een deel van de gegevens wacht nog op bewerking. Aanvullend onderzoek aan gearchiveerde grondmonsters kunnen de trends zichtbaar maken en kan antwoord geven op de vraag of de verdeling van fosfaat over fosfaatbodemfracties verandert. Aanvullend onderzoek ondersteunt mogelijke wijzigingen bij overgang van een één-parametersysteem (Pw-getal of P-Al-getal) bij fosfaatgebruiksnormen naar een twee-parametersysteem (bv. P- $\mathrm{CaCl}_{2}$ en P-Al-getal).

De bevindingen gebaseerd op resultaten van de veldproeven zijn in de periode 2000-2016 jaarlijks via infobladen en vakbladartikelen uitgedragen naar de landbouwpraktijk (zie literatuur ${ }^{29}$ ). De vragen uit de praktijk over effecten van evenwichtsbemesting blijven komen. Het blijkt daarbij keer op keer dat boeren zich niet bewust zijn van de risico's van fosfaatuitspoeling en het belang van evenwichtsbemesting hierin. Het uitdragen van de resultaten van de veldproeven blijft actueel om bewustwording en acceptatie in de landbouwpraktijk te creëren over de effecten van evenwichtsbemesting en te onderhouden. Het gaat niet alleen om ontbrekende kennis, maar ook om continueren van kennisoverdracht.

Validatie van modellen behoort niet tot de uitvoering van het project waar dit syntheserapport betrekking op heeft. Zo zijn door toepassing van meetgegevens vermeld in dit syntheserapport in andere projecten kengetallen verkregen voor de hoeveelheid fosfaat die uitspoelt (bv. Salm en Schoumans, 2011). Ook werden modelmatige verkenningen uitgevoerd welk effect veeljarig verminderd fosfaatgebruik heeft op fosfaatuitspoeling. Dergelijke modelmatige verkenningen zijn nog niet uitgevoerd met meetgegevens van de veldproeven op bouwland. De data van de veeljarige veldproeven kunnen echter gebruikt worden in de validatie van modellen die fosfaatprocessen in de bodem simuleren.

\subsubsection{Beantwoording van vragen door voortzetting van de veldproeven}

\subsubsection{Effect op gewasopbrengst en -kwaliteit}

Voortzetting van de veldproeven geeft gedetailleerder uitsluitsel over veeljarige effecten van fosfaatmanagement op opbrengst en kwaliteit. In de graslandproeven verwachten we in de komende jaren te kunnen bepalen hoe de geconstateerde afname in P-bodemvoorraad zich gaat vertalen in opbrengst- en kwaliteitsverlies. In de bouwlandproeven verwachten we te kunnen bepalen hoe de geconstateerde afname in P-bodemvoorraad in de bouwvoor doorwerkt naar verlies van opbrengst en kwaliteit en doorwerkt naar de P-bodemvoorraad van onder de bouwvoor gelegen bodemlagen. De vraag daarbij is of onder de bouwvoor gelegen bodemlagen kunnen bijdragen aan het in stand houden van opbrengst en kwaliteit. De verkregen kennis over opbrengst en kwaliteit ondersteunt informatie die uit ander landbouwkundig onderzoek wordt verkregen.

\subsubsection{Effect op fosfaatbodemfracties: wel en niet direct gewas-beschikbaar}

De bevinding dat standaardbodemtesten de veranderingen in de fosfaatbodemfracties niet volledig weergeven en volgen, geeft aan de veeljarige veldproeven een unieke betekenis en functie. Vastgesteld wordt dat effecten van evenwichtsbemesting eerder tot uitdrukking komen in veranderingen in de bodem dan in veranderingen van de gewasreactie op fosfaatbemesting en fosfaattoestand. Vastgesteld wordt dat deze veranderingen in de bodem traag verlopen, maar wel leiden tot een steeds voortschrijdende vermindering van die fosfaatbodemfracties die juist direct

\footnotetext{
${ }^{29}$ Naast bronvermeldingen van in dit syntheserapport geciteerde publicaties, geeft Literatuur ook een overzicht van publicaties die gebruik hebben gemaakt van gegevens van de veeljarige veldproeven.
} 
gewas-beschikbaar zijn. Wanneer deze afname zich daadwerkelijk zal manifesteren in een afname van opbrengst of kwaliteit, is nog niet bekend (zie paragraaf hierboven).

De afname van deze voor het gewas belangrijke fosfaatbodemfracties zal naar verwachting gaan bepalen wat het effect is van fosfaatevenwichtsbemesting. Belangrijk wordt hoe deze direct gewasbeschikbare fosfaatbodemfracties (bv. $\mathrm{P}-\mathrm{CaCl}_{2}$ en $\mathrm{Pw}$-getal) gebufferd worden door nalevering van fosfaat uit niet direct gewas-beschikbare fosfaatbodemfracties (bv. P-Al-getal en P-ox).

Een vraag voor komende jaren is welke variatie gaat optreden in $\mathrm{P}-\mathrm{CaCl}_{2}$ en in $\mathrm{P}$-Al-getal en hoe zich dat verhoudt indien overgegaan wordt naar een beoordeling van de fosfaattoestand op basis van $\mathrm{P}-\mathrm{CaCl}_{2}$ en P-Al-getal. Aandachtspunt hierbij is dat bij geen van de veldproeven over de looptijd van de veldproef een volledige set data van zowel $\mathrm{P}-\mathrm{CaCl}_{2}$ als $\mathrm{P}-\mathrm{Al}$-getal beschikbaar is. Gearchiveerde grondmonsters wachten nog op analyse. De veldproeven reiken dus hier een handvat aan om dit aspect te kunnen onderzoeken.

Voortzetting van de veldproeven draagt bij aan het antwoord op de vraag over het effect van evenwichtsbemesting op de verdeling van fosfaat over fosfaatbodemfracties en leidt daardoor tot een gerichter en beter onderbouwd antwoord op deze vraag.

\subsubsection{Hoeveelheid fosfaat nodig om fosfaattoestand te handhaven}

De veldproeven geven richting aan de orde van grootte voor de hoeveelheid fosfaat die nodig is om boven de afvoer te worden gegeven om een bepaalde fosfaattoestand te handhaven (landbouwkundig onvermijdbaar fosfaatverlies). Het benodigde fosfaatoverschot wordt voortdurend verdeeld over direct gewas-beschikbare en tot niet voor het gewas-beschikbare bodemfracties. Bij strikte

evenwichtsbemesting leidt dit tot achteruitgang van direct gewas-beschikbare bodemfracties zoals die met $\mathrm{P}-\mathrm{CaCl}_{2}$ en $\mathrm{Pw}$-getal worden bepaald, en eveneens tot achteruitgang in de niet direct gewasbeschikbare fracties als P-Al-getal (grasland), P-oxalaat en P-totaal. Hoe het landbouwkundig fosfaatoverschot afhangt van $\mathrm{P}-\mathrm{CaCl}_{2}$ en $\mathrm{P}$-Al-getal is niet bekend. Deze kennisleemte kan met gegevens van veeljarige trends van de veeljarige veldproeven worden ingevuld. Daarbij is ook kennis nodig over veranderingen in fosfaatfracties die niet met standaardbodemtesten worden bepaald. De informatie over deze fosfaatfracties is beperkt aanwezig bij de grasproef (vooral eerste drie en laatste drie jaren) en nog beperkter bij de veldproeven op bouwland (incidenteel). Het vaker uitvoeren van deze testen is dus gewenst.

\subsubsection{Fosfaat onder de bouwvoor op bouwland}

Fosfaatmanagement op bouwland bepaalt ook de fosfaattoestand en fosfaatbodemfracties in bodemlagen onder de bouwvoor. Bij de drie locaties werd in 2002 een profielbemonstering uitgevoerd, bij de locatie Lelystad werd in 2009 de profielbemonstering herhaald. De keuze voor deze locatie berust op de grotere dynamiek van fosfaat in de bodem t.o.v. van de locaties Marknesse en Wijster. Het verdient aanbeveling om deze profielbemonstering op alle locaties te herhalen, juist om de effecten van opgelegd fosfaatmanagement op bouwvoor en ondergrond vast te stellen na respectievelijk 9 jaar (Lelystad) of 16 jaar (Marknesse, Wijster). Daardoor kunnen de momentopnames van 2002 en 2009 een breder perspectief krijgen. Met nieuw verkregen inzichten kunnen effecten van gereduceerd fosfaatgebruik op de mate van benutting van fosfaat in bouwvoor/zode en de daaronder gelegen bodemlagen worden vastgesteld. Daarmee (zie paragraaf 5.4.3.5) kan het effect van verminderd fosfaatgebruik, bv. gericht op evenwichtsbemesting, op de vermindering van de mate van fosfaatuitspoeling worden geduid.

\subsubsection{Fosfaatuitspoeling}

Metingen van fosfaatconcentraties in het bodemvocht zijn al enkele jaren niet meer uitgevoerd. Opnieuw oppakken van deze metingen in zowel de bouwland- als graslandproeven is gewenst om inzicht te krijgen in de fosfaatuitspoeling onder de verschillende opgelegde fosfaatmanagementpraktijken.

\subsubsection{Temporele variatie}

De veeljarige veldproeven laten zien dat er veel temporele variatie aanwezig is. De temporele variatie is niet direct verbonden aan opgelegde vormen van fosfaatmanagement. Bij fosforgehalten in het gewas en opbrengst gelden jaareffecten die aan klimatologische omstandigheden worden toegeschre- 
ven. Temporele variatie wordt ook aangetroffen in de trends voor grondonderzoek. Deze temporele variatie kan niet vanuit bodemprocessen verklaard worden. De temporele variatie noodzaakt tot veeljarig onderzoek om trends in wijziging van opbrengst en kwaliteit van gewassen en in fosfaatbodemfracties robuust vast te stellen.

\subsubsection{Wat kunnen de onderzoeksresultaten bijdragen aan de KRW-opgave?}

\subsubsection{Inleiding}

De resultaten van de veeljarige veldproeven geven inzicht in wat het gevolg is van een ingezet fosfaat bemestingsbeleid (fosfaatmanagement) op perceelniveau voor opbrengst, kwaliteit, beloop van de fosfaattoestand en bodemvruchtbaarheid en op beheersing van fosfaatuitspoeling.

Onderzoeksresultaten van de veeljarige veldproeven kunnen bijdragen aan de Kaderrichtlijn Water (KRW-)opgave in de betekenis dat inzicht gegeven wordt in wat de consequenties zijn van opgelegde fosfaatmanagementpraktijken op perceelniveau. Effecten op bedrijfsniveau kunnen met de resultaten van deze veldproeven berekend worden, zoals dat in hoofdstukken 3.6 en 4.4 werd uitgevoerd. Dat leidt tot inzicht in de fosfaatoverschotten (negatief, nul of positief) die bij verschillende landgebruiksvormen kunnen ontstaan. De reeksen meetgegevens van de veeljarige veldproeven reiken handvatten aan om de effecten van die overschotten op beperking van fosfaatuitspoeling te duiden.

Omdat de hydrologie van de veldproeven zelf geen onderwerp van studie is en evenmin het effect van uitgespoeld fosfaat op wijzigingen in de samenstelling van het sediment van sloten en de nalevering van fosfaat uit dit sediment, kan over deze onderwerpen - die zeer de KRW-opgave raken - geen uitsluitsel gegeven worden. Evenmin lenen de resultaten van het onderzoek zich voor onderbouwing van uitspraken op de schaal van het stroomgebied. Dit vraagt om ander, breder en multidisciplinair onderzoek.

De Kaderrichtlijn Water (KRW) streeft naar een 'goede toestand' voor alle grond- en oppervlaktewateren (rivieren, meren, overgangswateren en kustwateren) in de EU. De milieudoelstellingen van de Kaderrichtlijn Water (KRW) vormen de kern van deze EU-wetgeving, die voorziet in een duurzaam waterbeheer gebaseerd op een hoge mate van bescherming van het aquatisch milieu. Elementen van de milieudoelstellingen zijn de biologische en fysisch-chemische kwaliteit (belangrijk zijn stikstof en fosfaat) en hydromorfologische kwaliteit (stroomgebied specifiek). Belangrijke milieudoelstellingen voor oppervlaktewateren, grondwater en beschermde gebieden zijn onder meer:

- Geen achteruitgang

- Bereiken van een goede ecologische toestand (of potentieel) en een goede fysisch-chemische toestand voor oppervlaktewateren en een goede chemische en kwantitatieve toestand voor grondwater

- Geleidelijke vermindering van verontreiniging door prioritaire stoffen en geleidelijke beëindigen van lozingen van prioritaire gevaarlijke stoffen

- Ombuiging van elke significante en aanhoudende, stijgende tendens van verontreinigende stoffen in grondwater

Op de fysisch-chemische kwaliteit van oppervlakte- en grondwater oefent vermesting een negatieve invloed uit. Uit- en afspoeling vanuit landbouwgronden is de belangrijkste bron van nutriënten, stikstof en fosfaat zijn hierin de belangrijkste nutriënten. Een gebalanceerde bemesting met minimale verliezen verkleint het risico op uit- en afspoeling.

\subsubsection{Oplading en ontlading van de bodem met fosfaat}

De veldproeven hebben een bereik in fosfaatmanagement dat leidt tot een groot bereik in fosfaatoverschotten. Anno 2017 is een fosfaatgift van $240 \mathrm{~kg} \mathrm{P}_{2} \mathrm{O}_{5} /$ ha, die in de bouwlandproeven voorkomt, bevreemdend maar de opgebouwde fosfaatoverschotten van de veldproeven die hoog lijken, komen goed overeen zoals die in de afgelopen decennia opgebouwd werden in de landbouwpraktijk. In 2004 rapporteerde Schoumans (2004) cumulatieve overschotten van 2.000 tot $10.000 \mathrm{~kg} \mathrm{P}_{2} \mathrm{O}_{5}$ per ha. De cumulatieve fosfaatoverschotten van de veldproeven vallen in dit bereik. 


\section{Verdeling fosfaat over bodemlagen}

Voor fosfaatverliezen vanuit de bodem is het van belang hoe het fosfaat verdeeld is over het profiel. Fosfaat in diepere lagen vormt een groter risico voor uitspoeling dan fosfaat boven in het bodemprofiel. De fosfaatoverschotten verdelen zich over de zode of bouwvoor en daaronder gelegen bodemlagen. Dat gebeurt deels door grondbewerking, deels door biotische activiteiten (beworteling, activiteit organismen) en deels door fysisch chemische processen. De verdeling over dieper gelegen bodemlagen louter door uit- en inspoeling kan de aanrijking van de onder de zode of bouwvoor gelegen bodemlagen niet volledig verklaren. Daarvoor zijn de verhogingen van de fosfaattoestanden te hoog. Bijdrage door diep wortelende gewassen en biologische activiteit (wormen) zullen mede de fosfaattoestand van de bodemlagen onder bouwvoor/zode hebben beïnvloed.

\section{Potentie van ontlading door uitmijnen}

Eenmaal opgeladen, kan door uitmijnen (fosfaatafvoer > fosfaataanvoer) van de bodem de hoeveelheid opgeslagen fosfaat verlaagd worden. Resultaten van uitmijnen op grasland op minerale gronden (zand en klei) wijzen uit dat die ontlading van de bodem vooral in de graszode plaatsvindt. Daaronder gelegen bodemlagen worden niet armer aan fosfaat. Het is bekend dat de bodemlagen onder de zode belangrijker zijn in hun bijdrage aan fosfaatuitspoeling. Dit leidt tot de constatering dat louter uitmijnen onvoldoende bijdraagt aan het verminderen van - het risico op - fosfaatuitspoeling. Een grondbewerkingsstap waarbij ondergrond naar boven gehaald wordt, is nodig om ook het fosfaat op diepte te doen uitmijnen. Blijvend grasland op zandgrond waar in het verleden grote fosfaatoverschotten aanwezig waren, kunnen een potentieel risico blijven vormen, ook indien fosfaatbemesting afgestemd wordt op evenwichtsbemesting. Alternerend gebruik als grasland en bouwland, of graslandvernieuwing met een kerende grondbewerking, bevordert de mogelijkheden tot ontlading van de bodem van fosfaat. Dit wisselende gebruik kan de onttrekking van fosfaat op gang houden door het naar boven halen van fosfaat, door de diepere beworteling van akkerbouwgewassen en doordat nieuw grasland over het algemeen eveneens veel dieper wortelt dan blijvend grasland.

Bouwland kent veelal kerende grondbewerking ${ }^{30}$. Bovendien wortelen akkerbouwgewassen dieper dan gemaaid/begraasd gras. De potentie van akkerbouwgewassen (inclusief pas ingezaaid en niet gemaaid gras) om fosfaat in dieper gelegen bodemlagen te bereiken, is groter. Of dat daadwerkelijk ook gebeurt, hangt af van de fosfaatrijkdom van de bouwvoor. Pas bij lage fosfaattoestanden in de bovengrond zijn er aanwijzingen dat fosfaat uit de ondergrond benut wordt (dit onderzoek).

Hoewel de gegevens daarover nog beperkt zijn, blijkt dat de bodemtesten duidelijke indicaties geven dat makkelijk en gewas-beschikbaar fosfaat bij evenwichtsbemesting relatief afneemt en slecht/niet voor het gewas beschikbaar fosfaat relatief toeneemt. Het potentiële risico op fosfaatuitspoeling neemt daarbij niet af. De consequentie daarvan is dat uitmijnen via gewasafvoer steeds minder effectief wordt, omdat de opname van fosfaat door het gewas sterk afneemt in de tijd. De actuele fosfaatuitspoeling kan daarmee wel afnemen, maar het potentiële risico niet. Dat wordt namelijk geïndiceerd door de fosfaatverzadigingsgraad, en die verandert niet wezenlijk. Een afname in de fosfaatverzadiging (of P-ox) bij fosfaatverzadigde gronden zal echter leiden tot een relatief grote afname in direct beschikbaar fosfaat $\left(\mathrm{P}-\mathrm{CaCl}_{2}\right.$, dit onderzoek) en daarmee ook de fosfaatafvoer met gewas.

Bij bodems met lateraal transport, zoals veengronden, kan uitmijnen of reductie van de fosfaataanvoer tot lage of negatieve fosfaatoverschotten echter wel een snelle en positieve bijdrage aan de reductie van fosfaatuitspoeling leveren.

\section{Aanvullende meetmethoden}

Onderzoek wijst uit dat standaardbodemtesten slechts deels de effecten van evenwichtsbemesting in beeld brengen. Voor een beter begrip zijn aanvullende bodemanalyses nodig. Bij grasland zijn er aanwijzingen dat het organisch gebonden fosfaat toeneemt. Op zich is organisch gebonden fosfaat niet verloren voor het gewas. Na mineralisatie kan het fosfaat weer gewas-beschikbaar komen.

\footnotetext{
${ }^{30}$ In de nieuwe polders worden zware kleigronden diep geploegd om de bouwvoor een lager kleigehalte te geven. De vruchtbare bouwvoor wordt daardoor op $60 \mathrm{~cm}$ tot $1 \mathrm{~m}$ diepte geplaatst. Deze grondbewerkingsvorm sluit het gebruik van uitmijnen als methode voor fosfaatontlading van de bodem uit.
} 
Mineralisatie is echter een niet stuurbaar biologisch proces en seizoensinvloeden hebben hun invloed. Deze bijdrage uit mineralisatie is niet goed bekend en ook niet goed voorspelbaar.

Verrassend is de waarneming dat er tussen de kalkrijke zavels te Lelystad en Marknesse onder bouwland een groot verschil bestaat in de fosfaatconcentratie in bodemvocht bij een gelijke fractie desorbeerbaar fosfaat (resultaten cumulatieve Pi-methode). Een verkennend onderzoek naar het effect van actieve kalk (data niet gegeven) op de fosforconcentratie in bodemvocht heeft echter geen uitsluitsel gegeven. Er zijn kennelijk andere factoren die een rol spelen. Om meer te kunnen zeggen over het risico voor uitspoeling in deze gronden, zal verder onderzocht moeten worden welke bodemeigenschappen invloed hebben op de fosforconcentratie in bodemvocht. Herhaling van de profielbemonsteringen kan inzicht vergroten in de omzetting van residuair meststof fosfaat in fosfaatbodemfracties en vice versa. 


\section{Literatuur}

Aarts, H.F.M.; Boer, D.J. den; Middelkoop, J.C. van; Oenema, J. 2008. Landbouwkundige gevolgen van het aanscherpen en differentiëren van fosfaatgebruiksnormen voor de melkveehouderij. Wageningen: Plant Research International (Rapport Plant Research International 166), http://edepot.wur.nl/42905.

Boer D.J. den en J.C. van Middelkoop, 1996. Verandering van de fosfaattoestand en fosfaat in diepere bodemlagen van grasland Lelystad. In: Management op Duurzame Melkveebedrijven 6 - 37-41.

Dekker, P.H.M., Ehlert, P.A.I., 2003. Extra fosfaat, weinig effect. Bodem slechte spaarpot voor fosfaat, Boerderij 88, 15: 4-6.

Dekker, P.H.M. en P.A.I. Ehlert, 2003. Fosfaatoverschotten van bouwland op perceelsniveau II. Informatieblad 398.44 november 2003. Programma's 398-1/II/III Gefinancierd door ministerie LNV, www.mestenmineralen.nl. http://edepot.wur.nl/24928.

Dekker, P.H.M. en P.A.I. Ehlert, 2005. Landbouwkundige en milieukundige gevolgen van evenwichtsbemesting met fosfaat op bouwland. Informatieblad 398.87 december 2005 Programma's 398-1/II/III Gefinancierd door ministerie LNV, www.mestenmineralen.nl. http://edepot.wur.nl/30250.

Dekker, P.H.M.; Ehlert, P.A.I. 2005. Relaties tussen fosfaatconcentraties in bodemvocht, fosfaatfracties in de bodem en fosfaatoverschot op bouwland. Informatieblad 398.87 december 2005 Programma's 398-1/II/III Gefinancierd door ministerie LNV, www.mestenmineralen.nl. http://edepot.wur.nl/31647.

Dekker, P.H.M en R. Postma, 2008. Verhoging efficiëntie fosfaatbemesting. Bureaustudie in opdracht van Productschap Akkerbouw. PPO nr. 3250061800, Praktijkonderzoek Plant \& Omgeving, Lelystad.

Dekker, Peter en Phillip Ehlert, 2008. Verlaging fosfaatnorm nu nog geen probleem. Boerderij 93 no. 27. E10-E11.

Dekker, Peter en Phillip Ehlert. 2008. Verlaging gebruiksnorm fosfaat nog geen probleem. Groenten \& Fruit week 16, 18 april 2008, 30-31.

Dekker, P.H.M., Ehlert, P.A.I. en Wijk, C.A.P. van, 2008. Gevolgen van fosfaataanvoernorm op bouwland. Lelystad, Demodagen 'mest en energie', 2005-08-24/2005-08-25 Staf Publications. https://library.wur.nl/WebQuery/wurpubs/365135.

Dekker, P.H.M. \& P.A.I. Ehlert, 2010. Opbrengsten niet onder druk: gewassen komen later op gang. Boerderij 95 (22): $22-25$.

Dijk, W. van, P.H.M. Dekker, H.F.M. ten Berge, A.L. Smit \& J.R. van der Schoot, 2007. Aanscherping van fosfaatgebruiksnormen op bouwland bij akker' en tuinbouwgewassen. Verkenning van noodzaak en mogelijkheden tot differentiatie. PPO nr. 367, Praktijkonderzoek Plant \& Omgeving, Lelystad, http://edepot.wur.nl/36084.

Dijk, Wim van en Phillip Ehlert, 2011. Langetermijneffecten fosfaatbemesting - Bodem en gewas. PPOagv. Lelystad. Staff Publications. WAY/413352, http://edepot.wur.nl/187015.

Egnér, H., Riehm, H., \& Domingo, W.R., 1960. Untersuchungen über die chemische Bodenanalyse als Grundlage für die Beurteilung des Närhstoff-zustandes der Böden, II. Chemische 
Extraktionsmethoden zur Phosphor- und Kaliumbestimmung, Kungl, Lantbr. Hdgsk. Ann. 26: 199215.

Ehlert, P.A.I., B. Amar, L. Cisse, K.W. Jaggard, A.E. Johnston, M. Kücke, \& D. Vanvyve, 2000. Maintenance fertilization and phosphorus status in four West European soils. In: O. Christen \& F. Ordon (eds.), 3rd international crops science congress 2000 ICSC. S.I. (Germany), ESA, s.a., p. 23.

Ehlert, P.A.I. \& Johnston, A.E., 2001. Chapter 4. Fate of phosphorus in soil. In: The effect of phosphate fertilizer management strategies on soil phosphorus status and crop yields in some european countries. A.E. Johnston, P.A.I. Ehlert, M. Kuecke, B. Amar, K.W. Jaggard \& C. Morel (Eds). Actes Editions, 2001. Institut Agronomique et Vétérinaire Hassan II. Rabat, Maroc. ISBN: 9981-801-49-6, 59-100.

Ehlert, P.A.I.; Wijk, C.A.P. van; Dekker, P.H.M., 2003. Fosfaatbalansen op perceelsniveau; scan van de resultaten van vier veeljarige veldproeven op bouwland. PPO, Wageningen, 2003. PPO Publ. 305.

Ehlert, P.A.I., Salm, C. van der, \& Schoumans, O.F., 2006. Long-term effect of soil of restricted use of phosphate fertilisers. The International Fertiliser Society. Proceedings No: 593.

Ehlert, P.A.I., J.C. van Middelkoop \& P.H.M. Dekker, 2006. Actualisatie van fosfaatgehalten en fosfaatafvoer van landbouwgewassen; een verkenning op basis van onderzoeksgegevens. Alterra rapport 1348, Wageningen UR, https://edepot.wur.nl/26190.

Ehlert, P.A.I., J.C. van Middelkoop, C. van der Salm en P.H.M. Dekker, 2008. Effecten van fosfaatoverschotten op gras- en bouwland op lange termijn. Stand van zaken 2007. Wageningen, Alterra, Alterra-rapport 1665.

Ehlert, P.A.I. en P.H.M. Dekker, 2008. Beschikbaarheid van fosfaat voor het gewas op lange termijn. Informatieblad mineralen en milieukwaliteit. BO-05-infoblad-22, Cluster BO-05 Mineralen en Milieukwaliteit, Gefinancierd door ministerie LNV, http://www.kennisonline.wur.nl/BO/BO-05, december 2008, http://edepot.wur.nl/1889.

Ehlert, P.A.I., P.H.M. Dekker, J.R. van der Schoot, R. Visschers, J.C. van Middelkoop, M.P. van der Maas, A.A. Pronk, A.M. van Dam, 2009. Fosforgehalten en fosfaatafvoercijfers van landbouwgewassen: eindrapportage Alterra-rapport nr. 1773, 125 blz.

Ehlert, P.A.I. en P.H.M. Dekker, 2009. Veeljarige effecten van evenwichtsbemesting. Informatieblad mineralen en milieukwaliteit. BO-05-infoblad-17 Cluster BO-05 Mineralen en Milieukwaliteit Gefinancierd door ministerie LNV http://www.kennisonline.wur.nl/BO/BO-05 april 2008. http://edepot.wur.nl/23263.

Ehlert, Phillip en Peter Dekker, 2009. Fosfaatonttrekking door landbouwgewassen. Actualisatie van fosforgehalten en fosfaatafvoercijfers. Informatieblad mineralen en milieukwaliteit. BO-05infoblad-28 maart 2009, Cluster BO-05 Mineralen en Milieukwaliteit, Gefinancierd door ministerie LNV, http://www.kennisonline.wur.nl/BO/BO-05.

Ehlert, Phillip en Peter Dekker, 2010. Evenwichtsbemesting en opbrengst. BO-12.07. infoblad nr 01. februari 2010, http://edepot.wur.nl/134539.

Ehlert, Phillip en Wim van Dijk, 2011. Fosfaattoestand en fosfaatgebruiksnormen. Stand van zaken bij veeljarige veldproeven op bouwland. BO-12.07-infoblad-42 december 2011, http://edepot.wur.nl/210964.

Ehlert, P. J.C. van Middelkoop, C. van der Salm en W. van Dijk, 2012. Project BO-12.12-001-001 Relatie fosfaatbemesting fosfaattoestand. Veeljarige fosfaatveldproeven op gras- en bouwland. Notitie, 12 september 2012 t.b.v. voorzetting van de veeljarige veldproeven. 
Ehlert Phillip, Kees van Wijk en Janjo de Haan, 2015. Evenwichtsbemesting en fosfaattoestand. Akkermagazine, februari 2015.

Ehlert Phillip, Kees van Wijk en Janjo de Haan, 2015. Fosfaattoestand vrij stabiel onder evenwichtsbemesting Akker, april, https://library.wur.nl/WebQuery/wurpubs/501167.

Ehlert Phillip, Janjo de Haan en Kees van Wijk, 2016. Aan- en afvoer van fosfaat vaak in evenwicht. Nieuwe Oogst 12: 4, 31. https://library.wur.nl/WebQuery/wurpubs/advanced/496195

Geel, W.C.A. van, H.A.G. Verstegen \& J.J. de Haan, 2011. Opbrengstvergelijking percelen Nutriënten Waterproof en praktijkpercelen. PPO nr. 428, Praktijkonderzoek Plant \& Omgeving, Lelystad, http://edepot.wur.nl/178426.

Holshof, G., 2006. Ontwikkeling P-Al-getal op het lagekostenbedrijf (1997-2005) = Development P-AL number on low-cost farm (1997-2005) Lelystad : Animal Sciences Group / Praktijkonderzoek, (PraktijkRapport / Animal Sciences Group, Praktijkonderzoek : Rundvee), http://library.wur.nl/WebQuery/wurpubs/fulltext/22520.

Houba, V.J.G., Lee, J.J., van der Lee \& Novozamsky, I., 1997. Soil Analysis Procedures. Other Procedures, Landbouwuniversiteit Wageningen.

Houba, V.J.G., Novozamsky, I., \& Temminghoff, E., 1997b. Soil Analysis Procedures. Extraction with $0,01 \mathrm{M} \mathrm{CaCl} 2$. Landbouwuniversiteit Wageningen.

Johnston, A.E., P.A.I. Ehlert, M. Kuecke, B. Amar, K.W. Jaggard, \& C. Morel, 2001. The effect of phosphate fertilizer management strategies on soil phosphorus status and crop yields in some European countries; evaluation report (1991-1996). Rabat (Morocco), Actes/Imphos.

Krimpen, M.M. van; Middelkoop, J.C. van; Sebek, L.B.J.; Jongbloed, A.W.; Hoop, D.W. de, 2010. Effect van fosforverlaging in melkveerantsoenen en varkensvoeders op fosfaatexcretie via de mest Lelystad: Wageningen UR Livestock Research, Rapport Wageningen UR Livestock Research 321, http://library.wur.nl/WebQuery/wurpubs/fulltext/134173.

Kroes, Joop, Jos van Dam, Jan Elbers, Mirjam Hack-ten Broeke, Rob Hendriks, Jantine van Middelkoop, Caroline van der Salm, Petra Stolk, Iwan Supit, Joost Wolf, 2014, Test cases Swap-Wofost; hydrology and crop growth with Swap-Wofost, Wageningen, Alterra, Alterra Report (in prep.).

Middelkoop, J.C., Salm, C. van der, Ehlert, P.A.I., André, G., Oudendag, D., Pleijter, M., 2007. Effecten van fosfaat- en stikstofoverschotten op grasland II. Animal Sciences Group. WUR. Rapport 68. https://library.wur.nl/WebQuery/wurpubs/fulltext/31974

Middelkoop, J.C. van; Salm, C. van der; Boer, D.J. den; Horst, M.M.S. ter; Chardon, W.J.; Bakker, R.F.; Schils, R.L.M.; Ehlert, P.A.I.; Schoumans, O.F. 2004. Effecten van fosfaat- en stikstofoverschotten op grasland. ASG Praktijkonderzoek (PV), Praktijkrapport Rundvee 48, http://edepot.wur.nl/42766

Middelkoop, J. C. van, C. van der Salm and P.A.I. Ehlert, 2012. Balanced phosphorus fertilization on grassland in a mixed grazing and mowing system: a 13-year field experiment. Grassland Science in Europe, Volume 17. Editors: P. Golinski, P., M. Warda, P. Stypinski, Proceedings of the 24th General Meeting of the European Grassland Federation, Lublin, Poland, 3-7 June 2012. Grassland a European resource? Proceedings of the 24th General Meeting of the European Grassland Federation, Lublin, Poland, 3-7 June 2012 Poznan: Polskie Towarzystwo akarskie (Polish Grassland Society), 577-579 http://edepot.wur.nl/247200

Middelkoop Jantine van, Caroline van der Salm en Phillip Ehlert, 2014. Impact op bodem en gewas. Vijftien jaar fosfaatevenwichtsbemesting op grasland. V-focus April: 26-27. http://edepot.wur.nl/300275 
Middelkoop Jantine van, 2014. Gevolgen van 18 jaar evenwichtsbemesting fosfaat. Veenweiden Informatie Centrum VIC. http://www.veenweiden.nl/boeren-in-de-veenweiden/gevolgen-van-18jaar-evenwichtsbemesting-fosfaat/

Middelkoop Jantine van, Phillip Ehlert en Inge Regelink, 2016. Gevolgen van fosfaatevenwichtsbemesting op fosfaattoestand van bodem en productie van grasland vallen mee. Veeteelt jaargang 33 (2016), mei nr 1.

Middelkoop Jantine van, Phillip Ehlert en Inge Regeling, 2016. Fosfaatgehalte in de bodem blijft voldoende hoog Veeteelt, 2016, Vol.33(8), pp.44-45. http://edepot.wur.nl/380977

Middelkoop, J.C., van, C. van der Salm, P.A.I. Ehlert, I.J.M. de Boer, and O. Oenema, 2016. Does balanced phosphorus fertilisation sustain high herbage yields and phosphorus contents in alternately grazed and mown pastures? Nutrient Cycling in Agroecosystems 106 (2016)1. - ISSN 1385-1314 - p. 93 - 111. http://link.springer.com/article/10.1007\%2Fs10705-016-9791-0

Middelkoop J.C. Van, Ehlert P.A.I. and Regelink I., 2016. Balanced phosphorus fertilization on grassland in a mixed grazing and mowing system on grassland; results after 18 years; In: Proceedings of the 26th General meeting of the European Grassland federation, 04-08 September 2016, Trondheim, Norway. The Multiple Roles of Grassland in the European Bioeconomy.

Oenema O en T.A. van Dijk, 1994. Fosfaatverliezen en fosfaatoverschotten in de Nederlandse Landbouw vol Deelrapport I. Min. VROM, Den Haag (1994) 102 pp. i.o.v. Min. LN\&V, VROM, V\&W, Landbouwschap en CLO's.

Prummel, J., 1974. Veranderingen in het Pw-getal in de loop van de tijd en onder invloed van de bemesting. Rapport / Instituut voor bodemvruchtbaarheid Nr. 1974, no. 9.

http://edepot.wur.nl/274787

Prummel, J., 1978. Rhekaphos-gloeifosfaat bij voorkeur in herfst of winter geven. Boerderij/ Akkerbouw - 62, 30 jan - 4 febr, http://edepot.wur.nl/250507.

Salm, C, van der, Chardon, W.J., Koopmans, G.F., Middelkoop, J.C. van \& Ehlert, P.A.I., 2009. Phytoextraction of phosphorus-enriched grassland soils. Journal of Environmental Quality 38 (2): 751-761.

Salm, C. Van der en O.F. Schoumans, 2011. Langetermijneffecten van verminderde fosfaatgiften. Wageningen, Wettelijke Onderzoekstaken Natuur \& Milieu, WOt-werkdocument 223. http://edepot.wur.nl/169061.

Salm, C. Van der., P.A.I Ehlert and J.C van Middelkoop, 2012. Long term effects of mining soil phosphorous by zero P application. Eurosoil 2012, Bari, Italy. Poster

Salm C. van der, P.A.I. Ehlert and J.C. Van Middelkoop, 2013. Changes in soil phosphorous pools on grazed grassland after 15 years of maintenance fertilization. Programme and book of abstracts, 7th International Phosphorus Workshop, IPW 7. Uppsala, Sweden, 9-13 september 2013, p 152. http://www.slu.se/PageFiles/309958/IPW7 abstract book 130911.pdf

Salm, C. van der, J. Kros and W. de Vries, 2016. Evaluation of different approaches to describe the sorption and desorption of phosphorus in soils on experimental data. Sci. Tot. Env. 571:292-306

Salm, C. van der, J.C. van Middelkoop and P.A.I. Ehlert, 2017. Changes in phosphorus pools of grasslands following 17 yrs of balanced application of manure and fertiliser. Soil use and management. Volume 33 (1), March 2017, 2-12, DOI: 10.1111/sum.12333, http://onlinelibrary.wiley.com/doi/10.1111/sum.12333/full 
Schils, René, Wim van Dijk, Jantine van Middelkoop, Jouke Oenema, Koos Verloop, Jan Huijsmans, Phillip Ehlert, Caroline van der Salm, Henk van Reuler, Peter Vreeburg, Arjan Dekking, Willem van Geel en Jan Rinze van der Schoot, 2012. Effect van mestbeleid op bodemvruchtbaarheid en gewasopbrengst. Evaluatie Meststoffenwet 2012: deelrapport ex post. Alterra-rapport 2266, 122 blz. http://edepot.wur.nl/212627

Schoumans, 2004. Inventarisatie van de fosfaatverzadiging van landbouwgronden in

Nederland. 50 pp. Alterra Rapport 730.4, https://edepot.wur.nl/26433.

Schröder, J.J., H.F.M. Aarts, M.J.C. de Bode, W. van Dijk, J.C. van Middelkoop, M.H.A. de Haan, R.L.M. Schils, G.L. Velthof and W.J. Willems, 2004. Gebruiksnormen bij verschillende landbouwkundige en milieukundige uitgangspunten. Wageningen : Plant Research International (PRI), (Rapport / Plant Research International 79), https://edepot.wur.nl/22729.

Schröder, J. \& W. van Dijk, 2017. Actualisatie van stikstof-, fosfaat- en organische stof balansen van akkerbouw- en vollegrondsgroentebedrijven. Onderzoek naar de aanpassing van gebruiksnormen in het kader van equivalente maatregelen. Rapport WPR-683. Wageningen University \& Research / Brancheorganisatie Akkerbouw, 's-Gravenhage, https://edepot.wur.nl/420236.

Schwertmann, D., 1964. Differentierung der Eisenoxide des Bodens durch photochemische Extraction mit saurer Ammoniumoxalaat-Lösung, Z. Pfl. Ern. Düngung Bdk. 105: 194-202.

Sissingh, H.A., 1971. Analytical procedure of the Pw method, used for the assessment of the phosphate status of arable soils in the Netherlands. Plant and Soil 34: 483-486.

Sissingh, H.A., 1983. Estimation of plant-available phosphates in tropical soils. A new analytical technique, Nota 235. Institute for Soil Fertility Research. Wageningen, the Netherlands.

Sonneveld, C., Ende, J. van, \& Bes, S.S., de, 1990. Estimating the chemical composition of soil solutions by obtaining saturation extracts or specific 1:2 volume extracts. Plant and Soil 122: 169-175.

Velthof, G.L., 2004. Achtergronddocument bij enkele vragen van de evaluatie Meststoffenwet 2004 Wageningen, Alterra, Alterra-rapport 730.2, http://edepot.wur.nl/42223.

Velthof, G.L., T. Koeijer, J.J. Schröder, M. Timmerman, A. Hooijboer, J. Rozemeijer, C. van Bruggen en P. Groenendijk, 2017. Effecten van het mestbeleid op landbouw en milieu. Beantwoording van ex-post vragen in het kader van de evaluatie van de Meststoffenwet, Wageningen, Wageningen Environmental Research, rapport 2782, http://edepot.wur.nl/403643.

Wijk, Kees van, Janjo de Haan \& Phillip Ehlert, 2013. Fosfaatgebruiksnorm en opbrengst. Beleidsondersteunend Onderzoek BO-20-004 Mest, Milieu en Klimaat, http://edepot.wur.nl/279526.

Wijk, C.A.P. van; Ehlert, P.A.I.; Haan, J.J. de, 2013. Fosfaatnorm verlaagt niet direct opbrengst. Boerderij/Akkerbouw 98 (2013)17. - ISSN 0169-0116 - p. 16 - 17.

Wijk, C. Van, J. de Haan, P.A.I. Ehlert, W. van den Berg, 2013. Langetermijneffecten van fosfaatbalansen op bouwland; fosfaattrappen proefveld Lelystad. Observaties op basis van het meetprogramma 1987-2011 in een proefveld Lelystad. Praktijkonderzoek Plant \& Omgeving, onderdeel van Wageningen UR Business Unit Akkerbouw, Groene Ruimte en Vollegrondsgroenten PPO Publicatienr. 549, http://edepot.wur.nl/264018.

Willems, W.J., Schoumans, O.F. en Velthof, G.L., 2004. Milieukwaliteit en verliesnormen : achtergrondrapport deelproject Milieu van de Evaluatie Meststoffenwet 2004, Bilthoven, NL: Milieu- en Natuurplanbureau http://www.pbl.nl/sites/default/files/cms/publicaties/500031002.pdf. 


\section{Bijlage 1 Toepassing van kennis uit proeven in andere projecten}

\section{Evaluatie Meststoffenwet}

Het achtergronddocument bij de Evaluatie Meststoffenwet in 2004 heeft gebruikgemaakt van gegevens van reeksen van veeljarige veldproeven waaronder die welke op bouwland waren aangelegd (Velthof, 2004). Gegevens van de profielbemonstering werden gebruikt door Willems et al. (2004). Daarnaast werden gegevens van de grasproef over bodemvochtbepalingen gepresenteerd (Middelkoop e.a., 2003).

Veranderingen in bemesting hebben een traag effect op de fosfaattoestand van de bodem. Uit Figuur B1.1 blijkt dat het (tientallen) jaren duurt, afhankelijk van de begintoestand, voordat de fosfaattoestand van een bodem stabiel is bij een jaarlijks overschot van $20 \mathrm{~kg} \mathrm{P}_{2} \mathrm{O}_{5}$ per ha per jaar (Velthof, 2004). Tevens werd gesignaleerd dat het onthouden van fosfaatbemesting niet leidt tot een directe en snelle daling van de fosfaattoestand. Dit werd geïllustreerd met gegevens van de veeljarige veldproef op bouwland te Lelystad (Velthof, 2004).

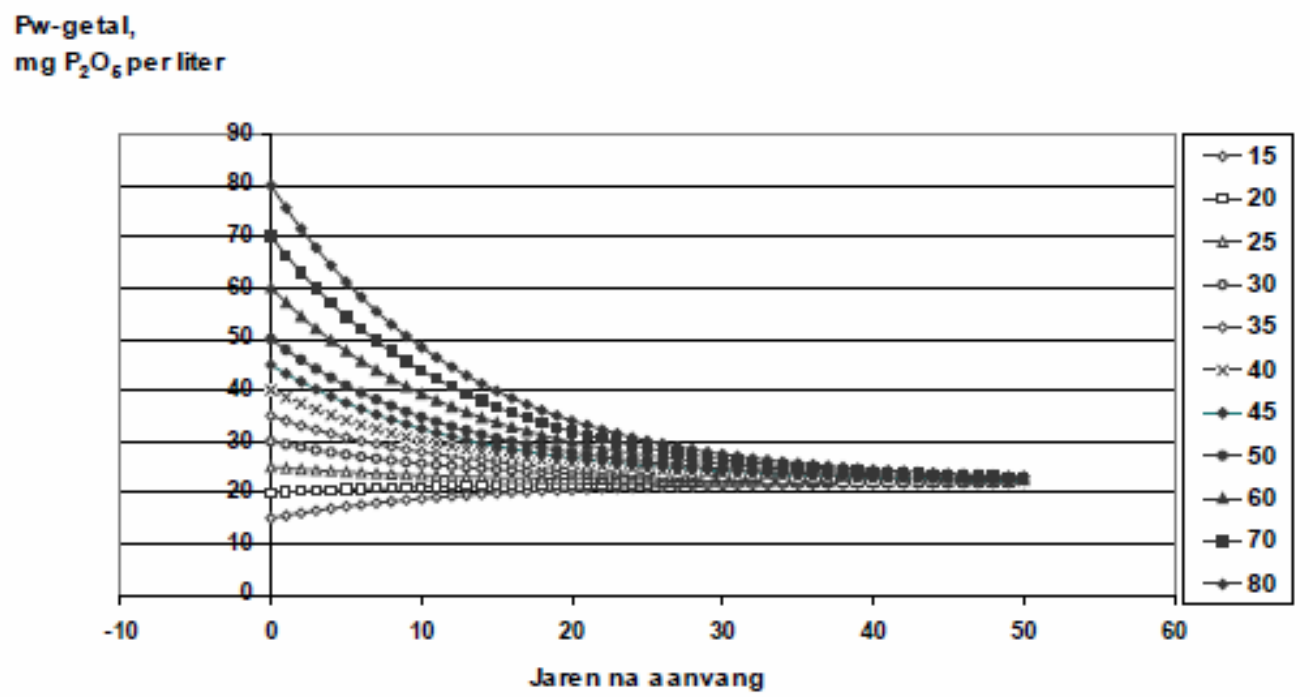

Figuur B1.1 Verloop van de fosfaattoestand gemeten als Pw-getal in $\mathrm{mg} \mathrm{P}_{2} \mathrm{O}_{5} / \mathrm{L}$ bij verschillende beginwaarden voor de fosfaattoestand bij een overschot van $20 \mathrm{~kg} \mathrm{P}_{2} \mathrm{O}_{5}$ per ha per jaar op basis van een integrale statistische analyse van 86 veeljarige veldproeven van IB, NMI, PR, PAV, CABO. De figuur geeft aan wat er het verloop is van het $P$-getal als er jaarlijks een overschot is van $20 \mathrm{~kg} P_{2} \mathrm{O}_{5}$ per ha bij verschillende beginwaarden voor het Pw-getal (Ehlert et al., 1996).

Gegevens van de veeljarige veldproeven op grasland en bouwland werden toegepast bij de Evaluatie Meststoffenwet in 2012 (Schils et al., 2012). Praktijkgegevens van het Bedrijfsinformatienet en BlggAgroXpertus, werden in samenhang gebracht met gegevens van veelal afgesloten veeljarige veldproeven. De veldproeven van dit syntheserapport waren - en zijn - de enige veeljarige fosfaatveldproeven die nog uitgevoerd worden. Overige veeljarige veldproeven zijn afgesloten. Gerapporteerd werd dat bij fosfaatevenwichtsbemesting op grasland en op zand de fosfaattoestanden

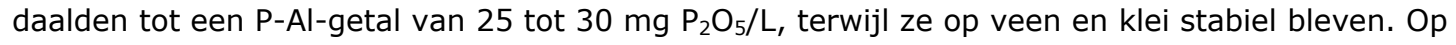
bouwland zijn de resultaten niet eenduidig. In systeemonderzoek daalde de fosfaattoestand bij evenwichtsbemesting. In veldproeven bleef de fosfaattoestand daarentegen stabiel bij evenwichtsbemesting. Mogelijk wordt deze verschillende respons verklaard door de doorgaans hogere fosfaattoestand in de uitgangssituatie van de systeemonderzoeken in vergelijking met de veldproeven. 
In de veldproeven treedt bij evenwichtsbemesting stabilisatie op bij een Pw-getal van 15 tot $20 \mathrm{mg}$ $\mathrm{P}_{2} \mathrm{O}_{5} / \mathrm{L}$ (Schils et al., 2012).

Bij de behandeling van effecten van het fosfaatgebruiksnormenstelsel op opbrengst en kwaliteit in de Evaluatie Meststoffenwet van 2016 werden de generieke bevindingen van de veeljarige veldproeven toegepast (Velthof et al., 2016). Praktijkgegevens van fosfaattoestanden op grasland en bouwland werden in samenhang gebracht met gegevens van de veeljarige veldproeven. Praktijkgegevens voor grasland lieten zien dat het P-Al-getal in de periode 2005-2015 gemiddeld stabiel was gebleven, hetgeen toegeschreven werd aan het feit dat tot 2014 gemiddeld nog steeds sprake was van een fosfaatoverschot op de bodembalans van landbouwbedrijven. De indicatoren voor mobielere fracties van fosfaat ( $\mathrm{Pw}$-getal, dat de wettelijke indicator voor bouwland is, en $\mathrm{P}-\mathrm{CaCl}_{2}$ ) lieten voor verschillende combinaties van gewas-grondsoort wel gemiddeld een daling zien in de periode 200520015, vaak bij ruime tot hoge fosfaattoestand (Velthof et al., 2015). De daling werd vooral waargenomen bij een ruime tot hoge fosfaattoestand. Waarschijnlijk wordt dit veroorzaakt door afnemende fosfaatgiften en toenemende gewasopbrengsten. De resultaten van de veeljarige veldproeven werden geplaatst tegen deze praktijksituatie. De resultaten (tot 2014) zoals beschreven in dit syntheserapport werden generiek beschreven en leidden tot de bevinding dat veel fosfaat wordt nageleverd. Over langere tijd, enige tientallen jaren, blijft de fosfaattoestand op een afdoende peil.

\section{Andere deskstudy's}

\section{Toepassing bij modelstudies}

Salm en Schoumans (2011) hebben door middel van een modelstudie de langetermijneffecten van verminderde fosfaatgiften onderzocht (zie ook paragraaf 5.2.3). Voor hun studie werden bij voorkeur gegevens van recente veld- en potproeven gebruikt, omdat gegevens van niet-recente proeven veelal geconditioneerd waren door lage fosfaattoestanden. Voor validatie zijn meetgegevens nodig van de verandering in de tijd door verschillen in fosfaatmanagement van de fosfaatbodembalans in combinatie met verandering in de fosfaattoestand (research en standaardpraktijk methoden). Focus bij deze studie zijn situaties geweest waarbij uitgegaan werd van een hoge fosfaattoestand waardoor vermindering van fosfaatgiften kan leiden tot een vermindering van de fosfaatuitspoeling. STONE werd als model gebruikt. De expliciete vraag naar gegevens over het verloop van specifieke fosfaatbodemfracties die met researchmethoden worden bepaald (P-totaal, $\mathrm{P}$-ox, $\mathrm{Pi}$, adsorptie en desorptie-isothermen), was beperkend bij deze studie. Het resultaat van de studie wijst uit dat het langetermijngedrag bij fosfaatontlading van de bodem (uitmijnen) redelijk gesimuleerd kan worden bij een juiste instelling van de lange-termijn-desorptieparameters. Vastgesteld werd dat in laboratoriumonderzoek en in potproeven hogere lange-termijn-desorptiesnelheden werden vastgesteld dan in de veldsituatie op bouwland. Op grasland werd geen verschil tussen laboratorium- en potproefonderzoek vastgesteld.

Deze resultaten doen vermoeden dat laboratoriumsnelheden gecorrigeerd dienen te worden voor het minder intensieve contact dat onder natuurlijke condities (veld-/potproef) plaatsvindt tussen bodem en oplossing (Salm en Schoumans, 2011). Geconcludeerd werd dat op de middellange termijn (5-10 jaar) bij dalende en negatieve fosfaatoverschotten het gedrag van fosfaat in de bodem redelijk te beschrijven is met de huidige procesformulering in STONE en de in deze studie afgeleide desorptiesnelheden. Om op nationale schaal voorspellingen te kunnen uitvoeren, is echter wel meer inzicht nodig in de omvang van de lange-termijn-desorptieparameters in relatie tot bodemtype en verzadigingsgraad.

Gegevens van de grasproef werden door Salm et al. (2016) gebruikt om een vijftal modellen onderling te vergelijken. Daarvoor werden onder andere gegevens van de grasproef gebruikt. Het valt buiten het bestek van dit syntheserapport om de mechanistische beschrijvingen hier te behandelen. In het algemeen simuleren de onderling vergeleken modellen de opbouw van de fosfaattoestand bij een fosfaatoverschot redelijk tot goed. Lagere aanvoer van fosfaat dan de fosfaatafvoer werd minder goed gesimuleerd. Simulaties voor de zandgrond waren beter dan die voor de kleigrond en veen. De basisgegevens van de grasproef reiken echter een verantwoord handvat aan om dergelijke modelstudies uit te voeren. 


\section{Aanscherping gebruiksnormen en verhoging efficiëntie fosfaatbemesting}

De deskstudy van Dekker en Postma (2008) onderzocht of de verlaging van de fosfaatgiften in de uitvoeringspraktijk op akkerbouw naar fosfaatgebruiksnormen opgevangen kan worden door verhoging van de efficiëntie van de fosfaatbemesting. Daarbij werd gebruikgemaakt van gegevens van de veeljarige fosfaattoestandenveldproef op bouwland te Lelystad in samenhang met uitgangspunten van het in 2007 geldende bemestingsadvies voor fosfaat. In deze deskstudy werd, op basis van de veldproefgegevens te Lelystad, ervan uitgegaan dat voor het handhaven van een bepaalde toestand, gemiddeld over het bedrijf de fosfaatafvoer moet worden gecompenseerd plus ongeveer $20 \mathrm{~kg} \mathrm{P}_{2} \mathrm{O}_{5} / \mathrm{ha}$ voor de 'onvermijdbare verliezen'. Een gebruiksnorm van $80 \mathrm{~kg} \mathrm{P}_{2} \mathrm{O}_{5} / \mathrm{ha}$ of hoger hoeft gemiddeld genomen geen probleem op te leveren (Dekker en Postma, 2008). Zeker als men in ogenschouw neemt dat de gemiddelde fosfaattoestand van de grond reeds vrij hoog tot hoog is.

Gegevens van de veeljarige veldproeven op bouwland werden door Van Dijk et al. (2007) gebruikt bij hun CDM-studie over aanscherping van fosfaatgebruiksnormen op bouwland bij akker- en tuinbouwgewassen in het kader van een verkenning van noodzaak en mogelijkheden tot differentiatie. Gevolgen van aanscherping van fosfaatgebruiksnormen werden in werkelijkheid als gering aangemerkt. Bij bedrijven met meer dan 50\% fosfaatbehoeftige gewassen (gewasgroep 0 en 1 van de adviesbasis) kunnen derving ondervinden bij een Pw-getal lager dan 35 of 40. Deze bedrijven werden aangemerkt als baat hebbend bij differentiatie.

Bij een vergelijkbare CDM-studie over aanscherping van fosfaatgebruiksnormen op grasland werden onder andere de gegevens van de grasproef toegepast (Aarts et al., 2008). Eén conclusie, die mede gebaseerd is op de resultaten van de grasproef, is dat de eerste tien jaar na invoering van evenwichtsbemesting een negatieve invloed hebben op de opbrengst, maar geen invloed op de veegezondheid. Gewezen werd op de traag verlopende bodemprocessen. Lange reeksen werden nodig gevonden om betrouwbaardere beelden te verkrijgen.

\section{Actualisatie fosfaatafvoercijfers}

Voor actualisaties van P-afvoercijfers zijn de resultaten van de gras- en bouwlandproeven toegepast (Ehlert et al., 2006; Ehlert et al., 2009). 
Wageningen Environmental Research Postbus 47

6700 AA Wageningen

T 0317480700

www.wur.nl/environmental-research

Wageningen Environmental Research Rapport 2906

ISSN 1566-7197
De missie van Wageningen University \& Research is 'To explore the potential of nature to improve the quality of life'. Binnen Wageningen University \& Research bundelen Wageningen University en gespecialiseerde onderzoeksinstituten van Stichting Wageningen Research hun krachten om bij te dragen aan de oplossing van belangrijke vragen in het domein van gezonde voeding en leefomgeving. Met ongeveer 30 vestigingen, 5.000 medewerkers en 10.000 studenten behoort Wageningen University \& Research wereldwijd tot de aansprekende kennisinstellingen binnen haar domein. De integrale benadering van de vraagstukken en de samenwerking tussen verschillende disciplines vormen het hart van de unieke Wageningen aanpak. 



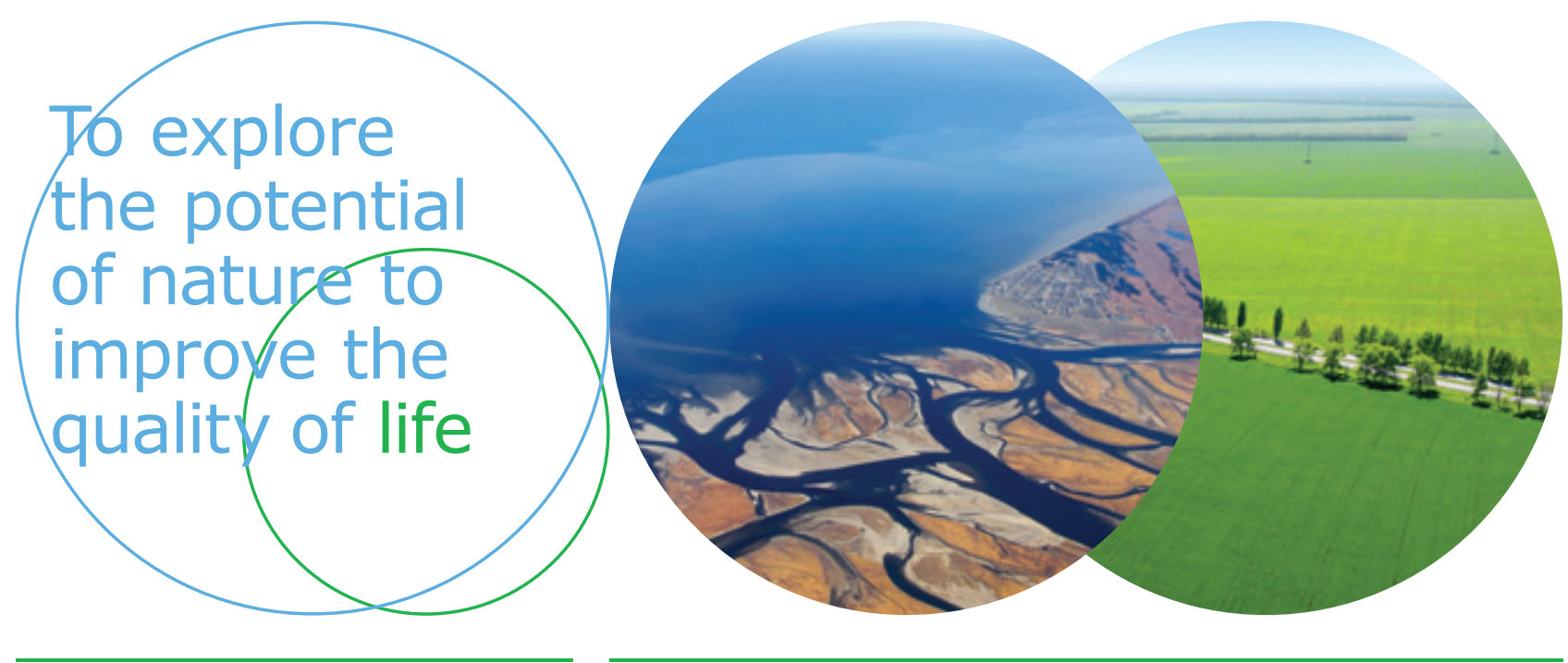

Wageningen Environmental Research Postbus 47

$6700 \mathrm{AB}$ Wageningen

T 317480700

www.wur.nl/environmental-research

Rapport 2906

ISSN 1566-7197
De missie van Wageningen University \& Research is 'To explore the potential of nature to improve the quality of life'. Binnen Wageningen University \& Research bundelen Wageningen University en gespecialiseerde onderzoeksinstituten van Stichting Wageningen Research hun krachten om bij te dragen aan de oplossing van belangrijke vragen in het domein van gezonde voeding en leefomgeving. Met ongeveer 30 vestigingen, 5.000 medewerkers en 10.000 studenten behoort Wageningen University \& Research wereldwijd tot de aansprekende kennisinstellingen binnen haar domein. De integrale benadering van de vraagstukken en de samenwerking tussen verschillende disciplines vormen het hart van de unieke Wageningen aanpak. 